$$
\text { UNIVERSIDADE DE SÃO PAULO }
$$

FACULDADE DE FILOSOFIA LETRAS E CIÊNCIAS HUMANAS DEPARTAMENTO DE LETRAS MODERNAS

PROGRAMA DE PÓS-GRADUAÇÃO EM LÍNGUA ESPANHOLA

E LITERATURAS ESPANHOLA E HISPANO-AMERICANA

EDUARDO FAVA RUBIO

O crime e as transgressões da letra:

o gênero policial em Juan José Saer e Ricardo Piglia

São Paulo

2014 


\begin{abstract}
UNIVERSIDADE DE SÃO PAULO
FACULDADE DE FILOSOFIA LETRAS E CIÊNCIAS HUMANAS DEPARTAMENTO DE LETRAS MODERNAS

PROGRAMA DE PÓS-GRADUAÇÃO EM LÍNGUA ESPANHOLA

E LITERATURAS ESPANHOLA E HISPANO-AMERICANA
\end{abstract}

\title{
$O$ crime e as transgressões da letra: o gênero policial em Juan José Saer e Ricardo Piglia
}

Eduardo Fava Rubio

Tese apresentada ao Programa de Pós-graduação em Língua Espanhola e Literaturas Espanhola e Hispano-americana do Departamento de Letras Modernas da Faculdade de Filosofia, Letras e Ciências Humanas da Universidade de São Paulo, para a obtenção do título de Doutor em Letras

Orientadora: Profa. Dra. Ana Cecilia Arias Olmos

São Paulo

2014 


\section{Eduardo Fava Rubio}

O crime e as transgressões da letra: o gênero policial em Juan José Saer e Ricardo Piglia

Tese apresentada à Faculdade de Filosofia, Letras e Ciências Humanas da Universidade de São Paulo, para a obtenção do título de Doutor em Letras.

Área de Concentração: Língua Espanhola e

Literaturas Espanhola e Hispano-americana

Aprovado em:

Banca examinadora

Prof. Dr.

Instituição:

Assinatura:

Prof. Dr.

Instituição:

Assinatura:

Prof. Dr.

Instituição:

Assinatura:

Prof. Dr.

Instituição:

Assinatura:

Prof. Dr.

Instituição:

Assinatura: 


\section{AGRADECIMENTOS}

A Tatiana, pelo amor e a cumplicidade, sem os quais eu nada faria.

Aos meus pais, Artimir e Nair, e ao meu irmão, Mauricio, por tudo que representaram para que eu pudesse construir o meu caminho.

Ao Abu, meu velho amigo, simplesmente por ser meu amigo, sempre.

A minha vizinha Isabel, amiga no mundo das letras, que de um quartinho mágico tirou muitos livros que me ajudaram na construção desta tese.

Ao professor Marcos Piason Natali, que, através da leitura do meu relatório e de sua participação em minha banca de qualificação, contribuiu decisivamente a que minha pesquisa tomasse o rumo que resultou nesta tese.

Ao professor Júlio Pimentel Pinto, que, além de participar de minha banca de qualificação, me mostrou, em suas aulas, novos caminhos no vasto mundo do gênero policial e novas possibilidades para trilhá-los.

Aos professores Pablo Gasparini e Rafael Gutiérrez Giraldo pelas aulas instigantes na pósgraduação e por toda a gentileza e atenção em me atender e ajudar fora delas.

A Ana Cecilia Olmos, pela orientação que não se impunha nem me abandonava, pelo diálogo que sempre soube ouvir mesmo minhas mais disparatadas ideias, pelos alertas sobre todos os riscos no caminho, deixando-me livre para corrê-los. Por uma orientação, enfim, que acho que foi como todas deveriam ser.

Por fim, ao professor Mario González, sempre presente com carinho em minha memória. Foi seu impulso que fez com que me aventurasse pela primeira vez na pós-graduação, foi seu estímulo que fez com que eu continuasse. Sem isto, não teria chegado até aqui. 
... ele então se limitou a sorrir e a comentar com timidez que a solução do problema emanara diretamente do mistério da criação poética.

“A sombra de um pássaro", Rodolfo Walsh 


\section{RESUMO}

RUBIO, Eduardo Fava. O crime e as transgressões da letra: o gênero policial em Juan

José Saer e Ricardo Piglia. 2014. 243 f. Tese (Doutorado) - Faculdade de Filosofia, Letras e Ciências Humanas, Universidade de São Paulo, São Paulo, 2014.

Este trabalho tem por objetivo analisar as relações entre o gênero policial e os romances $L a$ pesquisa (1994), de Juan José Saer, e Plata quemada (1997), de Ricardo Piglia. Inseridos nas poéticas singulares e originais de seus autores, ambos os textos refletem, por um lado, as práxis narrativas que tanto Saer quanto Piglia já vinham desenvolvendo havia vários anos quando da publicação dos livros, nos anos noventa. Por outro lado, a leitura dos romances sob a perspectiva das narrativas policiais, frequentemente associadas a uma literatura popular ou de massas, leva à indagação de se e como é possível o desenvolvimento de uma escrita mais complexa e ambiciosa esteticamente em diálogo com as convenções que, em princípio, caracterizam o gênero literário. A partir desta questão, a hipótese de leitura se concentrará no conceito de transgressão dentro da literatura, partindo da ideia de Michel Foucault desenvolvida no ensaio "Prefacio a la transgresión". A transgressão pensada na escrita de $L a$ pesquisa e Plata quemada, então, pode consistir em um gesto que, ao franquear os limites genéricos, não só reconfigura as poéticas de Saer e Piglia, como também repensa o conceito de gênero policial, bem como a relação dos dois escritores com o contexto cultural em que desenvolvem suas obras.

Palavras-chave: literatura argentina; gêneros literários; narrativa policial; Juan José Saer; Ricardo Piglia. 


\section{ABSTRACT}

RUBIO, Eduardo Fava. Crime and literature transgressions: crime fiction in the works of Juan José Saer and Ricardo Piglia. 2014. 243 f. Thesis (Doctorate) - Faculdade de Filosofia, Letras e Ciências Humanas, Universidade de São Paulo, São Paulo, 2014.

This study aims to analyze the relations between crime fiction - as a literary genre - and the novels La pesquisa [The investigation] (1994), by Juan José Saer, and Plata quemada [Burnt money] (1997), by Ricardo Piglia. Inserted into their author's unique and original poetics, both texts reflect, on the one hand, the narrative praxis that both Saer and Piglia had already been developing for several years when the books were published in the nineties. On the other hand, the reading of the novels from the perspective of crime fiction, a genre often associated with popular or mass literature, leads to the question of how is it possible to develop a more complex and ambitious writing, aesthetically speaking, in dialog with the conventions that, in principle, distinguish the literary genre. From this point on, the hypothesis of reading will focus on the concept of transgression in literature, as it is developed by Michel Foucault in his essay "Prefacio a la transgresión" ["A Preface to Transgression"]. Back to the way La pesquisa and Plata quemada are conceived, the transgression can be figured out as a gesture that, by crossing the genre limits, not only reconfigure the way the narrative of Saer and Piglia could be read, but also rethink the crime fiction as a genre and the relations of both authors with the cultural context in which they develop their works.

Key words: argentine literature; literary genres; crime fiction; Juan José Saer; Ricardo Piglia. 


\section{RESUMEN}

RUBIO, Eduardo Fava. El crimen y las transgresiones de la letra: el género policíaco en Juan José Saer y Ricardo Piglia. 2014. 243 f. Tesis (Doctorado) - Faculdade de Filosofia, Letras e Ciências Humanas, Universidade de São Paulo, São Paulo, 2014.

Este trabajo tiene por objetivo analizar las relaciones entre el género policíaco y las novelas La pesquisa (1994), de Juan José Saer, y Plata quemada (1997), de Ricardo Piglia. Insertadas en las poéticas singulares y originales de sus autores, ambos los textos reflejan, por un lado, las praxis narrativas que tanto Saer como Piglia ya venían desarrollando había varios años cuando de la publicación de los libros en los años noventa. Por otro lado, la lectura de las novelas bajo la perspectiva de las narrativas policíacas, frecuentemente asociadas a una literatura popular o de masas, lleva a la indagación sobre cómo es posible, si de hecho lo es, el desarrollo de una escrita más compleja y ambiciosa estéticamente en diálogo con las convenciones que, en principio, caracterizan al género literario. A partir de esta cuestión, la hipótesis de lectura se concentrará en el concepto de transgresión dentro de la literatura, partiendo de la idea de Michel Foucault desarrollada en el ensayo "Prefacio a la transgresión". La transgresión pensada en la escrita de La pesquisa y Plata quemada, entonces, puede consistir en un gesto que, al cruzar los límites genéricos, no solamente reconfigura las poéticas de Saer y Piglia, como también repiensa el concepto de género y la relación de de los dos escritores con el contexto cultural en que desarrollan sus obras.

Palabras clave: literatura argentina; géneros literarios; narrativa policíaca; Juan José Saer; Ricardo Piglia. 


\section{SUMÁRIO}

Introdução 99

1. Juan José Saer e La pesquisa 21

1.1. A narrativa "de Pichón” 22

1.2. Um protonarrador saeriano 36

1.3. A narrativa de La pesquisa

1.4. La pesquisa como narrativa policial 67

2. Ricardo Piglia e Plata quemada 78

2.1. Quem narra Plata quemada? 79

2.2. As citações como narrativa $\quad 97$

2.3. A colagem de gêneros em Plata quemada 117

3. Literaturas em contato 147

3.1. Limites e transgressões 148

3.2. O gênero e as formas da narrativa 166

3.3. Saer e Piglia em uma tradição literária 181

$\begin{array}{lr}\text { Considerações finais } & 220\end{array}$

$\begin{array}{ll}\text { Referências } & 223\end{array}$ 


\section{Introdução}

No ensaio "De parásitos, mutaciones y plagas" (2008, p. 23-37), o mexicano Jorge Volpi aborda o romance como uma das mutações da ficção. Em uma analogia com as ideias evolutivas de Darwin, Volpi trata esta espécie de narrativa como um ser vivo que busca se adaptar ao meio em que vive para sobreviver e que está sujeito a mutações, catástrofes e até à extinção. Outra característica dos romances seria sua condição de parasita, que infectaria o leitor com as ideias - ou memes - inoculadas pelo escritor. Neste contexto, haveria uma competição - natural e saudável, até - entre os romances pela sobrevivência entre os leitores, com a disseminação de seus memes da melhor e mais ampla maneira possível. Os problemas seriam os romances "praga" - Volpi cita nominalmente $O$ código Da Vinci, de Dan Brown que se multiplicam sem controle e que, ainda que inócuos - com baixíssima capacidade de inocular novas ideias -, prejudicam enormemente o "ecossistema literário". Com sua voracidade inesgotável no mercado editorial, o "romance praga" poderia se tornar um predador invencível para outras obras de maior ambição artística - estas, com alta capacidade de "infectar" leitores com novas ideias, mas frágeis no contexto da indústria cultural. Para que o romance complexo, problematizado, original e ousado em sua concepção, possa continuar existindo, então, ele precisa adotar táticas de sobrevivência. Para Volpi, o trabalho com os gêneros populares ou massivos - o policial, o noir, o fantástico, o folhetim -, nas últimas décadas do século XX, significou uma "una bocanada de aire fresco" diante das experimentações formais dos anos sessenta. No entanto, o autor também constata, por outro lado, que o uso indiscriminado dos recursos do gênero pode se converter também em um peso, sendo necessária a busca de outras estratégias, constantemente - como a simbiose entre romance e ensaio. 
Pensar La pesquisa, de Juan José Saer, e Plata quemada, de Ricardo Piglia, em suas relações com o gênero policial é, então, pensar dois textos de escritores consagrados dentro do cânone literário argentino - como autores, justamente, de obras complexas, singulares e inovadoras - em suas relações com um gênero associado à cultura de massas e vinculado, muitas vezes, às repetições e às fórmulas preestabelecidas. Assim, no contexto que alegoriza Volpi, é preciso buscar o que os romances podem representar de "ar fresco" para esta forma de narrativa, ou de que forma eles podem contribuir para a sobrevivência do romance - se é que, de fato, podem - como uma arte em busca da complexidade, da profundidade e do risco dentro da literatura.

Uma hipótese de leitura dos romances neste sentido é pensá-los a partir da ideia de transgressão como procedimento de construção literária, a partir do ensaio "Prefacio a la transgresión", de Michel Foucault (1999). A noção desenvolvida pelo filósofo francês parte da ideia de que a transgressão é um ato que concerne ao limite, de que este só se constitui pelo ato que o transgride e de que aquela só existe a partir da mesma ação na qual o limite é a condição para sua existência. Pensar a transgressão do policial realizada pelos textos de Saer e Piglia, então, é pensar um movimento no qual tanto o gênero quanto as poéticas singulares dos autores se reconfiguram - e, ao fim, um movimento pelo qual sua existência se renova e se prolonga. Entretanto, antes de começar a tratar propriamente do ato de transgressão que pode estar representado em cada romance, esta introdução servirá para tentar estabelecer um modo de pensar o limite encarnado pelo gênero policial.

O conceito de gênero literário nasce, na cultura ocidental, praticamente ao mesmo tempo em que o fazer literário, na Grécia Antiga - ainda que o conceito de "literatura", propriamente dito, seja uma ideia moderna e só tenha surgido muito tempo depois da Antiguidade Clássica. Isto se dá pelo fato de que, ao se começar a refletir sobre o objeto e o fazer literário, uma das primeiras questões que surgem é a da representação literária - ou 
artística em geral. Em suma, ao refletirmos sobre a arte que se manifesta por palavras, é natural que nos perguntemos como ocorre esta manifestação e a esta reflexão se deveu o surgimento do conceito de gênero, que tratará de sistematizar - ora para o escritor, ora para o leitor; ora para servir de regra, ora para constituir o limite a ser transgredido - a manifestação literária no que tange a sua forma, a seu conteúdo e à relação entre eles.

García Berrío (1994) traça um conciso quadro da história das classificações genéricas de Platão a Benedetto Croce, do qual alguns pontos merecem ser destacados. Em primeiro lugar, deve-se destacar que a tradicional - e até hoje utilizada - classificação tripartite dos gêneros literários - lírica, épica e dramática - só se consolida de fato com Hegel, já em princípios do século XIX, curiosamente em um momento em que os sistemas genéricos começam a ser mais firmemente questionados. A partir desta constatação, nota-se que o conceito de gênero literário em diversos contextos locais e históricos sempre esteve estreitamente atrelado ao status que gozava cada produção verbal em tais contextos. Em outras palavras, e utilizando-se uma terminologia mais moderna, a classificação dos gêneros dependia do corpus tomado como produção artística e literária, separado de outras produções verbais, como as utilizadas na vida cotidiana. Por fim, se Hegel estabelece sua classificação tripartite a partir da relação dialética entre sujeito e objeto, é fato que até este momento as "regras" segundo as quais se concebem os gêneros estão longe de serem uniformes. Assim, como nota Käte Hamburger (1986), a lírica, que hoje, ao menos em português, associamos a "poesia" de uma maneira geral, curiosamente não formava parte da poiésis de Aristóteles, já que este conceito para ele se equipara ao de mímesis e ambos - aproximados a "produção" e "representação", ao "fazer", enfim - remetem a obras com personagens e ações, o que exclui a poesia lírica. Além deste exemplo, que demonstra como a classificação tripartite dos gêneros não se adapta à concepção aristotélica, nota-se também que a lógica que guiou a concepção hegeliana não foi a mesma que guiou inúmeros outros autores e tratados até o 
século XIX. Entre autores latinos, medievais, renascentistas e neoclassicistas, variam as concepções de gênero literário, tomando-se como base para a classificação não só os modos de imitação, mas os conteúdos e temas dos textos - sendo cada um adequado a tal ou qual forma literária -, a formas linguísticas específicas dentro de um mesmo modo de representação - como poemas heroicos, trágicos, ditirâmbicos ou iâmbicos, dentro de uma "lírica" mais geral - e mesmo ao tom da obra - alto, médio ou baixo. De todo modo, pode-se traçar uma história do conceito de gênero partindo da Antiguidade e chegando até fins do século XVIII como uma categoria de forte caráter prescritivo, coercitivo - as leis do gênero delimitam os limites da escritura, erigem modelos a serem seguidos e "punem" as transgressões -, e o gênero é o arcabouço inescapável que determina o "bem-fazer" das obras artísticas e literárias.

A partir do pré-romantismo, marcado pelo movimento alemão Sturm und drang, os ditames do gênero são desafiados em prol da individualidade artística e chegamos, um século depois, às propostas de simples eliminação do gênero como categoria substantiva da crítica literária: para Benedetto Croce, por exemplo, as obras já não se devem encaixar mais nos gêneros literários como categoria estética, servindo somente do ponto de vista utilitário como critério didático, por assim dizer, de classificação das obras e não como lei estética da composição ou critério estético do juízo (2001, p. 174). Como, mesmo vítima de ataques e questionamentos, o gênero resiste a desaparecer do vocabulário tanto da crítica especializada como do leitor comum, chegamos ao século XX procurando ainda a ideia por trás do conceito.

Hamburger (1986) concebe o gênero dentro de uma lógica da Arte Literária, possível dado que a poiésis tem uma lógica fundada na lógica da linguagem. Assim, dentro de uma lógica linguística e partindo de fundamentos teóricos linguísticos, procura abraçar a produção literária dentro de um gênero ficcional - ou mimético - e outro não-ficcional - a lírica -, além 
de formas especiais - a balada, a narração em primeira pessoa, etc - que combinam características dos gêneros primordiais.

Também com forte influência das ideias e conceitos provenientes da linguística moderna, Bakhtin analisa o problema do romance moderno dentro do sistema de gêneros. De difícil conceituação e considerado mesmo, em determinados momentos, como texto "nãoliterário", o romance para Bakhtin é sim um gênero, mas ainda em evolução, do qual não sabemos o total potencial de expressão literária e que põe em crise os sistemas de classificação genérica fechados por apresentar uma estratificação interna que o conduz ao pluriestilístico, plurilíngue e plurivocal (2002, p. 72-84).

Por fim, se chegamos ao século XXI com a ideia de gênero prescritivo praticamente enterrada - ao menos na considerada "alta literatura", já que na chamada "literatura de massas" a história pode ser diferente, como veremos mais adiante -, a reflexão sobre o conceito parece continuar pertinente e seu uso, tanto em meios mais ou menos acadêmicos como no senso comum, não mostra sinais de declínio. Busco, então, para este trabalho, três das ideias vigentes nos dias de hoje sobre o conceito - o gênero como categoria histórica, o gênero como categoria de leitura e o gênero como categoria da literatura de massas - e duas possíveis justificativas para sua vigência.

Pela primeira categoria ainda aceita modernamente para o entendimento do gênero, consideramos o conceito como uma categoria histórica, isto é, os gêneros não são mais aqueles formulados por Aristóteles ou pelos manuais de retórica e poética renascentistas, e, sim, assumem formas contemporâneas, como analisa Bakhtin a respeito do romance. Desta forma, podemos catalogar hoje como gêneros o romance, o conto, o ensaio, a autobiografia, etc. Mesmo tendo perdido muito de seu caráter prescritivo a partir do século XIX, ainda podemos considerar que se espera de um livro classificado como "romance" que siga determinadas diretrizes próprias de seu gênero: se o texto tem dez páginas, não será um 
romance; se está escrito todo em verso, tampouco. Ainda que diversos autores lancem mão de experimentalismos que dilatam as fronteiras dos gêneros, mesclando e borrando as categorias apriorísticas, tais diretrizes não desaparecem simplesmente, permanecendo como um fundo, ainda que inconsciente, da produção literária, ou servindo como base, consciente neste caso, para os experimentalismos, dilatações e mesclas. De qualquer forma, com o fim do gênero como categoria prescritiva e de juízo de valor - segundo esta perspectiva, a melhor obra seria aquela que melhor segue os ditames de seu gênero -, chega-se à categoria seguinte: o gênero como uma expectativa de leitura.

É possível afirmar que já não se concebe, salvo em casos de experimentalismos literários, o gênero, ou, melhor dizendo, um gênero como padrão a ser seguido pelo escritor como uma "camisa de força" da qual não se pode e não se deve livrar-se. Também é razoável pensar que, atualmente, não há "leis retóricas" que determinem que um romance não pode ter dez páginas e há críticos dispostos a analisar as obras de maneira bastante aberta, sem préconceitos. Entretanto, é fato que o leitor comum que compra e se dispõe a ler um romance não espera - e provavelmente não aceitará - deparar-se com um texto de dez páginas. O conceito desloca-se, então, contemporaneamente, do escritor - ou seja, da produção do texto - para o leitor - a recepção dele. Compagnon afirma sobre a pertinência teórica do conceito de gênero que: “[...] é a de funcionar como um esquema de recepção, uma competência do leitor, confirmada e/ou contestada por todo texto novo num processo dinâmico.” (2010, p. 155) Não por acaso, tal afirmação se encontra no apartado "O gênero como modelo de leitura", dentro do capítulo "O leitor" de seu $O$ demônio da teoria (2010). É claro que essa adequação da obra ao horizonte de expectativa do leitor está ligada também a questões do mercado editorial, o que nos leva à terceira categoria de gênero.

Para Daniel Link, grande parte da cultura do século XX "se reconoce como producida en relación con modelos genéricos más o menos estables y más o menos hegemónicos. En ese 
sentido los géneros funcionan como un sistema de orientaciones, expectativas y convenciones que circulan entre la industria, el texto, y el sujeto." (apud MINELLI, 2008, p. 151). A definição aqui transcende a circulação literária de ideias - entre autor, texto e leitor chegando à reflexão sobre a indústria cultural que dá suporte à literatura nos dias de hoje: os gêneros ajudam a regular as relações entre produtor, produto e consumidor. Assim, por esses deslocamentos, por essas redefinições, o conceito de gênero pode encontrar uma primeira justificativa para subsistir e, a depender da maneira como for abordado, até para revigorar-se, estabelecendo limites possíveis à transgressão inovadora.

A segunda justificativa para a sobrevida do gênero, que de nenhum modo se choca com a primeira, é a divisão, também moderna, entre uma "literatura artística" e uma "literatura de massa". Ana María Amar Sánchez, em "Vínculos, usos y traiciones. La cuestión teórica" (2000) faz uma interessante discussão sobre a conceituação de "alta literatura" ou "literatura artística" e "baixa literatura" ou "literatura de massa ou popular", ressaltando a ideia presente na citação de Chartier que abre o texto: "La cultura popular es una categoría académica" (p. 11). Em outras palavras, a autora aponta as dificuldades em se definir e estabelecer as relações entre culturas "alta" e "baixa", destacando também como são maioria os estudos em torno dos efeitos ideológicos das formulas narrativas da literatura popular ou de massa e raros os que se dedicam a estudar as relações desta com a denominada "alta cultura". Em resumo, vê-se o quão externas à literatura em si podem ser as categorizações - muitas vezes feitas sobre bases ideológicas - que rebaixam determinadas obras, autores e gêneros em relação ao cânon da alta cultura - cânon este que muitas obras, a princípio marginais, passam a ocupar com o tempo, como nos casos das de Roberto Arlt e Manuel Puig, citados por Amar Sánchez.

Surge então uma problemática básica, aceitando-se o gênero - e de agora em diante trataremos especificamente do gênero policial - nas condições estabelecidas acima, ou seja, 
como "categoria histórica", como "modelo de leitura" e como "modelo de produção e consumo" da indústria cultural de literatura de massa. É possível que escritores como Saer ou Piglia, autores de uma literatura mais densa esteticamente que problematiza a própria literatura e suas questões internas, ligados ao cânone da "alta cultura" e reconhecidos por ela, transitem pelo gênero policial mantendo a coerência que é marca de toda sua produção? Indo além, e já trilhando um dos caminhos para a resposta do problema: como se pode fazer literatura - como arte, não como entretenimento - sem tratar da questão do gênero, quando, por exemplo, na Argentina de Saer e Piglia abundam exemplos de escritores de "grande literatura" - Jorge Luis Borges, Roberto Arlt, Julio Cortázar, Rodolfo Walsh - que tratam, de um modo ou de outro, o gênero policial em obras de grande alcance artístico?

Se a obra de arte singular e complexa, a obra literária com pretensões artísticas, não parece se enquadrar na noção de gênero, tal como o definimos modernamente, a obra literária de entretenimento adere-se firmemente a uma série de rígidas regras e procedimentos que, no fim das contas, garantem seu valor como literatura de massa. Nas palavras de Todorov, “a obra-prima da literatura de massa é precisamente o livro que melhor se inscreve em seu gênero" (2003a, p. 65). Claro que, aqui, utiliza-se a noção de gênero como categoria da literatura de massas, inserido na lógica da indústria cultural de produção-produto-consumo. Como vimos, entretanto, que o gênero literário pode ser entendido contemporaneamente também como "categoria histórica" ou como "categoria de leitura", vale a pergunta se tal consideração pode ser aplicada do mesmo modo ao gênero policial.

Quanto à classificação do gênero policial como categoria histórica, não parece haver grandes problemas. A despeito de diversos precursores diferentes apontados por inúmeros autores, é praticamente um consenso a constatação de Edgar Allan Poe como o fundador do gênero a partir, especialmente, de seus três contos "Os crimes da Rua Morgue", o "O mistério de Marie Rogêt” e “A carta roubada”, de 1841, 1842 e 1844, respectivamente. Assim, situa-se 
o policial como um gênero essencialmente moderno e, mais, surgido de um contexto histórico moderno bastante específico: o crescimento das metrópoles europeias - Londres e Paris, mais propriamente -, a consolidação da sociedade burguesa e os problemas ideológicos, de ordem e de criminalidade surgidos nos embates de classe surgidos neste processo, como apontam, por exemplo, Ginzburg (2011) e Mandel (1998). A relação da literatura policial com o contexto histórico também pode ser estendida, posteriormente, com o fenômeno do hardboiled ou do “romance negro" na época da Grande Depressão norte-americana ou com a derivação do romance de espionagem na época da Guerra Fria. Em suma, o policial se constitui como gênero literário moderno e em relação a processos históricos típicos também da modernidade. Assim, a adequação restrita a um modelo genérico que garante o valor da obra dentro da lógica da cultura de massa é posta em cheque pelas próprias transformações que o modelo vai sofrendo em contextos históricos diferentes. No caso do policial, a "fórmula" de Poe ainda subsiste em Conan Doyle - a narrativa de enigma -, mas o gênero encontra um novo modelo nas narrativas de Dashiell Hammett e Raymond Chandler - o hardboiled -, por exemplo. Ou seja, no gênero concebido como categoria histórica as transgressões aos modelos não são, de modo algum, indesejadas. Ao contrário, cada contexto histórico estabelecerá seus gêneros literários, muitas vezes surgidos da infidelidade aos modelos genéricos de contextos históricos anteriores.

Já a consideração do gênero policial como categoria de leitura pode levar a considerações mais complexas. Em princípio, é necessário separar a figura do "leitor" da do “consumidor de livros”, já que dentro da lógica da indústria cultural, como foi apontado por Todorov, a este devem ser oferecidas obras rigidamente atreladas aos modelos préestabelecidos por esta mesma indústria e neste procedimento reside o valor da obra - valor entendido, claro, mais no sentido de produto do que no de obra artística. O que seria então, um "leitor", considerado fora desta lógica - ou seja, um leitor não considerado como 
sinônimo simplesmente de quem consome um livro? Analisado do ponto de vista do gênero, como o faz Compagnon, pode-se conceber o leitor como o ente ao qual se atribui uma capacidade de interagir com a obra no processo literário. Assim, o leitor é aquele que, a partir da experiência prévia com a leitura e com o mundo em geral em que vive, confronta-se com o texto gerando o amplo processo ao qual podemos chamar literatura. Esta experiência, além de subjetiva, é até certo ponto imprevisível do ponto de vista da prática da escritura. Ou seja, fora dos parâmetros da indústria cultural que busca um mercado de consumidores fiel pela satisfação de um desejo por mais do mesmo, a práxis literária do escritor que trabalha com o gênero nos seus limites e na sua problemática sempre pressupõe um leitor - ideal - mais ativo, mais contestador e mais crítico.

A escolha dos romances La pesquisa, de Juan José Saer, e Plata quemada, de Ricardo Piglia, acabou mostrando-se especialmente adequada para esta discussão. Formados nos meios acadêmicos e intelectuais dos anos 60, tanto Piglia como Saer buscam desde suas primeiras obras a realização de uma literatura reflexiva - quanto ao próprio fazer literário -, esteticamente não convencional e contestadora. Analisar suas práxis literárias ${ }^{1}$ com relação ao gênero policial, portanto, é também analisá-las com relação a reflexões muito presentes na literatura contemporânea. Se o gênero policial está tão associado a fórmulas repetitivas, alienantes e apaziguadoras, como conciliá-lo aos projetos estético-literários refinados e complexos desenvolvidos pelos escritores? Se o policial atual é uma manifestação histórica de um gênero, como ele se manifesta no processo de reflexão e atuação permanente no contexto social, ideológico e cultural, que tanto caracteriza as narrativas de Saer e Piglia, escritores conscientes da história e do momento literário e intelectual em que vivem? Se é o leitor quem pode configurar o gênero em sua interação com o texto no processo literário, como pensá-lo

\footnotetext{
${ }^{1}$ O uso da expressão "práxis literária”, neste trabalho, remeterá ao que o próprio Saer faz dela, por exemplo, em "Narrathon" (1997, p. 145-58), entendendo-a como uma prática, uma ação voluntária, consciente e desejada, da qual resulta o produto artístico e seus efeitos estéticos.
} 
como leitor dentro de uma tradição de escritores argentinos que se dedicaram - e se dedicam - à literatura policial?

Além da investigação sobre como os romances de Saer e Piglia se configuram a partir de uma relação com o policial, é possível também analisar como esta relação atua na práxis narrativa de ambos os autores de maneira mais ampla. Ademais, torna-se possível, a partir disto, refletir como o gênero também pode ser repensado a partir dos processos que transgridem seus limites. Publicados em 1994 - La pesquisa - e 1997 - Plata quemada -, os dois romances que se podem classificar como policiais segundo, por exemplo, o próprio Saer (1999, p. 157-61), no caso de seu livro, e Adriana Rodríguez Pérsico, no caso do de Piglia (PÉRSICO, 2004. p. 113-21), surgem em uma época de consagração de Saer e Piglia como escritores e intelectuais na Argentina. Se estes livros surgem depois de Nadie nada nunca (1980), El entenado (1982) e Glosa (1985), no caso de Saer, e de Respiración artificial (1980), Prisión perpetua (1988) e La ciudad ausente (1992), no caso de Piglia, é lícito que se pergunte o que mudou, se algo realmente mudou, de 1980 a meados dos anos 90. Há uma concepção e uma realização literária diferente por trás de Nadie nada nunca e La pesquisa, de Respiración artificial e Plata quemada? O que este trabalho buscará, então, é também desenvolver uma reflexão sobre esta questão para alcançar uma melhor compreensão da práxis literária dos autores no conjunto de suas obras e numa perspectiva da literatura contemporânea, tomando como referencial temporal a virada do século XX para o XXI.

Assim, esta tese se desenvolverá em três capítulos. O "Capítulo 1" será dedicado ao estudo de La pesquisa, de Juan José Saer, partindo especialmente da análise das instâncias narrativas que se sobrepõem no romance. Além disto, serão abordadas as ideias de um protonarrador saeriano que perpassa as narrativas do autor, os diversos discursos que se entrelaçam no texto e de que forma todos estes fatores podem se relacionar com o gênero policial. 
De maneira análoga ao primeiro, o "Capítulo 2" se voltará à leitura de Plata quemada, de Ricardo Piglia, partindo igualmente da análise das instâncias narrativas. No caso deste romance, especificamente, será dada uma atenção especial também às citações que circulam no texto e às relações com diversos gêneros além, evidentemente, do policial.

Por fim, o "Capítulo 3" tratará de relacionar a especificidade dos dois romances aos conceitos de gênero, bem como às práxis narrativas desenvolvidas por seus autores. Para isto, partirei da reflexão sobre a ideia de transgressão, tomando por base o conceito desenvolvido por Foucault, e sobre como o gênero policial se relaciona com os diversos contextos em que surge. Em sequência, será analisado como o gênero pode se manifestar a partir de diversas concepções de narrativas - privilegiando-se, claro, as desenvolvidas por Saer e Piglia - e como as manifestações concretas dos romances se relacionam com o policial da perspectiva das tradições literárias. Neste último apartado, se procurará, dentro de uma concepção bastante ampla de tradição literária, pensar questões como os conceitos de valor e autonomia literária, as concepções teóricas sobre literatura dos dois autores e a narrativa policial na tradição literária argentina. Tudo isto para, por fim, se chegar de volta aos romances, lidos, então, de maneira mais rica e complexa, se os objetivos foram alcançados. 


\section{Capítulo 1}

\section{Juan José Saer e La pesquisa}

Inventar o real, tornar verdadeira uma vida falsa, ou, mais relevante ainda, falsa uma vida verdadeira, era uma bela tarefa para um escritor.

"Romance negro", Rubem Fonseca

O romance La pesquisa traz em seu primeiro capítulo uma história que poderíamos classificar como pertencente ao gênero policial: um policial parisiense investiga uma série de assassinatos de anciãs ocorridos na capital francesa. O segundo capítulo, que parece quase totalmente desconectado do primeiro, a não ser por referências sutis e vagas, se desenvolve, por sua vez, dentro do tradicional universo saeriano e narra episódios bastante triviais de uma viagem de Pichón Garay, argentino que vive agora em Paris, à sua cidade natal em Santa Fé e o encontro com o velho amigo Carlos Tomatis e o jovem Marcelo Soldi, a quem acaba de conhecer - ambos personagens de outras narrativas do autor. Por fim, o terceiro e último capítulo dá conta de entrelaçar as duas histórias, pondo-se em evidência a narração em abismo: a narrativa policial do primeiro capítulo é urdida por Pichón, personagem da narrativa tradicional do universo saeriano que é apresentada no segundo capítulo.

Publicado em 1994, La pesquisa vem à luz em um momento em que Juan José Saer tem já sua obra consagrada no meio literário argentino, além de uma escritura mais do que reconhecida em sua originalidade e singularidade ${ }^{2}$. Assim, um possível estranhamento inicial,

\footnotetext{
${ }^{2}$ Como exemplo, María Teresa Gramuglio, em texto datado de 1984 e publicado originalmente em 1986 como epílogo da antologia Juan José Saer por Juan José Saer, afirma, a respeito das perguntas sobre o lugar que ocupa a obra de um escritor no mundo, que "[las grandes tradiciones de la cultura occidental] pueden volver obstinadamente cuando se considera una obra como la de Saer, a la que no parece exagerado atribuir una tendencia a lo clásico, entendiendo aquí por clásico aquello que puede perdurar, como diría Habermas, justamente por ser moderno de un modo auténtico, es decir, por estar fuertemente enraizado en el tiempo en que se vive". (REALES; PREMAT; MONDRAGÓN, 2010, p. 35)
} 
por parte dos leitores mais ou menos acostumados à obra de Saer, de ler um texto seu consagrado a um gênero tradicionalmente associado à "literatura de massa" como o policial, só começa a desaparecer no segundo capítulo, quando a narrativa se desloca para o cenário habitual de quase todas as outras narrativas do autor: a província de Santa Fe. O caráter previsível das narrativas de gênero cede lugar, então, a velhas questões da práxis narrativa saeriana: o problema da representação do real, o próprio status do real e do verdadeiro na narrativa e a criação de um espaço coerente para a prática narrativa, não só de um espaço geográfico - o mundo do autor -, mas de um espaço que comporte um tom, uma cadência na definição de Julio Premat (2009). Como conciliar as tradicionais questões saerianas e uma narrativa de gênero - com tudo o que o termo suscita de discussão e polêmica - alia-se então a outro problema que esta narrativa representa por si: o de relacionar-se com um gênero associado à literatura de massas e, ao mesmo tempo, pertencer à obra de um escritor tão crítico a essa mesma literatura. Isto parece ser o ponto de apoio de todo o romance e é o que baseará as reflexões deste capítulo.

\subsection{A narrativa "de Pichón"}

Como já mencionado, La pesquisa se inicia com uma narrativa que se poderia sem dificuldade classificar como pertencente ao gênero policial: somos, já na primeira página do romance, apresentados a Morvan, comissário encarregado do escritório especial da Brigada Criminal em Paris, encarregado da investigação de uma série de crimes. Em seguida, nos são apresentados alguns dos detalhes dos crimes: vinte e sete mulheres idosas haviam sido assassinadas (até o momento) em Paris, nas regiões do $10^{\circ} \mathrm{e}$, especialmente, do $11^{\circ}$ arrondissements, em circunstâncias aparentemente ritualísticas, o que incluía estupros (ante e post mortem) e dissecação dos corpos. O assassino, logicamente, é desconhecido e 
praticamente não deixa pistas, como convém às exigências de suspense e mistério da narrativa policial clássica. Além disso, como também se pode considerar como lugares comuns do gênero, apresenta, segundo o narrador (Pichón), “[1]a tentación clásica de desafiar a la policía” ( $\mathrm{LP}^{3}$, p. 31) e um "sentido estético”, já que para Morvan "era fácil percibir el toque personal en los veintisiete crímenes" (LP, p. 40) ${ }^{4}$.

Todos esses elementos convencionais da narrativa policial aparecem no primeiro capítulo do romance pela voz de um narrador em terceira pessoa que saberemos depois ser Pichón Garay, personagem recorrente na obra de Saer que aparece a partir do segundo capítulo. Este mesmo narrador retoma seu relato no terceiro e último capítulo do livro seguindo os passos clássicos do gênero. Há, por exemplo, o descontentamento do detetive cerebral e racionalista com a pressão burocrática de seus superiores, expressa em tom de clichê ${ }^{5}$ - segundo Morvan e seu amigo e colega de polícia Lautret, "sólo los burócratas para creer que recomendaciones y amenazas pueden cambiar el curso de los acontecimientos" (LP, p. 100) . Lança-se mão também do recurso da descrição geográfica da cidade, no passeio que o detetive faz saindo do escritório, ninho de suas ruminações sobre o caso ${ }^{6}$, e do reforço no suspense - "La inminencia de algo terrible lo agitaba", diz o narrador sobre Morvan (LP, p. 107). Por fim vem outro sangrento assassinato, o da $28^{\mathrm{a}}$ vítima, e com ele uma série de outros elementos clássicos do gênero. Aparecem a descrição da cena do crime - reforçando o "estilo" do criminoso, o "artista que había trabajado la carne" (LP, p. 118) - e as pistas - o pedacinho de papel no carpete (LP, p. 113), as duas garrafas de champanhe (p. 118-9).

\footnotetext{
${ }^{3}$ A sigla LP será usada nesta tese para as referências e citações de La pesquisa de acordo com a edição usada neste trabalho e citada na bibliografia.

${ }^{4}$ A discussão sobre o sentido estético do crime pode ser encontrada em textos desde Do assassinato como uma das belas artes, de De Quincey, a "A simples arte de matar", de Chandler. Já o criminoso que desafia propositalmente a polícia se apresenta em personagens como Moriarty, nas narrativas de Conan Doyle; Frédéric Larsan,, em $O$ mistério do quarto amarelo, de Leroux; ou Red Scharlach,, em "La muerte y la brújula", de Borges.

${ }^{5}$ Como acontece com personagens como o Comissário Maigret, nas histórias de Simenon ou o Comissário Montalbano, nas de Camilleri.

${ }^{6}$ Aqui, as andanças de Morvan por Paris (LP, p. 105-6) lembram as do personagem de "O homem da multidão" por Londres, na espécie de "protoexemplar” do gênero escrito por Poe (1986).
} 
Seguem-se as conjecturas do detetive - o quebra-cabeça de pedacinhos de papel (LP, p. 1234) -; a tentativa de definir o suspeito - "el animal que buscaba era astuto, excesivo, razonador y cruel; era violento y meticuloso" (LP, p. 129) -; e, por fim, a dedução de Morvan sobre o culpado - "el comisario Lautret era el hombre que buscaba" (LP, p. 133) -, que se mostrará logo questionável.

Até este ponto, podem-se notar as marcas necessárias de convencionalismo que conformam, a princípio, o gênero policial, especialmente enquanto produto da dita literatura de massas. São evidentes tanto os elementos principais - o crime, o detetive, o assassino misterioso -, como vários aspectos secundários, mas igualmente significativos da tradição clássica do policial - o caráter cerebral, ainda que também muitas vezes intuitivo, e pouco ativo do detetive, a brutalidade e inteligência acima da média do criminoso, a construção do suspense, as falsas pistas, as reviravoltas e a surpresa final. É significativa também, como marca convencional do gênero, a figura do narrador em terceira pessoa que relata fatos dos quais supostamente esteve relativamente próximo e dos quais sabe muitos detalhes. Vários são os fatores, portanto, que acolhem o romance dentro de uma tradição de gênero, a despeito da outra narrativa interpolada que será abordada mais adiante.

Não bastassem esses elementos, é o próprio Saer quem considera La Pesquisa um relato policial, como afirma em artigo sobre o romance publicado em La narración-objeto: “[...] el hecho de escribir un relato policial me otorgó, por el tiempo que duró la redacción, una especie de equilibrio entre la tensión de un trabajo adulto y el placer del abandono a una imaginación infantil." (1999, p. 160, grifo meu).

Se o gênero policial é assumido sem maiores problemas e até com certa satisfação por Saer, o que parece tê-lo preocupado, ainda segundo o mesmo artigo de La narración-objeto, foi como manter-se fiel ao "gênero Saer" dentro da narrativa policial (1999, p. 159-160): 
Aunque en varias de mis narraciones introduje deliberadamente ciertos elementos de novela negra, abordar de un modo directo el género policial implicaba muchos problemas [...] Consciente de todos esos problemas, el placer de escribir una novela policial debía adaptarse en primer lugar a mi propia "manera" narrativa, y en segundo término, a partir de la crisis evidente del género, buscar alguna otra forma de relato policial para la materia que tenía entre manos.

A "crise evidente do gênero" seria a tendência cada vez maior ao convencionalismo na narrativa policial e a ausência de transgressão que desestabilizaria o gênero e abriria as portas para uma narrativa mais particular? É a partir desta crise que o autor encontra a "forma" para seu romance?

\section{As fissuras na narrativa de Pichón}

O narrador do relato policial dentro de La pesquisa, que a princípio parece ter as características do narrador clássico do gênero, vai revelando aos poucos, e em uma leitura mais atenta, uma série de aspectos problemáticos que podem desestabilizar uma primeira impressão na qual sobressaiam as convenções genéricas.

No modelo clássico do policial, o que se apresenta é o relato da investigação que, por sua vez, tentaria dar conta do relato do crime. Ou seja, a narrativa policial é uma narrativa sobre outras narrativas. Na vertente clássica da narrativa de enigma isto é mais claro: seja pelos jornais, por depoimentos de testemunhas e suspeitos ou pela leitura de pistas, o que se narra é a reconstituição de uma narrativa anterior à que se lê, a narrativa do crime. Dito de outro modo, há neste tipo de policial uma trama, a do crime (que só se revela por completo no final da narrativa), há outra trama, que é a do raciocínio do detetive (muitas vezes com pouca ação de fato), e por fim, muitas vezes, a narrativa do amigo ou auxiliar do detetive que dá conta das outras duas. Exemplos deste mecanismo surgem quando lemos a narração do Dr. 
Watson sobre a investigação de Sherlock Holmes sobre um crime cometido anteriormente (Conan Doyle), o relato do amigo anônimo sobre os casos de Dupin (Edgar Allan Poe), os casos de Poirot narrados por Hastings (Agatha Christie) ou os de Nero Wolfe por Archie Goodwin (Rex Stout). O narrador da história policial de La pesquisa poderia se inserir, a princípio, nesta linhagem. O fato de não ser um amigo ou acompanhar o detetive em suas investigações, não seria necessariamente um impeditivo, já que outros detetives clássicos têm suas histórias contadas por narradores em terceira pessoa mais distanciados: exemplos são o Padre Brown (G. K. Chesterton) e Maigret (Georges Simenon). A singularidade do narrador policial de La pesquisa se apresenta, entretanto, em sua posição no romance como um todo: Pichón será, na verdade, tanto o narrador do relato policial parisiense como o personagem recorrente saeriano na narrativa que se desenvolve em Santa Fe.

Esta caracterização particular do narrador policial no romance - de todo modo, já excêntrica em relação a quaisquer dos modelos canônicos - condiciona a narrativa em si em sua relação com o gênero. Assim, por exemplo, ainda que no primeiro capítulo se monte todo um cenário clássico do policial mais canônico, a práxis narrativa saeriana transparece no que é narrado por Pichón. Nas primeiras quarenta páginas quase nada acontece: flagramos Morvan imóvel à janela, refletindo sobre os crimes, nas primeiras linhas do romance, e esta cena só se “descongela", só tem uma sequência de ação no terceiro capítulo, na página 93. Percebe-se, então, de que maneira o policial e a "maneira narrativa" de Saer podem se encontrar: em lugar de uma série de peripécias e reviravoltas na investigação - como é comum se esperar no mais tradicional do gênero - as reflexões de Morvan e do próprio narrador Pichón, ambas muitas vezes nem relacionadas diretamente com os crimes, se destacam. As ações virtualmente inexistem no primeiro capítulo e pouco se desenvolve no lapso de tempo interno ao relato de pouco mais de 24 horas, do começo à prisão de Morvan. Como o gênero se constitui de narrativas sobre narrativas, qualquer uma delas pode se constituir a partir da "maneira" 
saeriana. A narrativa de La pesquisa, com isso, participa do gênero, tomando-lhe algumas de suas premissas essenciais, sem que, no entanto pertença a ele totalmente, no sentido de se entregar a suas fórmulas mais consagradas e repetidas.

\section{Pichón entre o narrador policial e o personagem saeriano}

O narrador que dá início ao romance narrando a trama policial se revelará posteriormente como sendo um dos personagens recorrentes das narrativas e o do universo ficcional saeriano: Pichón Garay, um dos gêmeos Garay, irmão do Gato e amigo de longa data de Carlos Tomatis ${ }^{7}$. É este narrador que, se por um lado arma em seu relato um cenário condizente com as convenções do gênero policial clássico, por outro as desestabiliza na mesma intensidade. Os pontos a se analisar neste sentido - o da desestabilização das convenções do gênero - são a posição do narrador em relação ao narrado, ao receptor de seu relato e à forma que adquire seu relato.

Como já se mencionou, pouca trama ou pouca ação é, de fato, narrada no relato de Pichón: Morvan está à noite em seu escritório refletindo sobre o caso dos assassinatos; entram seus colegas para falar-lhe (muitas páginas adiante); ele sai para um passeio pela cidade e volta ao escritório onde dorme. No dia seguinte, sai para a cena do crime da $28^{\text {a }}$ vítima, almoça na rua e regressa novamente à base. Por fim, à noite, vai à casa de Mme. Mouton, onde perde a consciência e supostamente entra em estado de delírio e mata sua anfitriã, sendo preso em seguida. Posteriormente, o que se narra sem maiores detalhes na trama é o rápido julgamento de Morvan e sua estada no manicômio. Com tão pouca trama, o que se narra então?

\footnotetext{
${ }^{7}$ Aqui, Saer reproduz o procedimento presente em La vida breve, de Juan Carlos Onetti, quando também um personagem intercala sua própria narrativa à principal do romance. No artigo "El soñador discreto" (2006, p. 208), sobre Onetti, o próprio Saer o chama de "un espacio imaginario a la segunda potencia".
} 
Pichón, como personagem de Saer, parece então adquirir traços do estilo de seu criador: o que narra é mais a situação de Morvan, um personagem que parece congelado em um presente eterno, que suas ações. Este estado presente do detetive se constrói então com múltiplos elementos da narrativa: as descrições de seu caráter, os sonhos recorrentes, a separação da mulher, o relacionamento com os colegas, sua constituição "histórico-cultural" como europeu e francês de determinada classe social, a relação com o pai, a criação pela avó, a figura da mãe que o abandonou. É, entretanto, desta narrativa, bastante identificada com a práxis saeriana, que pouco narra ações e muito tenta dar conta de uma realidade presente, espessa, saturada e ao mesmo tempo inacessível, que brotam também pistas de uma trama policial.

Como nos exemplos mais tradicionais e convencionais do gênero, Pichón também tem reservado para o final de seu relato a (supostamente) surpreendente revelação do criminoso e a elucidação do crime através das "pistas" apresentadas até então. Assim, o sentimento de proximidade de Morvan com o assassino se justifica e seus sonhos revelam seu alegado significado dentro da mente do criminoso. A cidade fantasmática do sonho, em sua semelhança com a cidade real, dá o indício de que o sonho passara a ser alucinação. As figuras mitológicas estampadas nas notas de dinheiro passam a ser relevantes como monstros femininos e híbridos (Cila, Caríbdis, Górgona, Quimera), em relação com o ódio do assassino pelas mulheres idosas, sua personalidade cindida e o velho livro de mitologia do detetive. Detalhes na narração ganham novo significado: ao descrever a ação do assassino, por exemplo, o narrador fala em "noche de pesadilla", "sombra sin límites" (LP, p. 40), "sueños insensatos" (LP, p. 45) e "una especie de trance hipnótico" (LP, p. 129), ao passo que os sonhos do próprio Morvan, a princípio descritos como "curiosos" (LP, p. 25), passam a ser caracterizados como "inquietantes", passíveis de "problemas de legibilidad", uma "especie de trance" (LP, p. 108) que lhe dava a impressão de que "se había pasado a otro mundo" (LP, p. 
109). Neste contexto, todas as referências psicanalíticas às sombras, ao sótão (da consciência), à pulsão, ao duplo inerente ao ser humano servirão como base às explicações dadas pelos psiquiatras ao final (LP, p. 182-8). Estas referências estão espalhadas ao longo da narrativa de Pichón, mas pode-se considerar que aparecem condensadas de maneira mais exemplar em uma passagem: "la sombra que venía persiguiendo desde hacía tantos meses, inmediata pero inasible, igual que su propia sombra, saliendo de su desván recóndito y oscuro, movida por un impulso repetitivo y funesto, como una sierra sinfín puesta en marcha desde el origen del tiempo". (LP, p. 110). Mas a quem estão dirigidas estas pistas e referências?

Sem saber ser Pichón o narrador da trama policial no início do romance, resta ao leitor tentar situar ao menos a posição desse narrador: de onde fala, a quem se dirige, que relação guarda com a matéria narrada. Assim, se o narrador que se mostra no princípio onisciente e narrando em terceira pessoa se ajusta ao cânone do gênero policial, também são os detalhes da narrativa que problematizarão esta posição.

O narrador do relato do assassinato das velhinhas parisienses afirma e tenta legitimar sua posição e autoridade para contar a história ao mesmo tempo em que não se expõe ou revela de onde narra, como se nota em diversas passagens: "Les aseguro que...", "como les decía” (LP, p. 26), “debo señalar" (LP, p. 28), "Ya me han venido oyendo...” (LP, p. 30), "les avisé que se agarraran bien” (LP, p. 31), “ya les hablaré de esto más adelante [...] Pero no quiero anticiparme. Por ahora, lo que hay que saber..." (LP, p. 33), "como creo haberles dicho” (LP, p. 37), "Tendrían que haber estado allá y vivido en ese barrio como yo para darse cuenta del clima que reinaba como se dice en esos meses." (LP, p. 40). Nestas mesmas passagens, todas do primeiro capítulo do romance, percebe-se um interlocutor (na verdade um grupo de interlocutores, no plural) que também não se especifica - assim como nas passagens: “agárrense bien" (LP, p. 8) e "Ustedes se deben estar preguntando..." (LP, p. 22) -, mas que poderia ser tomado como o conjunto de leitores, em uma técnica - o narrador que se dirige ao 
leitor - que, se não é própria do gênero policial, é comum na narrativa em geral. Ao perceber, no capítulo seguinte, que o relato policial é urdido por Pichón e se destina, em uma informal conversa em um bar, a seus amigos Tomatis e Soldi, outros elementos deste mesmo relato sobressaem ou ganham novos sentidos.

A posição do narrador, a partir das revelações do segundo capítulo, faz com que a frase que abre o romance - “Allá, en cambio, en diciembre, la noche llega rápido.” (LP, p. 7) - seja repensada, tendo em vista que "ese lugar llamado París" (LP, p. 7) se contrapõe claramente a um "aqui", este lugar de onde fala o narrador, no qual, em dezembro, a noite tarda a chegar. O lugar do narrador e de origem da narrativa, revelado depois como o espaço diegético tradicional de Saer, uma Santa Fe de ficção, lhe dá sentido, em alguns aspectos e até certo ponto, ao discurso que relata a trama policial. Assim, por exemplo, muitos topônimos aparecem na narrativa de forma castelhanizada ("Bulevar Voltaire", "Arco de Triunfo", "la Sorbona”, "Plaza León Blum", "la Brigada Criminal”), ainda que outros termos permaneçam no original francês, o que poderia resultar até obscuro para o leitor, mas que o narrador Pichón, que vive em Paris - supõe que seus interlocutores - Tomatis e Soldi - possam compreender (os "arrondissement"; "La Mondaine"8).

O mesmo sentido que a narrativa cobra se entendida como um discurso próprio de um emissor específico e dirigido a destinatários específicos também transparece em outros aspectos e referências do relato, como nas descrições das velhinhas parisienses, potenciais vítimas do insano assassino - "son un elemento propio de esa ciudad, un detalle del color local, como el museo del Louvre" (LP, p. 11) -, ou nas dos detetives, protótipos do homem de seu tempo, lugar e posição histórica e social (LP, p. 94-5):

\footnotetext{
8 "La Mondaine" é oficialmente, hoje, a "Brigade de répression du proxénétisme”, espécie de "polícia de costumes" encarregada de assuntos ligados à prostituição e ao lenocínio.
} 
Sin ser físicamente parecidos [...] los cuatro hombres eran sin embargo semejantes, y sus rasgos comunes, si bien provenían de su vestimenta y de los automatismos de su profesión, se debían también a la época y a la civilización a que pertenecían [...]. Daban por sentado que pertenecían a cierta civilización, y ese hecho era para ellos indiscutible [...]

Nos dois casos, fica patente o distanciamento do narrador com relação aos personagens que descreve: as velhinhas, parte da cor local dessa cidade; os policiais, parte de uma civilização que é, para eles, um fato indiscutível.

Estabelecido o lugar de onde narra Pichón - de maneira mais evidente a partir do segundo capítulo e "cifrada" no primeiro - e delimitados os destinatários de seu relato - da mesma maneira -, poderia parecer que a forma da narrativa se estabelece somente a partir destas coordenadas. Tal pensamento, como se verá, tampouco está isento de ser problematizado no relato dos crimes.

Permeando a pouca ação da trama, como foi visto, há na narrativa de Pichón inúmeras descrições e digressões que permitem que se estabeleça o relato policial, mais que como sucessão de peripécias - do detetive, das vítimas ou do assassino -, como construção de uma situação - na qual os personagens estão como que congelados em uma cena, em um presente eterno para o qual todos os tempos confluem. Em outras palavras, Morvan se constitui menos como o detetive que investiga os crimes que ele próprio comete, e mais como o personagem de um quadro o qual todos os outros elementos da narrativa parecem ajudar a compor. Neste procedimento, o relato de Pichón por vezes se desestabiliza: apartando-se do caso informalmente contado aos amigos, aproxima-se da narrativa da qual ele próprio é personagem, iniciada somente no segundo capítulo.

Na descrição das velhinhas, além da passagem mencionada anteriormente, o narrador lança mão de inúmeras estatísticas como fatos empíricos e como maneira de dar autoridade à história: "quiero que sepan desde ya que este relato es verídico" (LP, p. 9). Por outro lado, este recurso na narrativa conduz à desumanização e à desindividualização das vítimas e 
explicita seu caráter de personagem em uma narrativa, forçando o leitor - especialmente o acostumado ao "faz de conta" e à simulação do real nas narrativas tradicionais como as do gênero policial mais convencional - a pensar, além da trama do relato, nos procedimentos de construção deste como artifício. O procedimento é reforçado, por exemplo, quando o narrador caracteriza as anciãs como "símbolo, idea, metáfora, principio" (LP, p. 11), ou quando Morvan reflete sobre "el instinto casi infalible que induce a menudo a las víctimas a asumir con facilidad, por no decir con diligencia, su papel" (LP, p. 164, grifo meu).

A ambiguidade presente no recurso de reforçar o caráter artificial da narrativa - não sabemos se dirigido a Tomatis e Soldi ou a nós, leitores, ou a todos - se repete nas referências literárias e culturais do narrador. Novamente com a marca do artifício narrativo - já que, dentro da trama, surgidas de um livro que Morvan tinha desde criança -, as referências à mitologia grega, por exemplo, se constituem como um uso de uma narrativa - a mitológica na construção de outra - a policial. A percepção deste mecanismo, também ambiguamente, pode ser destinada aos amigos de Pichón, habituados a discussões intelectuais e literárias, ou ao leitor do romance. Aqueles podem buscar a relação das referências com o enredo do relato policial que estão ouvindo, enquanto o leitor pode extrapolá-las ao romance como um todo por não dizer à obra de Saer. Saída da memória infantil do detetive, serve à narrativa de Pichón a lenda do rapto de Europa por Zeus, metamorfoseado em touro branco na ilha de Creta, expandindo seu sentido quase que infinitamente. A violência do masculino, metamorfoseado em besta, contra o feminino indefeso ilustra a sanha insana do assassino de velhinhas ao mesmo tempo em que serve ao narrador como imagem da qual pinça a figura dos plátanos para falar do inverno parisiense. Além disso, pode remeter a Luis de Góngora, que, no início de suas Soledades, lança mão da mesma lenda para situar a ação também em uma estação do ano - neste caso, a primavera ${ }^{9}$ - e remeter o leitor ao escritor espanhol cujos

\footnotetext{
9 "Era del año la estación florida / En que el mentido robador de Europa / (media luna las armas de su frente, / y el Sol todos los rayos de su pelo)". (GÓNGORA, 1998, p. 75)
} 
versos serviram de epígrafe a dois livros de Saer: o romance El limonero real $(2002)^{10}$, de 1974, e a compilação de relatos La mayor $(1982)^{11}$, de 1976. A referência, portanto, nasce da narrativa policial tecida pelo personagem Pichón ou da instância narrativa primária do romance de Saer? Destina-se a Tomatis e Soldi ou ao leitor do romance La pesquisa? Estas perguntas podem ser pertinentes ou tais distinções são impossíveis e a reflexão sobre elas aponta, na verdade, para a constituição mesma da narrativa do romance e de Saer por parte do leitor?

Um exemplo mais da exposição, por parte do narrador, do relato como relato - isto é, do relato como construção, como artifício - é a insistência, de maneira mais ou menos explícita, em mencionar o gênero policial. Em certa passagem o narrador parece escusar-se pelos aspectos convencionais da narrativa: "Esos lugares comunes - mezcla de demencia y de lógica, gusto megalómano del riesgo, insistencia dramatúrgica y topográfica - no los atribuyan por favor a la banalidad de mi relato" (LP, p. 31-2). Ao descrever o comissário Lautret, diz que "había visto tal vez demasiadas películas policiales, calcando su comportamiento sobre modelos demasiado arquetípicos" (LP, p. 35) Ao se referir ao assassino, a partir da página 37, o narrador diz inúmeras vezes "el hombre o lo que fuese", sugerindo que talvez não se tratasse de um homem. Isto, por um lado, remete à narrativa inaugural do gênero policial - "Os crimes da rua Morgue", de Poe - na qual o "criminoso" que todos pensavam ser um homem, era na verdade um orangotango - e, por outro - quando o narrador afirma que "el hombre o lo que fuese [...] se metamorfoseaba en monstruo" (LP, p. 119) - ao tópico do duplo presente na alma humana, presente, por exemplo, em $O$ médico e o monstro, de Stevenson - ainda que este não considerado normalmente como texto pertencente ao gênero policial. As autorreferências ao gênero dentro da narrativa extrapolam mesmo o

\footnotetext{
${ }^{10}$ Cuja epígrafe é tirada de uma "letrilla" sacra: "Oveja perdida ven / sobre mis hombros que soy / no sólo tu pastor soy / sino tu pasto también". (RIVERS, 1997, p.232)

11 "Pasos de un peregrino son errante", verso que abre a Dedicatória ao Duque de Béjar, também nas Soledades (GÓNGORA, 1998, p. 71).
} 
narrador, personagens ou situações, chegando ao leitor do policial, migrando do texto para o ato de leitura em si: ao ser interrogado por Mme. Mouton - a última vítima - sobre a série de crimes, a Morvan lhe parece que a anciã o faz "con un interés [...] excesivo por los aspectos macabros que parecían despertar en ella menos compasión que una especie de euforia inexplicable" (LP, p. 166). Deste modo, Mme. Mouton, que havia tomado conhecimento dos crimes pelas notícias do rádio e da televisão, comporta-se como o leitor de policiais que se excita com os crimes da ficção - cuja violência é importante atrativo que apela ao fascínio pelo macabro e por certa dose de morbidez presente no leitor do gênero. Ironicamente, personagem do relato, não se dará conta de que ela própria se tornará vítima dessa narrativa e, mais, objetificada por seu algoz.

Por fim, é importante ressaltar que no relato de Pichón pululam outros relatos paralelos, relacionados com os crimes ou não. Da mesma maneira que Mme. Mouton tem acesso às narrativas dos crimes pelo rádio e pela televisão - como o leitor, Tomatis e Soldi o têm pela narrativa de Pichón -, em outras passagens a mídia aparece com inúmeros outros relatos da série de crimes:

Demás está decir que la prensa, la radio, la televisión e incluso el cine [...], para no hablar de la literatura, ensayística, pero también aunque parezca mentira de ficción, magnificaban el efecto ya de por sí espectacular de los acontecimientos (LP, p. 34)

Lo que sigue apareció en todos los diarios (LP, p. 175)

Su fotografía borrosa [la de Morvan] adornó, a varias columnas, la primera plana de los diarios. A un periodista se le ocurrió llamarlo "el monstruo de la Bastilla" [...] La prensa sensacionalista lo acusó de canibalismo y llegó a atribuirle, por medio de especulaciones tortuosas, varios crímenes que habían quedado sin resolver (LP, p. 179) 
Como estes relatos sobre os crimes se relacionam com a narrativa de Pichón e com a do romance em $\mathrm{si}^{12}$ será visto mais adiante, mas estes ainda não são os únicos relatos paralelos presentes aqui: há o vendedor de enciclopédias - um dos suspeitos iniciais, logo descartado - que vendia seu produto como magnífico, "según Le Monde" (LP, p. 38); há o discurso interno - na verdade um meta-discurso - de Lautret sobre o real e as representações ${ }^{13}$; há o discurso dos psiquiatras nos relatórios apresentados após a prisão de Morvan e citados no relato de Pichón com comentários sobre esse mesmo discurso ${ }^{14}$; há inclusive o discurso que não se manifesta, sufocado - "no hubo manifestaciones para lincharlo porque allá no se astilla” (LP, p. 179) -, ainda que a pulsão para gerá-lo exista “cada uno de los telespectadores y lectores de revistas [...] ya había puesto su cabeza en el cepo y había dejado caer mil veces la hoja de la guillotina” (LP, p. 179-80).

As próprias vítimas do assassino serial, segundo o narrador Pichón, produzem discursos que "revelan más los trasfondos del presente que los así llamados políticos, especialistas en ciencias humanas y periodistas" (LP, p.12). As velhinhas parisienses fazem “análises sociológicas" nos salões de chá, comentários mecânicos diante da televisão, conversam com seus canários - "único debate serio de los tiempos modernos" -, ostentam um “estilo oratorio, que a veces ni siquiera se expresa con palabras, sino más bien con silencios y ademanes significativos, con sacudimientos de cabeza para nada explícitos, y con miradas en las que se confunden ardor y desapego" (tudo isto em LP, p.12). Assim, a descrição da cidade

\footnotetext{
${ }^{12}$ Incluída aí a ironia com a metalinguagem, como a de afirmar que "parece mentira" que a literatura de ficção tome e aumente os efeitos de uma série de acontecimentos espetaculares como matéria prima em sua construção. Esta afirmação dentro de um texto de ficção é tão irônica como, ao mesmo tempo, leva a reflexão se a pensamos como parte de um texto ficcional de Saer.

13 "Lautret sabía por otra parte que la inmensa mayoría de los habitantes de ese continente, y también sin duda de los restantes, confunde el mundo con un archipiélago de representaciones electrónicas y verbales de modo que, pase lo que pase, si es que todavía pasa algo, en lo que antes se llamaba vida real, basta saber lo que se debe decir en el plano artificial de las representaciones para que todos queden más o menos satisfechos y con la sensación de haber participado en las deliberaciones que cambiarán el curso de los acontecimientos." (LP, p. 35)

${ }^{14}$ Não é sabido como Pichón supostamente tem acesso a esses relatórios, mas parece claro o domínio que tem sobre seus textos, não só no sentido do conhecimento que tem sobre eles, como na forma em que, ao mesmo tempo que discorre sobre eles, parece fazê-los se incorporar a seu próprio discurso. É fato, no entanto, que os textos dos relatórios definitivamente corroboram a narrativa de Pichón, servindo-lhe de álibi tanto quanto as notícias que supostamente saíram em todos os jornais de Paris. (LP, p. 186-7)
} 
feita pelo narrador se constitui em grande parte dos discursos produzidos pelas personagens que serão, ao fim, as vítimas na trama.

O relato de Pichón, então, se constitui de mil outros discursos que surgem dele e se entrelaçam. O personagem, assim, se utiliza de uma estratégia, acorde com o gênero, para contar sua história policial: não narra os crimes, e sim desenvolve uma narrativa sobre os crimes e sua elucidação - montada, por sua vez, a partir de outros discursos. Por outro lado, entretanto, esta mesma narrativa policial se mostrará como uma interpolação à outra que começa no segundo capítulo e da qual Pichón será personagem. A estratégia essencial do gênero policial, então, é extrapolada ao cenário de Santa Fe - onde outros personagens escutam o relato dos crimes e questionam a narrativa - e ao romance como um todo, que ganha uma nova camada de discursos entrelaçados.

\subsection{Um protonarrador saeriano}

Com uma fala de Carlos Tomatis se inicia o segundo capítulo do romance, interrompendo de forma brusca a narrativa desenvolvida até então - o relato dos crimes. Já de início se explicita esta narrativa como um relato de Pichón dirigido oralmente a amigos à mesa de um bar - "la historia que él, Pichón, viene refiriendo" (LP, p. 47) - e em relação ao qual Tomatis parece indiferente e desdenhoso, não somente por interromper o relato do amigo para comentar a temperatura da cerveja, como pelo caráter ambíguo do comentário: "Si está bien fría, tiene que doler acá cuando se toma" (LP, p. 47) - referente à cerveja ou à história?

O narrador neste ponto deixa de ser Pichón - convertido agora em personagem - e revela-se mais próximo do que chamaremos protonarrador saeriano, identificado, de maneira geral, no restante de sua narrativa com o que Julio Premat chama de cadência, "un ritmo, [...] una continuidad que se prolonga de título en título" (2009, p. 168). Como característico da 
narrativa deste protonarrador em La pesquisa ressaltam-se: a ação, mínima, passada na província de Santa Fe, na Argentina; os personagens - Pichón, Tomatis -, recorrentes em outras narrativas do autor; o tom da narrativa, as descrições, as divagações, digressões e recordações dos personagens que lembram o leitor familiarizado com Saer de outras narrativas do autor. Este narrador - e sua narrativa -, que dominará todo o segundo capítulo do romance, se alternará com o Pichón narrador do relato policial na metade final do romance - o último capítulo - sem propriamente se mesclar com ele, mas oferecendo ao leitor possibilidades de leitura que promoverão um entrecruzar de discursos, não só os do narradorPichón e do protonarrador saeriano, na composição do romance.

A trama contada nesta instância narrativa primária ${ }^{15}$ é, como já citado, mínima: em suma, três amigos - Pichón, Tomatis e Soldi - se encontram uma noite em um bar, onde jantam, bebem cerveja e conversam sobre diversos assuntos, mas especialmente sobre um manuscrito anônimo, o relato policial de Pichón e os temas, muitas vezes abstratos, especulativos e intelectuais, que deles se originam. Daí que o tempo lógico em que transcorre esta narrativa seja o espaço de algumas horas somente. Por outro lado, além dos relatos que são temas da conversação, recordações de um passeio feito por todos eles nesse mesmo dia e de momentos mais afastados no tempo e na memória, aspirações e sentimentos dos personagens, digressões diversas de personagens e narrador, tudo acaba por formar parte da instância narrativa primária. Passemos, então, ao que narra o protonarrador saeriano.

\footnotetext{
${ }^{15}$ Chamaremos aqui instância narrativa primária - assumida pelo protonarrador saeriano - esta que começa no segundo capítulo e que tem como personagem Pichón - instância narrativa secundária que dá conta do relato policial, ainda que este apareça antes. Cabe apontar, entretanto, que esta distinção rígida entre estas instâncias narrativas pode, e será, questionada em uma análise mais ampla da concepção do romance como um todo, que será levada a cabo mais adiante.
} 


\section{Personagens e ações}

Ainda que a narrativa que começa no segundo capítulo, como se disse, tenha lugar à mesa de um bar, à noite, durante poucas horas, boa parte deste capítulo tem como "ação" um passeio feito pelo rio Paraná e seus afluentes nesse mesmo dia até a casa do falecido Washington, antigo amigo e mentor de Pichón e Tomatis. Além deles, os acompanham no passeio o "Francesito", filho de Pichón, Alicia, filha de Tomatis - ambos de aproximadamente 15 anos - e Marcelo Soldi, o "Pinocho", amigo de Tomatis e conhecido de Julia, filha de Washington que cuida da casa e das coisas deixadas pelo pai. É Soldi também quem providencia a embarcação para o passeio, bem como seu condutor.

Antes que comece o passeio, contado pelo narrador e permeado por impressões e recordações dos que dele participaram, há uma espécie de situação dos personagens principais - Pichón, Tomatis e Soldi. Estes são, ao mesmo tempo, apresentados pelo narrador, muito em função da cena em que estão inseridos - a conversa no bar depois do passeio pelo rio -, e conformam, por pensamentos, ações e memórias, a si mesmos e aos outros. Assim, Pichón se pergunta se Tomatis não se deixou "contaminar por cierto etnocentrismo provinciano", ao mesmo tempo em que intimida a Soldi com sua "aura parisina", ao passo que este se sente também "encantado de participar en la cena" (LP, p. 48). Deste modo, o narrador aproxima o leitor dos personagens não diretamente por sua narrativa, mas, ainda que através dela, pelas impressões e imagens que fazem os personagens uns dos outros e de si mesmos - Pichón de Tomatis, Soldi de Pichón, Soldi de si mesmo.

A este esboço dos personagens seguem-se também as primeiras informações rudimentares sobre "En las tiendas griegas", texto datilografado anônimo encontrado entre as coisas de Washington depois de sua morte e que será objeto de interesse dos amigos. Apresentam-se também as perspectivas de Soldi - de que talvez Pichón possa ajudá-lo 
futuramente em uma estada em Paris - e de Pichón - a de que Soldi, "hijo de ricos" (LP, p. 48), possa ajudá-lo por sua vez na locomoção pelos lugares "ya casi legendarios, después de tantos años de ausencia, de su región natal” (LP, p. 49). Além disto, estabelece-se uma ruptura definitiva com o relato policial do primeiro capítulo pela contraposição do frio do inverno parisiense - que recém começava - e o calor do verão em Santa Fe - que está por terminar. Estas três páginas iniciais do segundo capítulo acabam representando, portanto, uma espécie de "sumário" da narrativa que se seguirá. A partir daí, aprofundam-se as descrições dos personagens, o relato do passeio, as discussões sobre "En las tiendas griegas", o relato policial de Pichón e outros temas que, de uma forma ou de outra, com eles vão acabar se relacionando.

Pichón, do qual já sabemos ser o narrador do relato policial, que vive em Paris e que está, depois de muitos anos, visitando sua terra natal ${ }^{16}$, tem sua descrição aprofundada pelo narrador a partir de seus sentimentos e sensações. Assim, seu sentimento de pertencimento à terra natal se contrapõe a uma sensação vaga e ao mesmo tempo intensa de estranhamento: o calor e a umidade lhe dão uma sensação ambígua "de que proviene de un lugar único cuyos rasgos definidos e inalterables coinciden al milímetro, a pesar y aun a través del tiempo y la distancia, con los mitos que, poco a poco y sin proponérselo, ha ido forjándose a partir de ellos". (LP, p. 50) A memória afetiva da terra natal forja então um discurso próprio, que dá conta do cenário "real" como lenda e como mito. O choque entre ambos - lugar real e lugar mítico - vai se revelando pouco a pouco para o leitor e para o próprio Pichón na narrativa. Já em seguida, sabe-se que este está hospedado na oficina do amigo Héctor - que por sua vez está na Europa - e que o motivo "oficial" da viagem - um tanto artificial, mesmo para o próprio Pichón - é a venda dos poucos e últimos bens da família depois da recente morte da mãe e do desaparecimento do irmão - ocorrido anos antes (LP, p. 51). Começa-se, então, a ter

\footnotetext{
${ }^{16}$ Descontando-se, claro, o que o leitor pode saber do personagem, recorrente nas narrativas de Saer, pela leitura, por exemplo, dos romances Nadie nada nunca (de 1980) e Glosa (de 1985).
} 
a consciência de que os laços reais do personagem com o lugar estão a ponto de se desintegrar por completo e que a dimensão mítica formada na consciência e na memória de Pichón o paralisa no presente. Seu filho, por outro lado, não tem memória do lugar e, por consequência, não é confrontado com o mito: na companhia de Alicia, filha de Tomatis, se envolve em inúmeras atividades todo o tempo. Para ele "las semanas son un flujo ardiente, inacabable y trabajoso" (LP, p. 52), enquanto para o pai o tempo adquire outra configuração:

En el remolino lento del día, no parece existir la dimensión del tiempo: el mundo es como una masa pegajosa en desenvolvimiento imperceptible, y el ser atrapado en la gelatina incolora no solamente no se debate, sino que parece aceptar, como sola opción posible, gradual, el hundimiento. (LP, p. 52)

Assim, o contraste entre a expectativa da viagem, por parte de Pichón, e a atonia sentida na chegada pode ser entendido como o choque entre dois lugares. O primeiro, elaborado pelo personagem mentalmente - pelas memórias, pelas lendas, pelo mito-, era único, inteiro e conformava uma representação absolutamente coerente. O segundo, que não pode ser completamente dissímil ao primeiro, já que lhe deu origem, não se amolda a ele como parece esperar o personagem: há algo de incômodo, de fora de tom, de decepcionante. É como se o ente sonhado se mostrasse ao fim, de alguma forma, disforme e monstruoso. Este embate entre dois discursos, um da expectativa e outro da realização, acaba extrapolando as reflexões de Pichón e convertendo-se em tema central do livro, como se verá também em outros pontos.

Já Tomatis é narrado a partir de sua relação com Pichón: há a expectativa da chegada do amigo, o reconhecimento de uma amizade antiga e da cumplicidade que os une, mas, por fim, também uma barreira, respeitada por ambos, que os mantém separados por silêncios e interditos. A partir desse ponto intransponível, só o que se pode conceber é uma imagem vaga que um faz do outro e que imagina que o outro faz dele. Tomatis, que obviamente não sente - 
ou não sente tanto, ao menos - o choque entre o "lugar mítico" e o "lugar real", já que vive aí, parece perceber o desconforto mais presente em relação ao tempo: o tempo da juventude em que convivia com os irmãos Garay e o atual em que um deles volta à região em outro contexto histórico, em outro tempo. Desta percepção, vem a aceitação do Pichón "real”, presente, que se apresenta à sua frente, evitando um choque com o Pichón "mítico", de um tempo já mítico, formado por sensações, mais que por recordações, de um passado distante e do tempo decorrido até então. Com menos desassossego que o velho amigo, Tomatis parece então aceitar melhor o descompasso entre o presente e "[1]a juventud [que] les parece haber quedado en una zona arcaica y fabulosa, [...] inaccesible a la experiencia pero también a la memoria" (LP, p. 54-5). Por este reconhecimento, por parte dos personagens, do irreconciliável entre um tempo mítico e um real - no qual só existe o presente - talvez declare o narrador que "[a] esta altura de sus vidas, y del modo más inesperado, el presente les da la impresión de ser el mejor de los mundos posibles" (LP, p. 54).

Soldi, por sua vez, vinte anos mais jovem, não compartilha o tempo mítico da juventude de Pichón e Tomatis, mas sim da narrativa mítica desse tempo, através dos relatos deste. Agora, inclusive, conhecendo pessoalmente a um dos gêmeos Garay, e ouvindo tudo o que conversam os amigos, às vezes "tiene que someterlo a una especie de traducción" (LP, p. 56, grifo meu). Com os personagens "em carne e osso" à sua frente, Soldi - que tem uma “extraña obsesión por las palabras" (LP, p. 57) - parece mais entretido e encantado em ler os personagens míticos e legendários que pairam por trás deles e de suas conversas. Ao presenciá-las, tem a impressão de "estar asistiendo a una comedia" na qual os personagens parecem "tan bien instalados en el presente, tan dueños de sus palabras y de sus actos, tan bien recortados como caracteres diferentes y complementarios" (LP, p. 135-6). Quando o narrador contesta esta interpretação de Soldi - "Es obvio que se equivoca" (LP, p. 136) -, o equívoco estará na simplificação da leitura, na pouca profundidade presumida dos 
personagens e das situações. Um discurso mítico, atemporal, está aí, enraizado em Pichón e Tomatis - antes, na zona santafesina das narrativas de Saer -, mas o jovem "filho de ricos" parece não conseguir alcança-lo de todo e traduzi-lo a contento. Só o que este vê é o presente, sem conseguir ir além, até por que Tomatis e Pichón não o deixam: "Lo que pasa es que, por una especie de complicidad estilística, [...] han aprendido a no mostrarlo demasiado" (LP, p. 138). Mais uma vez o choque entre perspectivas, expectativas de discursos, silêncios e malentendidos se instala como ponto central do romance.

O que segue de trama, aparte do já apontado, neste capítulo é mínimo: a viagem de ida e volta pelo rio até a casa de Washington, apesar do calor, transcorre tranquilamente e parece ser agradável para os que dela participam ${ }^{17}$. A visita à antiga casa do amigo e mentor falecido revela uma tensão entre Júlia - filha deste e atual dona da casa - e os convidados, dada a indisposição entre ela e os antigos companheiros do pai ${ }^{18}$, mas é proveitosa para Pichón, que pode finalmente examinar o misterioso manuscrito de "En las tiendas griegas".

Além disso, temos o narrador recontando a história do desaparecimento de Gato e Elisa, ao passar o barco pela casa de Rincón. À aparente indiferença de Pichón - ao contrário de seu filho que, por trás da "expresión impenetrable y serena", não conseguia disfarçar de todo "la emoción intensa que sentía" (LP, p. 81) -, soma-se, no relato do narrador, a descrição de medo, de mau pressentimento do amigo que encontrou a casa vazia e descobriu que o casal havia desaparecido, já que "eran tiempos de terror y de violencia" (LP, p. 82). A interpolação da narrativa de Gato e Elisa em La pesquisa não só fornece um elo a mais para a cadeia que entrelaça a obra de Saer, mas ressignifica também narrativas anteriores ${ }^{19}$ e volta ao centro do romance como o relato das narrativas que se cruzam. Os sentimentos de Pichón em relação ao desaparecimento do irmão, os motivos da emoção de seu filho, que neste momento não se

\footnotetext{
${ }^{17}$ Segundo o narrador, inclusive, para Pichón, o passeio "quedará sin duda como uno de los mejores momentos de su estadía" (LP, p. 85).

${ }^{18}$ Além de Tomatis, mencionam-se Rosemberg e Cuello - que se refere a Julia como "esa mujer" -, personagens também recorrentes na obra de Saer.

${ }^{19}$ Os já mencionados romances Nadie nada nunca e Glosa, por exemplo.
} 
revelam, irrompem no romance mais adiante - LP, p. 136-40. Do mesmo modo, Pichón também não revela aos outros o que reflete ao passar pelas ruínas do velho porto da cidade, já praticamente de volta à cidade, no fim do passeio e do capítulo. Mas a narrativa do que imagina Pichón se revela, sim, ao leitor: ao ver ao longe os restos arruinados de cimento e ferro, pensa na vida que ali existia, nas pessoas que ali viviam, em suas histórias e em todos os relatos, agora também feitos ruínas, de um tempo irremediavelmente perdido.

\section{A discussão no bar}

Terminado o passeio pelo rio e o segundo capítulo do romance, o terceiro se abre com Pichón retomando seu relato policial parisiense. Nesta metade final do livro, as duas instâncias narrativas principais - a de Pichón, secundária, e a do protonarrador saeriano, primária - vão se intercalar tendo como base o tempo presente, por assim dizer, da instância primária, ou seja, o encontro dos três amigos em um bar. Além do relato policial, será tema importante das conversas entre eles o manuscrito encontrado na casa se Washington, que havia motivado a excursão naquele mesmo dia, e os reflexos que esta deixará em seus participantes.

O texto encontrado por Soldi entre as coisas de Washington depois de sua morte e que será para ele, e depois para todos, "no el manuscrito, sino el dactilograma" (LP, p. 61), revelará motivos para ser designado assim. Ainda que escrito à máquina e não a mão - o que parece, a princípio, querer justificar o rechaço pelo termo "manuscrito" - o texto desperta uma primeira curiosidade ao ser denominado sempre como "dactilograma", como se isso fosse uma maneira de dizer "texto datilografado", ou "texto mecanografiado", em espanhol. Na verdade, o termo significa, segundo o dicionário da Real Academia Española, a impressão 
digital em uma superfície ${ }^{20}$ e cria-se uma ambiguidade de significados: não parece fazer muito sentido chamar o documento encontrado de "impressão digital", mas ao se pensar que "dactilograma", pode remeter a "dactilógrafo" e a "dactilografiar", é lícito imaginar que Soldi tenha usado o termo para o documento como forma de diferenciá-lo de um manuscrito literalmente, escrito a mão. Esta possível criação de um novo significado para "dactilograma" imaginado por Soldi, conscientemente ou não, acaba ressaltando para o leitor do romance a característica essencial de "En las tiendas griegas": a de que a este texto só temos acesso indiretamente, através de relatos de outros. O texto que se emparelha com o relato policial, portanto, é mera "pista", mera "impressão", o que não impede que os personagens e o leitor de La pesquisa possam conjecturar sobre ele.

É da trama desses relatos, de seus entrecruzamentos, dos novos discursos que brotam a partir de tudo isso, que se alimenta a conversa de bar entre Pichón, Soldi e Tomatis, da qual dá conta a narrativa do terceiro e derradeiro capítulo de La pesquisa.

As referências a "En las tiendas griegas" começam a aparecer já no início do segundo capítulo (LP, p. 49) e voltam de tanto em tanto na narrativa até o final do romance, cada vez agregando-se alguma informação a mais sobre o texto. Dele sabemos, especialmente, o que o narrador nos faz chegar através das descrições de Soldi, já que Tomatis faz apenas alguns comentários sobre o texto e Pichón, ainda que examine o datilograma na casa de Júlia, não terá sequer a oportunidade de lê-lo na íntegra. Sabemos, então, por Soldi, ainda antes do passeio do rio, que: o texto havia sido encontrado entre as coisas de Washington, depois de sua morte, em um baú etiquetado como "INÉDITOS AJENOS"; trata-se de uma cópia - o que se deduz de elementos tipográficos do datilograma -; deve ter sido escrito depois de 1918 - já

\footnotetext{
${ }^{20}$ Segundo o dicionário on-line da RAE: “dactilograma: huella digital impresa en una superficie con fines legales de identificación". Também em português, segundo o Dicionário Houaiss (on-line): "datilograma: impressão digital ('marca', 'reprodução')".
} 
que é neste ano que aparece o poema homônimo de César Vallejo ${ }^{21}$-; suas 815 páginas começam e terminam com reticências; o relato tem como tema a guerra de Tróia e se passa no cerco à cidade, no Escamandro (todos estes dados referidos em LP, p. 66). Posteriormente, na volta do passeio, Soldi, em um resumo oral da trama feito a Pichón, agrega que os personagens principais de "En las tiendas griegas" não são na verdade as figuras mais lendárias e conhecidas da famosa guerra - Helena, Paris, Menelau, Agamenon, Ulisses -, mas dois soldados anônimos, o velho e o jovem, "la doble voz cantante del relato" (LP, p. 86), segundo Soldi. Por fim, se agregará que a maior parte do romance relata a conversa entre os dois soldados e que a trama se passa em uma só noite - a anterior à introdução do Cavalo na cidade de Tróia e à destruição desta. Com o pouco que se sabe da trama de "En las tiendas griegas", os personagens de La pesquisa - cuja instancia narrativa primária tampouco desenvolve uma trama pródiga em peripécias e que também concentra sua ação principal em uma noite - fazem das leituras, das suposições e dos questionamentos intermináveis do discurso do outro - seja este "outro" quem for - e de si mesmos o motor de sua conversação e, por extensão, do romance de Saer.

No capítulo final, por exemplo, a discussão sobre "En las tiendas griegas" chega trazida e se mistura à que já se desenvolvia sobre o relato policial de Pichón. Este é contestado por Tomatis, a princípio com desprezo, quando a trama parece apontar para a culpa de Lautret no caso dos assassinatos de velhinhas: "la solución me parecía evidente desde el principio" (LP, p. 133). Pichón, por sua vez, não tendo terminado sua narrativa, protesta - "es que a esta altura del relato no hemos llegado a la solución, sino al comienzo del problema” (LP, p. 133) -, não conseguindo, contudo convencer o amigo:

\footnotetext{
${ }^{21}$ Não seria possível, entretanto, que Vallejo tivesse tomado por título de seu poema o título de um romance histórico ainda mais antigo e não publicado, exatamente este que discutem agora os amigos santafesinos?
} 
- Suspenso barato - dice Tomatis, dirigiéndose no a Pichón, sino a Soldi, pero señalando a Pichón con un movimiento de cabeza significativo que, traducido a palabras podría decir: Te hago notar los métodos poco recomendables que emplea este individuo para embaucarnos con su historia. (LP, p. 133, grifo do autor)

A partir daí, se estabelecerá, então, uma discussão sobre o valor do relato de Pichón e, mais importante, do status de verdade de sua narrativa. Ao fim, Tomatis aceita sem muita convicção a história do amigo - "Es posible" (LP, p. 191-2), repete várias vezes -, mas elabora sua própria versão do relato, "la solución más simple” (LP, p. 192), segundo a qual seria, de fato, Lautret o criminoso. Utilizando a própria narrativa de Pichón, e aproveitando-se da ambiguidade de alguns elementos do caso $^{22}$ - tratados como "provas frágeis" contra Morvan, ou mesmo ambivalentes -, Tomatis chega a assumir a narrativa por algumas páginas ao final de La pesquisa para apresentar sua versão ${ }^{23}$.

Para o leitor de La pesquisa, que lê o relato de Pichón, as ambiguidades se desdobram ainda mais. Ao refletir em seu escritório sobre o assassino, pensa o comissário chefe (LP, p. 44, grifo meu):

Como ya lo ha hecho tantas veces, se decía Morvan, cuando llegue la noche saldrá tal vez sin apurarse de su penumbra informe y densa, merodeando por las calles casi desiertas, en las inmediaciones de la plaza, buscará con expresión indolente y ordinaria su nueva presa, abordándole de un modo tan natural y familiar que, en estos tiempos de amenaza, la anciana verá en él, no una amenaza, sino una protección inesperada viril y cálida [...]

De quem fala o trecho acima? De Morvan ou do assassino, nesse momento ainda desconhecido? O mesmo acontecerá no momento em que o comissário crê ter identificado em seu colega Lautret o criminoso (LP, p. 126-33). Todo o raciocínio que desenvolve para o

\footnotetext{
${ }^{22}$ A carta do Ministério, as garrafas de champanhe, as luvas de látex, o caso de Lautret com Carolina, ex-mulher de Morvan, o caráter solitário e atlético deste, etc

${ }^{23}$ A discussão entre Tomatis e Pichón sobre o desfecho do relato criminal e a possibilidade de culpa de Morvan continuará no conto "Recepción en Baker Street" (2006b, p. 83-105), publicado em Lugar (de 2000) e que é um prolongamento da narrativa de La pesquisa em que Tomatis tece sua própria história policial tendo como protagonista Sherlock Holmes.
} 
reconhecimento e identificação do maníaco se ajustará perfeitamente a sua própria pessoa e sua própria personalidade - sem deixar de encaixar-se também na de Lautret. Quando quer explicar a loucura do assassino, conjectura que "[v]ivía tan intoxicado por el veneno que circulaba por su ser, con su sangre tal vez [...]" (LP, p. 130). O transtorno que faz Morvan imaginar o amigo acometido de uma transformação, como um Dr. Jekill, será uma das bases do discurso que, posteriormente, o condenará. Para os psiquiatras e seus relatórios, a loucura de Morvan se explicaria - ou teria, ao menos, origem - no abandono e rechaço da mãe: sua ruína viria, portanto, desde o ventre materno e corria em seu sangue. O relato de Pichón, se dá brechas para a versão alternativa da história de Tomatis, também - especialmente quando relido - se desdobra em novos significados com a revelação da culpa de Morvan procedimento que, na verdade, é praxe na narrativa policial tradicional. Mas o que garante o relato de Pichón?

Quando se relaciona o "veneno que corre nas veias do assassino" com a explicação psiquiátrica para a culpabilidade de Morvan, não se pode descartar simplesmente a associação desse mesmo veneno com a armadilha da qual o comissário poderia ter sido vítima. Outros elementos, entretanto, parecem menos passíveis de discussão, segundo o relato de Pichón. Mesmo que ainda sob o efeito de drogas, parece não haver dúvidas da dissociação que sente Morvan entre quem é e a imagem que vê no espelho ao acordar nu no banheiro do apartamento de Mme. Mouton. Também é em um momento claramente de vigília supostamente lúcida - que Morvan tem uma alucinação erótica em um restaurante chinês quando vê que "en el fondo de la tacita de porcelana una muchacha oriental, desnuda, le sonreía en una pose provocativa" (LP, p. 162). Em seguida, a diminuta imagem desaparece. Por fim, como "prova cabal” de seu delírio, há o episódio em que o comissário sai para um passeio à noite e, exausto e sem se dar conta, volta ao escritório onde dorme ainda vestido, sendo acordado por um colega na manhã seguinte (LP, p. 104-10). As lembranças da noite 
anterior desapareceram, mas Morvan sabe ter tido seu sonho recorrente com a cidade fantasmagórica e as notas de dinheiro com efígies de monstros mitológicos. O sonho não era uma novidade e não apresentava nenhuma diferença significativa das suas versões anteriores. Entretanto, algo é sutilmente mencionado pelo narrador quando naquela manhã, depois de ser despertado pelo colega, o comissário sai em uma diligência - na qual encontrará uma das vítimas do maníaco homicida - mal tendo tempo de se recompor do sono agitado que tivera: "Su único desayuno fue el vaso de agua en el que disolvió la aspirina efervescente" (LP, p. 111, grifo meu). Esta aspirina, guardada no bolso do sobretudo, havia sido compradas, porém, em uma farmácia na noite anterior, onde Morvan recebeu como troco as notas onde se viam as figuras de Cila, Caríbdis, Górgona e Quimera. Dada a impossibilidade de se consumir na vigília um produto adquirido em um sonho, fica patente que os sonhos do detetive haviam evoluído para uma alucinação da qual ele padecia estando desperto.

Ainda assim, tudo isso é, não se deve nunca esquecer, o relato de Pichón e não deve ser tomado como verdade dos fatos porque ele o diz - lembremo-nos de que sua narrativa se trata de uma instância secundária interpolada na instância narrativa primária do romance, podendo, assim, ser questionada pelos outros personagens desta. Tomatis e Soldi, de fato, questionam o relato do amigo, e mesmo a principal justificativa de Pichón para o valor de sua narrativa - "Salió en todos los diarios" (LP, p. 140-1) - não convence a ninguém. Na verdade, a defesa da autoridade dos jornais como base da narrativa - a princípio, um tanto ingênua será problematizada pelo próprio Pichón, que desde o início de seu relato - e do romance - se mostra mais ou menos explicitamente um narrador mais astuto e envolvente do que ingênuo. Quando este narrador abre sua história com as referências ao rapto de Europa por Zeus e depois tomamos conhecimento do livro de mitologia da infância de Morvan e de toda a simbologia mitológica que reveste sua loucura, uma dúvida se instala: é Pichón que se apropria do imaginário de seu personagem em sua narrativa? Ou, ao contrário, é Pichón, o 
narrador culto, quem lhe atribui ao personagem uma simbologia que a Morvan, na verdade, não lhe pertence? O próprio narrador Pichón, já no início de seu relato, explicita a questão (LP, p. 22):

Ustedes se deben estar preguntando qué posición ocupo yo en este relato, que parezco saber de los hechos más de lo que muestran a primera vista y hablo de ellos y los transmito con la movilidad y la ubicuidad de quien posee una consciencia múltiple y omnipresente, pero quiero hacerles notar que lo que estamos percibiendo en este momento es tan fragmentario como lo que yo sé de lo que estoy refiriendo [...].

Neste ponto, o narrador admite o caráter artificial e fragmentário de seu discurso e assume a narrativa como uma ilusão de coerência e unidade. O uso de estatísticas algumas páginas antes, como a defesa da autoridade dos jornais mais adiante - "Salió en todos los diarios" (LP, p. 140-1) -, é admitido pelo próprio narrador como um ato de prudência, e mesmo de cortesia, "con el fin de probarles la veracidad de mi relato". Mas um ato supérfluo, segundo este próprio narrador (LP, p. 23):

ya que por el solo hecho de existir todo relato es verídico, y si se quiere extraer de él algún sentido, basta tener en cuenta que, para obtener la forma que le es propia, a veces le hace falta operar, gracias a sus propiedades elásticas, cierta compresión, algunos desplazamientos, y no pocos retoques en la iconografía.

Assim, quando Pichón é confrontado pelos amigos, se defende com a autoridade dos jornais e é ironizado por isso - “¿Esa sería la prueba de su veracidad?” (LP, p. 140) -, afirma, decidido: "No me refiero a la veracidad de la historia, sino a la mía" (LP, p. 141). O que Pichón defende, então, é a verdade de sua ficção, não que esta corresponda com os fatos empíricos, reais - os assassinatos de velhinhas em Paris - que a inspiraram. Esta discussão da verdade da ficção versus a verdade da experiência é o que propicia que, no meio da conversa, 
Soldi possa voltar com a narrativa do datilograma anônimo: "Desgraciadamente, el autor de En las tiendas griegas ya se ha abocado a ese problema" (LP, p. 161, grifo do autor).

Diante da expressão de surpresa de Pichón - que não conhecia o texto na íntegra -, Soldi lhe explica que os dois soldados, o velho e o jovem, são os personagens principais da história que se encontram em um acampamento nas imediações de Tróia na noite anterior à tomada da cidade. O Soldado Jovem vem da Grécia com a mente povoada por todas as narrativas que circulavam entre os gregos sobre a Guerra de Tróia, conhece todos os grandes heróis, os personagens e as batalhas mais célebres, tem, enfim, uma extensa narrativa sobre todos os acontecimentos. Já o Soldado Velho, membro da guarda particular de Menelau, há muitos anos no centro dos acontecimentos, não sabe de nada disso, não é capaz de reconhecer os grandes personagens da guerra, nunca participou diretamente de uma batalha - as quais só vê muito ao longe - e reconhece um troiano somente como uma das figurinhas minúsculas que às vezes vê passar sobre a fortaleza da cidade sitiada. Diante do espanto do Soldado Jovem em relação à ignorância de seu colega, o Soldado Velho decide que, se algum dia regressasse a Esparta e tivesse um tempo de ócio, "lo dedicaría a informarse de todos esos acontecimientos tan conocidos en el mundo y que el Soldado Joven acababa de referirse" (LP, p. 146).

O resumo de Soldi dessa passagem importante de "En las tiendas griegas" gera o diálogo entre ele e Pichón - ao qual Tomatis acompanha satisfeito - sobre os estatutos dos discursos do real e da ficção (LP, p. 146):

- El Soldado Viejo posee la verdad de la experiencia y el Soldado Joven la verdad de la ficción. Nunca son idénticas pero, aunque sean de orden diferente, a veces pueden no ser contradictorias - dice Pichón.

- Cierto - dice Soldi -. Pero la primera pretende ser más verdad que la segunda. [...]

- No lo niego - dice -. Pero a la segunda, ¿por qué le gusta tanto venderse en las casas públicas? 
Esses dois discursos que se contrapõem - o da experiência do Soldado Velho e o da ficção do Soldado Jovem - são só alguns dos que se entrecruzam na composição de $L a$ pesquisa: alguns já foram vistos, outros ainda se verão mais adiante. Mais do que o entrecruzamento das narrativas, o que se percebe é como elas se questionam, procuram se justificar, se rechaçam, se desmentem. Dentro da própria narrativa do Soldado Jovem referida, por sua vez, por Soldi - está a história de que Helena, na verdade, teria sido escondida no Egito e estaria esperando até aquele momento por seu marido. Páris teria raptado e levado para Tróia, então, um "simulacro de Helena" feito a partir de "formulações mágicas". O que lhe contesta o Soldado Velho ao ouvir a narrativa do Soldado Jovem “(según Soldi memorablemente, y en la novela en mejores palabras que las que él estaba transmitiéndoles de forma sucinta)" (LP, p. 145) - é que, se isso fosse verdade, a guerra, então, seria um simulacro. Assim, dentro da narrativa mítica, ficcional, da Guerra de Tróia ou seja, do simulacro - há uma história que converte a própria guerra "real”, inspiradora do mito e da ficção, em simulacro, inspirada por uma ficção - a falsa Helena -, conjurada por um mago.

Resta, a partir de então, buscar entender se há um discurso anterior que abarque este procedimento de entrecruzamento de discursos. Ou, dito de outro modo, se é possível identificar o protonarrador saeriano como conformador de uma narrativa coesa e coerente por trás do romance e dando conta dos entrelaçamentos de relatos em prol de um discurso maior, dentro da cadência narrativa do autor, de que fala Premat.

\subsection{A narrativa de La pesquisa}

O narrador do relato policial, Pichón, usa, quando lhe parece que vai lançar mão de uma palavra ou expressão gasta, ou um clichê, a expressão "como se dice". Por exemplo, 
quando diz que "la atmósfera anunciaba, como se dice, nieve" ou "conocía como se dice como la palma de la mano" (LP, p. 13 e 25-6). A expressão, com o mesmo sentido de denunciar um artifício gasto da narração, se repete no relato de Pichón por doze vezes (LP, p. $13,25,31,33,40,43,101,163,166,175)$, denunciando, a princípio, uma característica de estilo distintiva dentro do discurso do personagem. Entretanto, a mesma expressão aparece também na instância narrativa primária - no protonarrador saeriano - outras cinco vezes (p. $55,78,137,193)$ pondo em cheque a constatação anterior - a de que a expressão seria um traço de estilo de Pichón e seu relato. Sugere-se, então, que a suposta "narrativa de Pichón" não é mais que, ela própria, um simulacro, um recurso do narrador primário do romance para introduzir em sua narrativa um relato paralelo mais, a história policial contada por Pichón assim como o faz com a versão da mesma história contada por Tomatis ou os resumos orais de "En las tiendas griegas" feitos por Soldi.

Extrapolando o texto de La pesquisa, pode-se perceber que o uso da irônica expressão autodenunciante do artifício da narração está presente em muitos textos de $\mathrm{Saer}^{24}$. Além disso, o "como se dice" saeriano aparece nesses contos e romances tanto no discurso de um narrador mais neutro, em terceira pessoa, como no discurso de narradores em primeira pessoa. Ou seja, mais do que um recurso de um narrador em um texto, trata-se de um recurso que um virtual protonarrador saeriano atribui ao discurso de narradores diversos em textos diversos e que constitui uma das características que constitui o tom, a cadência, o ritmo que conforma a práxis narrativa de Saer.

Voltando a La pesquisa, não é difícil notar que, além de aspectos discursivos e linguísticos que entrelaçam os relatos no romance - como o visto acima -, também várias

\footnotetext{
${ }^{24}$ Em contos, como o mencionado "Recepción en Baker Street", ou nos romances: em Glosa, duas vezes na página 193 (SAER, 2006c); em El entenado, na página 10 (SAER, 2008b); em Las nubes, nas páginas 36 e 38 (SAER, 1997b); em Lo imborrable, mais de 30 vezes (!) ao longo do romance. (SAER, 1993).
} 
outras pistas podem levar o leitor a se enredar nos relatos, nas referências - intra ou extratextuais - como se verá a seguir ${ }^{25}$.

\section{Os discursos que se entrelaçam}

Dos discursos entrelaçados em La pesquisa, destacam-se, como já foi visto, a instância narrativa primária (o protonarrador saeriano) e a instância narrativa secundária (a narrativa de Pichón do relato policial) - ainda que, esta, como também já analisado, como simulacro criado pela primeira. De qualquer forma, são os dois relatos que se recortam de forma mais clara, cada um dominando um dos primeiros capítulos, constituindo-se o terceiro de uma alternância entre os dois.

Apesar da narrativa de Pichón ser um simulacro, é quando ela se introduz que se tem um narrador em terceira pessoa - neutro, distante - falando de imediato, ainda que, com exceção do início do romance, modulado por expressões que evidenciam o personagem se dirigindo a seus amigos - "Morvan estaba, como les decía [...]" (LP, p. 93, grifo meu) - ou a presença do protonarrador saeriano "narrando Pichón" - "y continúa:”; "dice de pronto Pichón”; “dice por fin” (LP, p. 100; 151; 156).

Já quando se introduz a instância narrativa primária - que se poderia supor mais neutra e distante dos personagens - geralmente é Tomatis que, interrompendo o relato de Pichón, toma a palavra e introduz com uma fala de personagem a narrativa. Isto chega a incomodar Soldi $^{26}$ e faz com em uma das ocasiões sua fala seja interrompida por Pichón: “!Shhtt! [...] Ya te tocará el turno. Pero por ahora silencio: aquí el que cuenta soy yo" (LP, p. 154). Depois,

\footnotetext{
${ }^{25}$ Como já notou María Teresa Gramuglio, a narrativa de Saer "conduce a la problematización del relato y a la reflexión sobre las condiciones de posibilidad de escritura, apelando ostensivamente a la intertextualidad, bajo la forma de relaciones con textos ajenos y propios que son retomados, aludidos, citados, parodiados" (REALES, L.; PREMAT, J.; MONDRAGÓN, J.C., 2010, p. 50)

26 "las interrupciones de Tomatis, obstinado a dar a conocer su opinión a cada rato, lo irritan ligeramente" (LP, p. $155)$.
} 
na última alternância de discursos, é o protonarrador quem narra, falando de Tomatis: “A pesar de que lo ha estado escuchándolo con atención profunda [...]” (LP, p.190). Assim, o jogo que entrelaça as narrativas no romance começa já na forma em que estas surgem e ocupam seus espaços - depois de advertido por Pichón, Tomatis passa a escutá-lo atentamente, por exemplo. No entanto, estes não são, como já se mencionou, os únicos discursos que permeiam o romance.

Dentro de La pesquisa, além das narrativas de Pichón e do protonarrador saeriano, estão, por exemplo, a de Soldi - indiretamente, narrando "En las tiendas griegas" em seus resumos orais feitos aos amigos e que vão permeando o romance - e a de Tomatis - que, de fato, assume o papel de narrador ao propor sua versão alternativa para o relato policial. Outras menores abundam na trama, como as criadas pela imaginação de Morvan ao pensar na senhora que havia ligado para a Brigada Criminal ou a que ele percebe ao ser recebido pela Mme. Mouton - a maneira como ela "atuava" e a "atmosfera de simulação" e sedução criada no apartamento (LP, p. 165).

Alguns discursos, no entanto, parecem ter papel mais fundamental na constituição do romance. $\mathrm{O}$ veiculado pelos jornais, revistas, televisão, rádio, a imprensa em geral, enfim, ainda que não exposto explicitamente, é crucial. Em primeiro lugar, pelo uso que fará deles ou dos jornais, ao menos - Pichón para justificar a "verdade" de seu relato aos amigos. Em segundo lugar, porque eles servem como uma das justificativas para que as velhinhas, na trama, deixem que seu assassino entre em seu apartamento sem medo algum - seja ele Morvan ou Lautret, como na versão de Tomatis, já que os dois eram conhecidos e tinham suas imagens veiculadas pela mídia. Se os relatos da imprensa são tomados por Pichón como garantia de "verdade", não dos fatos, mas de seu relato, o que se mostrará, na verdade, tremendamente irônico, é também com ironia que ele descreve a passagem da história dos relatos da imprensa para a representação estética do cinema e da literatura, não só ensaística, 
"pero también aunque parezca mentira de ficción” (LP, p. 34). A consciência do narrador aqui, Pichón narrando a história policial, mas transparecendo o protonarrador saeriano do qual, como se viu, é um simulacro - do artifício que é a narração é, ao mesmo tempo, sutil e reiterada, deixando a reflexão possível de que toda literatura de ficção parece mentira, especialmente quanto mais tenta simular a verdade.

Outro exemplo de discurso inviável para a coerência da trama e, ao mesmo tempo, fundamental para ela é o dos discursos psiquiátricos. Estes servem à narrativa policial como explicação para a loucura assassina de Morvan, o que, de resto, se poderia induzir por vários outros elementos do relato: a ausência da mãe, a descoberta do abandono, o suicídio do pai, a separação da mulher, etc. Entretanto, como Pichón tem acesso tão detalhado a estes relatórios - a ponto de comentar o vocabulário utilizado e o tom não científico de algumas passagens, como a que cita Oscar Wilde ${ }^{27}$ - não se sabe. Que tantas informações tenham saído na imprensa parece pouco provável e que, de algum modo, o narrador tenha tido acesso direto aos documentos não é mencionado.

Se os aspectos práticos, por assim dizer, na construção da coerência do relato de Pichón - como os jornais como base factual para a narrativa e os relatórios psiquiátricos como explicação para a loucura do personagem - revelam, paradoxalmente, incoerências, fissuras também são encontradas em aspectos estilísticos da narrativa, como a utilização por Pichón das imagens mitológicas na abertura do romance, sendo que estas formariam parte, na verdade, do imaginário de Morvan. A não ser que as referências sejam primeiramente de Pichón, que as aplica a seu personagem. Neste caso, a justificativa de que a história é verdadeira porque "saiu em todos os jornais" é, ao menos em parte, falsa: os delírios com

\footnotetext{
${ }^{27}$ Segundo os relatórios, havia em Morvan "un intento de desentrañar - ignoro si la palabra fue elegida a propósito por los redactores del informe - el supuesto misterio del cuerpo materno" e "[1]as violaciones pre y post mortem eran también, según los psiquiatras, un síntoma de ambivalencia, que demostraba el deseo sexual hacia su madre, y en una nota al pie de página, en una tono extracientífico, de tipo aforístico-filosófico más bien, el informe hacía notar que ese amor instintivo y demencial por la madre que lo había abandonado, de igual modo que la confianza y la atracción erótica de las viejecitas por su verdugo demostrarían que, más allá de lo que decía Oscar Wilde, que el informe cita con nombre y apellido, los seres humanos no sólo destruyen lo que aman, sino que sobre todo, aman lo que los destruye" (LP, p. 186-7).
} 
Cila, Caríbdis, Górgona e Quimera, substância da loucura do detetive não passariam de "invenções" do narrador. Por outro lado, a coincidência das figuras do livro sobre a queda de Tróia e personagens como Ulisses e a narrativa de "En las tiendas griegas" seria inverossímil, deixando entrever novamente o protonarrador saeriano que conduz, de fato, todas as narrativas, criando-as como simulacros de discursos autônomos.

O que revelam, ao fim, estes jogos de discursos do romance é a ambiguidade de toda narrativa possível, entre a autonomia de sua verdade intrínseca - "ya que por el solo hecho de existir todo relato es verídico" (LP, p. 23) - e, ao mesmo tempo, a dependência de outros discursos para que possa existir. Assim, o narrador primário, em determinado momento, passa três páginas descrevendo o bar onde se encontravam os amigos a partir do ponto de vista ${ }^{28}$ de cada um deles, para, por fim, concluir (LP, p. 99-100):

\begin{abstract}
A pesar de que están los tres juntos, sentados a la misma mesa, a causa de la posición diferente que ocupan en ella, cuando la noche que comparten les vuelva a la memoria, no tendrán los mismos recuerdos. Es obvio que también del relato de Pichón cada uno tendrá una visión diferente, no únicamente Soldi y Tomatis, sino sobre todo Pichón, que nunca podrá verificar el tenor exacto de sus palabras en la imaginación de los otros.
\end{abstract}

Em outros casos, os discursos, calados e sem interlocução, se convertem em fantasmas de uma realidade inverificável, como são as nuances do relacionamento entre Pichón e Tomatis. Depois do desaparecimento do Gato Garay e de Elisa - durante os anos da ditadura militar argentina no fim dos anos setenta -, Pichón, que já vivia na França havia mais de dez anos, se recusa a voltar à Argentina para procurar o irmão. Por isso, Tomatis que era seu amigo praticamente desde a infância, rompe o contato, realizado principalmente por cartas, com Pichón por cerca de dois anos, até que volta a escrever-lhe dizendo compreender seus

\footnotetext{
28 "Ponto de vista", aqui, deve ser encarado literalmente, já que o narrador descreve, a partir da posição em que estão sentados Pichón, Tomatis e Soldi, o que cada um vê do bar e das ruas em volta (LP, p. 97-9).
} 
$\operatorname{motivos}^{29}$. Estes fatos voltam na instância narrativa primária, que revela que ambos guardam culpas dessa época e, ainda que mantendo uma relação harmoniosa, tranquila e cúmplice, sobram palavras e sensações não ditas entre eles. Se Pichón sente um remordimento profundo por não ter buscado o irmão, agravado agora por sua aparente apatia e desinteresse sequer pela casa de Rincón, Tomatis sente uma ponta de humilhação ao imaginar um interesse fingido de Pichón pelo manuscrito de Washington ou pelas coisas da terra natal. Estas são verdades que não aparecem em nenhum discurso entre eles. O remorso e a demonstração ainda que, em parte, falsa - de apatia de Pichón; os sentimentos de rejeição que sente Tomatis; são culpas que cada um atribui a si mesmo, aceitando o outro como é. Mas se muitos silêncios refletem o acordo tácito de aceitação e respeito mútuo, também disfarçam e embaralham as ideias e o entendimento que um faz do outro.

Como muitos discursos surgem e perpassam pelo texto de La pesquisa, outros tantos, também entrelaçados a esses, extrapolam o romance em confluências de referências às vezes mais, às vezes menos, explícitas. Serão assim tanto os casos em que a obra de Saer - com suas obsessões, seu tom, seus personagens recorrentes, seus cenários míticos - cobra presença em La pesquisa, como as situações em que textos de outros autores dialogam com diversas situações e discussões do romance.

O uso de uma expressão em um contexto bastante específico - "como se dice" -, tanto na instância narrativa primária como na narrativa policial de Pichón, já evidenciou uma superestrutura discursiva presente em La pesquisa, à qual se chamou protonarrador saeriano, reforçada por sua presença em outros textos da obra do autor argentino. Este denunciante linguístico, entretanto não é o único ponto do romance que revela um diálogo com a obra de Saer.

\footnotetext{
29 “[H]abía terminado por comprender que esa prudencia excesiva del amigo era en realidad miedo, pero no miedo de correr, como se dice, la misma suerte que su hermano, sino, por el contrario, miedo de afrontar la comprobación directa de que el inconcebible ente repetido [...] se hubiese evaporado sin dejar rastro en el aire de este mundo, o peor todavía, que en su lugar le presentaran un montoncito anónimos de huesos sacados de una tierra ignorada. (LP, p. 137-8)
} 
Apesar do subjetivismo perigoso latente na tentativa de definição de um "estilo de autor" que ligaria o discurso de La pesquisa com os de outros textos de Saer, é inegável a presença de algumas obsessões narrativas do autor ${ }^{30}$, ou, usando a terminologia de Julio Premat (2009), de seu tom, sua cadência. O ponto de onde se irradia toda a narração, por exemplo, não deixa de ser a Zona, o pedaço mítico da província de Santa Fe que se constrói em toda a obra de Saer, porque, voltando a Premat, "ser escritor es, en Saer, ser un escritor con un territorio, un escritor que se construye un lugar" (2009: p. 167), e - a respeito da coletânea de contos Lugar - "al haber ya construido un espacio literario fuerte y reconocible, el mundo entero entra en él” (p. 190). Por isso Pichón descreve as velhinhas parisienses "en las márgenes del tiempo, igual que esos remansos en los ríos en los que el agua parece detenida y lisa, debido a una fuerza invisible que frena la corriente horizontal, pero tira inexorablemente hacia el fondo" (LP, p. 11). Ainda que um personagem de Santa Fe familiarizado com o rio, portanto -, o Pichón narrador é, antes, um simulacro de narrador autônomo criado pelo protonarrador saeriano e a imagem que faz do rio é extremamente semelhante à que surge em Nadie nada nunca, por exemplo. Por outro lado, na instância narrativa primária de La pesquisa, quando no passeio o barco passa pelo Arroyo Ubajay, Pichón pensa que, mesmo sendo este tão largo como o Sena na altura da Pont dês Arts, "por acá todo el mundo lo llama arroyo (LP, p. 82). A Paris - ou qualquer outro lugar - na narrativa de Saer cabe em Santa Fe, esta zona que o autor construiu como seu espaço literário. Um reflexo desta ideia do território de um escritor dentro da narrativa aparece no relato de "En las tiendas griegas" - referido indiretamente por Soldi. Ao descrever que o Soldado Jovem conhecia todos os relatos heroicos referentes à Guerra de Tróia, agrega que "no únicamente él, sino toda Grecia, lo que equivalía decir el universo entero" (LP, p. 143). Claro

\footnotetext{
${ }^{30}$ Sobre as obsessões do assassino em La pesquisa - em especial a delimitação estrita do espaço em que se cometiam os crimes, o narrador Pichón comenta que "en esta restricción había sin duda un elemento significativo, del que era difícil decidir si se trataba de un azar persistente o de un desafío, una especie de regla que el asesino se imponía, un capricho transformado en obligación igual a los que se someten la locura o el arte" (p. 15). Seria esta arte submetida a uma obsessão e a desafios a que almeja Saer como escritor?
} 
está que a afirmação leva embutida a ideia da Grécia como centro do universo na época partida da concepção de Soldi ou de uma espécie de autoconsciência do soldado -, mas, por outro lado, também a de que o universo a partir do qual um grego pensa o mundo é, obviamente, a Grécia.

Com tudo isso, com a marca da zona saeriana onipresente em La pesquisa, é um personagem do romance que explicita o sentimento de que ser adulto é perceber que a terra natal não é onde se nasce, e sim o mundo onde nos tornamos o que somos. O lugar de Saer é, então, sua própria existência humana, sua realidade no mundo ${ }^{31}$ :

En un fulgor instantáneo (...) ha entendido por qué, a pesar de su buena voluntad, de sus esfuerzos incluso, desde que llegó de Paris después de tantos años de ausencia, su lugar natal no le ha producido ninguna emoción: porque ahora es al fin un adulto, y ser adulto significa justamente haber llegado a entender que no es en la tierra natal donde se ha nacido, sino en un lugar más grande, más neutro, ni amigo ni enemigo, desconocido, al que nadie podría llamar suyo y que no estimula el afecto sino la extrañeza, un hogar que no es ni espacial ni geográfico, ni siquiera verbal, sino más bien, y hasta donde esas palabras puedan seguir significando algo, físico, químico, biológico, cósmico, y del que lo invisible y lo visible, desde las yemas de los dedos hasta el universo estrellado, o lo que puede llegar a saberse sobre lo invisible y lo visible, forman parte, y que ese conjunto que incluye hasta los bordes mismos de lo inconcebible, no es en realidad su patria sino su prisión, abandonada y cerrada ella misma desde el exterior -la oscuridad desmesurada que errabundea, ígnea y gélida a la vez, al abrigo no únicamente de los sentidos, sino también de la emoción, de la nostalgia y del pensamiento. (LP, p. 90-1)

Quanto ao estilo que forja o autor a partir desse lugar que sua obra cria, também este já parece bem assentado no momento em que surge La pesquisa, tanto no sentido em que o escritor parece muito cômodo e seguro de sua narrativa, como no de que esta já goza do reconhecimento imediato de seus leitores frequentes. Assim, críticos como Julio Premat ${ }^{32}$,

\footnotetext{
${ }^{31}$ Como escritor, afirma Saer em "La selva espesa de lo real" que "[t]odos los narradores viven en la misma patria: la espesa selva virgen de lo real" (1997, 271). Esta passagem, de certa forma, é a contrapartida em um ensaio do trecho abaixo, retirado da ficção.

32 "Así, esa cadencia de escritura, es, en sí, el proyecto, [...] un ritmo que también identificamos en el estilo del escritor, esas largas frases, a la vez extensas, digresivas y de pulso seguro [...]” (PREMAT, 2009, p. 171)
} 
Beatriz Sarlo ${ }^{33}$ e Maria Teresa Gramuglio ${ }^{34}$ podem definir um estilo de narrativa bastante bem marcado - ainda que, por natureza, cambiante - em Saer. Por outro lado, é o próprio escritor, em entrevista a Margarita Merbilhaá, quem comenta sobre a questão do estilo:

Pero el estilo es el hombre mismo, es el hombre, es decir, que el trabajo sobre el estilo para mí estuvo guiado siempre por la lengua oral del Río de la Plata. [...] Y después, una especie de lógica musical que es totalmente personal. Personal no en el sentido de que haya hecho una invención, sino que es una especie de arbitrariedad rítmica que yo me impuse a mí mismo porque me gustaba ese tipo de frase, nada más. (SAER, 2004, p. 9)

Já sobre a gradual diminuição da incidência de diálogos em suas narrativas, Saer contesta à entrevistadora: "Sí, pero depende, por ahí aparece. Al principio, el diálogo es una especie de facilidad. [...] Siempre hay un poco de diálogo, pero no tanto como al principio. Pero también me gustaba escribir esas cosas dialogadas" (SAER, 2004, p. 9).

Por estes fatores soa particularmente interessante a análise que faz Pichón, superficialmente, do tex to anônimo encontrado entre as coisas de Washington (LP, p. 72):

La primera conclusión que ha sacado del examen visual del dactilograma, o de su disposición tipográfica, más bien es que la novela no incluye un solo diálogo, pero después, adentrándose un poco más en el texto, ha podido verificar que, a decir verdad, hay muchísimos, aunque transcriptos siempre en forma indirecta. Las frases son de extensión diferente: a veces hay frases cortas, a veces las frases cortas y las largas alternan, y a veces la extensión de las frases va aumentando, hasta alcanzar la extensión de una o dos páginas, lo que parece dar siempre lugar al punto y aparte. Quienquiera haya sido el autor - hasta este mismo momento en que están sentados a la mesa tomando la primera cerveza de la noche con Soldi y Tomatis no se le ha ocurrido todavía ningún nombre - no da la impresión de adherir, por el uso sistemático de la frase corta, a la superstición de la eficacia ni, por practicar en forma exclusiva los períodos interminables, al barroco de vulgarización. Por un prejuicio favorable, ya que todavía no ha leído la novela, Pichón le

\footnotetext{
${ }^{33}$ Sobre Nadie nada nunca: "la frase tiende a ampliarse mediante intercalaciones que presionan hacia fuera, sobre sus límites. Por otra parte, se repiten frases, tramos de textos, que se conservan, como grumos de significación, para ser desplazados y recolocados” (REALES, L.; PREMAT, J.; MONDRAGÓN, J.C., 2010, p. 16)

34 "A causa de la fuerza de esos elementos constantes que configuran lo invariable y más reconocible de su estilo, tal vez no siempre se haya destacado lo suficiente que cada una de sus novelas ensaya una forma nueva, introduciendo transformaciones en los diversos niveles del relato, sean la extensión, la estructura de la composición, el tono o las voces narrativas" (GRAMUGLIO, 2009, p. 3, grifo da autora)
} 
atribuye al autor desconocido una capacidad de modulación rítmica gracias a la cual cada frase tiene la extensión que le corresponde, basándose en la identificación lo más completa posible de sonido y sentido, y no en principios abstractos de una supuesta estética del relato y una pretendida visión del mundo como le dicen, anteriores al momento de la redacción.

Parece, então, que o estilo do autor de "En las tiendas griegas" se aproxima bastante ao de Saer, ainda que, sobre a identidade do autor do datilograma, ironicamente, a Pichón "não lhe ocorreu ainda nenhum nome".

Outras particularidades de "En las tiendas griegas" causam questionamentos: sua autoria e sua filiação de gênero. A Tomatis lhe parece inconcebível que o texto seja de autoria de Washington, esse personagem tão macedoniano, na boca de quem "la palabra novela [...] tenía siempre un matiz despectivo" (LP, p. 62). Do mesmo modo, para Saer, ainda que talvez sem o tom depreciativo, a palavra "novela" ("romance", em português) é um termo bastante restrito de um gênero circunscrito historicamente e encerrado em fins do século XIX. O que permanece, inerente ao ser humano, é a narrativa, da qual a "novela" (romance) seria uma das manifestações. Assim, o rótulo que "En las tiendas griegas" recebe de "romance histórico" pode, também ser problematizado, com a adição de um outro fator curioso: o de que a novela começa e termina com reticências. Isto, de certa forma - e apesar de suas 815 páginas -, lhe confere o caráter de fragmento, sobre o qual diz Saer que "no posee la autonomía de un género, sino que depende, para existir como fragmento, de su relación con una intención totalizadora, explícita o implícita. El fragmento existe como texto conflictivo, como residuo de una praxis problemática.” (REALES, L.; PREMAT, J.; MONDRAGÓN, J.C., 2010, p. 24) O texto de "En las tiendas griegas", que realmente existe como fragmento dentro da narrativa de La pesquisa, que não possui autonomia dentro da obra de Saer, cumpre sua função, no entanto, como texto conflituoso, dialogando com os outros discursos que se cruzam no romance de Saer e evidenciando, de fato, uma práxis problemática na narrativa do escritor argentino. 
Se a presença de um lugar e um estilo de escrita são marcas fundamentais da narrativa de Juan José Saer, também o é o caráter autorreferencial da linguagem nestas mesmas narrativas. A problemática do ato de narrar transparece nos textos de Saer trabalhada de várias formas, como na representação do tempo. Talvez ilustrado de forma mais célebre e contundente em Nadie nada nunca (2000a), em sua narração de um presente ao mesmo tempo eterno e imóvel, o que esta representação evidencia é uma espécie de impossibilidade de narrar. O único tempo que existe é o presente, mas este, congelado em um instante, é inapreensível. O passado e o futuro confluem para este presente, para sua configuração, sem a possibilidade real de se constituir como narrativa real ${ }^{35}$. O momento em que culmina a narrativa de La pesquisa, com a conversa de Pichón, Tomatis e Soldi no bar, é o único presente possível da narrativa do romance e nele quase nada acontece. E se a sensação de Pichón é a de que Tomatis parece uma figura imperecível "no tanto [por] la mansedumbre del tiempo como [por] su inexistencia", a Tomatis também "únicamente el presente le parece real". (LP, p. 150)

A realidade dos seres nesta narrativa, entretanto, também se modifica. No impasse da impossibilidade de narrar, as pessoas e objetos, descritos, configuram-se não mais do que em imagens, em discursos, em linguagem. Na tentativa de escapar de uma essência da existência que pode ser terrível e intolerável, as pessoas, para o narrador de La pesquisa, preferem agarrar-se a "la apariencia espesa y brillante de las cosas que, por carecer de una nomenclatura más sutil, seguimos llamando reales" (LP, p. 40). O real se simula, mas segue sendo, ainda que espesso e brilhante, só uma aparência.

Para Morvan, que como detetive deve buscar o que há além - ou debaixo - das aparências, o criminoso ainda desconhecido, o "homem ou o que fosse", "era menos una

\footnotetext{
${ }^{35}$ Sobre Nadie nada nunca, afirma Beatriz Sarlo que "la novela desarrolla una 'teoría' del presente, propuesta para representar el movimiento, el suceso, los cambios. [...] Claro está que, cuando el relato elije el presente como su tiempo, descarta el 'avance novelesco', los cambios de situación como su razón" (REALES, L.; PREMAT, J.; MONDRAGÓN, J.C., 2010, p. 14)
} 
persona humana que una imagen" (LP, p. 41); os policiais que o flagram nu e ensanguentado no apartamento da última vítima se parecem a bonecos inanimados; e mesmo "la verdad íntima de su propio ser era [...] inasible" e "su posible inocencia era tan incomunicable y remota como un recuerdo o un sueño" (LP, p. 176, grifo meu).

Em outra passagem, o terminal rodoviário da cidade, inaugurado há mais de dez anos, "Pichón le dice todavía la Terminal Nueva" (LP, p. 135). O mesmo personagem também "fala" com um inseto (a "bailarina") que cai no prato de azeitonas no bar depois de já ter sido importunado por outro inseto (LP, p. 204):

- Ya te advertí cuando tuve que sacarte del bolsillo que no queríamos volver a verte por aquí.

- No es la misma - dice Tomatis, inclinándose sobre el platito de aceitunas.

- Nunca se sabe - dice Pichón -. Y aún así, ¿cuál es la diferencia?

Ou seja, o que simulamos perceber como real - o terminal, o inseto - na verdade se revela como aparências revestidas pela linguagem, por um nome. O lugar, que não é mais "novo" há tempos, para Pichón ainda carrega o epíteto, já que sua percepção do real se reveste com esta linguagem. Por outro lado, o ser vivo que pode ser único, por sua insignificância, não adquire o status suficiente de "realidade" para merecer uma representação verbal que o caracterize dessa forma. A ilusão de transparência e solidez da linguagem, de um sistema perfeitamente adequado ao "real" é posta em cheque não somente por partes ou passagens de La pesquisa, mas denunciada pelo romance como um todo, como sua própria configuração e razão de ser - bem como acontece com toda a obra de $\mathrm{Saer}^{36}$.

\footnotetext{
${ }^{36}$ Ao descrever o toldo do barco em que os personagens fazem o passeio pelo rio, o narrador primário do romance lhe atribui primeiro listras "verdes y blancas" (LP, p. 64 e 65), mas, depois, "amarillas y blancas" (duas vezes na p. 66). Como não tive a acesso a outras edições do livro, além da citada na bibliografia deste trabalho e pelo fato de, na edição brasileira em português, o toldo aparecer sempre "verde e branco" - não me foi possível verificar se tal oscilação teria sido somente um lapso na revisão do texto. De qualquer modo, é interessante pensar em outro lapso: o da linguagem que, longe da transparência e estabilidade ilusórias, oscila na percepção e representação do real.
} 
Por isso, Morvan, não em seu estado de loucura, mas de sobriedade, tem dificuldades em ajustar um discurso à realidade que tenta descobrir e compreender. Já no cenário caótico e estilizado criado pelo assassino ao matar uma das vítimas, analisa que a loucura "ordena el mundo según un sistema de significaciones sin fisuras" (LP, p. 115). Por isto, no apartamento revirado e ensanguentado, no corpo dilacerado e eviscerado, na desordem absoluta da cena, o detetive percebe que "[h]abía casi demasiado sentido". Dentro daquele caos, as coisas pareciam "reintegradas con un signo diferente" e em tudo "quedaban signos legibles de lo que había sucedido" (LP, p. 115). A loucura, portanto, pode se dar ao luxo de prescindir da incerteza e configurar um sistema de significação das coisas absolutamente coeso e sem fissuras. A arte - neste caso, ingênua, diria Saer - também teria essa possibilidade e o gênero policial mais convencional parece se agarrar muitas vezes a esta ilusão. Ali, toda a narrativa guarda elementos concisos que admitem uma, e só uma, significação, que levará à conclusão da história. Estes elementos, todos, revelam signos legíveis de uma narrativa, mas são ao mesmo tempo, claro, reintegrados com um signo diferente, para permitir ao leitor usufruir da intriga de suspense, mistério e jogos de raciocínio. Assim, La pesquisa se revela o romance policial que desnuda o discurso do gênero, fazendo uso - de certa maneira, ao menos - desse mesmo discurso.

Os entrelaçamentos de narrativas dentro de La pesquisa e com outros textos da obra de Saer completam-se, por fim com a intertextualidade estabelecida com outros textos, literários ou não, que podem se manifestar de maneira mais explícita, mais sutil, ou serem simplesmente supostos pelas associações estabelecidas pelo leitor. Observem-se três casos destes procedimentos.

Uma referência intertextual explícita em La pesquisa surge na narrativa primária do romance, quando o grupo volta de barco pelo rio e Tomatis, levantando a voz para que todos possam ouvi-lo, põe-se a recitar os seguintes versos em italiano (LP, p. 88, grifo do autor): 
O frati, dissi, che per cento milia perigli siete giunti a l'occidente, a questa tanto picciola vigilia d'i nostri sensi ch'è del rimanente non vogliate negar l'esperïenza, di retro al sol, del mondo sanza gente. Considerate la vostra semenza: fatti non foste a viver come bruti, ma per seguir virtute e canoscenza.

Estes versos, pertencentes ao Canto XVI, do Inferno da Divina Comédia de Dante Alighieri, retratam o discurso de Ulisses dirigido a seus companheiros no intuito de animá-los para o enfrentamento dos perigos no mar, em busca do conhecimento - de novas terras, novos mundos, do novo, enfim. O caráter histriônico da cena é coerente com a construção de Tomatis como personagem nos diversos textos em que aparece na obra de Saer, mas o discurso que este profere estabelece um diálogo intertextual direto com o momento que se desenrola na narrativa de La pesquisa. Também Tomatis, Pichón e Soldi estão em um barco, também eles estão em uma jornada em busca do conhecimento - o misterioso datilograma na casa de Washington -, também eles enfrentam perigos e dificuldades - a resistência e antipatia de Julia, filha do antigo mentor e guardiã do texto, que pode deixá-lo fora do alcance dos que tanto se interessam por ele. Além disso, a passagem de Dante é, ela mesma, um exemplo de intertextualidade, estabelecendo um diálogo com a Odisséia através de personagens e situações. Por fim, esta referência "em segundo grau" ao mudo mítico grego se une ao livro de mitologia de Morvan e, por sua vez, a todo o imaginário da loucura que o acomete - ou que, em todo o caso, Pichón lhe atribui em sua narrativa.

Um segundo exemplo de intertextualidade a partir de textos externos ao universo saeriano de maneira restrita, por assim dizer, vem no comentário de Tomatis sobre o inseto que agoniza no pratinho de azeitonas, na cena já mencionada: "Su hora sexta". Mesmo sendo mais sutil e menos carregada de significados e desdobramentos que a comentada 
anteriormente, a passagem pressupõe, além da linguagem corriqueira, um contexto cultural também associado à palavra: o suplício e morte de Jesus, tal como referido no Evangelho de Mateus: "Entre a hora sexta e a hora nona houve treva em toda a terra" (Bíblia de Jerusalém, Mateus 27:45). Este episódio de La pesquisa (p. 205) fecha, por fim, a narrativa do romance, que se encerra na página seguinte: é também a "hora sexta" da narrativa - mesmo que só no romance e não na narrativa contínua de Saer em sua obra.

Outros casos de intertextualidade no romance são o comentário que faz Tomatis sobre a reivindicação de verdade do relato que faz Pichón - "Es un lugar común de la crítica francesa" (LP, p. 141) - e as possíveis alusões ao início das Soledades de Góngora nas menções ao mito do rapto de Europa por Zeus, associado à precisão do tempo em que se situa o relato. O último caso que se verá aqui, entretanto, é mais uma suposição de leitura baseada na intertextualidade que uma referência concreta e explícita. Segundo o narrador, depois da antipatia imediata entre Julia e os velhos amigos de seu pai, um deles, Cuello, rompe definitivamente relações com ela, a quem só se refere a partir de então como "esa mujer" (LP, p. 59). A recusa a se referir à mulher por seu nome pode remeter o leitor - ou, ao menos, foi o meu caso - a duas referências bastante díspares, na verdade. A primeira seria retirada do primeiro conto de Conan Doyle sobre Sherlock Holmes, "Escândalo na Boêmia" (2010b, p. 71-108), no qual a personagem Irene Adler consegue ludibriar o famoso detetive. A partir de então, segundo Watson, o narrador, Holmes só se refere a ela como " $a$ mulher". Este caso, que também envolve a intenção da mulher em manter a posse de documentos a que outros desejam ter acesso - como o manuscrito de Washington -, foi também o único em que o detetive fracassou, ainda que seu fracasso não pareça resultar, ao fim, trágico ou tenha maiores consequências. Apesar da coincidência do gênero policial entre La pesquisa e "Escândalo na Boêmia", a segunda referência parece mais próxima de Saer, inclusive pela mesma nacionalidade dos autores: o conto "Esa mujer", de Rodolfo Walsh (2001). Neste 
texto, aquilo a que não se tem acesso não é um texto, mas o corpo da mulher - Evita Perón, nunca mencionada por seu nome. O coronel, com quem dialoga o escritor e jornalista narrador da história, no entanto, estaria, por sua vez, interessado em "papéis" que talvez o jornalista tenha. Como em La pesquisa e "Escândalo na Boêmia", as expectativas de acesso ao que se quer se veem frustradas.

Resta, por fim, a esta análise o exame da relação de La pesquisa, não com um texto em especial, mas com todo um gênero: a narrativa policial. Em outras palavras, falta analisar como o discurso do romance se relaciona com o discurso de todo um gênero e o que supõe esse relacionamento, que é o que se verá a seguir.

\subsection{La pesquisa como narrativa policial}

Se modernamente a obra literária com pretensões artísticas - a dita "alta literatura" -, não se enquadra sem problemas e questionamentos - inclusive internos à própria obra - na noção de gênero, a obra literária de entretenimento - ligada à cultura de massa e à indústria cultural - adere-se firmemente a uma série de rígidas regras e procedimentos que, no fim das contas, garantem seu valor como literatura de massa. Nas palavras de Todorov, "a obra-prima da literatura de massa é precisamente o livro que melhor se inscreve em seu gênero" (2003a, p. 65). Daí decorre o esforço por parte de muitos escritores e críticos - Chesterton, Narcejac, Poe, Van Dine e mesmo Borges - em definir, da maneira mais estrita possível, as "regras" do gênero policial. Tais regras, que, de acordo com cada autor, variam consideravelmente, são ao mesmo tempo tantas e tão taxativas, que acabam por criar um paradoxo: muitos romances, por exemplo, poderiam ser classificados como pertencentes ao gênero policial se levássemos em conta que cumprem em sua estrutura com apenas alguns dos "critérios" do gênero - a presença de um crime e de sua investigação, por exemplo. E aí seria possível encontrar 
autores que arrolem o episódio do velho da bengala no Quijote de Cervantes, ou a história bíblica de Susana - no Livro de Daniel - no gênero policial ${ }^{37}$, a despeito da contrariedade dos que consideram o gênero estritamente atrelado à literatura de massa. Por outro lado, cumprir com todas as regras formuladas por todos os críticos seria impossível, já que muitas vezes elas se contradizem. Outro caminho, o de seguir estritamente o conjunto de regras formulado por um desses críticos, também resultaria inócuo, já que, por mais que literatura de massa tenda à convenção e não tome o "novo" - no sentido de inovação estética - como critério de valor, a impossibilidade de qualquer alteração no esquema inviabilizaria novas obras. Ainda que, citando novamente Todorov, o melhor romance policial seja "aquele sobre o qual nada se tem a dizer" (2003a, p. 65), não se pode chegar ao paradoxo de que o melhor romance policial seja aquele que já não possa mais ser escrito nem lido.

Para tomarmos La pesquisa como romance policial, então, o que primeiro se deve fazer é descartar quaisquer das classificações do gênero baseadas no esquema "as dez - ou vinte, ou quinze - regras do romance policial". Se considerássemos as arqui-conhecidas regras elaboradas por S. S. Van Dine, por exemplo - comentadas por Albuquerque (1979, p. 23-34) e também mencionadas por Todorov (2003a, p.72) -, já encontraríamos problemas: segundo duas das regras de Van Dine, o culpado jamais deve ser o detetive e não há lugar para descrições nem para análises psicológicas, duas regras claramente quebradas em $L a$ Pesquisa.

É, de qualquer modo, como já mencionado, o próprio Saer quem considera o romance uma narrativa policial, ainda que adaptada "à sua maneira", o que chegou, segundo ele, a lhe custar certo trabalho. O primeiro artifício usado por Saer no romance para introduzir o gênero policial em sua "maneira" narrativa chega a ser banal: um personagem recorrente da obra saeriana, Pichón, narra a amigos a história de uma série de crimes, sua investigação e

\footnotetext{
${ }^{37}$ Como o faz Rodolfo Walsh, em "Dois mil e quinhentos anos de literatura policial” (2011, p. 221-5).
} 
elucidação. O relato policial se insere pela transmissão oral ${ }^{38}$ que ocorre na região de Santa Fé criada por Saer como a zona - ou a cadência, ou a maneira, ou o território - de criação e desenvolvimento de toda sua obra. Os desdobramentos do relato de Pichón, as reações que provoca, a função que assume dentro da narrativa maior do romance, vão, entretanto, muito além do banal.

Segundo Silviano Santiago, “[a] literatura latino-americana de hoje nos propõe um texto e, ao mesmo tempo, abre o campo teórico onde é preciso se inspirar durante a elaboração do discurso crítico de que ela será objeto" (2000, p. 26). Curiosamente, parece ser este o caso não só da obra de Saer como um todo, mas como o do relato policial de Pichón dentro de La pesquisa. Sua história dos assassinatos de velhinhas em Paris, cheia de convencionalismos do gênero policial, não deixa, de um modo ou de outro, de provocar reações em seus amigos que a escutam: Soldi, a quem o relato "ha empezado a interesarle" (LP, p. 155) e, principalmente, Tomatis, que a todo momento interrompe o relato de Pichón, questionando seu valor e, supostamente, seu convencionalismo - "Suspenso barato" (LP, p. 133).

A discussão literária, comum entre os personagens de Saer também em outras narrativas suas, se apresenta em La pesquisa em torno a dois eixos principais: os problemas sobre a questão do gênero - que o próprio Saer levantava em artigos como "Razones"39 ou, coincidentemente, "Dos razones" 40 - e da representação literária do real.

Quanto ao gênero, logo após a passagem citada acima, Tomatis afirma, ironicamente, com a boca cheia da pizza quente que comiam: "Toda cocha debe cher perfechta en chu hénero" [“Toda cosa debe ser perfecta en su género.”] (LP, p. 135). Depois de condenar os supostos convencionalismo e trivialidade da história contada por Pichón, praticamente repete

\footnotetext{
${ }^{38} \mathrm{Ou}$, como se viu, pelo artifício de uma instância narrativa primária - o protonarrador saeriano - de simular a oralidade no relato de seu personagem.

${ }^{39}$ Presente em Crítica Cultural = Cultural Critique (Edição especial - Dossiê Juan José Saer) (REALES, L.; PREMAT, J.; MONDRAGÓN, J.C., 2010, p. 19-31)

${ }^{40}$ Em La narración-objeto (1999, p. 157-61)
} 
a consigna presente em regras ditadas como as de Van Dine. A ironia de Tomatis, aplicada ao relato do amigo, na verdade pode ser extrapolada ao romance de Saer em si mesmo, tão imperfeito dentro do gênero policial. Na verdade, mais do que irônica, a imperfeição genérica do(s) texto(s) - o romance La pesquisa como um todo e o relato policial de Pichón dentro deste - leva a uma consideração um pouco mais profunda: a de como o gênero se estabelece também pela sua transgressão ${ }^{41}$.

Para determinar como a ideia de transgressão estabelece, na verdade, os limites do gênero, apelemos ao que afirma Foucault, em seu "Prefacio a la transgresión" (1999, p. 167):

La transgresión es un gesto que concierne al límite [...] El límite y la transgresión se deben mutuamente la densidad de su ser: inexistencia de un límite que no podría absolutamente ser franqueado y vanidad a cambio de una transgresión que no franquearía más que un límite de ilusión o de sombra. Pero, ¿tiene el límite una verdadera existencia fuera del gesto que gloriosamente lo atraviesa y lo niega?

Assim, é possível se estabelecer que a transgressão ao limite é o que verdadeiramente lhe confere existência. No caso presente, a transgressão do gênero policial delimita o próprio gênero no relato de Pichón e no romance em si. Transgredir os limites do policial confere a $L a$ pesquisa um caráter particular dentro do gênero de que participa e que ajuda a configurar. Por outro lado, a transgressão de Saer, ao abandonar - em parte, ao menos - o espaço diegético tradicional da maioria de suas obras e ao, ainda que condenando em diversos ensaios a pobreza artística da literatura de massa ${ }^{42}$, lançar-se ao gênero policial em um romance, reforça também a coerência da obra de Saer. O que a primeira vista parece paradoxal - um "arauto" da alta literatura, reflexiva, problematizada em sua escritura e na representação da realidade, abraçar um gênero popular, como o policial - converte-se em mais uma oportunidade para a

\footnotetext{
${ }^{41}$ Para Julio Premat, em La dicha de Saturno, o romance, na verdade, "retoma una variante transgresiva del código que las novelas policiales utilizan a menudo: el que cometió el crimen es alguien que, por la deontología de su posición o según las reglas del género, no puede ser el criminal [...]” (2002, p. 355)

${ }^{42}$ Exemplos são vários dos ensaios incluídos em El concepto de ficción (1997): "El concepto de ficción", "Literatura y crisis argentina", "La novela", "Una literatura sin atributos", etc.
} 
reflexão sobre a literatura, o conceito de gênero, a obra do autor, o eterno problema para Saer - mas não só para ele, obviamente - do estatuto do real e da ficção.

\section{O real e o fictício, representações e traduções}

Na definição de Martín Prieto (2006, p. 415), por exemplo, a obra de Saer "pone en crisis la confianza en la posibilidad de representación de lo real, como si convocara, para poner en evidencia su ineficacia, la retórica de la representación realista”. Indo além, seria possível não só definir a problemática central de sua obra como a virtual impossibilidade de representação do real, como também apontar a discussão desse problema como uma temática comum dessa mesma obra. Em outras palavras, os personagens de Saer, como em La pesquisa, discutem o estatuto do real dentro da narrativa ficcional em uma operação que tem algo (ou muito) de metalinguístico. A narração em abismo se multiplica dentro do romance: um primeiro narrador narra a viagem de Pichón à cidade natal, onde este narrará aos amigos a trama policial; esta trama, por sua vez, vem da narrativa lida nos jornais parisienses, segundo a alegação de Pichón; Soldi narra a história de "En las tiendas griegas", manuscrito apócrifo encontrado entre as coisas de Washington - outro personagem habitual saeriano - após sua morte; os personagens dentro de cada narrativa narram suas próprias histórias. A referência do real, assim, se torna inatingível.

No sentido contrário, no entanto, outra operação se realiza: cada personagem questiona a própria narrativa de que faz parte. Os soldados de "En las tiendas griegas" discutem a validade das experiências, reais e fictícias; Morvan - o detetive da trama policial medita sobre sua imputabilidade na série de crimes; Tomatis ironiza o valor do relato do amigo - para, enfim, refutá-lo. Todos esses questionamentos acabam buscando, na verdade, 
algum referencial no real em que se apoiar, mesmo que o resultado desta busca se mostre, ao fim, infrutífero.

A desconcertante conclusão da busca por referenciais é que eles só são encontrados, na narrativa, em outras narrativas. Os fatos e personagens históricos da guerra de Tróia só chegam ao conhecimento do Soldado Velho - que havia passado dez anos no centro dos acontecimentos, no cerco à cidade de Tróia - pelo relato do Soldado Jovem, que acaba de chegar ao acampamento grego, mas conhece todas as histórias e heróis pelos lendários relatos que ouvira. Morvan crê ter chegado ao assassino por meio de uma carta - ainda que rasgada e revisa todos os relatórios em busca da identidade do criminoso real. Pichón defende o valor de sua história perante Tomatis bradando a autoridade dos jornais, além da sua proximidade dos fatos: "Salió en todos los diarios. Y además pasó a la vuelta de mi casa." (LP, p. 141). A autoridade da narrativa atestada por outras narrativas não é, obviamente, uma invenção de Saer, mas, e aqui vale notar, é um artifício comum presente no gênero policial, de Poe a Borges. Especificamente a imprensa diária parece carregar essa autoridade de "verdade": o que está nos jornais se corresponde totalmente aos fatos e personagens do mundo empírico. Como aceitar tal constatação exige um grau de ingenuidade que não se pode atribuir a Saer, a Borges ou a Poe, cabe verificar o propósito do uso de tal artifício.

Em “Sobre el género policial”, artigo de 1976 publicado em Crítica y ficción, Ricardo Piglia afirma, sobre o gênero policial e o jornalismo: “Auden decía que el género policial había venido a compensar las deficiencias del género narrativo no ficcional (la noticia policial) que fundaba el conocimiento de la realidad en la pura narración de los hechos." (2001, p. 60) Auden, segundo Piglia, faz tal afirmação partindo de Edgar Allan Poe como fundador do gênero no século XIX, mesmo ponto de partida que é tomado aqui, ou seja, os contos "Os crimes da Rua Morgue", "O mistério de Marie Rogêt" e "A carta roubada", de 1841,1842 e 1844 respectivamente. 
Já nessas três narrativas inaugurais do gênero estabelece-se um de seus pilares: o gênero policial constitui uma narrativa sobre uma narrativa. A partir do crime, anterior ao início da narração, constrói-se uma narrativa que o elucida e é este o material que constitui o conto ou o romance. $\mathrm{O}$ narrador, muitas vezes amigo do detetive, conta a história que este desenvolve para chegar à elucidação do mistério. Fora isso, há pouca ação no tempo lógico em que se desenrola a trama. Assim, em "Os crimes da Rua Morgue” (POE, 1961), o narrador narra basicamente o raciocínio de Dupin para se chegar ao criminoso responsável pelos hediondos assassinatos. Neste esquema, o jornal surge pela primeira vez com uma importância fundamental.

Como o crime é anterior ao início da narrativa e o detetive e seu colega pouco agem para ter algum acesso direto ao fato (pistas, testemunhos), o acesso à "realidade" do crime se dá, primeiramente e em grande medida, por meio dos relatos da imprensa. Os jornais são, portanto, a fonte dos fatos, a realidade empírica se conforma como uma narrativa a partir da qual se desenvolve a narrativa interna de Dupin na elucidação do crime.

Em “O mistério de Marie Rogêt” (POE, 1961) o procedimento se aprofunda. Em uma nota de rodapé no início do texto, afirma-se que o conto foi escrito a partir dos dados encontrados pelo seu autor - que "não esteve presente ao local do crime" - em notícias de jornais. Também na mesma nota lê-se que: “[...] todo argumento baseado na ficção é aplicável à verdade e a investigação da verdade foi o objetivo." (POE, 1961, p. 38). Chama a atenção aqui a vindicação da "verdade" do texto - lembremo-nos, baseada em notícias de jornal.

Já em "A carta roubada" (POE, 1986), o processo se inverte. A "verdade dos fatos" chega a Dupin através do relato do chefe de polícia sobre o roubo da carta. A principal motivação para a descoberta de seu paradeiro é evitar que seu conteúdo seja divulgado, publicado. O escândalo do crime deve ficar longe dos jornais. 
Da mesma maneira que se imputam a estes três contos de Poe não só a gênese do gênero policial, mas também todas as bases sobre as quais o gênero se desenvolveria - o narrador testemunha, o detetive exótico e reflexivo, o processo analítico -, também neles se desenvolvem as visões sobre a imprensa que permearão o policial daí em diante: o relato jornalístico como fonte de verdade - "Os crimes da Rua Morgue" -; a verdade dos jornais relativizada - nas inúmeras versões dos fatos presentes nos inúmeros jornais mencionados em “O mistério de Marie Rogêt" -; e a manipulação - política, social - da verdade da qual a imprensa pode ser instrumento, como em "A carta roubada". Mas que "verdade" é essa que se investiga no texto?

Saer, em "El concepto de ficción" (1997a, p. 9-17), afirma que "el rechazo escrupuloso de todo elemento ficticio no es un criterio de verdad" e que, portanto, "la verdad no es necesariamente lo contrario de la ficción". Esta é a mesma discussão que volta a aparecer em forma de ficção em La pesquisa, no diálogo entre Pichón e Soldi sobre a história do Soldado Velho e do Soldado Jovem em "En las tiendas griegas”(LP, p. 146).

O ponto central de La pesquisa - a pesquisa, a investigação da verdade - está aí: não na descoberta da verdade empírica por meio da ficção, mas na descoberta - aqui inclusive no sentido de revelação - da verdade da ficção ${ }^{43}$. A busca de Saer por sua zona, sua cadência, sua maneira de narrar, como o formula Julio Premat, é também uma busca por uma verdade ficcional $^{44}$. A construção de seu mundo, que, se não é o empírico, não é menos verdadeiro, não é uma tarefa simples para Saer, como não o é para nenhum escritor que compartilhe, ao menos em parte, de suas ideias sobre a literatura e o ato de escrever. Nesse mundo literário, a

\footnotetext{
${ }^{43}$ Curiosamente, o romance La pesquisa foi publicado em Portugal em 2002, pela Editorial Caminho, com o título A Investigação, que na realidade parece mais adequado, não só como tradução literal, como também ao teor da narrativa.

${ }^{44}$ Premat, no capítulo "Saer: un escritor del lugar" de Héroes sin atributos afirma: "Más que de obra o de saga, el conjunto de los relatos escritos por Juan José Saer podría calificarse de cadencia, es decir que esos textos se caracterizan por una frecuencia de producción, por una singular manera de avanzar, por un ritmo, por una continuidad que se prolonga de título en título. [...] aunque los relatos de Saer vayan integrando variantes, innovaciones, transgresiones del propio principio de construcción, una frase lleva a la otra, una página a la siguiente, una novela a su continuación futura." (2009: p. 168-9)
} 
confluência de sentido entre os termos "construir" e "traduzir", por exemplo, vale ser analisada.

\section{Traduções entre discursos entrelaçados}

Mauricio Mendonça Cardozo, em seu artigo “Tradução e o trabalho de relação: uma poiética da tradução", define a tradução como "[u]m trabalho de relação, no sentido de um trabalho que tem lugar no fazer, na construção da relação (das relações), um trabalho que tem lugar na poiesis, como poiesis da relação.” (2009, p. 181, grifo do autor)

$\mathrm{Na}$ trama de La pesquisa, não somos confrontados diretamente com o ato da tradução ${ }^{45}$, mas ao menos em um momento é claro o trabalho de criação, de construção de uma relação, conforme a definição de Cardozo: quando Pichón conta aos amigos a história parisiense a partir dos relatos dos jornais franceses. Toda a sua narrativa - a narrativa do personagem dentro da instância narrativa primária - é um trabalho de relação, é, portanto, tradução. Por outro lado, os personagens - e nós, leitores - se deparam com o datilograma apócrifo encontrado na casa de Washington. Poderia ser este texto - afinal dele nada se sabe também uma tradução ${ }^{46}$ ? De todo modo, "En las tiendas griegas" trata de um tema longínquo no tempo e no espaço: a guerra entre gregos e troianos. Por fim, o mundo fantasioso e terrível dos delírios sonâmbulos de Morvan também pede - por parte do próprio personagem, inclusive - uma tradução a seu mundo empírico, pede um trabalho de relação ${ }^{47}$.

O termo "traduzir" ou algum de seus correlatos aparece, de todo modo, em algumas poucas passagens do romance: quando se mencionam as esporádicas traduções de livros de

\footnotetext{
${ }^{45}$ Uma pequena exceção seria a menção a traduções esporádicas que Julia, filha de Washington, fazia de livros de medicina. (LP, p. 58)

${ }^{46}$ Tomatis chega a dizer: "No tiene porque ser un autor local" (LP, p. 148).

${ }^{47}$ A cidade fantasmagórica dos sonhos de Morvan, em muito se parecia com qualquer cidade conhecida - com a Paris do detetive - mas causava inquietação, por exemplo, por seu "silencio desmedido" e "ciertos problemas de legibilidad" (LP, p. 28-9)
} 
medicina que faz Julia (LP, p. 58); quando Soldi pensa que quando falam entre si Tomatis e Pichón "tiene que someterlos a una especie de traducción” (LP, p. 56); quando um gesto de Tomatis pode ser "traduzido" em palavras, em uma declaração verbal - "un movimiento de cabeza significativo que, traducido a palabras podría decir [...] (LP, p.134) -; e quando o narrador, ao descrever o macabro ritual do assassino, o atribui a "la lógica del delirio, únicamente válida para el que había elaborado el sistema, e intraducible a cualquier idioma conocido" (LP, p. 42, grifo meu).

Nos dois últimos casos, a "tradução" de uma realidade - banal no caso do gesto, terrível no da lógica delirante de um assassino - em palavras é impossível. Mas também, a tentativa de comunicar, a relação que se tenta construir entre dois discursos - e entre os portadores desses discursos - é árdua. O próprio narrador de La pesquisa constata esta dificuldade - ou esta impossibilidade: "No sé si se dan cuenta de lo que estoy tratando de decir" (LP, p. 154). Por outro lado, tenta formular - ou simular, como seria mais apropriado dizer - uma maneira de superá-la: "estoy empleando su propio vocabulario" (LP, p. 164). Constatar esta solução como simulacro é, a este ponto, simples: sabemos que o narrador Pichón não tem como "traduzir" fielmente o discurso do criminoso ou o do detetive. Sabemos, inclusive, que o próprio discurso de Pichón é um simulacro produzido por outra instância narrativa, anterior, primária.

Os discursos que se entrelaçam não serão nunca transparentes, posto que intraduzíveis entre si - ou, invertendo a lógica, nunca poderão ser realmente traduzidos, já que não são nunca transparentes. Falando de Tomatis, Pichón e Soldi, o próprio protonarrador saeriano, desta constatação, apresenta seu corolário (LP, p. 202-3):

Los tres tienen residuos de las sensaciones que han experimentado a lo largo del día caliente y luminoso, y el paseo por el río, la visita a Rincón Norte, los vericuetos de islas desteñidas y de agua, les dejará seguramente a los tres recuerdos propios, salidos de una experiencia común, pero intraducibles a los idiomas privados de los otros, y que los acompañarán hasta la muerte. 
O que faz Saer em todo o romance, o que faz em toda sua obra, o que crê que deve fazer todo escritor é isto: encontrar, traduzir e criar sua verdade em sua ficção, a partir de resíduos intraduzíveis, de verdades incomunicáveis. As pistas, os indícios, que na narrativa policial tradicional levam ao criminoso, em La pesquisa levam à narrativa mesma.

Por isso, as relações necessárias para construir um relato na "forma que lhe é própria" representam, em La pesquisa, um duplo desafio: como conciliar o gênero policial e o "gênero saeriano", a cadência ou maneira de narrar de que falava Premat? Que traduções se fazem necessárias? Segundo Edgardo Berg, em "La escuela del crimen” (2008b):

Las formas de distanciamiento, traslado o "traducción" de una forma y un modelo extranjero será postulado, en su forma más extrema, como un imperativo de nacionalización. Los mejores intentos en nuestra literatura hacen que el uso de las convenciones narrativas del género y de las reglas del mismo no se reduzcan, simplemente, a la simple transposición de códigos, figuras y estereotipos.

Extrapolando a interpretação de Berg - na verdade aplicando-a a um caso específico -, percebe-se que a "tradução" do modelo estrangeiro, o gênero policial, é postulada no caso de La pesquisa não como um "imperativo de nacionalização", algo que certamente abominaria Saer, mas como um imperativo de adequação à "maneira narrativa" saeriana, nas palavras do próprio autor. De fato, para além da "mera transposição de códigos, figuras e estereótipos", o que Saer consegue é, a partir de seu cuidadoso trabalho de relação, produzir uma narrativa que não só se adapta à sua "maneira" como também acrescenta a ela um novo elemento, coerente com a totalidade de sua obra. 


\title{
Capítulo 2
}

\section{Ricardo Piglia e Plata quemada}

\author{
- Há uma coisa especial em relação a dinheiro - continuou. \\ - Em grandes quantidades tende a ter vida própria, \\ até uma consciência própria. \\ Fica muito difícil se controlar o poder do dinheiro. \\ O longo adeus, Raymond Chandler
}

O romance Plata quemada, de Ricardo Piglia começa narrando a história de um roubo violentíssimo ocorrido em San Fernando, na província de Buenos Aires, desde seus preparativos até a fuga dos criminosos ao Uruguai, onde se refugiam em um apartamento com o dinheiro do roubo e sofrem o cerco das polícias uruguaia e argentina. A história culmina com os bandidos, que se negam a se entregar, queimando o dinheiro e sendo mortos - com a exceção de um deles - pela polícia. O texto se inicia dando a impressão ao leitor de que este está diante de um narrador onisciente em terceira pessoa - típico do romance policial da vertente dura, hardboiled, norte-americana - que apresenta os personagens centrais do romance - o Gaucho Dorda e o Nene Brignone $\left(\mathrm{PQ}^{48}, 1998\right.$, p. 11):

Los llaman los mellizos porque son inseparables. Pero no son hermanos, ni son parecidos. Difícil incluso encontrar dos tipos tan diferentes. Tienen en común el modo de mirar, los ojos claros, quietos, una fijeza extraviada en la mirada recelosa. Dorda es pesado, tranquilo, con cara rubicunda y sonrisa fácil. Brignone es flaco, ágil, liviano, tiene el pelo negro y la piel muy pálida como si hubiera pasado en la cárcel más tiempo del que realmente pasó.

O narrador que lemos aqui não está muito distante, então, do de Dashiell Hammett no início de O falcão maltês (2001a, p. 7):

\footnotetext{
${ }^{48}$ A sigla PQ será usada nesta tese para as referências e citações de Plata quemada de acordo com a edição usada neste trabalho e citada na bibliografia.
} 
$\mathrm{O}$ maxilar de Spade era largo e ossudo, seu queixo era um $\mathrm{V}$ muito pronunciado, abaixo do $\mathrm{V}$ mais suave, formado pela boca. As narinas se arqueavam para trás para formar um outro $\mathrm{V}$, menor. Os olhos amarelocinzentos eram horizontais. $\mathrm{O}$ tema do $\mathrm{V}$ era retomado pelas sobrancelhas um tanto peludas que se erguiam a partir de duas rugas gêmeas acima do nariz adunco, e o cabelo castanho-claro tombava - de suas têmporas altas e retas - em uma ponta, por cima da testa. De modo bem ameno, ele parecia um satã louro.

No entanto, conforme avança a narrativa do romance, desestabiliza-se o narrador onisciente do início da trama e dúvidas e ambiguidades acerca do que acontece (ou aconteceu) vão surgindo. Não só o narrador primeiro mostra que sua onisciência é falha e falsa, como outras vozes ou instâncias narrativas irrompem na trama e fazem do mosaico de histórias e versões do fato principal narrado o procedimento fundamental pelo qual o romance se constitui. Admitindo-se tal premissa, é necessária a demonstração e análise de como isto ocorre na construção do romance com relação ao gênero policial.

\subsection{Quem narra Plata quemada?}

Sobre a realidade dos fatos, já que Plata quemada estaria baseado em uma historia real, e sobre como essa realidade se converte em narrativa, Julio Premat comenta que: "En Plata quemada esa realidad es polifónica (es una "selva de voces")" (2009, p. 208). Já Michelle Clayton, em "Cómo habla la plata" (PÉRSICO, 2004, p. 135-44) afirma que "[1]a novela está constituida por el entretejido de fuentes, por una multitud de voces diferentes, frecuentemente contradictorias, que cuestionan - implícita y explícitamente - los límites entre la verdad y la ficción, o entre la verdad y su reconstrucción hermenéutica.” (p. 135)

Das "vozes" que narram a historia, Premat identifica as de três personagens que "refletem, em abismo, a produção do texto" (2009, p. 211): Emilio Renzi - jornalista, repórter, investigador e espécie de alter ego recorrente nos textos de Piglia -; Roque Pérez - o 
radiotelegrafista que "escuta vozes" dentro do apartamento onde os criminosos resistem ao cerco da policia -; e o Gaucho Dorda - que nos apresenta a versão pessoal, delirante, quase onírica e, no entanto, não menos "verdadeira" que as demais, dos fatos. Por outro lado, Clayton - citada, inclusive, por Premat em seu artigo - percebe também no personagem Malito outra imagem de autor ${ }^{49}$, já que é ele quem faz os planos do roubo, quem "arma a cena" e quem, assim, "escreve a historia" no fim das contas. Por fim, ambos destacam a figura do narrador no "Epílogo", este "Ricardo Piglia" que nos conta a historia da historia, a descoberta do fato real inspirador, o desenvolvimento da escritura ${ }^{50}$, e nos propõe um "tramposo pacto realista" - nas palavras de Premat - ou uma "sospechosa postulación de verdad" - nas de Clayton. Avançando nas ideias propostas por Premat, é possível esmiuçar como o mosaico narrativo pode ser ainda mais fragmentado e como os sentidos sugeridos por essa fragmentação podem ser ainda mais profundos e intimamente relacionados à essência do romance - como, de fato, já o havia proposto Michelle Clayton - "En gran parte, el espesor de Plata quemada deriva precisamente de la superposición de voces y versiones coexistentes, del entretejido de lo marginal con lo central, de lo no cuantificable y oral con lo autoral y la escritura." (PÉRSICO, 2004, p. 136) -, além de analisar suas relações com questões de gênero e com a obra do próprio autor.

Se, por exemplo, Emilio Renzi tem lugar especial como um destes narradores em abismo que bem nota Premat, o certo é que os jornais em geral têm uma importância fundamental na construção da narrativa a partir das palavras do narrador inicial - aquele que as usa como "álibi" para o que, sugere, não pode narrar. As palavras dos jornais reproduzidas direta ou indiretamente pelo narrador inicial chegam ao leitor muitas vezes como uma reprodução da realidade dos fatos, outras como versões falhas desta mesma realidade, outras

\footnotetext{
${ }^{49}$ Afirma Clayton: "Si bien el narrador está ausente desde el comienzo de la novela, existe sin embargo un autor. Un inverosímil personaje llamado Malito es a quien se le adjudica no sólo la historia narrada sino también la autoría de los mismos acontecimientos [...]"(PÉRSICO, 2004, p. 137)

50 “Al mismo tiempo, e inesperadamente, el Epílogo introduce al escritor en la escena ficcional, introduce otro relato, el del 'encuentro' con la historia [...]” (PREMAT, 2009, p. 211)
} 
ainda como uma manipulação dela. O procedimento de narrar a parir do relato da imprensa, então, contribui com a "superposição de vozes e versões coexistentes" ao mesmo tempo em que aponta para uma das estratégias mais antigas e recorrentes do gênero policial.

\section{As notícias dos jornais}

Depois do início em que se apresenta um narrador onisciente tradicional, já no segundo capítulo, que narra o roubo e a fuga dos criminosos, começam a surgir versões confusas e contraditórias do que aconteceu. O próprio narrador primeiro começa a lançar mão de uma estratégia para narrar: o que disseram os jornais sobre o roubo? Assim, da onisciência literária, passa-se à autoridade da imprensa como estratégia narrativa. Este procedimento, longe de sanar as lacunas de informações na trama, colabora para a ambiguidade da narrativa. A insegurança sobre o que se vai descobrindo da história, no entanto, já não é propriamente culpa do narrador: "La confusión indescriptible que el alevoso ataque produjo no permitió, en los primeros momentos, precisar lo que había ocurrido (decían los diarios)” (PQ, p. 41, o grifo é meu).

As expressões "según los diarios / los periodistas", "dijeron / decían / dicen los diarios" e outras de teor semelhante aparecem abundantemente no texto ${ }^{51}$, especialmente até a descoberta dos criminosos em Montevidéu e o cerco ao apartamento da rua Julio Herrera y Obes. Algumas vezes, tais expressões se configuram como um mecanismo do qual lança mão o narrador primeiro para justificar sua própria narrativa, que não dispõe de todos os dados da trama e dos personagens. Dada a falha na onisciência do narrador com respeito à personagem

\footnotetext{
${ }^{51}$ Além do trecho presente no parágrafo anterior, é possível citar (sempre com grifo meu): “[...] el testigo no llegó a reconocer ninguna cara (dijeron los diarios)." (PQ, p. 36); "De este modo (según los diarios) pudo saberse cómo fue planeado el atraco a los pagadores de la comuna." (PQ, p. 87); "Como detalle ilustrativo de la peligrosidad de los asaltantes (dicen los diarios) [...]”(PQ, p. 54); “[...] la noticia había rebotado en la tele, como una prueba (según los periodistas) de que los delincuentes estaban dispuestos a jugar con la vida de todos [...]"(PQ, p. 161). Estas expressões, e outras de sentido semelhante, aparecem ainda nas páginas 44, 53, 56, 88, $90,91,117,121,130,163,192$ e 193.
} 
de Blanca Galeano, por exemplo, o narrador começa a descrevê-la assim: "Blanquita Galeano, la concubina de Mereles es (según los diarios) una jovencita de clase media [...]” (PQ, p. 88). Uma instância narrativa primária segue presente, mas a autoridade sobre a personagem é transferida para os jornais. Em outros casos, está claro que quem narra é o jornal, e não o narrador primeiro, deixando-se assim a instância narrativa primária e passando-se à narrativa em abismo através de instâncias secundárias - as muitas vozes que comporão o romance. É o que acontece quando se inicia um parágrafo deste modo: "Anoche, al cierre de esta edición, [...]"(PQ, p. 56, grifos meus). Além da "impresión de permanente simultaneidad" conferida ao texto pela forma jornalística, como aponta Clayton (PÉRSICO, 2004, p. 136) - ressaltada aqui pelo "anoche" - é de se notar que a narrativa menciona "esta edição", como se o leitor estivesse lendo diretamente o jornal. Em outro caso, ainda mais amplo, em que se tem a impressão de se estar diante de outra instância narrativa que não a primária, reconhece-se não simplesmente a linguagem jornalística, mas tem-se também a impressão de uma "notícia de última hora", com os verbos no presente dando o dramatismo e a sensação de perigo que transmite o texto (PQ, p. 130-1):

El mundo del delito se encuentra en "estado de alerta" pues las investigaciones van demostrando que asesinos, estafadores y contrabandistas locales han colaborado en ocultar a los pistoleros porteños y ahora temen las represalias policiales. A última hora circuló la versión de que la banda de Malito se habría dirigido hacia Colonia en un desesperado intento por volver a cruzar el río rumbo a tierra argentina. Hoy (por ayer) fue detenido el contrabandista Omar Blasi Lentini, con su mujer embarazada y sus dos hijos pequeños, por procurar albergue para la banda en la casa del aduanero Pedro Glasser en San Salvador 2108. De inmediato la policía fue tras los rastros del delincuente argentino Hernando Heguilein, "Nando", un ex integrante de la Alianza Libertadora Nacionalista en los tiempos de Perón acusado por Lentini de ser el nexo de todo delincuente de alto vuelo que llegue al Uruguay desde el exterior y que habría servido de enlace entre los prófugos y la delincuencia uruguaya.

Este mecanismo, por um lado, desestabiliza a onisciência do narrador primeiro, já que explicita sua incapacidade de narrar a trama como um todo, de maneira totalmente coerente e 
fidedigna com a suposta realidade que pretende querer retratar. Por outro lado, este mesmo mecanismo oferece uma saída para esta desestabilização, uma maneira de cobrir as lacunas de informações, fazendo com que grandes partes da história cheguem ao leitor através de alguma instância narrativa secundária sobre a qual o narrador primeiro não parece ter um controle absoluto. Além disso, o uso dos jornais na narrativa apresenta outras problemáticas, que estão associadas inexoravelmente à autoridade conferida às fontes jornalísticas nas narrativas do gênero policial e, de maneira mais ampla, nos textos de ficção em geral. Como já comentado no capítulo anterior, desde Edgar Allan Poe e seus três célebres contos considerados por muitos como fundadores do gênero policial - "Os crimes da Rua Morgue", "O mistério de Marie Rogêt" e "A carta roubada" - a imprensa vem ocupando lugar privilegiado como fonte da realidade a ser narrada, o que ocorre de maneiras diversas: tanto o relato jornalístico pode ser tomado como fonte confiável e neutra para o acesso a uma realidade anterior e exterior à narrativa presente, como pode apresentar lacunas e imprecisões incontornáveis ou ser instrumento de manipulações políticas e sociais, conformando e deformando, mais do que informando, a realidade.

Assim, temos também em Plata quemada os jornais como fonte aparentemente neutra e confiável dos fatos narrados - como em "Os crimes da Rua Morgue" -, ainda que o narrador não assuma responsabilidade pelo relato, mesmo no caso de um fato relativamente banal e que não suscita grandes dúvidas ou discussões: “"Al escapar encontraron cerradas las barreras del paso a nivel de la calle Madero y sin parar el auto las cortaron con la ametralladora' (según los diarios)" (PQ, p. 46). Mesmo estes relatos diretos de fatos mais ou menos concretos e que despertam poucas dúvidas, entretanto, podem provocar desconfiança ao se basearem, eles mesmos, em relatos de testemunhas, por exemplo: "Preso de una gran confusión el testigo no llegó a reconocer ninguna cara (dijeron los diarios)” (PQ, p. 36). O problema reside, aqui, em que, apesar da afirmação dos jornais de que a testemunha não reconheceu ninguém, não 
podemos saber se isto é verdade, já que não temos acesso ao íntimo deste personagem - o que seria possível para um narrador onisciente. Em outro trecho, um comerciante diz ter estado no apartamento da rua Julio Herrera y Obes, “conociendo así el 'departamento más fastuoso que haya visto', según expresó a los periodistas.” (PQ, p. 90). Como tal descrição contradiz com outras apresentadas no romance, como a do próprio narrador primeiro, o veiculado na imprensa é posto em xeque: a pessoa entrevistada teria realmente estado no apartamento? Sua descrição do local, que é, no mínimo, exagerada, busca condizer, talvez, com o que a imprensa e os leitores esperam saber de antemão dos bandidos, envoltos em uma aura quase mitológica? O que é possível, enfim, reter das notícias de jornais mencionadas na narrativa como forma de dar-lhe um sentido mais coeso? É isto, por outro lado, que se deve buscar na leitura do romance?

Passa-se então à constatação de que a informação de fonte jornalística deve ser relativizada por incompleta, insegura ou ambígua - tal como ocorre em "O mistério de Marie Rogêt”. Em uma das primeiras vezes em que o procedimento de recorrer à narrativa dos jornais aparece, lemos: "La confusión indescriptible que el alevoso ataque produjo no permitió, en los primeros momentos, precisar lo que había ocurrido (decían los diarios)" (PQ, p. 41). Ou seja, os jornais informavam que não havia nada de certo a ser informado e o narrador primeiro, que não pode - ou simula não poder - precisar os detalhes do assalto, vê sua "fonte auxiliar" da narrativa mostrar-se não só como inútil, mas também como um elemento a mais a reforçar a ambiguidade e os não-ditos da narrativa geral do romance.

Por fim - como em "A carta roubada", onde se procura resguardar o fato da exposição na imprensa e da manipulação política - explicita-se em Plata quemada a manipulação dos fatos por meio da imprensa: "Las informaciones en los diarios circulaban entre líneas y había muchas operaciones de contrainteligencia en medio de las noticias" (PQ, p. 54). Se o próprio narrador primeiro do romance põe em cheque a autoridade da narrativa jornalística, tudo nela 
passa a ser passível de suspeição e contestação. Assim, declarações de autoridades - “'Los que cruzaron (ha dicho off the record el comisario Silva) son sujetos peligrosos, antisociales, homosexuales, y drogadictos' [...]" (PQ, p. 91, grifo meu) - se convertem em somente uma versão a mais sobre os fatos nos quais supostamente estaria baseada a narrativa. Por outro lado, a própria imprensa, conforme avança a narrativa do romance, vai assumindo um discurso cada vez menos "objetivo" sobre a realidade dos fatos, ora apelando para o sensacionalismo que atende a fins mercadológicos - vender o jornal encharcado do sangue do qual o povo está sedento -, ora tentando simplesmente construir essa realidade por meio de um discurso a partir de posições ideológicas prévias:

Una verdadera orgía de sangre (según los diarios) comenzó así en el Uruguay el miércoles 4 de noviembre de 1965 [...] (PQ, p. 121)

[...] la noticia había rebotado en la tele, como una prueba (según los periodistas) de que los delincuentes estaban dispuestos a jugar con la vida de todos los implicados en esta complicada operación de rescate. (PQ, p. 161)

Más que dos jóvenes que se habían marchado de esta vida parecía que (según el cronista de El Mundo), lanzados por una mezcladora de cemento, no hubiera más que trozos de huesos, pedazos de intestinos y de tejidos colgantes a los que era imposible suponer que habían estado dotados de vida. (PQ, p. 165-6)

Y también la idea de que la plata quemada era un ejemplo de locura asesina. [...] Ese acto (según los diarios) era peor que los crímenes que habían cometido, porque era un acto nihilista y un ejemplo de terrorismo puro. (PQ, p. 192)

Inmediatamente después de ese acto que paralizó a todos, la policía pareció reaccionar y comenzó una ofensiva brutal como si el tiempo en que los nihilistas (como eran ahora llamados por los diarios) terminaban su acto ciego los hubiera predispuesto y enceguecido y los hubiera preparado para la represión definitiva. (PQ, p. 193)

Este recrudescimento das posições ideológicas por meio dos discursos da mídia é reforçado, particularmente depois do cerco ao apartamento, pelo acréscimo do rádio e da 
televisão às narrativas jornalísticas. Se o rádio chega a dar voz a quem parece condenar a execução sumária dos criminosos por parte da polícia - "Mi hija y yo - según la señora Vélez (a radio Carve) - pasamos todo el tiempo en el fondo de la cocina [...] Los cazan como a ratas... Me dieron lástima, no se mata así a un cristiano...” (PQ, p. 209) -, a televisão só reforça um suposto sentimento popular - sentido?, criado?, incutido? - que condena os criminosos, sem maiores reflexões, baseado essencialmente no escândalo da queima do dinheiro (grifos meus):

Las cámaras hacían sus paneos sobre los heridos porque por primera vez en la historia era posible transmitir en vivo, sin censura, los visajes de los muertos en la batalla de la ley contra el crimen. (PQ, p. 166)

[...] estos cretinos, dijo una señora, pero son malvados, tienen mala entraña, son unos bestias, dijeron los testigos y la televisión filmó y luego trasmitió durante todo el día la repetición de ese ritual, al que el periodista de la TV Jorge Foister, llamó acto de canibalismo.

- Quemar dinero inocente es un acto de canibalismo. (PQ, p. 191)

[...] quedó una pila de ceniza, una pila funeraria de los valores de la sociedad (declaró en la televisión uno de los testigos) [...] (PQ, p. 193)

Curiosamente, o sensacionalismo e as manipulações da imprensa são percebidos pelos próprios criminosos, protagonistas da trama. Se, como já havia apontado Michelle Clayton (PÉRSICO, 2004, 139), Malito lê avidamente as páginas policiais, ao mesmo tempo em que se incomoda com seu sensacionalismo - "De la misma forma repulsiva y abyecta de siempre (según Malito), los diarios informaban [...]” (PQ, p. 56) -, Dorda acaba, a seu modo, se identificando com o discurso sensacionalista, sem nenhuma reflexão sobre a ideologia por trás dele: "Le entusiasmaban esas palabras y veía como en una foto [...] su cuerpo muerto en la tapa de Crónica. 'Cayó la hiena Dorda.”” (PQ, p. 220). Quando se analise a narrativa que produz o Gaucho Dorda dentro do romance, portanto, será interessante voltar a ver como o 
personagem vê e constrói o seu ser e o seu atuar a partir de discursos que lhe são alheios e não necessariamente produzidos por suas próprias experiências e reflexões.

Dentro do conjunto de discursos jornalísticos, Emilio Renzi, como aponta Julio Premat, constitui uma das instâncias narrativas fundamentais do romance, mas se este jornalista - e "El Mundo", o jornal em que este trabalha - narra, também o fazem outros jornais. Enquanto produtor de discurso da imprensa, Renzi se assemelha em alguns pontos com outros discursos da imprensa presentes no texto: cede, às vezes, ao sensacionalismo ${ }^{52} \mathrm{e}$ tampouco sua narrativa jornalística parece dar conta, ao fim, dos fatos de maneira completa e transparente. Há, de qualquer forma, o que distingue o discurso do jovem cronista de "El Mundo" dos outros discursos da imprensa presentes no romance.

Apesar de só aparecer na trama a partir da página 84 e de seu discurso só passar a constituir uma parte da narrativa na segunda metade do livro (a partir da página 133), Renzi distingue-se de vários modos. É um dos poucos jornalistas nomeados no romance e o único que tem uma descrição mais aprofundada - os outros discursos da imprensa no romance, na verdade, caracterizam-se mais por serem discursos dos jornais, das rádios e das TVs, e não dos jornalistas. A singularidade de Renzi, a partir daí, vai se aprofundando. Explicitam-se, por exemplo, seu idealismo quase ingênuo no desempenho de seu ofício - “[...] si hago preguntas es porque quiero escribir una crónica veraz de lo que está pasando.” (PQ, p. 199) - e também os pendores literários do jornalista:

'Hybris', buscó en el diccionario el chico que hacía policiales en El Mundo: la arrogancia de quien desafía a los dioses y busca su propia ruina' (PQ, p. 91)

De todos modos el destino había empezado a armar su trama, a tejer su intriga, a anudar en un punto (y esto lo escribió el chico que hacía policiales

\footnotetext{
52 "Más que dos jóvenes que se habían marchado de esta vida parecía que (según el cronista de El Mundo), lanzados por una mezcladora de cemento, no hubiera más que trozos de huesos, pedazos de intestinos y de tejidos colgantes a los que era imposible suponer que habían estado dotados de vida.” (PQ, p. 165-6)
} 
en El Mundo) los hilos sueltos de aquello que los antiguos griegos han llamado el muthos. (PQ, p. 106)

Un Cristo, anotó el chico de El Mundo, el chivo expiatorio, el idiota que sufre el dolor de todos. (PQ, p. 240)

Desta forma, o discurso de Renzi ganha espaço (no capítulo Cinco, começa na página 133 e prossegue por oito páginas até o fim do capítulo) e converte-se, de fato, numa das principais vozes narradoras do romance. A relação deste discurso com o do Epílogo e com a figura de autor de Piglia, entretanto parece mais fundamental, como se verá mais adiante.

\section{Narram os personagens}

Do mesmo modo que os jornais, muitos personagens aportam suas versões da historia, a começar pelas testemunhas anônimas, tanto na Argentina ${ }^{53}$ como no Uruguai ${ }^{54}$. Estas versões que aparecem filtradas tanto pelo narrador primeiro como pelos meios de imprensa, além de contribuir para a fragmentação da narrativa, dão força à ambiguidade desta ao se mostrarem muitas vezes contraditórias, ilógicas ou aparentemente desnecessárias. Como estratégia narrativa do romance como um todo, entretanto, cumprem, sem dúvida, seu papel de problematizar a representação do real e de colocá-la como diretamente subordinada aos discursos sociais que permeiam a trama.

Na mesma linha de composição do romance pelo acúmulo de vozes díspares - o que coaduna com a visão de Bakhtin do romance como gênero que apresenta uma estratificação interna que o conduz ao pluriestilístico, plurilíngue e plurivocal (2002, p. 72-84) - aparecem os discursos de personagens tangenciais da trama que também se constituem como instâncias

\footnotetext{
${ }^{53}$ Por exemplo: "Algunos testigos aseguran haber visto a Malito en el hotel con una mujer." (PQ, p. 15). Também nas páginas 16,35 e 43.

54 "La cara del comisario quedó borrada por la descarga como se le hubieran abierto la carne desde la boca hacia afuera quedando sólo un hueco sanguinolento (así dijo un testigo)." (PQ, p. 188) Há vários outros casos como, por exemplo, nas páginas 90 e 191.
} 
narrativas. Se, para Michelle Clayton, Malito escreve parte da intriga por ser o chefe do bando, o que pensa, organiza e arma o assalto, tampouco é exagero dizer que todos esses personagens secundários conformam também narrativas, seja por seus atos, seja por seus discursos.

Hernando Heguilein - o militante peronista que apresenta o golpe a Malito - aporta a dimensão política à história, por exemplo, quando é preso: “'Soy un hombre de principios, un preso político [...] y lucho por la vuelta del general Perón', declaró el delincuente.” (PQ, p. $132)^{55}$. Fontán Reyes - o cantor de tango e informante do bando - revela as ligações da quadrilha com figuras importantes da política local argentina: seu tio era vereador em San Fernando e foi o primeiro a idealizar o roubo ao caminhão-forte ${ }^{56}$. Blanca Galeano - a amante do Cuervo - ilustra os métodos de interrogatório com tortura da polícia argentina ao mesmo tempo em que, por uma paixão idealizada, pouco revela ou dá informações duvidosas sobre a fuga do bando ao Uruguai. Yamandú Raymond Acevedo - o uruguaio que ajuda os argentinos em Montevidéu - é mais pragmático ao pintar um quadro de selvageria dos criminosos argentinos, ao passo em que busca diminuir sua culpa em toda a série de acontecimentos ${ }^{57}$.

Por fim, Giselle - a garota uruguaia com quem se envolve Nene - e Lucía Passero - a senhora que os delata à polícia em Montevidéu -, escrevem especialmente a parte trágica da intriga com seus atos, "explicados" por elas mesmas. Lucía, personagem clave no desenrolar dos acontecimentos que culminariam no cerco ao apartamento da rua Julio Herrera y Obes, ao mesmo tempo em que constrói a trama com seus atos, justifica-os por seus pensamentos, filtrados pelo narrador primeiro: "Volvió a experimentar lo que ella misma llamaba la

\footnotetext{
${ }^{55}$ Antes já pensava: "Nando tenía la ilusión de hacerlos entrar en la Organización. Poner caños, robar bancos, cortar líneas eléctricas, provocar incendios, disturbios." (PQ, p. 64)

56 "Carlos A. Nocito [...] era un influyente, un hombre que hacía favores en la zona, un típico puntero que bordeaba las actividades delictivas. En otro lugar habría sido un hombre de la mafia pero aquí se dedicaba a pequeños negocios en los que entraba la coima y la protección a quinieleros y quilombos clandestinos." (PQ, p. 87-8)

57 “Eran unos reventados, dijo Yamandú, eran tipos que vivían en una delirata total, querían llegar a Nueva York [...], deliraban con trabajar para la mafia puertorriqueña [...]. Nunca, dijo Yamandú, vi tipos iguales a esos. Exageraba, Yamandú, seguramente, para lograr aflojar la presión que tenía encima...” (PQ, p. 126-7)
} 
tentación del mal, un impulso que a veces le daba por hacer daño o ver a alguien que le hacía daño a otro y contra esa tentación luchaba desde chica.” (PQ, p. 121). Já Giselle, pseudônimo de Margarita Taibo, representa por si um personagem ambíguo e muitas vezes inacessível ao narrador primeiro, aos jornalistas ou aos outros personagens (a polícia e os bandidos). Detida e interrogada, não sabemos, por suas declarações, qual teria sido de fato sua participação no desfecho trágico da história: teria ela conduzido o bando propositalmente ao apartamentoarmadilha? Teria denunciado os argentinos à polícia posteriormente? Suas versões da história, sem nenhuma outra corroboração na narrativa, são confiáveis?

Já entre os personagens principais do romance, se Premat vê o Gaucho Dorda como um dos que refletem a produção do texto, pode-se acrescentar alguns comentários. Em primeiro lugar, é preciso notar que Dorda atua de maneira muito semelhante à de seus colegas de bando e fala muito pouco. Seu canal de expressão é, essencialmente, Nene (PQ, p. 68-9):

Ellos, del otro lado, cocinaban todo. No hablaban con él, nunca le preguntaban nada. De los planes, se ocupaba el Nene. Porque el Gaucho y el Nene, eran, para el Gaucho, uno solo. [...] La plata y las decisiones significaban poco para él. Su interés exclusivo eran las drogas [...]

Além disso, sem desfazer-se do conceito de que o Gaucho propriamente conforma a narrativa do romance e a reflete, é necessário agregar a voz do Dr. Bunge, o psiquiatra que o trata. Do que narra Dorda - ou do que narram as vozes em sua cabeça - podemos separar dois tipos de narrativa: a que nos chega por intermédio do narrador primeiro e a que nos chega através dos relatórios psiquiátricos do Dr. Bunge. Esta é a narrativa de um personagem que define o Gaucho como "un lunático criminal que actúa con una sonrisa nerviosa, angelical y sin alma" (PQ, p. 72) e que anota em sua ficha: "obseso sexual, perverso polimorfo, libido desmedida. Peligroso, psicótico, invertido. Mal de Parkinson” (PQ, p. 78). Por isso é preciso considerar que há pelo menos duas histórias que nos narra o Gaucho Dorda: a que vem diretamente de sua cabeça - ainda que mediada pelo narrador primeiro - e a que vem dos 
relatórios do Dr. Bunge - ainda que também mediada, no fim das contas, pelo narrador primeiro. As instâncias narrativas que surgem dos relatórios do Dr. Bunge, por sua vez, se desdobram através dos relatos de terceiros trazidos por seu paciente (a mãe; o sacristão da igreja na cidade natal; Rusita, a prostituta que assassinou quando mais jovem). A narrativa que conforma Dorda, então, é um caldo de outras narrativas sobre ele. Sua confusão mental só encontra alguma forma de expressão através da proteção de Brignone e sua vida parece constituir-se somente dos relatos sociais estereotipados (da imprensa, como vimos anteriormente; da família; da igreja; da psiquiatria; da sociedade "de bem”) que ele acaba por aceitar, aparentemente, por sua fragilidade intrínseca.

Dentro do gênero policial, então, essa voz intermediada do Gaucho Dorda é, de certo modo, sui generis. Nas narrativas mais tradicionais do gênero há, na verdade, uma boa variedade de tipos de narradores: o onisciente em terceira pessoa, o narrador-testemunha (muitas vezes, o amigo e/ou ajudante do detetive), o detetive que narra em primeira pessoa e até mesmo o criminoso. Este, entretanto, como em The killer inside me ( $O$ assassino em mim), de Jim Thompson, narra geralmente também em primeira pessoa e assume sua própria voz dentro da narrativa, diferentemente do caso de Dorda. Em suma, ainda que o gênero apresente certa variedade de pontos de vista narrativos, é no mínimo incomum que a voz do "bandido" nas histórias policiais esteja presente ou, quando está, que apareça mediada por terceiros. A apresentação do ponto de vista dos criminosos e da visão que outros personagens têm dele passa a ser, então, um traço de transgressão ao gênero em Plata quemada.

Não obstante, não é só ao Gaucho a quem o narrador cede a voz entre os personagens principais. Especialmente no quarto capítulo (PQ, p. 93-7), também o Nene Brignone narra sua própria história e sua visão dos fatos. Além disso, em suas conversas com Giselle antes do cerco, Nene conta diversas histórias, supostamente falsas, a sua amante. Entretanto, a dúvida que surge no leitor, a partir da lógica narrativa que propõe o romance, é de onde surgem essas 
histórias. Se atribuímos a narrativa das conversas ao narrador primeiro e confiamos em sua onisciência - o que, como foi visto, é no mínimo complicado -, concluímos que muito do que o Nene diz é mentira. Se pensamos, por outro lado, que as conversas narradas no romance se originam de testemunhos de um personagem, Giselle, tal convicção se esvai, afinal não se sabe a honestidade desses testemunhos ou os reais interesses de quem os deu $^{58}$. No fim, boa parte da narrativa de Nene tanto pode ser dele de fato como de Giselle, ainda que esta a atribua a Nene.

Por fim, há a narração da polícia, desde relatórios policiais mais vagos e sem autoria indicada até, muito mais importante, os relatórios, declarações e até pensamentos (filtrados pelo narrador primeiro) do comissário Silva. Chefe de Polícia da Zona Norte da Grande Buenos Aires, o comissário Cayetano Silva é o policial argentino que inicia as investigações do roubo em San Fernando e vai, depois, até Montevidéu em busca - o à caça - dos criminosos. Através dos relatórios da polícia, de suas declarações à imprensa e especialmente de suas ações se arma a cena final do romance: o cerco, os movimentos da policia, as atitudes dos criminosos, a reação do público. A narrativa mais uma vez não se constrói só por relatos, mas pela ação dos personagens e, no caso de Silva, não só é significativo o que ele diz e faz como o que deixa de dizer e fazer. Em sua figura encarna-se, por exemplo, a narrativa do estado dirigida à população, cheia de enganos, manipulações e imposições. Para ele, um falso discurso encobre a realidade das coisas (PQ, p. 86):

Hay crímenes, adulterios, robos, pero uno anda por las calles y todo se mueve normalmente y con el aire de falsa tranquilidad que los mismos transeúntes le dan a las cosas. [...] Todos tratan de ocultar el mal. Pero la maldad acechaba en las esquinas y adentro de las casas.

\footnotetext{
${ }^{58}$ São exemplos destas falas atribuídas ao Nene por Giselle: "(sería mejor decir, había dicho [él], contó la chica)"; "(le dijo a la chica, según declaró ella)"; "(contó el Nene, declaró luego la muchacha)"; (PQ, p. 104; $105 ; 108)$
} 
Como Silva se crê um conhecedor da verdade oculta e, ao mesmo tempo, responsável por um discurso confortador e mantenedor do status quo social, não surpreende que declare a princípio que descarta "la posibilidad de que haya habido alguna colaboración interna del personal de la Municipalidad" (PQ, p. 58) e, depois saibamos, através do narrador, que o comissário praticava usualmente a tortura e "tenía el respaldo de Coordinación porque su hipótesis era que todos los crímenes tenían un signo político.” (PQ, p. 66) Sua narrativa apresenta contradições como se estas formassem parte de uma lógica de discurso à qual não cabe a população entender ou questionar: "Sus declaraciones eran sentenciosas y contradictorias (y aun incomprensibles), como cuadra al razonamiento policial.” (PQ, p. 83). Outros discursos, outras versões da história, devem ser vedados, como quando Emilio Renzi lhe diz que quer escrever uma "crônica veraz” dos fatos e Silva lhe responde: “Una crónica? ¿Veraz? No creo que tengas bolas.” (PQ, p. 199). A narrativa do comissário, se para o leitor se mescla e até se confunde com todas as outras, para o policial é peremptória e o discurso oficial é o que todos deveriam tomar como a realidade (PQ, p. 91):

Los que cruzaron (ha dicho off the record el comisario Silva) son sujetos peligrosos, antisociales, homosexuales, y drogadictos', y agregó el jefe de la policía "no son tacuaras ni peronistas de la resistencia, son delincuentes comunes, psicópatas y asesinos con frondosos prontuarios'.

O discurso que tenta impor Silva ilustra, assim, o que Piglia aborda no ensaio "Tres propuestas para el próximo milenio (y cinco dificultades)": "Podríamos decir que también el Estado narra, que también el estado construye ficciones, que también el Estado manipula ciertas historias.” (2001b, p. 222) As próprias conversas entre Silva e Renzi remetem às que se dão entre o jornalista e o ex-oficial de inteligência no conto "Esa mujer", de Rodolfo Walsh (2001), discutido por Piglia no ensaio, já que em ambos os casos temos a voz do estado confrontada pela do intelectual que tenta aceder a algo da esfera do popular que aquele tenta 
ocultar - o corpo de Evita, no caso de "Esa mujer"; a versão dos criminosos, no caso de Plata quemada.

\section{Narra Piglia?}

Toda a quase exaustiva cadeia de instâncias narrativas que se entrelaçam e que foi vista até o momento é sucedida por uma instância mais, com a qual todas aquelas se relacionam. O Epílogo, em que surgiria "Ricardo Piglia”, "el escritor en la escena ficcional”, como o define Premat (2009, p. 211), parece não somente produzir outro desdobramento, ou seja, criar outro texto em que se narra a produção de tudo o que foi narrado anteriormente, como também dar conta da multiplicidade de narrativas e narradores que constroem a intriga, justificando-os. O "tramposo pacto realista", como muito bem define Premat, parece querer tranquilizar o leitor depois de tantas vozes dispersas (PQ, p. 245-6):

No siempre los diálogos o las opiniones transcriptas se corresponden con exactitud al lugar donde se enuncian pero siempre he reconstruido con materiales verdaderos los dichos y las acciones de los personajes. [...] El conjunto del material documental ha sido usado según las exigencias de la trama, es decir que cuando no he podido comprobar los hechos en fuentes directas he preferido omitir los acontecimientos.

Curiosamente, no mesmo epílogo, parte importante do "material verdadeiro", do "material documental" usado na confecção do romance é atribuída ao correspondente do jornal argentino El Mundo em Montevidéu que assinava seus textos como "E.R." e que corresponde no romance ao jovem jornalista... Emilio Renzi. O romance, assim, se fragmenta e se constrói a partir das pistas, dos indícios, dos entreditos, das falhas que a própria realidade criada por Piglia apresenta. O seu alter ego irônico, que vive "literariamente", na própria literatura não dá conta de sua realidade, como não dão conta da realidade dos fatos os outros 
jornalistas e meios de imprensa que cobrem o roubo e a fuga dos criminosos, nem os personagens que participam da história.

Como os eventos romanceados em Plata quemada se baseiam em um episódio da crônica policial argentina e uruguaia, cria-se um paradoxo: a "realidade dos fatos" não pode ser reconstituída plenamente, ao passo que a ficcionalização tampouco se presta a amenizar as lacunas que percebemos na apreensão dessa mesma realidade ${ }^{59}$. Assim, o leitor não tem na leitura do romance um acesso à história real - o texto não a reconstrói através da pesquisa histórica -, nem a uma ficção que poderia imaginar algo próximo dessa realidade - o texto não a constrói a partir da liberdade literária ${ }^{60}$.

O "pacto realista trapaceiro", de que fala Premat se constitui, então, na aceitação da literatura ficcional de Plata quemada como verdade empírica dos fatos, sugerida maliciosamente na própria narrativa, como na primeira frase do Epílogo: "Esta es una historia real.” (PQ, p. 245). O truque é reforçado pelas declarações de exatidão do narrador do Epílogo, bem como pela enumeração das fontes que supostamente teria utilizado. Por fim, há o estilo jornalístico usado em boa parte do romance e o fato das informações do Epílogo - as fontes, a história do surgimento do texto e seu desenvolvimento ao longo de anos aparecerem justamente aí, como epílogo ${ }^{61}$, e não no primeiro capítulo, ou em um prefácio, por exemplo. Terminada a trama principal, com o fim do cerco e captura e morte dos bandidos, pode-se simular uma voz externa ao romance - "el escritor en la escena ficcional", como bem

\footnotetext{
${ }^{59}$ A própria crônica policial da época do episódio e estudos posteriores são bastante confusos e deixam várias interrogações sobre o que de fato teria acontecido entre o roubo em San Fernando, o cerco em Montevidéu e a morte dos criminosos. A esse respeito, veja-se COBAS (2000), HABERKORN (1998) e a série de reportagens do escritor e jornalista Julio Cesar Martínez (JUMA, 2004a, 2004b, e 2004c) sobre o caso Liberaij - o edifício em Montevidéu onde se deu o cerco aos bandidos argentinos.

${ }^{60} \mathrm{O}$ mesmo problema de representação Piglia já discutia, no início e no fim de "La prolijidad de lo real" - conto depois adaptado como o início de Respiración artificial: "¿Hay una historia? [...] ¿Cómo narrar los hechos reales?" (1978, p. 26-8)

${ }^{61}$ Para Aristóteles, na Arte retórica, "na peroração [epílogo] é mister recapitular as provas que serviram para a demonstração. O início da peroração consistirá em declarar que cumprimos o que havíamos prometido" e "Para terminar, o assíndeton fica bem aqui, para que tenhamos uma peroração e não um novo discurso: 'Tendo dito, ouvistes, estais a par da questão, julgai.”([s/d], Capítulo XIX, p. 269)
} 
o define Premat - e sugerir o que vem antes como pertencente ao gênero jornalístico ou à nãoficção.

Que se escrevam obras de não-ficção - na linha de A sangue frio, de Truman Capote, ou Operação massacre, de Rodolfo Walsh - não constitui, obviamente, um truque ou uma trapaça do narrador. Do mesmo modo, uma ficção forjada a partir do submundo social criminosos, drogaditos, prostitutas - pode ser encontrada na própria literatura argentina em Roberto Arlt, por exemplo. Em Plata quemada, no entanto, o procedimento parece ser o de jogar com os gêneros da não-ficção e da ficção - remetendo à literatura de Arlt, assim como à narrativa policial ou à tragédia - dentro de uma obra que não respeita, e, por isso, não se enquadra em, nenhum gênero preestabelecido.

Enquanto o Epílogo, em sua forma, principalmente, conforma o truque ou o jogo, ao mesmo tempo, desestabiliza o próprio jogo. Se são arroladas as diversas fontes da reconstituição da história ${ }^{62}$, também se põe em dúvida sua autoridade: não só Emilio Renzi é um personagem evidentemente ficcional, como também parecem sê-lo Margarita Taibo (Giselle) - cujo testemunho foi supostamente consultado -, Roque Perez - que teria dado uma entrevista depois do caso - ou o Doutor Bunge - cujos relatórios também teriam servido de fonte. O fato de personagens fictícios servirem de fonte para uma suposta reconstituição de

${ }^{62}$ Foram fontes consultadas, segundo o narrador: (PQ, p. 247-9)

- Entrevista de Dorda en el hospital al enviado de El Mundo, publicada en 14 y 15 de marzo de 1966;

- Transcripción de los interrogatorios a Dorda en los archivos del caso;

- Los informes psiquiátricos del Dr. Amadeo Bunge;

- Declaraciones testimoniales y legajos del caso (con la ayuda del Dr. Nelson Sassia, fiscal del juzgado 12 de Montevideo) - testimonios de Margarita Taibo, Nando Heguilein, Yamandú Raymond Acevedo y otros;

- Actas de los interrogatorios a Blanca Galeano, Fontán Reyes, Carlos Nino y otros (con la ayuda del abogado Raúl Anaya);

- Descargo y declaración del comisario Cayetano Silva en el sumario interno a que fue sometido por la policía por cohecho (fue sobreseído);

- Transcripción de las grabaciones secretas de la policía en el apartamento;

- Entrevista de Carlos M. Gutiérrez a Roque Pérez, publicada en Marcha, en noviembre de 1965;

- Archivo de diarios de Bs. As., especialmente Crónica, Clarín, La Nación y La Razón - "Fueron de especial utilidad las crónicas y las notas de quien firmaba E.R., que cubrió el asalto y fue enviado especial del diario argentino El Mundo al lugar de los hechos.";

- Archivo de diarios de Montevideo, especialmente El Día, Acción, El País y Debate;

- El escultor Carlos Boccardo, quien vivía en Montevideo en la época, por "una serie de precisiones y de materiales que me ayudaron a redactar las distintas versiones de la historia." 
fatos reais e históricos poderia servir - e até seria de se esperar que o fizessem - para suprir as lacunas de informação deixadas pela pesquisa factual, mas não é isso que acontece. Cada suposta fonte - jornais, personagens reais e fictícios, documentos mencionados no epílogo só faz trazer à narrativa mais ambiguidade ${ }^{63}$.

Deduz-se, então, que em Plata quemada a literatura não está a serviço da história nem vice-versa: não lemos um livro reportagem nem um romance histórico. Não parece interessar a Piglia, como tampouco em seus outros romances, como a realidade se converte em discurso literário, mas sim como os discursos sociais, através da literatura, conformam realidades, literárias ou não. Este mecanismo parece se refletir dentro do próprio romance: “[...] porque la policía y los malandras (pensaba Renzi) son los únicos que saben hacer de las palabras objetos vivos [...] La conversación se fue extendiendo, como si fuera otra parte del combate." (PQ, p. 186) O poder da palavra brota dos discursos da autoridade social e política, bem como dos elementos marginais da mesma sociedade. Não é o escritor, para o narrador, quem "faz das palavras objetos vivos", mesmo que se evidencie o caráter autorreferencial e metalinguístico do fragmento, pois, afinal, estamos lendo literatura.

Se parte de Plata quemada se constitui, justamente, na pluralidade de vozes que tentam dar conta da narrativa, os narradores múltiplos e conflitantes não são os únicos discursos que se entreveem no romance. As muitas citações do texto, por exemplo, agregam discursos que também constituem narrativa, como se verá a seguir.

\subsection{As citações como narrativa}

Muito já se disse sobre as citações, referências e traduções na obra de Ricardo Piglia. O próprio escritor, inclusive, diz, sobre suas leituras da infância, que “[...] ahí está por

${ }^{63}$ É curioso, por exemplo, que o escultor Carlos Boccardo, um personagem real, receba os agradecimentos do autor por "una serie de precisiones y de materiales que me ayudaron a redactar las distintas versiones de la historia." Isto tendo-se em conta que o que mais abunda no romance sejam imprecisões! 
supuesto condensada toda la erudición delirante y las mezclas más extravagantes que me gustan en Arlt y en Borges y por supuesto también en lo que yo hago, o al menos en lo que me gustaría hacer.” (PIGLIA, 2001a, p. 117)

De todo modo, Plata quemada - a despeito de suas diversas instâncias narrativas parece a um primeiro exame escapar a essa lógica da escritura nascida de múltiplas fontes e que configura um texto na fronteira de diversos gêneros, essa "mezcla extravagante" que está muito mais evidente em Respiración artificial ou mesmo em La ciudad ausente. Adriana Rodríguez Pérsico diz, por exemplo, que a leitura de Plata quemada não está destinada a um "lector sabueso, capaz de desovillar la madeja de intertextos, citas, personajes literarios o históricos que circulan por los relatos [de Piglia]" (2004, p. 113), mas sim que se volta a outra parte da produção do autor no qual o anedótico e a oralidade são características mais distintivas.

No entanto, debaixo de sua capa de romance noir, de relato criminal, de sua trama essencialmente linear, há um cruzamento intenso de citações - termo que a partir daqui tomarei em um sentido bastante amplo, abarcando referências a personagens históricos e literários, aos escritores a quem Piglia sempre rende homenagens, a situações e à práxis narrativa desses mesmos escritores, etc. Julio Premat, primeiro em um artigo em Ricardo Piglia: una poética sin límites, compilado por Rodríguez Pérsico (2004, p. 127), depois em seu Héroes sin atributos (2009, p. 210), relaciona diversas dessas citações a Arlt, a Borges, a Kafka, ao Martín Fierro e a La cautiva, inclusive à obra do próprio Piglia. Gisle Selnes nota a semelhança entre o jovem Emilio Renzi de Plata quemada e o também jovem jornalista do Yidische Zaitung, em "La muerte y la brújula" de Borges, ambos com suas petulantes ironias frente às autoridades policiais ${ }^{64}$ (SELNES, 2006). É possível, além disso, relacionar a relação entre o jornalista Renzi e o comissário Silva com a que há entre os personagens de "Esa

\footnotetext{
${ }^{64}$ Outro jornalista/investigador petulante e desafiador que vem à mente é o Rouletabille, de Gaston Leroux, no romance policial O mistério do quarto amarelo, de 1907, clássico do "enigma de quarto fechado" (2004).
} 
mujer", de Walsh, como já foi apontado. A lista das citações recompiladas por diversos críticos e estudiosos da obra de Piglia seria imensa e não vale a pena aqui mencioná-las todas. De todo modo, é importante apontar como as citações não são simplesmente curiosidades ou ostentação erudita por parte de Piglia, mas sim elemento fundamental da construção do texto, de uma práxis narrativa que marca toda sua obra.

\section{A literatura narra}

Entre as diversas citações presentes em Plata quemada, muitas relacionam o romance à literatura em geral e vão de Plutarco a Gautier, passando por Kafka, Dante e Brecht. Ao mesmo tempo sutis e evidentes, estas referências podem ser tomadas, mais do que como citações aleatórias ou com um mero fim de homenagem, como elementos constitutivos de uma leitura mais ampla do texto.

Assim, quando o Nene e Giselle ouvem o compacto da fictícia banda Heart and Body com as músicas "Parallel lives" (no lado A) e "Brave captain" (no lado B), é possível ler na cena uma microrreprodução do romance, como aponta Selnes (2006): de um lado "a cabeça e o corpo" - Malito e os outros meliantes - e de outro o "bravo capitão" - o comissário Silva. As "vidas paralelas" contrapõem a igual violência que permeia os dois lados da lei, bandidos e polícia. Ainda notada por Selnes está parte da letra de uma das músicas reproduzida no romance e que parece prenunciar o incêndio no apartamento ao final da história: "And if I can find a book of matches // I' goin' to burn this hotel down" (PQ, p. 111) ${ }^{65}$. O que o crítico deixa de apontar, entretanto, é à referência às "Vidas paralelas" de Plutarco, que também poderiam se relacionar ao romance: como o biógrafo, ensaísta e filósofo romano compara as vidas de ilustres gregos e romanos a partir da realidade diferente em que viveram, a citação

\footnotetext{
${ }^{65} \mathrm{Na}$ verdade, outra citação, literal desta vez, à canção "Mr. Siegel", de Tom Waits, sobre o mafioso novaiorquino Bugsy Siegel, um dos principais impulsores da indústria do jogo que transformou a até então pequena cidade de Las Vegas na imensa Meca dos cassinos que é hoje.
} 
em Plata quemada pode remeter a uma leitura do conflito entre lei e subversão, polícia e marginalidade, que não supõe antagonismo em primeiro lugar, mas paralelismo. O romance oferece, então, um retrato do atrito entre as duas caras da mesma sociedade, e não desta com algo que lhe seria alheio - o banditismo.

A extrapolação de uma pequena citação no texto a uma referência sobre a escrita e um modo de ler o romance como um todo pode ser levada, do mesmo modo, a vários outros casos. O "nome de guerra" - como o "nombre falso" sempre presente na obra de Piglia - de Margarita Taibo, Giselle, remete ao libreto de Téophile Gautier para o famoso balé homônimo. Entretanto, a garota uruguaia que poderia representar um alívio ou mesmo uma salvação para o Nene Brignone acaba se revelando só uma quimera idealizada, mas no fundo falsa. O romantismo cede lugar a uma realidade dura, onde surge até a suspeita de traição por parte da mulher - aqui Giselle não mais protege -, o que remete à morte de modelos idealizados do passado, como se verá também na figura do gaucho.

As referências a Dante e a situações dantescas ${ }^{66}$ remetem a um universo de danação religiosa ao mesmo tempo em que reforçam um destino inescapável aos personagens, o que os inserirá também no plano da tragédia. Kafka, que é "homenageado" pelo comerciante grego “K”, suposto dono do apartamento onde se desenrola o cerco em Montevidéu, também é uma citação passível de expansão. Em Plata quemada, o apartamento, cujos(s) dono(s) e cujas relações com a polícia nunca ficam completamente esclarecidos, é o reverso do castelo no romance de Kafka. Se neste, K está aleijado do centro do poder de autoridades misteriosas e inacessíveis, naquele pode ser um dos donos do espaço em que o poder da ordem estabelecida aprisiona os marginalizados dela. A citação reforça o texto como discurso sobre a opressão social correlacionando Kafka e o apartamento/ratoeira.

\footnotetext{
66 "Eran gritos de las ánimas perdidas en las angustias del Infierno de Dante [...]"; "Cuando el cronista destacado en el escenario de la batalla entró en el departamento el espectáculo era realmente dantesco." (PQ, p. $180 ; 240$, grifos meus).
} 
Em plano um pouco diferente estão as citações a Brecht na epígrafe e no Epílogo. Explícitas, estas buscam, de certo modo, condicionar a leitura do texto. Em outras palavras, o próprio autor oferece uma clave de interpretação brechtiana ao romance, o que deve ser visto com cuidado, já que, como foi visto, todo o Epílogo parece insidioso. Assim, o "gesto metafórico" de Brecht mencionado no romance ${ }^{67}$ não deve ser tomado como parâmetro único de análise do texto, ainda que sua leitura como relato social que tem como tema a violência ilegal seja inescapável.

Por fim, têm especial relevância as citações à literatura argentina - com seus escritores, temas, personagens, etc -, da qual Plata quemada faz parte e com a qual se relaciona de maneira bastante intensa. As citações a Arlt, por exemplo, mostram como toda a narrativa se sustenta na ideia de complô, da trama contra o Estado e mais, contra o status quo de toda a sociedade, ainda que abordada, como já apontado, através de uma construção narrativa distinta. Além disso, toda a relação dos personagens com o dinheiro nos remete a Arlt, que também tem no dinheiro e em seu papel na sociedade um núcleo temático básico de sua obra. Com a falsificação, o roubo, a ideia de "criar dinheiro do nada", acontece o mesmo: "No se gana nada trabajando - decía el Gaucho Dorda [...]” (PQ, p. 74). Do tesoureiro Martínez Tobar, um dos personagens que transportam o dinheiro que será roubado em Plata quemada, diz-se o seguinte (PQ, p. 31-2):

\begin{abstract}
Varias veces había pensado que era posible robar el dinero que le entregaban todos los meses. [...] A veces piensa que habría que llevar un portafolios igual y llenarlo de plata falsa. Sustituir uno por el otro y salir tranquilamente. Tenía que arreglar con el cajero que era un amigo de la infancia. Se dividían la plata y seguían viviendo una vida normal.
\end{abstract}

E se este personagem tão arltiano já não tivesse feito a troca por dinheiro falso nesse mesmo dia do roubo? E se tudo o que vem depois se dá ao redor de um monte de dinheiro

67 "He tratado de tener presenten en todo el libro el registro estilístico y 'el gesto metafórico' (como lo llamaba Brecht), de los relatos sociales cuyo tema es la violencia ilegal.”, PQ, p. 245-6. 
falso e esse narrador que nos deixa tantas lacunas em sua narrativa "não se deu conta" do truque? A partir do tema da falsificação em Arlt, não parece exagerado dizer que toda a trama de Piglia pode estar baseada em uma falsidade, que tudo o que se narra em Plata quemada pode ter outro sentido que não o aparente, o que a esta altura já não é dizer muito. Todos os interrogantes que nos deixa(m) o(s) narrador(es) da história nos mostram que as citações arltianas não são meramente ilustrativas, mas sim conformam uma narrativa, constroem uma maneira de contar a história. Seguindo-se o que afirma Compagnon em $O$ trabalho da citação: "Escrever, pois, é sempre reescrever, não difere de citar. A citação [...] é leitura e escrita, une o ato de leitura ao de escrita. Ler ou escrever é realizar um ato de citação.” (1996, p. 41) Mais do que uma alusão ao ambiente do lumpesinato arltiano, então, Plata quemada se constrói também como uma escritura originada da leitura de uma concepção arltiana de literatura a partir de sua forma, seus temas e suas obseções.

Também remete a Arlt o jornal onde trabalha Emilio Renzi, o diário El Mundo, de Buenos Aires, publicação real que circulou na argentina de 1928 a 1967 e que publicou originalmente as Aguafuertes porteñas do escritor argentino. $\mathrm{Na}$ realidade, apesar da constante presença da linguagem jornalística no texto e das menções aos meios de imprensa, El Mundo é um dos poucos destes meios citados nominalmente. Curiosamente, outro deles é o semanário uruguaio Marcha, que teve como secretário de redação Juan Carlos Onetti e como colaboradores nomes como Mario Benedetti, Eduardo Galeano e Ángel Rama. Assim, enquanto a maior parte da imprensa - especialmente os diários sensacionalistas - é retratada de maneira genérica, ganham relevo as publicações que não só se destacaram por suas posturas e atuações políticas, como também por suas relações com a literatura, através de seus colaboradores. Este papel de El Mundo e Marcha no romance acrescenta uma dose a mais de ambiguidade nas relações entre os discursos jornalístico e literário presentes no texto. 
Não se pode afirmar, entretanto, apesar de sua ambientação no submundo da sociedade, que se deve ler Plata quemada a partir de uma concepção puramente arltiana da literatura, ou que o romance seria uma "homenagem" de Piglia a Arlt antes de tudo. Ainda que uma referência importante no texto, a literatura de Arlt parece ser entendida em um contexto literário maior argentino, do qual igualmente encontramos citações no romance. Assim, podemos encontrar a história do primeiro assassinato cometido pelo Gaucho Dorada em uma reencenação de "El hombre de la esquina rosada", de Borges (2005, p. 109-25) - e a da Rusita, prostituta também assassinada por Dorda na juventude deste - relacionada a $L a$ cautiva, de Echeverría. O próprio Piglia parece colocar-se dentro desta miríade de citações ao sistema literário de seu país na história de Anselmo, o "gaucho matrero" que "había trabajado en el correo y empezó a abrir las cartas y robar la correspondencia y a escribir cartas a las mujeres y a visitarlas para violarlas, según decían.” (PQ, p. 231) - uma referência às cartas extraviadas de Respiración artificial?

Os muitos escritores e personagens mencionados como citações parecem conformar um texto literário que tem como uma de suas referências principais a própria literatura - mais, inclusive, do que o episódio real em que supostamente se basearia. E, mais do que isto, a profusão destas referências literárias, que as poderiam converter em mero exibicionismo vazio e confuso, parece apontar a um sistema maior: o da literatura (ou mesmo da cultura) argentina. Por isso, não parecem figurar por acaso em Plata quemada as cenas de estupro com Malito como estuprador de um policial ou com o Gaucho Dorda sendo estuprado por enfermeiros no manicômio - em que se evidencia a violência sexual associada à manifestação de poder por meio da humilhação. Se David Viñas (1974, p. 13) afirma que a literatura argentina "emerge alrededor de una metáfora mayor: la violación" e parte dos casos de $E l$ matadero, de Echeverría e Amalia, de José Mármol, poderíamos acrescentar a esta metáfora maior, a partir do qual a literatura argentina não só nasce, mas parece se desenvolver, 
inúmeros exemplos que atravessam a história literária e as diversas tendências estéticas no país: "Las Fieras", de Arlt; "Emma Zunz", de Borges; "El niño proletario", de Osvaldo Lamborghini; El frasquito, de Luis Gusmán; La pesquisa, de Juan José Saer. A presença do estupro em Plata quemada, então, pode ser entendida como uma citação à metáfora literária da opressão e subjugação por parte do poder na cultura argentina.

\section{A figura do gaucho}

Do mesmo modo que a "metáfora maior" do estupro na literatura, como grande figura perene na cultura argentina está a figura do gaucho, também presente no romance de Piglia como elemento fundamental na leitura feita aqui.

Os inúmeros personagens de Plata quemada poderiam ser classificados - e nomeados - em vários níveis: protagonistas - o Gaucho Dorda e o Nene Brignone -; coprotagonistas Malito, el Cuervo -; secundários importantes - Comisario Silva, Emilio Renzi -; funcionais chave - Nando, Blanca Galeano, Giselle, Roque Pérez, Lucía Passero, Dr. Bunge -; circunstanciais - Yamandú Acevedo, o tesoureiro Martínez Tobar, Fontán Reyes, o filósofo Washington Andrada e muitos outros. Embora pareça claro em qualquer leitura que todos os personagens, inclusive os que não têm nome, desempenham sempre algum papel fundamental para o desenvolvimento da trama e de sua melhor compreensão, também é evidente que Gaucho e Nene são os principais. É sua história, mais que a de qualquer outra, a que se narra. Assim, é inevitável perguntar por que o personagem mais desenvolvido do romance, Dorda, é chamado de gaucho, é chamado de Gaucho Rubio.

Marcos Dorda é para todos o Gaucho Dorda. Como personagem da ficção de Piglia que, como foi visto, não visa à reconstituição jornalística ou histórica dos fatos - poderia ser qualquer um, poderia ser só Dorda, poderia ser Marcos, poderia ser espanhol - como de fato é 
na adaptação cinematográfica de Marcelo Piñeyro, que, na verdade, o transforma em outro -, poderia, enfim, ser outro personagem. E, no entanto, é o Gaucho, não só porque os outros o vêm como e o chamam de "gaucho", mas sim porque ele se vê, se entende, se define como gaucho, como o sucessor daquele "gaucho matrero", Anselmo, a quem viu ir preso quando ainda era criança (PQ, p. 231).

A citação ao gaucho em Plata quemada não pode deixar de nos remeter ao paradigma do gaucho na literatura argentina: Martín Fierro. A questão é se Dorda seria um gaucho "paradigmático" e em que medida este personagem pode ser considerado uma citação ao clássico da literatura argentina. Algumas passagens do texto de Piglia guardam evidentes semelhanças com o de José Hernández: o clímax da ação de Plata quemada, com o cerco dos marginais pela polícia em Montevidéu, por exemplo, remete claramente ao cerco da polícia a Fierro, quando este consegue escapar junto a Cruz e fugir para o deserto. Por outro lado, também a figura de Dorda, sua construção como personagem, tem traços em comum com Martín Fierro. Ambos buscam, mais do que tudo, a liberdade individual, vista de maneira bem concreta na vida ao ar livre, nos espaços abertos, seja no campo, seja na selva urbana. Sempre, porém, uma vida sem caminhos predeterminados. Não se trata somente de uma liberdade de pensamento, mais do que isso se trata de uma liberdade de corpo e de ações, de buscar fazer o que se quer quando se tem vontade:

Mi gloria es vivir tan libre como el pájaro del cielo; no hago nido en este suelo ande hay tanto que sufrir y naides me ha de seguir cuando yo remonto el vuelo.

(El Gaucho Martín Fierro. v. 91-6. HERNÁNDEZ, 2002, p. 27) 
humillación y placer, de la que salía a la vez avergonzado y libre. Siempre suelto, siempre furioso [...] (PQ, p. 224)

Cuando llegaba a la loma, se descansaba, a la orilla del alambrado, por dos razones, porque se visualizaba, panorámico, el camino y porque en las lomas suele haber vizcacheras y se las puede agarrar con la ayuda de los perros. (PQ, p. 234)

Por isso em ambos se nota a aversão total ao encerramento, uma espécie de claustrofobia que se manifesta às vezes de maneira curiosa, como se inclusive grandes espaços fossem minúsculas celas, se não lhes dessem essa oportunidade de serem verdadeiramente livres:

\author{
Soy gaucho y entiéndanlo \\ como mi lengua lo explica: \\ para mí la tierra es chica \\ y pudiera ser mayor \\ (El Gaucho Martín Fierro. v. 79-82. HERNÁNDEZ, 2002, p. 27)
}

País de mierda, más chico que una baldosa. (Dorda, en el cerco, sobre el Uruguay; PQ, p. 169)

De todo modo, se as citações ao Martín Fierro parecem evidentes na figura do Gaucho Dorda e na narrativa de Plata quemada, tampouco é possível caracterizar o personagem de Piglia como uma "reencarnação" do gaucho de Hernández. Segundo o narrador do romance, Dorda inclusive não gostava do campo, ao passo que Martín Fierro a nada lhe dá mais importância que a sua vida nas estâncias. Pode-se dizer, então, que Dorda é outro gaucho, sem que deixemos de ver, no entanto, uma linhagem literária e cultural. A citação, aqui, se dá por um contraste e não por um decalque do original, sem que se perca a noção de referência ${ }^{68}$.

No final apocalíptico de Plata quemada, ainda que Dorda sobreviva, resta a impressão de que sua queda representa o fim do gaucho, o fim dessa tradição cultural - mais do que,

\footnotetext{
68 "[A citação] apela para a competência do leitor, estimula a máquina da leitura, que deve produzir um trabalho, já que, numa citação, se fazem presentes dois textos, cuja relação não é de equivalência nem de redundância." (COMPAGNON, 1996, p. 58-9)
} 
ainda que frequentemente também, política - que ele traz de Anselmo, de outros "gauchos matreros", de Martín Fierro, mas também dos gauchos de Bartolomé Hidalgo, de Ascasubi, de Martínez Estrada, inclusive de Don Segundo Sombra. Não obstante, tal impressão se revela também enganosa, já que desde Martín Fierro, ao menos, todos os gauchos da literatura argentina parecem ser o último, e aí podemos incluir também os de Borges - notadamente em "El fin", de Ficciones (2000, p. 249-56). Tendo este conto como tema uma questão deixada em aberto em Martín Fierro (a contenda entre Fierro e o Moreno), Beatriz Sarlo afirma que: "Borges está escribiéndole un final, a él y a todo el ciclo gauchesco que, de este modo, se incorpora a su propia literatura y clausura una historia abierta.” (1995, p. 65) Já Josefina Ludmer aponta que "Borges marca en ese punto el fin (en 'El fin') de esa otra cadena de usos que nace en La vuelta: el uso del género para producir literatura." (1988, p. 41) Assim, os gauchos são como os moicanos: sempre estamos contemplando "o último da espécie", o que significa uma transformação no personagem e uma mudança de ciclo e do uso que se faz dele. E admitindo-se isto, vale perguntar o que tal constatação significa em termos mais amplo, ou, dito de outro modo, o que representa o último gaucho na literatura argentina, ao menos como citação em Plata quemada.

Na leitura de Gisle Selnes, Nene é um personagem equivalente à figura de Cruz em Martín Fierro $^{69}$, o que não seria uma afirmação de todo equivocada, já que se pode ver uma relação bastante clara entre a ajuda de Cruz a Fierro para que este escape da polícia e um episódio em que Nene resgata Dorda em uma situação parecida narrada no romance (PQ, p. 79). Há, no entanto, ao menos uma diferença fundamental: tanto Fierro como Cruz são gauchos e têm inclusive uma história pessoal muito parecida. Dorda e Brignone, embora "mellizos" (gêmeos) para todos, embora extremamente unidos, não são "farinha do mesmo saco". Nene é um tipo da cidade, filho de um industrial, um pequeno burguês descarrilado,

\footnotetext{
69 "Another such figure is Nene, whom Dorda had first met in a reformatory and who later became his friend and lover, thus appearing as a contemporary equivalent to Fierro's companion, Cruz." (SELNES, 2006.)
} 
enquanto Dorda, nas palavras do narrador, "[e]ra provinciano provinciano, de una familia de inmigrantes piamonteses de María Juana, en la provincia de Santa Fe [...]” (PQ, p. 74). A citação de Piglia aqui parece ser de outro tipo.

Ao contrário de Martín Fierro, que se põe a cantar e a contar sua história, Dorda mal fala, não consegue se expressar e o Nene fala por ele - “[...] el Nene Brignone, que lo entendía cuando no podía hablar y decía siempre, el Nene, lo que el Gaucho sentía sin poder expresarse como si le leyera el pensamiento [...]” (PQ, p. 226). Indo além da citação literária a um personagem, o que parece haver aqui é uma citação extratextual ao modo de produção literária e à história da criação do mito gaucho na cultura argentina. Ludmer já aponta como a partir de Estanislao del Campo este processo - o de conformar o gênero não só a partir dos textos, mas também de aspectos extraliterário, como a biografia dos escritores - é fundamental na construção e no entendimento da gauchesca ${ }^{70}$. Em Plata quemada, o participar do gênero parece partir da mesma ideia, com o Nene podendo ser lido como referencia a José Hernández, tal como del Campo cria Anastasio el Pollo a partir de Aniceto el Gallo, "nombre de [Hilario] Ascasubi en el género", nas palabras de Ludmer (1988, p. 123). No caso do clássico maior da gauchesca, se "dentro" da obra Martín Fierro conta sua própria história, a verdade é que José Hernández não é um gaucho e seu discurso obedece a uma oposição política a um projeto de nação específico, encarnado na figura de Sarmiento. O Nene, como Hernández, tampouco é um gaucho, mas também lhe empresta a voz. Além disso, como Hernández, havia vivido no Brasil - "Viví en Brasil, gil, no te dije.” (PQ, p. 204). Seguindo por esta leitura, podemos chegar a um novo significado das citações como elemento constituinte da narrativa de Piglia em Plata quemada: o Nene em especial, mas também

\footnotetext{
70 "Del Campo amplió los límites del género a tal punto, que con él las biografías de los escritores del género pasaron a formar parte de la genealogía misma del género." (1988, p. 125) Ludmer também aponta a reciprocidade que existe neste movimento de justaposição, mescla e união entre o literário e o social e histórico, no caso da gauchesca: "El ciclo abierto con Hidalgo se cierra con Hernández. Allí el nombre del gaucho nombra al que lo nombró: 'Ayer falleció el senador Martín Fierro', se escribió en un diario cuando murió Hernández [...]” (Ibid., p. 128).
} 
outros personagens e os narradores, ao contar a história de Dorda, reescrevem o mito do gaucho, desse "último gaucho".

Dorda é o único que sobrevive ao cerco da polícia e, ainda que morra um ano depois, tem um final digno sob o ponto de vista do gaucho: morre na Argentina e sem "se dobrar", sem fazer concessões. Parece significativo também que morra na prisão de Caseros, lugar, como se sabe, representativo da queda de Rosas e do começo do triunfo - ainda que não imediato, e sim futuro - do projeto de nação sarmientino. O fim do Gaucho Dorda, como o fim dos outros "últimos gauchos" da literatura argentina, parece, então, estar carregado de significações e especialmente de previsões.

Se Martín Fierro canta suas dores e tragédias, assimilado, no fim das contas, também apresenta - ou representa - a Argentina moderna e unificada sob os preceitos liberais. O fim de Martín Fierro, especialmente marcado por não ser uma morte, mas sim uma espécie de capitulação, supõe um triunfo da legalidade estatal, de um modelo liberal, de ideias europeístas, da sociedade urbana burguesa sobre a vida tradicional campesina. De todo modo, supõe um embate ideológico e a imposição de uma legalidade. O que sucede Martín Fierro é um projeto nacional para a Argentina - bom ou mau, e para quem, não vem ao caso discutir aqui. A mudança de status social do gaucho conforme avançava o século XIX parece ser assunto conhecido até de Nene, que afirma que se o amigo "hubiera nacido en la época del general San Martín, el Gaucho, decía el Nene, bueno tendría un monumento. Sería no sé, qué sé yo, un héroe, pero nació fuera de época.” (PQ, p. 79). Já está claro, então, mesmo na visão dos personagens, que, nem heroico, nem assimilado, o fim de Dorda prenuncia sem dúvida tempos muito mais negros. O que morre com Dorda e o que seu fim prenuncia se converte, assim, numa questão chave na interpretação do romance.

Como aponta Germán García, no início do romance "[e]l comisario Silva dice que todos los crímenes tienen un signo político, pero después habla de que sólo se trata de 
criminales y por último los califica de enfermos mentales.” (2001) Há uma tentativa clara de eliminar das ações dos bandidos qualquer conotação política, ainda que esteja evidente, a partir da epígrafe do romance, que roubar um banco e, além disso, queimar o dinheiro do roubo são atos sumamente políticos. O sentido político que se mata com os bandidos é o choque ideológico que se representava em Martín Fierro. Voltando a Ludmer (1988, p. 134):

[E]n el género se discute el lugar y la función del gaucho en la distribución social y el tipo de relaciones que pueden establecerse entre él y los otros sectores, políticos y letrados, pero esa discusión no es parlamentaria, periodística ni meramente política: se disputa eso en la voz (del) "gaucho", en el espacio de su emisión, sus direcciones y sentidos.

Ainda segundo Ludmer, é no contraste entre duas culturas, duas "línguas-leis", que se forma o gênero gauchesco. Sobre Martín Fierro, afirma que "muestra la existencia de dos órdenes jurídicos y muestra que uno de ellos, usado de un modo diferencial, según las lenguas, pone al otro fuera de la ley." (1988, p. 232) De todo modo, há duas ordens jurídicas, mesmo que uma se imponha injustamente no intuito de alienar a outra.

Já a narrativa de Plata quemada não parece apresentar nenhuma discussão ou projeto nacional que suceda a eliminação do gaucho, ou a de qualquer das figuras "criminais" da sociedade. Dito de outro modo, não há lei que se imponha, o que desnuda a criminalidade da sociedade inteira. Diz o narrador sobre o comissário Silva (PQ, p. 66):

El comisario Silva, de Robos y Hurtos, no investiga, sencillamente tortura y usa la delación como método. [...] Había armado un escuadrón de la muerte siguiendo el modelo de los brasileños. Pero actuaba legalmente, Silva, tenía el respaldo de Coordinación porque su hipótesis era que todos los crímenes tenían un signo político. [...] Por eso (según Silva) había que coordinar con la Inteligencia del Estado la acción policial y limpiar la ciudad de esta bosta.

Configura-se nitidamente na passagem acima o grau de deterioração da sociedade, representado na fala do narrador que conta de maneira impassível que Silva "atuava 
legalmente" torturando; que, acompanhando o raciocínio do comissário, apresenta a hipótese de eliminar da sociedade o "signo político" que representa o crime. A assimilação imposta a Martín Fierro - ainda que implicasse o fim de uma cultura e de um modo de vida - é substituída pela aniquilação imposta ao Gaucho Dorda e a seus companheiros, aos párias da sociedade.

Em Plata quemada, quando morrem Dorda e o Nene Brignone, o gaucho morre com sua voz, mas, além disso, morre também o Cuervo Mereles, o bandido charmoso e sedutor, corruptor de jovenzinhas rebeldes e ingênuas de classe média. Por sua vez, Malito, o intelectual, o "cérebro mágico", desaparece. Um mundo de representações, então, morre com os fatos que se seguem ao roubo em San Fernando e as citações de Piglia encontram novos significados quando o autor as mata pouco a pouco na história. Já o Epílogo nos traz um narrador que conta a construção do texto mais de 30 anos depois dos "fatos reais". Se as citações de Piglia voltam a recobrar sua voz, é como se esta ressoasse do além, de um passado morto, que adquiriu "la luz y el pathos de una leyenda" (PQ, p. 245).

O gesto antissocial do roubo, bem como a loucura da queima do dinheiro, adquire por esta leitura o sentido de agonia de uma mitologia: a de um sistema político, cultural e simbólico de uma nação. A "plata” que queima é, portanto, também o Plata que queima, um modo de entender a Argentina que desaparece, substituído por um sistema que já não respeita fronteiras e que trata de apagar ideologias e "gestos políticos" - como se isto não fosse, por si só, um imenso gesto político - em defesa do dinheiro "inocente": o sistema do capitalismo financeiro multinacional e absoluto.

O gesto de Plata quemada de narrar a história dos marginais ao mesmo tempo em que procura narrar uma "história futura" ou o "futuro da história passada" o aproxima, mais do que parece à primeira vista, de Respiración artificial e de La ciudad ausente, e o situa de maneira bastante coerente na obra de Piglia e em sua práxis narrativa. 
Vale recordar, ainda, o que diz Edgardo Berg, em “Asesinos por naturaleza: sobre Plata quemada de Ricardo Piglia”, acerca do romance de Piglia e da adaptação cinematográfica feita por Marcelo Piñeyro: "La apuesta que hace Piglia con Plata quemada no es la que propone Marcelo Piñeyro - quien transforma una historia de fuerte conflictividad social en el relato de una relación casi adolescente de una pareja gay [...]. (2001, p. 97)

Ainda segundo Berg, não só é evidente que a leitura de Piñeyro e Marcelo Figueras roteiristas - privilegia um aspecto menor do romance, como também que essa leitura parece dirigida a (e por) uma estratégia de captação de mercado que tem como alvo um público adolescente e jovem. Além do que aponta o crítico, há outro aspecto importante: não há, no filme, o personagem do Gaucho Dorda. Em seu lugar, desempenhando um papel análogo, está Ángel, um espanhol apaixonado por Nene, com quem forma o casal gay. Além de centrar a narrativa do filme na relação entre os dois, é significativo que o gaucho seja substituído por um espanhol, o que evidentemente invalida toda leitura análoga entre filme e livro que se faça do romance desde o ponto de vista que se tem desenvolvido aqui. É curioso ainda que a mudança pareça ser produzida também por exigências de mercado: uma parte da produção do filme é espanhola, portanto é interessante ter um ator espanhol conhecido, inclusive com vistas a sua projeção internacional. Uma vez mais morre o gaucho e, no entanto, não há desta vez quem recupere sua história, mesmo que muito tempo depois. A justificativa que parece restar é cruelmente irônica: o que é escrever um livro para milhares de leitores em comparação com fazer um filme para milhões de espectadores?

\section{A política e a história}

As declarações do comissário Silva à imprensa, em Plata quemada, são, segundo o narrador, ao mesmo tempo peremptórias e contraditórias, "como cuadra al razonamiento 
policial.” (PQ, p. 87). Assim, entre as especulações sobre vinculações políticas, revolucionárias e militares do grupo de assaltantes fugitivos e outros envolvidos em toda a trama - supostos ou confirmados -, abundam as informações desencontradas, especialmente aquelas cujas fontes são a própria polícia - que, por sua vez, também faz da desinformação uma estratégia:

La policía estaba siguiendo una línea de investigación en la que elementos del nacionalismo peronista habían comenzado a operar con delincuentes comunes [...] (PQ, p. 53)

Las informaciones en los diarios circulaban entre líneas y había muchas operaciones de contrainteligencia en medio de las noticias. [...] (PQ, p.54)

[...] la investigación ha abierto un cauce hacia los presuntos contactos militares de la banda. (PQ, p.55)

Pese al mutismo de los jefes policiales trascendió que surgieron pistas firmes que llevarían a los investigadores hacia los contactos políticos de la banda. (PQ, p.58)

La situación era confusa; la policía trataba de ocultar lo que sabía, parecían estar desorientados y tendían a ligar el asalto con los grupos de derecha del peronismo. (PQ, p.65)

[...] y agregó el jefe de la policía "no son tacuaras ni peronistas de la resistencia, son delincuentes comunes, psicópatas y asesinos con frondosos prontuarios". (PQ, p.91)

Por outro lado, é clara a presença política, especialmente do peronismo proscrito e de suas organizações clandestinas, atravessando a trama. Desde a ideia do roubo, sugerida por um velho cabo-eleitoral peronista e seu filho (Nino e Carlos Nocito), ambos políticos em San Fernando; passando por Nando Heguilein, um ex-integrante da Alianza Libertadora Nacionalista - organização extinta anos antes -; muitos são os personagens que mantém 
relações ambíguas com o peronismo e com lutas políticas e de guerrilha ${ }^{71}$. Estes vão desde os mais ou menos idealistas, como Nando ${ }^{72}$, aos que, no máximo, tomam a efervescência política como álibi para ações criminosas ou como estratégia de sobrevivência. Neste último caso estão Malito, que havia conhecido Nando na prisão e com que se dava bem, até o Nene Brignone, que ironicamente afirma: "En la cárcel me hice puto, drogadicto, me hice chorro, peronista, timbero [...]" (p. 94). Na verdade, Nene não gostava de Nando, "un gil como todos los giles que se hacían matar por el Viejo [Perón]”. Em suma, reina aqui também o acúmulo de informações contraditórias de citações políticas e históricas e, ao fim, nunca se sabe qual o engajamento, se houve algum, do bando de assaltantes em organizações políticas, clandestinas ou não. Tampouco se elucida a participação de autoridades do Estado - políticos, policiais, militares - no roubo e na fuga.

O embaralhamento de citações ao campo político e histórico, entretanto, reassume, por estas características, significados mais amplos quando vistos em conjunto. Em primeiro lugar, evidencia-se um momento histórico de grande diversidade e ambiguidade política, mesmo entre os que defendiam o peronismo e a volta de Perón ao país ${ }^{73}$. Em segundo lugar, torna-se patente a tênue linha que separava o Estado e a legalidade e sua contrapartida social no submundo da ilegalidade, criminal e política - "en una combinación explosiva que tenía muy preocupadas a las autoridades" (PQ, p. 53) -, encarnada de maneira bastante clara na figura do personagem que passa à quadrilha as informações sobre o carregamento de dinheiro em San Fernando (PQ, p. 87-8):

\footnotetext{
${ }^{71}$ São citados em diversas passagens do romance personagens, instituições e situações históricas reais ligadas ao movimento clandestino ou guerrilheiro peronista. Um exemplo é o paralelo que se faz entre o roubo em San Fernando e o assalto ao Policlínico Bancario, realizado pela organização clandestina Tacuara, também citada, bem como seus líderes José Luis Nell e Joe Baxter.

72 "Nando tenía la ilusión de hacerlos entrar en la Organización. Poner caños, robar bancos, cortar líneas eléctricas, provocar incendios, disturbios. Las cosas habían salido al revés [...]” (PQ, p. 64)

73 Além da Tacuara, organização a princípio de extrema direita,que depois gera uma dissidência marxista liderada por Nell e Baxter, citam-se a Alianza Libertadora Nacionalista e seus líderes Queraltó e Guillermo Patricio Kelly, a CGT (Confederación General del Trabajo), a Guardia Restauradora Nacionalista e a UOM (Unión Obrera Metalúrgica), todas ligadas ao peronismo e/ou ao nacionalismo, mas com ideologias e estratégias de ação extremamente diversas e, não raro, contraditórias.
} 
Carlos A. Nocito [...] era un influyente, un hombre que hacía favores en la zona, un típico puntero que bordeaba las actividades delictivas. En otro lugar habría sido un hombre de la mafia pero aquí se dedicaba a pequeños negocios en los que entraba la coima y la protección a quinieleros y quilombos clandestinos.

Por fim, como no simbólico fim de Dorda, no fim cultural do "último gaucho", representa-se um momento histórico de quebra da legalidade e início dos anos negros de autoritarismo que se seguiriam não só na Argentina como na América Latina como um todo. Neste sentido, Plata quemada parece adquirir o sentido de hecatombe para uma geração intelectual e política e de profecia assustadora do que se estava gestando, como um "ovo de serpente", e do que viria em seguida, culminando, por outro lado, no neoliberalismo dos anos 90, quando se publica o romance. Por isso, talvez, para os que pereceram no cerco, o maior e talvez único - objetivo a ser alcançado era a sobrevivência, mais do que a construção de uma realidade política. Por isso, o desprezo de Nene com relação aos militantes que esperavam e lutavam pela volta de Perón: "La vuelta, las pelotas [...], lo único que tenemos en común es que nos picanean para averiguar si somos muñecos de la CGT”. (PQ, p. 61)

Nesse contexto, é o comissário Silva, "un tipo profesional, inteligente, bien preparado, pero muy fanático" (PQ, p. 61, grifo meu), quem, apesar de suas declarações contraditórias, se configura como um personagem implacavelmente coerente. Seu papel de aniquilador é tão claro como as ideias que o norteiam (PQ, p.65-6):

El comisario Silva, de Robos y Hurtos, no investiga, sencillamente tortura y usa la delación como método. [...] Había armado un escuadrón de la muerte siguiendo el modelo de los brasileños. Pero actuaba legalmente, Silva, tenía el respaldo de Coordinación porque su hipótesis era que todos los crímenes tenían un signo político. 'Se terminó la delincuencia común', decía Silva. 'Los criminales ahora son ideológicos. Es la resaca que dejó el peronismo. [...] Son delincuentes sociales, son terroristas [...]. Son como los argelinos, están en guerra con toda la sociedad, quieren matarnos a todos.' Por eso (según Silva) había que coordinar con la Inteligencia del Estado la acción policial y limpiar la ciudad de esta bosta. 
A aniquilação, a "operação de limpeza", conduzida por Silva e pelo Estado ${ }^{74}$, particulariza no episódio do roubo e da fuga dos criminosos uma concepção de sociedade que se quer instaurar sob a falsa imagem de restauração da ordem. O comissário sabe do falso "ar de tranquilidade" que permeia a sociedade, mas também sabe da existência de um discurso social que o cria: "Hay crímenes, adulterios, robos, pero uno anda por las calles y todo se mueve normalmente y con el aire de falsa tranquilidad que los mismos transeúntes le dan a las cosas.” (PQ, p. 86). Na narrativa de Plata quemada, quando este discurso falsamente tranquilizador, mas, no fundo, alienante, é colocado em perigo - os criminosos mostram o quanto se está longe de viver em uma sociedade justa e harmônica -, tratam de salvá-lo os discursos oficiais, policiais, jornalísticos, de toda parcela, enfim, considerada por si mesma como "de bem" dentro da sociedade. A solução para o ruído perturbador pode vir por meio de um cinismo disfarçado de ingenuidade - "Así epiloga un suceso inaudito en el que personas aparentemente honestas alquilaron asesinos a sueldo para cometer un hecho vandálico. ${ }^{75,}$ (PQ, p. 91) -; pela eliminação do ruído no discurso oficial - "Había que matarlos para que no hablaran.” (PQ, p. 195) -; ou pela intimidação autoritária e irônica, como em um diálogo entre Silva e Renzi, durante uma entrevista (PQ, p. 196-7):

- Son enfermos mentales.

- Matar enfermos mentales no está bien visto por el periodismo. - ironizó el cronista.- Hay que llevarlos al manicomio, no ejecutarlos... [...]

- ¿Y matar sanos está bien visto? - contestó Silva con la voz desganada del que tiene que explicar lo que para cualquiera es evidente. [...]

- Estos señores son psicópatas, homosexuales. - Miró a Renzi. - Casos clínicos, basura humana.

\footnotetext{
74 “[Silva] Tenía una serie de ideas extravagantes sobre el futuro político y el avance de los comunistas y de los grasas. [...] La policía brava de la provincia de Buenos Aires venía llevando una campaña de exterminio. Mataban a todo el que encontraban y no querían presos. Y habían encontrado apoyo en el jefe de la Coordinación Federal que veía venirse la maroma en cada huelga." (PQ, p.66-7, grifo meu)

${ }^{75}$ A referência ao acontecimento "inaudito" associado a "pessoas aparentemente honestas" parece confiar não só na ingenuidade do leitor, como no seu completo desconhecimento da história do funcionamento das sociedades, não só na América Latina, como no mundo inteiro!
} 
Como nota final sobre as citações políticas e históricas do romance, pode-se destacar que o momento de gestação de uma nova e terrível etapa histórica simbolizado nos anos de 1965 e 1966 - anos em que se passa a trama do romance - não é só significativo para a Argentina, como também para o Uruguai e o Brasil, mencionados no texto. No primeiro, a autodenominada "Revolução Argentina" de 1966, com um golpe que instaura uma ditadura militar, será prenúncio do ainda mais terrível "Proceso de Reorganización Nacional", ditadura sanguinária instaurada também por golpe militar, dez anos depois. O Uruguai, por sua vez, enfrenta o governo autoritário de Jorge Pacheco Areco a partir de 1967, seguido pela ditadura militar, a partir de 1973. Figura emblemática deste período autoritário, inclusive, o juiz José Pedro Púrpura - acusado de envolvimento em esquemas criminosos, esquadrões da morte e espionagem para a CIA - é citado, ironicamente, no romance, como "fiador" da garantia, dada pela polícia aos bandidos entrincheirados no apartamento, de que suas vidas seriam preservadas, caso se entregassem (PQ, p. 153). Por fim, o Brasil, que já vivia uma ditadura militar, aparece como uma espécie de inspiração ou escola para a linha de atuação de Silva: daí vem seu modelo para as campanhas de extermínio de criminosos e a montagem de esquadrões da morte. Ironicamente, em Plata quemada como também na história brasileira, a criminalização da política e a politização do crime - pela atuação do Estado em vários níveis e situações, como a de colocar criminosos "comuns" e políticos para dividirem a mesma cela - terá sequelas sentidas até hoje, do atraso no desenvolvimento das instituições políticas à sofisticação alcançada por organizações criminosas.

\subsection{A colagem de gêneros em Plata quemada}

Estabelecidas as citações e os múltiplos e vacilantes narradores como conformadores da práxis narrativa desenvolvida em Plata quemada, não muito distante da levada a cabo no 
restante da obra de Piglia, pode-se passar à questão do gênero literário dentro desta mesma práxis. Dito de outro modo, e concebendo-se aqui o conceito de gênero essencialmente como uma perspectiva ou expectativa de leitura, ou um jogo proposto pelo escritor com esta expectativa, é possível se analisar a narrativa do romance como constituída a partir de sua leitura como um romance policial, um livro-reportagem, uma tragédia modernizada, etc. A configuração ambígua e fragmentada do texto acaba por facilitar esta multiplicidade de leituras, ainda que não obrigue - ao menos não necessariamente - à escolha de somente uma delas e da exclusão das demais. Ao mesmo tempo, o que se propõe aqui não é o aprisionamento da leitura, não é a adequação de Plata quemada a regras arbitrárias e apriorísticas relativas aos gêneros literários. Ao contrário, o que se propõe é a observação do romance em diálogo com os gêneros, participando deles e expandindo-os, e não submetido a eles.

Ricardo Piglia cultiva a imagem da leitura de forma reiterada em sua obra de ficção tanto quanto em sua obra crítica - chega a dedicar a esta imagem exclusivamente um de seus livros, El último lector. Em Respiración artificial, as leituras de cartas, diários, a leitura crítica da literatura argentina formam o tecido mesmo da trama e uma realidade se constrói menos pelas ações dos personagens do que pela literatura que os rodeia. Isto pode também ser interpretado como uma realidade construída pela representação e pelo artifício que estão no cerne da literatura e dar um sentido à imagem da "respiração artificial" do título. O personagem de Emilio Renzi, espécie de alter ego do escritor - um alter ego tomado com ironia e por vezes paródico, segundo o próprio Piglia - é descrito por ele, em uma entrevista dada a Carlos Damaso Martínez em 1985 e publicada em Crítica y ficción, como um personagem a quem "sólo le interesa la literatura, vive y mira todo desde la literatura" (2001a, p. 93) Assim também parece ser a literatura ficcional de Piglia: uma vivência e um olhar da realidade a partir dos discursos que permeiam a sociedade, como o são os próprios textos 
literários. Em outra entrevista, dada quatro anos depois a Ana Inês Larre Borges e também publicada em Crítica y ficción ("La literatura y la vida", 2001a, p. 110), a descrição praticamente se repete:

Renzi está construido con algo que yo veo en mí con cierta ironía y con cierta distancia. En el sentido de que a Renzi sólo le interesa la literatura, habla siempre con citas, vive "literariamente" y es lo que yo espontáneamente hago o quiero hacer pero que controlo a través de mi conciencia política, digamos, una relación diferente con la realidad. Entonces es como si de entrada el personaje se hubiera constituido como el lugar desde el cual el mundo puede ser visto desde el estilo, desde las tramas. En este sentido Renzi es una autobiografía.

Se Renzi, o personagem, expressa certa auto-ironia do escritor, os textos - romances, contos - podem ser lidos todos como "respirações artificiais": mais do que simplesmente literatura de ficção, uma representação da realidade feita em termos literários, uma visão do mundo que passa pela leitura, que passa pela criação do real pela ficção ou, ao menos, pelo texto. Neste contexto, um mundo que pode ser visto "a partir do estilo e a partir das tramas", pode também ser filtrado a partir dos gêneros literários, vistos, repita-se, como uma perspectiva de leitura.

\section{Plata quemada como narrativa policial}

Ler Plata quemada como romance policial não parece, a princípio, motivo de grande discussão e é o que a maioria dos leitores, ao menos em um primeiro momento, fará. Há inclusive na crítica trabalhos que partem explicitamente desta leitura, como "Plata quemada o un mito para el policial argentino", de Adriana Rodríguez Pérsico (PÉRSICO, 2004, p. 11321). De qualquer modo, assumir este ou qualquer outro romance como policial a priori pressupõe uma discussão ampla e espinhosa: de fato o romance pertence ao gênero policial? Quais as regras do policial? Como definir a noção de "gênero" na atualidade? O próprio autor 
aborda muitas vezes estas questões e as relações entre seus textos ficcionais - não somente Plata quemada - e o gênero.

Em vários de seus textos críticos, como "Los relatos sociales", entrevista publicada em Crítica y ficción (2001, p. 101-8), Piglia discorre sobre o crime, os transgressores da lei e a sociedade "policialesca", os relatos do Estado. Este, ao se tornar opressor, totalitário ou violento, conforma uma realidade "lida" por seus textos em termos literários. A construção do real - como, por exemplo, a ficção gerada pelo Estado - assume assim, muitas vezes as formas do gênero policial e dos seus subgêneros mais violentos. A sociedade se constrói, ou se entende, seguindo a lógica de um gênero literário, ainda que este "real" seja só o real dos textos de Piglia. Esta leitura do real que conforma sua literatura e que aparece também em muitos de seus textos críticos se evidencia na ligação de Piglia com o gênero policial. Como editor, a partir de 1968, dirige na Argentina a "Serie Negra", coleção de romances policiais norte-americanos publicada pela editora Tiempo Contemporáneo. Por fim, trabalha de diversas formas com o gênero em seus contos e romances, seja pela clave do policial de enigma - "La loca y el relato del crimen" -, seja pela do policial noir, ou do hardboiled norteamericano - Plata quemada.

A ligação da ficção de Piglia com o policial assume características múltiplas, desde citações mais ou menos explícitas a obras do gênero, até uma concepção e conformação da narrativa mais ampla, como se verá mais adiante. Entre as citações mais explícitas em Plata quemada podem-se destacar algumas e ver que, como nos exemplos de citações vistos anteriormente, estas não se prestam ao papel de meras curiosidades, e sim ao de peças em uma arquitetura maior da narrativa. Assim, foi possível ver como a descrição de Dorda e Nene no primeiro parágrafo do romance - calcada na descrição de Sam Spade, no primeiro parágrafo de $O$ falcão maltês, de Hammett, como visto no início deste capítulo - serve como ponto de partida "seguro" de um narrador onisciente para a posterior fragmentação das 
instâncias narrativas. O mecanismo funciona pela citação do gênero, estabelecendo um limite seu, para uma posterior transgressão.

Ainda dentro do âmbito do policial norte-americano, é bastante clara a referência a They Shoot Horses, Don't They? (1935), de Horace $\mathrm{McCoy}^{76}$. Neste romance, ambientado na Grande Depressão e narrado em primeira pessoa pelo assassino, este justifica seu crime como um "ato de piedade": a vítima, sua companheira de dança, desesperada e sem nenhuma perspectiva na vida, implora pelo fim - "Me mate. É o único jeito de sair desta miséria" - e é atendida pelo narrador - “'Ela tem razão’, eu disse para mim mesmo. 'É o único jeito de livrála desta miséria"” (McCOY, 1982, p. 151). Do mesmo modo, Dorda, ao ser preso e agredido de maneira selvagem, pensa a respeito da Rusita, a quem havia matado antes de ser enviado pela primeira vez ao manicômio: "Tal vez si pudiera confesarse, podría hacerse perdonar, podría explicar al menos porque había matado a la colorada [La Rusita], porque las voces le dijeron que ella no quería seguir viviendo.” (PQ, p. 241). O evidente paralelo entre as duas situações não deixa, contudo, escapar a diferença fundamental: o desespero - sentido na própria pele e na companheira - do narrador de McCoy é diferente da manifestação de esquizofrenia do Gaucho Dorda. Ainda assim, é possível ir além na citação. Piglia, em "Sobre el género policial", menciona que em They Shoot Horses, Don't They? - no escopo de certa linha norte-americana de policial - o único enigma é o das relações capitalistas: "el dinero que legisla la moral y sostiene la ley es la única 'razón' de estos relatos donde todo se paga" (2001, p. 62). Assim se dá também em Plata quemada: Dorda, atormentado e doente, é mandado aos cuidados do Dr, Bunge, para que, forçado a base de injeções de insulina e eletrochoques, fosse como todos: "Fue el Dr. Bunge [...] el primero que le empezó a decir que tenía que ser igual a todos." (PQ, p. 224). No fim, ambos os personagens - o de McCoy e

\footnotetext{
${ }^{76}$ Mas não se mata cavalo?, 1982. Não por acaso, este foi um dos livros editados por Piglia na "Serie Negra".
} 
o de Piglia - se mostram inúteis e descartáveis para a sociedade, transgressores de sua lei que garante, antes de tudo, um papel em sua ordem econômica como indivíduos.

Por outro lado, se esta vertente da literatura policial - eminentemente norte-americana - goza de maior simpatia por parte de Piglia, especialmente por suas relações com um discurso político e uma discussão social crítica mais explícitos, não faltam citações em Plata quemada que remetem também ao policial de enigma - a vertente mais "tradicional" e de origem inglesa. Estas podem revelar-se simplesmente irônicas - como quando Renzi descreve o edifício do cerco, que não tem elevador, e diz que "Hay que retener este detalle." (PQ, p. 143), sendo que o detalhe não tem nenhuma importância para a compreensão da trama, nem será a chave para a resolução de nenhum enigma posterior ${ }^{77}$ - ou desdobrar-se em conotações mais profundas. Uma referência ao gênero policial importante que parece desdobrar-se mais profundamente na estrutura do romance está na figura de Malito, descrita assim pelo narrador (PQ, p. 13):

Era el hombre invisible, era el cerebro mágico, actuaba a distancia, tenía circuitos y contactos y conexiones raras. [...] Malito era el jefe y había hecho los planes y armado los contactos con los políticos y los canas que le habían pasado los datos, los planos, los detalles y a quienes tenían que entregarles la mitad del paquete.

Aqui o modelo pode ser Moriarty, arqui-inimigo de Sherlock Holmes, retratado por Conan Doyle da seguinte forma, em “O problema final” (2010a, p. 349):

Ele é o Napoleão do crime, Watson. É o organizador de metade do que se faz de errado e de quase tudo que passa despercebido nesta grande cidade. É um gênio, um pensador abstrato. [...] Ele mesmo não

\footnotetext{
${ }^{77}$ Em O misterioso caso de Styles, de Agatha Christie, Poirot diz a seu amigo Hastings - o narrador da história -, ainda antes da metade da trama: "O termômetro registrou vinte e seis graus à sombra. Não esqueça disso (sic), meu amigo. Aqui temos a chave de todo o enigma." (2003, p. 85) Tal procedimento, de sinalizar ao leitor pistas que podem ser fundamentais para o desvendamento do enigma - mas que também podem ser pistas falsas ou insignificantes -, é bastante comum nas narrativas de detetives como Poirot e outros de sua linhagem dentro da narrativa policial em sua vertente de enigma.
} 
faz muita coisa. Apenas planeja. Mas seus agentes são numerosos e esplendidamente organizados.

Como já foi visto anteriormente, Malito pode ser considerado - como aponta Michelle Clayton (PÉRSICO, 2004, p. 135-44) - uma figura de autor e uma das instâncias narrativas na construção do romance, por suas ações na construção da intriga. $\mathrm{O}$ paralelo com Moriarty ressalta, então, a contraparte marginalizada e criminal da sociedade como também produtora de discursos e realidades, ainda que ocultos para os "cidadãos de bem". O desaparecimento de ambos no final de cada história - Plata quemada e "O problema final", único conto em que Moriarty interage efetivamente com Sherlock Holmes - e suas obscuras relações com instâncias do poder também coincidem, deixando em aberto a questão sobre sua morte ou sua volta às sombras, de onde seguiriam atuando. Por outro lado, é evidente o esquema muito mais maniqueísta no texto de Conan Doyle - onde Moriarty encarna o mal enquanto Holmes é um baluarte da justiça e da ordem pública - que no de Piglia - onde Malito se reveste de mistério e ambiguidade e não se diferencia muito, em sua "maldade", do comissário Silva, por exemplo. A voz do submundo social, em Plata quemada, questiona e se confunde muito mais com o status quo, pondo em xeque, por exemplo, o papel que representa o dinheiro na sociedade. A clara ordem pública e social vitoriana a ser defendida, como retratam as narrativas de Holmes - ainda que falsa, historicamente - se contrapõe claramente ao ambiente autoritário e violento que se vai criando na Argentina a partir de meados dos anos 1960, tal como o retratado por Piglia.

Por fim, como que reforçando ironicamente esta contraposição entre Inglaterra vitoriana e Argentina entrando em anos de terror, está a figura do Dr. Bunge, no retrato que faz do Gaucho Dorda. Todo o cientificismo positivista da virada do século XX, tão presente também nas narrativas detetivescas da época, se manifesta no psiquiatra como um anacronismo sádico e mais um meio de controle social. Em um momento, Bunge anota em 
sua ficha que Dorda é “[p]eligroso, psicótico, invertido. Mal de Parkinson.” (PQ, p. 78). Mesclando percepções subjetivas ("perigoso”) com diagnósticos psiquiátricos ("psicótico”) e neurológicos ("mal de Parkinson”), o médico chega à patologização da homossexualidade, usando, inclusive, uma terminologia inadequada e depreciativa ("invertido"). Como coroamento das práticas do Dr. Bunge, está uma espécie de resgate da frenologia lombrosiana na caracterização de Dorda (PQ, p. 72):

[...] él era bizco pádentro (como decía su finada madre) un estrabismo convergente, que le daba ese aspecto de tipo obsesivo, muy peligroso, que es lo que es (informa el Dr. Bunge).

Dorda tiene entonces la cara perfecta de la clase de sujeto que representa (agrega el Dr. Bunge) [...]

A semelhança com uma das descrições de criminosos nas histórias de Sherlock Holmes - a de Sebastian Moran, curiosamente, um dos agentes de Moriarty - não deve ser gratuita (“A casa vazia”, CONAN DOYLE, 2011c, p. 26):

Era uma face extremamente viril e ao mesmo tempo sinistra que se voltava para nós. [...] Mas não se podia fitar seus cruéis olhos azuis, com suas pálpebras caídas, cínicas, ou o nariz feroz, agressivo, e a testa ameaçadora, com rugas profundas, sem ler os mais claros sinais de perigo da natureza.

O Dr. Bunge se caracteriza, portanto, como uma figura pseudocientífica, preconceituosa e, ao mesmo tempo, sádica e medrosa, cujo único propósito parece ser o de aplicar uma filosofia pretensamente sanitarista em prol da manutenção da sociedade constituída. Que suas concepções se associem às muitas vezes presentes nos relatos de enigma clássicos da virada do século XX parece apontar a uma crítica sutil a esta vertente do gênero, sempre protagonizada pelo detetive racional e imbatível na manutenção da ordem em uma sociedade modelar e imaculada. Novamente se constatam, então, as diferenças entre este 
modelo de policial e o de Plata quemada, onde o status que pretende manter o Dr. Bunge se revela corroído pela corrupção e a violência e seus métodos, sádicos e cínicos.

Percebe-se, então, pelas citações e os paralelos entre Plata quemada e personagens e situações típicas do gênero policial, que a narrativa vai estabelecendo uma relação com o gênero "desrespeitando" muitas vezes seus cânones, acrescentando-lhe ou sacando-lhe algo, subvertendo-lhe certos parâmetros. De todo modo, há, além das referências pontuais, uma concepção da narrativa policial que perpassa todo o romance - e outros textos do autor - em que o modo de ler o gênero parece fundamental.

Conformar sua literatura com leituras, releituras e citações de leituras, ao mesmo tempo em que conforma sua "realidade" literária baseando-se fortemente na ideia do crime, do delito e da violência conduz, naturalmente, a uma ideia muito explorada por Piglia: mesclar os dois temas - a leitura e o policial -, reiterando a imagem do escritor como criminoso - transgressor - e do leitor, especialmente do leitor-crítico, como detetive em busca das pistas que permitam elucidar o crime - a própria obra literária. Esta construção perpassa vários de seus textos críticos $^{78}$ : em Crítica y ficción, afirma que "[e]n más de un sentido el crítico es el investigador y el escritor es el criminal" (2001, p. 15); a frase que abre "Notas sobre literatura em um Diário", em Formas breves, é "Emma Zunz ou a narrativa como crime perfeito" (2000, p. 79); em El último lector, comenta-se que "[u]na de las mayores representaciones modernas de la figura del lector es la del detective privado (private eye) del género policial" (2005, p. 77).

A metáfora do leitor-detetive não é, de qualquer modo, uma invenção de Piglia e, evidentemente, não é uma exclusividade de seu repertório crítico, sendo quase um lugarcomum no estudo da literatura. Ao se definir o detetive como um decifrador, por exemplo,

\footnotetext{
${ }^{78}$ Como já o aponta, por exemplo, Susana González Sawczuk : "La lectura que desvela la búsqueda de marcas, señales, indicios, signos o síntomas encubiertos, se esconden detrás de la hipótesis de la estructura policial, recreada por Piglia, que envuelve al crítico y al escritor.” (2008, p. 24)
} 
pode-se citar o paradigma indiciário de Carlo Ginzburg ${ }^{79}$, citado também por Antoine Compagnon $^{80}$ ou Júlio Pimentel Pinto ${ }^{81}$. Ainda quando a metáfora não é explícita - o leitor pode ser identificado com o caçador e o adivinho e não com o detetive, propriamente, ao passo que este pode remeter a um observador arguto, mais que ao leitor especificamente -, a analogia continua válida ao se pensar que o detetive não só "lê" as pistas do crime, como também formula hipóteses para sua elucidação - como o adivinho - e deve "caçar" e prender o criminoso - como o caçador. Ao leitor, por sua vez, cabe observar com atenção e agudeza para - como o detetive - descobrir o que há por trás da aparência superficial do texto - ou do crime.

O gênero policial ressalta a metáfora do leitor-detetive, propondo muitas vezes ao leitor que, acompanhando os indícios revelados pela narração, faça também o papel do detetive formulando suas hipóteses para a resolução do crime e consequentemente para o desfecho da intriga narrada. Não obstante, é importante ressaltar também que, do ponto de vista da crítica literária - ao menos da crítica desenvolvida por Piglia e Compagnon, por exemplo -, a metáfora leitor-detetive pode ser aplicável à leitura de qualquer texto, não só à dos pertencentes ao gênero policial. Entende-se neste caso que a leitura é o deciframento dos signos que estão presentes em todo texto e podem ser mais ou menos implícitos e enigmáticos $^{82}$. Assim, o encontro do leitor-detetive com o gênero policial na obra de Piglia não é uma ocorrência que se poderia considerar de antemão previsível ou obrigatória. Dito de

\footnotetext{
${ }^{79}$ Ginzburg, em "Sinais: Raízes de um paradigma indiciário", afirma que: "O conhecedor de arte é comparável ao detetive que descobre o autor do crime (do quadro) baseado em indícios imperceptíveis para a maioria" (2011, p. 145); e ainda que o "caçador teria sido o primeiro a 'narrar uma história' porque era o único a capaz de ler, nas pistas mudas, (se não imperceptíveis) deixadas pela presa uma série de eventos” (p. 152)

${ }^{80}$ Compagnon, em seu $O$ demônio da teoria, diz que: "O indivíduo é um leitor solitário, um intérprete de signos, um caçador ou um adivinho [...]" (2010, p. 35).

${ }^{81}$ Ao analisar as histórias de Montalbano, detetive criado por Andrea Camilleri, Pinto fala "da velha imagem do detetive como um private eye, um olho contratado, preparado para enxergar aquilo que os outros não conseguem ver." (2004, p. 177)

${ }^{82}$ A ideia da leitura associada ao deciframento de signos e ao jogo ligado a este procedimento é bastante discutida por Barthes. Em $O$ rumor da língua, por exemplo, afirma que "admite-se que ler é decodificar: letras, palavras, sentidos, estruturas, e isso é incontestável; mas acumulando as decodificações, já que a leitura é, de direito, infinita, tirando a trava do sentido, pondo a leitura em roda livre (o que é sua vocação estrutural), o leitor é tomado por uma inversão dialética: finalmente, ele não decodifica, ele sobrecodifica; não decifra, produz, amontoa linguagens, deixa-se infinita e incansavelmente atravessar por elas: ele é essa travessia." (2004b, p. 41)
} 
outro modo, Piglia poderia cultivar a imagem da leitura como investigação em seus textos críticos sem que sua obra ficcional se voltasse para o gênero policial. Do mesmo modo o gênero policial não implica automaticamente uma adesão, em termos teóricos, à metáfora do leitor-detetive. Em entrevista dada a Guillermo Mayr (2009b), o próprio Piglia afirma:

Yo creo que el modelo del relato como investigación no supone ni exige que el investigador sea un policía o un detective, ni que esté investigando un crimen o un delito. El modelo de investigación puede servir para construir relatos donde la investigación tenga otra función; no hay que asimilar "investigación" con "resolución del crimen". Entonces, para mí, el género policial ha funcionado como una estrategia narrativa fundada, básicamente, en la idea del relato como investigación.

É uma visão da leitura como constructo do mundo ficcional e uma visão da construção do real como relato policial que levam as duas ideias a se mesclarem. Para Daniel Link, a “outra razão que torna interessante o policial é estrutural: o policial é um relato sobre o Crime e a Verdade. É nesse sentido que o policial é, além do mais, o modelo de funcionamento de todo relato [...]." (2002, p. 73) Dito isto, tomemos o caso de Plata quemada para tentar ver de que modo se dá essa relação entre o gênero e os pressupostos teóricos do autor expostos em seus textos críticos.

Em Plata quemada, Ricardo Piglia apropria-se de um gênero fortemente associado à literatura de massa, operando, no entanto, uma série de transgressões ao gênero que conferem ao romance outro semblante, mais original e desafiador. Ou, como afirma em suas próprias palavras o escritor na mencionada entrevista dada a Guillermo Mayr (2009b):

El género está presente en mi literatura sin que yo escriba directamente narrativa policial. Entonces, en "Respiración artificial" hay investigaciones múltiples, la forma del relato como investigación, digamos, que define un poco la forma de la novela, y en el caso de "Plata quemada" hay cierta relación con cierta tradición del género, digamos, la idea de la novela criminal, la novela contada desde la conciencia de los criminales más que la novela concebida como una investigación. El género funciona, para mí, como un punto de referencia, pero nunca he escrito textos del género en sentido estricto. 
Claro que, aqui, supõe-se que o "gênero em sentido estrito" de que fala Piglia remete ao gênero em seu sentido mais tradicional, ou, ao menos, a certo matiz prescritivo associado ao conceito. Ao renegar a escritura de textos de gênero, mas aceitá-los como "ponto de referência", o que Piglia realiza é uma transgressão que, ao mesmo tempo em que supera os limites do conceito, também o delimita e conforma, o que remete novamente à ideia de que a “transgressão concerne ao limite", presente no já mencionado no capítulo anterior "Prefacio a la transgresión" (1999) de Foucault.

A primeira transgressão diz respeito aos protagonistas da história: enquanto o policial clássico centra sua narrativa na figura do detetive - seja o detetive cerebral e passivo do romance de enigma, como o Auguste Dupin de Edgar Allan Poe ou o Sherlock Holmes de Arthur Conan Doyle; seja o detetive "durão" e pragmático do romance duro ou noir, como o Sam Spade de Dashiell Hammett ou o Philip Marlowe de Raymond Chandler -, Plata quemada tem como protagonistas os criminosos, notadamente o Nene Brignone e o Gaucho Dorda. O procedimento em si de centrar a narrativa no criminoso não é absolutamente novo: vejam-se, por exemplo, os protagonistas, às vezes também narradores, de romances como The Postman Always Rings Twice (1934), de James M. Cain ${ }^{83}$, They Shoot Horses, Don't They? (1935), de Horace McCoy ${ }^{84}$, The Killer Inside Me (1952), de Jim Thompson ${ }^{85}$, Black Friday (1954), de David Goodis ${ }^{86}$ ou The Talented Mr. Ripley (1955), de Patricia Highsmith ${ }^{87}$. A transgressão se dá, portanto, em relação ao modelo mais tradicional do policial, mas a configuração da dupla de personagens delinquentes de Plata quemada - o dandy portenho e o gaucho pampeano - representa uma originalidade em relação ao que se espera do estereótipo destes personagens ao mesmo tempo em que os insere em um ambiente literário também

\footnotetext{
${ }^{83}$ O destino bate a sua porta. (CAIN, 1998)

${ }^{84}$ Mas não se mata cavalo?(McCOY, 1982)

${ }^{85} \mathrm{O}$ assassino em mim. (THOMPSON, 2005)

${ }^{86}$ Sexta-feira negra. (GOODIS, 2007)

${ }^{87}$ O sol por testemunha. (HIGHSMITH, 1981)
} 
inesperado: o policial ${ }^{88}$. O Gaucho e o Nene são os transgressores dentro da trama e são as transgressões que tecem a trama, o que provoca o estranhamento do leitor que busca no romance o gênero e suas marcas mais reconhecíveis.

Por outro lado, a figura do narrador também se modifica: se no policial clássico costuma-se ver uma voz narrativa unívoca - a do amigo do detetive cerebral, a do narrador em terceira pessoa onisciente ou até a do criminoso em tom de confissão ou memória -, no romance de Piglia a narrativa nos chega por meio de narradores múltiplos, muitas vezes contraditórios, falhos e pouco confiáveis. Uma nova expectativa - a de certa unidade narrativa - daquele que busca, de um modo ou de outro, o gênero no romance é também transgredida.

A experiência de leitura que Plata quemada nos oferece passa a ser então ambígua: identificamos com certa facilidade muitos elementos do romance policial, especialmente de sua vertente norte-americana, dura, do romance noir, ao mesmo tempo em que nos é exigida uma superação de nosso horizonte de expectativa em relação a um romance policial. Tal procedimento configura a transgressão do gênero, seja este entendido como expectativa de leitura (o que esperamos encontrar em um romance policial), como expectativa do mercado editorial (o que se vende como romance policial dentro da literatura de massas), seja como marca de um gênero contemporâneo ao qual se inscreveria a obra (afinal a que gênero pertence Plata quemada, a que novo modelo nos levam suas transgressões?).

A resposta às últimas questões poderia nos levar novamente à zona de conforto do gênero, afinal a determinação de parâmetros que alinhassem Plata quemada a outros romances publicados na mesma época - ou mesmo a outras narrativas de Piglia - forneceria ao leitor um novo horizonte de expectativa, ao mercado um rótulo para vender sua produção editorial, à leitura crítica um novo arcabouço teórico para analisar esta e outras obras. O problema que se apresenta é que os mecanismos que corrompem o policial enquanto gênero

\footnotetext{
${ }^{88}$ De todo modo, ainda que não aplicada especificamente a personagens delinquentes de uma narrativa policial, a dualidade entre cosmopolitismo e criollismo é frequente e marcante na cultura argentina, sendo o ponto de partida, por exemplo, para a leitura que Beatriz Sarlo faz de Borges em Borges, un escritor en las orillas (1995).
} 
no romance e dificultam seu enquadramento em algum modelo junto a outros textos atuam também em outras leituras possíveis de Plata quemada: a do romance na linha do livroreportagem, na de uma tragédia argentina com referências aos modelos clássicos gregos, na da mescla contemporânea entre ficção e ensaio, etc. A leitura possível que resta, então, parece ser a que confere ao texto sua devida individualidade, em que dialogam leituras diversas, inclusive as importantes que remetem a tradições genéricas.

\title{
Reportagem e ficção
}

Entre os diálogos que se estabelecem entre leituras propostos em Plata quemada, pode-se abordar a discussão sobre a relação entre o gênero policial e o jornalismo. Retomando o artigo "Sobre el género policial”, publicado em Crítica y ficción, lê-se (2001a, p. 60-1):

\begin{abstract}
Auden decía que el género policial había venido a compensar las deficiencias del género narrativo no ficcional (la noticia policial) que fundaba el conocimiento de la realidad en la pura narración de los hechos. Me parece una idea muy buena. Porque en un sentido Poe está en los dos lados: se separa de los hechos reales como el álgebra pura de la forma analítica y abre paso a la narración como reconstrucción y deducción, que construye la trama sobre las huellas vacías de lo real. La pura ficción, digamos, que trabaja la realidad como huella, como rastro, la sinécdoque criminal. Pero también abre paso a la línea de la non-fiction, la novela tipo $A$ sangre fría de Capote.
\end{abstract}

Pode parecer que esta é uma concepção do gênero policial à qual Plata quemada se adéqua perfeitamente, com sua narrativa fragmentada, buscando-se erguer entre os "vazios" da realidade desta história supostamente real. Sua narrativa, entretanto, não resulta em um texto policial, à maneira de Poe - ou de outras importantes figuras do gênero -, nem se adéqua à non-fiction de Capote.

Na narrativa policial mais tradicional, a partir de Poe, é importante que "todas as peças se encaixem" no final. O relato jornalístico aparece para o detetive nesta narrativa como uma 
primeira fonte - incompleta - dos fatos, fornece a ele eventualmente informações erradas ou até as manipula, fato do qual o detetive se dá conta em determinado momento. De qualquer modo, uma realidade unívoca e mais ou menos completa e coerente se impõe e a narrativa ficcional dará conta de conferir esta uniformidade e clareza no final. Assim, enquanto a notícia de jornal procura - em tese - narrar objetivamente a partir de uma observação da realidade, e nisto busca fornecer sempre um sentido ao narrado que não dê margens a muita interpretação ou subjetividades, a ficção pode reconstruir e deduzir uma realidade com um sentido aparente mais fechado preenchendo as lacunas e usando como ingrediente a incompletude e as ambiguidades dessa mesma realidade. Em Plata quemada, contudo, o gênero não se realiza nesta complementação: o romance não dá um sentido à realidade dos fatos supostamente reais e a narrativa - com as notícias incluídas nela - não preenche lacunas. O relato jornalístico, mostrando toda sua "deficiência" em narrar a realidade só a partir dos fatos, serve aqui como forma de construção de uma narrativa em que múltiplos discursos parecem menos destinados a dar uma leitura da realidade e mais a configurar, cada um a seu modo, uma ficção própria.

Em resumo, os jornais em Plata quemada não assumem nenhuma das funções tradicionais que costumam ter no gênero policial: não são a fonte incompleta da verdade complementada pelo detetive - pois não se completam nunca -; não são a fonte duvidosa ou equivocada que o detetive vai corrigir - pois as dúvidas não se dissipam e os equívocos não se esclarecem -; e tampouco são a manipulação a ser explicitada com a qual lida o detetive e o leitor - pois esta nunca é desmascarada. O discurso dos jornais no romance, que parecem em um primeiro momento ter um papel importante na suposta tentativa de cobrir as "falhas" da narrativa, acaba tendo um papel que se explicita como ironia ou como jogo com o leitor. Por isto, contradiz-se a tese de que o gênero policial vem a cobrir uma falha da notícia policial, que nunca poderá dar conta da verdade em sua completude, pois a narrativa de Plata 
quemada, se lida como estritamente pertencente ao gênero policial, é igualmente falha como complemento da verdade, ainda que, de fato, crie um discurso em que a verdade é múltipla e ambígua. Dentro desta lógica em que o uso do relato jornalístico transgride as convenções do gênero, as abundantes expressões como "segundo os jornais" e "disseram os jornais", que, supostamente, cobririam lapsos da narrativa - aquilo que o narrador não tem condições de narrar -, só reforçam, ao fim, a percepção de uma narrativa incompleta e entrecortada.

As lacunas das narrativas jornalísticas apresentadas no romance - e das várias que se construíram sobre o caso real - são muitas: quais eram as conexões políticas do bando, qual o real interesse da polícia no seu extermínio, qual a verdadeira quantia de dinheiro roubada e qual seu paradeiro ${ }^{89}$, etc. O desconhecido destino de Malito - "la gran incógnita (el momento fantástico) del libro" (PQ, 246) - não é, ao contrário do que sustenta o narrador, um mistério especialmente intrigante ou o "momento fantástico" do romance, mas sim uma das muitas lacunas no enredo da história. O que o narrador faz aqui é jogar com a expectativa do leitor de policial, que espera a narrativa tradicional do gênero em que todos os detalhes são elucidados e nada fica sem explicação. A ironia do narrador está em atribuir a este fato uma importância fundamental, relegando muitas outras questões à irrelevância. Além disso, a própria narrativa se mostra se mostra falha em detalhes, estes sim sem grande importância, mas fáceis de serem elucidados ou superados pela narrativa ficcional. Exemplos disto são as contradições ou “descuidos”, intencionais ou não, na descrição de Giselle - “de largo pelo negro” (PQ, p. 100) ou com "el pelo corto y duro" (PQ, p. 116)? - ou do policial uruguaio Washignton Santana Cabris de León - que, aparentemente, morre duas vezes (PQ, p. 164-5 e 187).

O que pode ser tomado como "falhas" ou mera ironia da narração, contudo, pode ser lido de maneira mais complexa. As muitas referências ao montante do dinheiro roubado, por

\footnotetext{
${ }^{89}$ Ainda que no romance o dinheiro tenha sido queimado, de acordo com a crônica jornalística da época e reportagens posteriores (ver COBAS, 2000; HABERKORN, 1998; JUMA, 2004a, 2004b, e 2004c) isto não aconteceu no episódio em que se baseia Plata quemada. Depois do fim do cerco, nenhum dinheiro e somente uma pistola foi encontrada no apartamento destruído, segundo os policiais que primeiro invadiram o local ainda que isto pareça enormemente inverossímil.
} 
exemplo, são contraditórias ${ }^{90}$ e a ficção não cobre, como em outros casos, a "falha" de informação da notícia policial. Entretanto, as referências ao dinheiro assumem outro papel na narrativa que não o de cobrir as lacunas das fontes jornalísticas, já que importa pouco, no fim, saber quanto dinheiro se rouba e quem fica com ele, mas como o dinheiro se constitui como valor na sociedade e que discursos ele gera ${ }^{91}$. A falta de esclarecimentos sobre a questão, justificada por um suposto escrúpulo do narrador no Epílogo - “[...] cuando no he podido comprobar los hechos en fuentes directas he preferido omitir los acontecimientos." (PQ, p. 246) -, não encobre, assim, como a temática do dinheiro é trabalhada no romance ${ }^{92}$, por exemplo, com suas ressonâncias em referências a Arlt, como já foi visto.

Este papel do dinheiro como gerador de discursos na narrativa aparece, então, quando Nene reflete sobre o fato dos jornalistas abordarem o cerco ao apartamento como uma “complicada operação de resgate” - “¿De rescate de quién?’ había pensado el Nene” (PQ, p. 161). Também está presente na fala de Dorda - "Quemar dinero es feo, es pecado.” (PQ, p. 189) -, na ideia das pessoas de que "la plata quemada era un ejemplo de locura asesina" (PQ, p. 192, grifo meu) e no discurso do jornalista Jorge Foister - "Quemar dinero inocente es un acto de canibalismo.” (PQ, p. 191). Além disso, explicita-se como nem todos os discursos sobre o dinheiro são aceitos: enquanto a ideia capitalista do "dinheiro inocente" prospera entre a população indignada no romance, discursos críticos, ainda que moderadamente, sobre sua divinação na sociedade moderna são abafados. Aqui, mais uma vez, uma afirmação do

\footnotetext{
${ }^{90} \mathrm{O}$ narrador fala primeiro em "casi seiscientos mil dólares" (PQ, p. 17, quase 106 milhões de pesos em setembro de 1965, segundo o site do Banco Central Argentino - http://www.bcra.gov.ar/ (US\$1,00 / 176,30 pesos). Depois se fala em "más de medio palo en juego" (PQ, p. 20). Depois, "hay por lo menos cinco millones. [...] Sólo quería la mitad de la mitad, es decir, quería limpio setenta y cinco mil dólares (según sus cálculos)" (Nino Nocito, PQ, p. 23-4); “- Por lo bajo - le había dicho su tío - es un millón de mangos por cabeza." (Fontán Reyes, PQ, p. 25); "7.203.960 pesos" (US\$ 40.862, conta o tesoureiro Martínez Tobar, PQ, p. 32); "[los bandidos en el apartamento decían tener] tres millones de pesos" o "medio palo verde" (PQ, p. 154; 161). Por fim, novamente o narrador: "Luego de un momento se supo que los delincuentes estaban quemando cinco millones de pesos que le quedaban del atraco a la Municipalidad de San Fernando, de donde, como es sabido, se llevaron siete millones." (PQ, p. 190). Fazendo as contas, vê-se que estas referências, confrontadas, não batem entre si.

${ }^{91}$ O próprio Nene afirma, em meio ao cerco: "No es por plata" (PQ, p. 186).

${ }^{92}$ Ver, por exemplo, o artigo "Cómo habla la plata" de Michelle Clayton (PÉRSICO, 2004, p. 135-44).
} 
narrador - a de que o dinheiro seria "un signo que sirve según el uso que cada uno le quiera dar” (PQ, p. 192) - não se reflete no comportamento de todos os personagens, já que, se a analogia feita pela imprensa do dinheiro queimado com um "aquelarre del medioevo" (PQ, p. 190) parece não suscitar grandes comoções, o mesmo não acontece com a declaração do filósofo Washington Andrada à revista Marcha de que (PQ, p. 192-3):

[...] consideraba ese acto terrible, una especie de inocente potlach realizado en una sociedad que ha olvidado ese rito, un acto absoluto y gratuito en sí, un gesto de puro gasto y de puro derroche que en otras sociedades ha sido considerado un sacrificio que se ofrece a los dioses porque sólo lo más valioso merece ser sacrificado y no hay nada más valioso entre nosotros que el dinero $[\ldots]$

Enquanto a humanização do dinheiro é vista com naturalidade - sua destruição causa mais comoção que as muitas mortes produzidas pelos bandidos -, a simples constatação de que o dinheiro é divinizado e pode passar à esfera do mito, com os rituais relacionados a ele, rende a Andrada uma intimação de um juiz - curiosamente, supõe-se, que sob a acusação de ter proferido alguma blasfêmia. Ou seja, o dinheiro mostra-se como um signo que serve a alguns usos que lhe são atribuídos e aceitos socialmente, enquanto outros usos para esse mesmo signo são censurados.

A partir desses exemplos, é possível ver, então, como a relação entre os relatos jornalísticos e a narrativa policial se deturpa com relação aos cânones do gênero, pois aqueles não servem como complementação a esta - já que nada "se completa" ao fim. Ao mesmo tempo, tais relatos, ainda que supostamente reias, não serviriam a uma narrativa do gênero non-fiction, já que, pela análise que se faz aqui, se desmantela a ideia do romance como reconstituição histórica e se reforça sua construção como uma sobreposição de discursos que competem entre si, se antagonizam e, eventualmente, até se complementam. Ou seja, aqui, nem o gênero policial resolve os crimes das páginas policiais dos jornais, nem o discurso jornalístico confere "verdade" e "certeza” à ficção literária. Assim, Plata quemada escapa das 
definições mais rígidas do policial - com o crime descoberto no final, o criminoso geralmente punido e um tom apaziguador - e tampouco se coloca lado a lado a obras como A sangue frio, de Capote - que apelam ao tom documental e de reconstituição, ainda que permeado por um estilo e uma visão da realidade mais pessoais.

\section{A tragédia argentina}

Enquanto o policial e o livro reportagem são gêneros relativamente modernos com os quais Plata quemada pode se relacionar a partir de cânones mais restritos, o conceito de tragédia extrapola mesmo a noção de gênero formatada desde pelo menos a Poética de Aristóteles e passa a formar parte de uma ampla reflexão filosófica e estética que continua até os dias de hoje ${ }^{93}$. Como o romance é escrito e publicado no fim do século XX e a história se passa na década de 60 do mesmo século, é de se esperar que se busquem nele referências à "tragédia do homem comum", de Miller, ou, especialmente, ao "teatro dialético" de Brecht, que, de fato, são marcantes no texto. Entretanto, é a partir de elementos como o personagem Emilio Renzi e o narrador primário do romance, entre outras instâncias narrativas, que se pode ver um diálogo mais amplo e uma reflexão sobre o gênero que, como nos outros casos já analisados, não se resume a confirmar cânones e propostas teóricas prévias, mas sim conformar um discurso novo que se realiza na própria forma do romance.

Em uma conferência proferida em 2001 e publicada na revista brasileira Serrote com o nome de "Teoria do complô", Piglia afirma que (2009, p. 99-100):

No gênero romance, o complô substituiu a noção trágica de destino: certas forças ocultas definem o mundo social e o sujeito é instrumento dessas forças que não compreende. $\mathrm{O}$ romance introduziu a política na ficção sob a

\footnotetext{
93 Ver, por exemplo, Ensaio sobre o trágico, de Peter Szondi (2004), que discute a filosofia do trágico em filósofos como Schelling, Hegel, Schopenhauer, Nitzsche e Scheller e analisa a tragicidade em obras de Sófocles, Calderón de La Barca, Shakespeare, Racine e Büchner, entre outros.
} 
forma do complô. A diferença entre tragédia e romance parece estar ligada a um deslocamento da noção de fatalidade: o destino é vivido sob a forma de complô. Os oráculos mudaram de lugar; a trama múltipla da informação, as versões e contraversões da vida pública, eis o lugar visível e denso onde o sujeito lê cotidianamente a cifra de um destino que não chega a compreender.

A evidente influência das ideias brechtianas em Piglia, que transparecem no trecho acima, não eclipsam, de qualquer forma, uma presença das ideias clássicas aristotélicas, seja pelo uso de certo vocabulário, seja pela forma como se constroem alguns discursos dentro do romance. O narrador do Epílogo em Plata quemada, por exemplo, apresenta a história da crônica policial narrada como tendo adquirido para ele "la luz y el pathos de una leyenda" (PQ, p. 245, grifo do autor) e afirma em seguida, sobre o encontro com Blanca Galeano que lhe inspirou a narrativa, que: “[...] la escuché como si me encontrara frente a una versión argentina de una tragedia griega. Los héroes deciden enfrentar lo imposible y resistir, y eligen la muerte como destino" (PQ, p. 250). Antes, também o narrador descreve as ações e pensamentos do Gaucho Dorda apelando a um repertório afim às fontes da tragédia clássica: "Hay que salir, oye el Gaucho, como un oráculo, oye las órdenes, el Gaucho Dorda, un coro que le habla, las voces apagadas, que casi no se oyen [...]” (PQ, p. 203, grifos meus).

Já Renzi, o personagem que concebe o mundo através da literatura, constrói sua crônica dos fatos - e seu discurso dentro do romance - também calcada em uma visão clássica de literatura e tragédia:

"Hybris", buscó en el diccionario el chico que hacía policiales en El Mundo: "la arrogancia de quien desafía a los dioses y busca su propia ruina." (PQ, p. 91)

De todos modos el destino había empezado a armar su trama, a tejer su intriga, a anudar en un punto (y esto lo escribió el chico que hacía policiales en $E l$ Mundo) los hilos sueltos de aquello que los antiguos griegos han llamado el muthos. (PQ, p. 106, grifo do autor) 
La larga odisea que ya dura cuatro horas en el momento de escribir esta crónica [...] (PQ, p. 171)

La esencia táctica de la banda de Malito, su brillo trágico (escribiría más tarde Renzi en su crónica de los hechos para la página policial del diario $E l$ Mundo) [...] (PQ, p. 188)

Assim, a crônica que escreve Renzi sobre o cerco aos bandidos em Montevidéu se reveste de um discurso trágico que passa a ser mais uma das instâncias narrativas do romance, problematizando o gênero com uma adaptação a um momento histórico específico e refletindo uma visão de sociedade por certo muito diferente da grega na Antiguidade. Por outro lado, cria-se uma conexão com o conceito de teatro épico e o desenvolvimento das ideias de destino como complô e da ficção paranoica.

A consciência do destino inescapável aparece tanto na voz do narrador ${ }^{94}$ como na dos personagens. Os bandidos oscilam entre uma aceitação deste destino, como parece ser o caso de Nene ${ }^{95}$, e um questionamento desta postura passiva, caso do Cuervo Merelles ${ }^{96}$. Em todo caso, como aponta Piglia em "Teoria do complô", esse destino aparece para todos na forma do complô, que substitui a noção trágica de destino, desencadeada pelo erro (hamartía), e gera a paranoia $^{97}$ que muitas vezes move os personagens. Por isso, Malito acreditava que todos os telefones da cidade estavam grampeados (PQ, p. 18) e que, por mais que planejassem ou lutassem, sua luta tendia, sempre, a ser inglória, já que "la suerte es más importante que el coraje, más importante que la inteligencia y las medidas de seguridad. El azar, paradójicamente, está siempre del lado del orden establecido.” (PQ, p. 58) A noção do

\footnotetext{
94 "En el fondo, lo que se teme más secretamente siempre ocurre [...]" (PQ, p. 150)

${ }^{95}$ Para Brignone, "Si algo te tiene que pasar, va a pasar igual aunque no haya nadie." (PQ, p. 12) e "Los que viven bajo presión, en situación de extremo peligro, perseguidos, acosados, saben que el azar es más importante que el coraje para sobrevivir en un combate." (PQ, p. 98)

${ }_{96}$ Como quando conversa com Nene sobre tentar fugir do apartamento ou esperar a chegada de Malito: "Entonces para vos hay que dejar todo en manos de la suerte... [...] Me parece mal negocio.” (PQ, p. 147)

97 "No hay nada peor que el día antes, $[\ldots]$ porque uno se pone vidente, ve visiones, cualquier cosa parece una señal de mala suerte [...]" (PQ, p. 17)
} 
complô, que para Malito emana da ordem estabelecida, é vivida também - e também paradoxalmente - pelo outro lado da guerra, o Comissário Silva (PQ, p. 66-7):

Su hipótesis era que todos los crímenes tenían un signo político. [...] Era un paranoico, no dormía nunca, tenía una serie de ideas extravagantes sobre el futuro político y el avance de los comunistas y los de los grasas. Y bajaba línea, todo el tiempo hacía discursos, explicaba.

Então, como na antiga Grécia os desígnios divinos se faziam válidos para todos, na concepção trágica de Plata quemada a ficção paranoica se constrói pelo discurso de todos que conformam a narrativa do romance, que, por sua vez, busca encontrar eco nos discursos sociais veiculados na Argentina especialmente, mas não só, nos anos 1960. De qualquer maneira, o conceito clássico da tragédia como gênero literário se faz presente no diálogo com a forma moderna desenvolvida por Piglia, o que pode ser observado, mais uma vez, no personagem do Gaucho Dorda.

Nesta espécie de epopeia trágica do Prata é Renzi quem, especialmente, introduz conceitos aristotélicos como hybris e muthos, mas é Dorda quem parece encarnar mais do que qualquer outro personagem a figura deste moderno anti-herói trágico do romance que se vê envolto em uma paranoica trama de complô, cujos sinais agourentos estão por toda parte: “estaba siempre viendo signos negativos y tenía múltiples cábalas que le complicaban la vida." (p. 12). Seus “oráculos" se travestem nas instituições sociais: a polícia ${ }^{98}$, a quem combate como quem combate o destino; a lei ${ }^{99}$, que não o entende e o persegue desde sempre; a imprensa ${ }^{100}$, corrupta e sensacionalista; a medicina moderna, na figura sinistra do Dr. Bunge, o médico psiquiatra ${ }^{101}$; a família, encarnada na incompreensão de sua mãe ${ }^{102}$.

\footnotetext{
98 "Lo había matado [al policía] porque odiaba a la policía más que nada en el mundo y pensaba de un modo irracional que cada policía que él mataba no iba a ser reemplazado.” (PQ, p. 40)

99 "Lo detuvieron varias veces de chico hasta que a los quince lo mandaron al neuropsiquiátrico de Melchor Romero, cerca de La Plata." (PQ, p. 73) No hospital, Dorda é estuprado por três enfermeiros.

100 “- Te matan igual, huevón [...] son todos botones los periodistas...” (PQ, p. 184)

101 “- Si sigue así va a terminar mal, Dorda - le dijo el médico.
} 
Assim, em um contexto moderno, mais do que se criar uma tragédia do homem comum - ou, mais especificamente, a tragédia do marginalizado -, expõe-se uma narrativa em que a tragédia original assume novos signos. O próprio narrador do Epílogo percebe o páthos gerado pela história que, através de peripécias complexas ${ }^{103}$, conduz a uma katársis representada pela queima do dinheiro, da qual, a propósito, não se tem notícia nos relatos sobre os fatos que deram origem ao romance. Evidencia-se também ao final a hamartía - o erro trágico - de Dorda representada pela morte da Rusita, a pobre prostituta exilada que "pedia” que lhe dessem fim a uma vida miserável, que é o início de sua trajetória trágica. Por fim, há também uma espécie de anagnórisis no reconhecimento da irreversibilidade de seu destino - "Listo para morir no; porque nadie está listo nunca para morir, pero sí dispuesto a morir, como quien lleva un estigma de chico, desde siempre [...] (PQ, p. 219-20)”.

Por outro lado, são evidentes também os elementos antiaristotélicos de Plata quemada, a começar pelo caráter obviamente não elevado dos personagens. Esta diferença fundamental evidencia não uma impossibilidade de tragédia moderna e marginal, mas sim a natureza diversa da sociedade contemporânea, geradora de outro sentido trágico para o arcabouço artístico concebido pelos clássicos. Por isso, o coro do romance, que pode ser representado pelas pessoas presentes ao cerco ao apartamento em Montevidéu, adquire aqui outra função, ainda que represente também um papel, como um dos personagens, tal qual no modelo clássico. Mais do que servir a um esclarecimento da trama - impossível a partir dos atos e falas dos outros personagens -, o povo replica, tal qual a mídia, os valores dominantes da sociedade, para os quais o grupo de marginais é incompreensível e intolerável. O erro

\footnotetext{
- Yo voy mal - dificultoso para expresarse, el Gaucho Rubio -. Vengo mal desde chico. Yo soy desgraciado. No sé expresarme, doctor." (PQ, p. 225)

"Siempre había sido objeto de interés de los médicos, los psiquiatras. El criminal nato, el hombre que se ha desgraciado de chico, muere en su ley. Era un destino al que no podía escapar y al que era conducido [...]" (PQ, p. 234)

102 "Los dichos de la finada le vuelven como un rezo.

- Vos vas a terminar mal. (PQ, p. 220)

${ }^{103}$ Que vão do nó principiado pelo roubo ao desenlace desencadeado por Lucía Passero (PQ, p. 119-21), que, impulsionada por sua "tentación del mal", conduz Dorda, Brignone e Merelles ao fim inevitável.
} 
seria, entretanto, assumir o discurso - presente, entre outros, no romance - em que estes valores reverberados pelo povo/coro se equivaleriam aos ideais nobres do herói antigo, de onde derivaria o caráter baixo dos protagonistas, incapazes de protagonizar uma tragédia, portanto. A diferença fundamental não está em quem representa os papéis elevados e trágicos, mas em como uma sociedade contemporânea gera discursos trágicos calcados em outra realidade diferente da original clássica.

Em uma sociedade capitalista moderna, o ideal nobre do herói antigo desaparece e seu substituto é um instinto de sobrevivência que ela mesma impõe ${ }^{104}$. Por isso, não se pode pensar todo o cerco ao apartamento e sua sangrenta conclusão como uma ação suicida ou unicamente impulsionada pelo delírio das drogas, já que há uma esperança de salvação paradoxalmente coexistindo com a consciência do destino fatal ${ }^{105}$. As drogas, a propósito, não carregam, para os criminosos, um signo negativo de autodestruição ou fuga, mas um positivo, no sentido de dar algum propósito e um objetivo a sua jornada nesta sociedade capitalista: "La plata es como la droga, lo fundamental es tenerla." (PQ, p. 44, grifo do autor) Para Dorda, mais até do que o dinheiro, era a droga que importava ${ }^{106}$ e se mostrava como a única que calava suas vozes interiores ${ }^{107}$. Toda a condição de marginalizados da sociedade - ladrões, assassinos, pobres, drogaditos, homossexuais -, que se manifestava na mente esquizofrênica de Dorda e ressoava também na mídia, nas televisões e rádios que cobriam ao vivo o cerco, acaba impulsionando estes personagens a viver uma vida paralela, que inclui o submundo criminal, a subversão política, o delírio dos narcóticos. O que para o status quo era uma

\footnotetext{
104 "La maldad - decía Dorda, muy acelerado con la mezcla de la anfeta y la coca - no es algo que se haga con la voluntad, es una luz que viene y te lleva.” (PQ, p. 73)

${ }^{105}$ São vários os momentos, durante o cerco, em que se menciona a esperança de seus cúmplices de que Malito possa vir resgatá-los. (PQ, p. 146-7; 151; 156; 169; 182; 205)

106 "La plata y las decisiones significaban poco para él. Su interés exclusivo eran las drogas [...]” (PQ, p. 69)

107 " [...] se da un pico de cocaína en la vena del brazo derecho. Lo hace porque está oyendo lejos, voces, ahora, voces suaves, de mujer, y no las quiere oír [...]" (PQ, p. 151-2)
} 
exceção à única forma de existência social aceitável ${ }^{108}$, para eles era a única forma de sobrevivência possível.

A impossibilidade de perspectiva trágica na história dos criminosos vem de uma porção dominante - ainda que não necessariamente majoritária - da sociedade que produz também um discurso dominante e totalitário. Aderindo-se somente a este discurso no romance - "Es una historia larga, en fin, y complicada, que pasa por todos los recovecos oscuros de la vida nocturna [...]. Será pues la policía quien lo diga.” (PQ, p. 136, grifo meu) - a leitura da tragédia no texto só poderá existir, no máximo, de modo irônico. Todavia, tampouco são os discursos confusos e só até certo ponto autoconscientes dos marginalizados que oferecem outra perspectiva. Outro personagem, que "ouve vozes" como Dorda, também parece captar, ainda que confusamente, a multiplicidade de discursos que se entrecruzam na sociedade e na trama de Plata quemada: o radiotelegrafista Roque Pérez, que (PQ, p. 206-7):

[...] estaba conectado con el espíritu de toda la ciudad. Las voces entraban por los canales interiores porque en la telaraña del portero eléctrico la policía había plantado los micrófonos (¿o era uno solo? ¿un solo micrófono en el aire?) [...] [Q]uizás lo habían puesto ahí, a él, Pérez, en turnos de diez horas, porque había un secreto que los porteños escondían y que los jefes trataban de averiguar antes de matarlos. Pero las voces también llegaban desde otro lado que no puede detectar. Desde el pasado, pensó el radiotelegrafista. Quizás desde las cañerías subterráneas navegaban las palabras de los muertos $[\ldots]$

O que Pérez capta e a narrativa retransmite ao leitor não é só a voz dos bandidos, é o espírito da cidade, as vozes dos mortos e do passado. Tentando identificá-las, o radiotelegrafista, entretanto, jamais as julga. Se é possível a leitura trágica da trama, ela talvez tenha a ver com a leitura das vozes que faz Roque Pérez: "No quería captar el sentido, sino el sonido, la diferencia de las voces, los tonos, la respiración, para identificar a cada uno." (PQ, p. 182)

108 "Se sabe que esta clase de delincuentes (señaló el médico policial que controla el puesto policial instalado en el lugar) [...] es adicta a las drogas, a fin de mantenerse en condiciones para soportar situaciones como las vividas en esta oportunidad." (PQ, p. 155) 


\section{Crítica e ficção: hibridismo}

Assim como a narrativa jornalística corrompe a policial e é, em tese, corrompida por ela, na teoria ficcional de Piglia, também a tragédia, um gênero clássico por excelência, encontra uma contrapartida nas ideias críticas do autor sobre a narrativa contemporânea - a ficção paranoica, a teoria do complô - e uma realização ficcional em algum nível de Plata quemada. Em artigo publicado em Crítica y ficción, "La lectura de la ficción", reprodução de entrevista de 1984 a Mónica López Ocón, Piglia afirma (2001a, p. 15-6):

Por mi parte, me interesan mucho los elementos narrativos que hay en la crítica: la crítica como forma de relato; a menudo veo la crítica como variante del género policial. [...] Se podría pensar que la novela policial es la gran forma ficcional de la crítica literaria. [...] Me interesa mucho la estructura del relato como investigación: de hecho es la forma que he utilizado en Respiración artificial. Hay como una investigación exasperada que funciona en todos los planos del texto.

Já o escritor e crítico mexicano Jorge Volpi, em Mentiras contagiosas (2008), discorrendo sobre os gêneros, as mesclas e o hibridismo literário na narrativa contemporânea, assume uma postura cuidadosa quanto ao uso do policial e outros gêneros populares, potencialmente interessantes para o desenvolvimento de uma literatura autoral ao mesmo tempo em que perigosos por seu caráter totalizante e homogeneizante (p. 35-6):

En un principio, la utilización de los recursos de las novelas de género significó una bocanada de aire fresco frente a la experimentación formal de los años sesenta, pero su uso indiscriminado se ha convertido en una carga. En vez de arriesgarse a explorar nuevas sendas, numerosos autores, auspiciados por sus editores, se conforman en seguir esquemas preestablecidos que les garantizan grandes tirajes y fama inmediata. No nos hallamos en una época de decadencia de la novela, sino en el manierismo de lo policíaco, lo negro, lo fantástico y lo folletinesco. 
Por outro lado, Volpi enxerga com bons olhos a simbiose entre romance em ensaio na obra de escritores como Sergio Pitol, Javier Marías e Enrique Vila-Matas, aos quais se poderia acrescentar o nome de Piglia (2008, p. 36):

Todos ellos han experimentado distintas variedades de esta mutación, a veces por medio de largos pasajes ensayísticos en el interior de sus novelas, a veces con ensayos narrativos o verdaderos híbridos. [...] Acaso la unión de la ficción con el ensayo represente el mejor camino que le queda por explorar a la novela en nuestros días.

Assim, em um romance como Respiración artificial também é evidente a discussão crítica levada a cabo, sobretudo na segunda parte do romance, cheia de passagens ensaísticas. Além disso, se como o próprio Piglia afirma, no artigo "La lectura de la ficción", que "la crítica es una de las formas modernas de la autobiografía” (2001a, p. 13), há muito de narrativa em sua obra crítica como já notou Gabriela Speranza em seu artigo "Autobiografía, crítica y ficción: Juan José Saer y Ricardo Piglia” (2001). A questão é se o mesmo se poderia dizer de Plata quemada, romance que, ao menos na aparência mais superficial, entrega-se à trama pura e simples ou, eventualmente, a algum aprofundamento psicológico de um dos personagens, sem, no entanto, jamais ter passagens propriamente ensaísticas, tais como as que notamos claramente em Respiração artificial.

De fato, Plata quemada não parece realizar o hibridismo entre romance e ensaio presentes em Trilogía de la memoria (1996-2005), de Pitol, Corazón tan blanco (1992), de Marías ou Historia abreviada de la literatura portátil (1985), de Vila-Matas. Tampouco é uma narrativa na qual discussões literárias surgem da boca dos personagens ou das situações da trama em si, como em Respiración artificial (1980), Los detectives salvajes (1998), de Bolaño, ou mesmo O nome da rosa (1980), de Umberto Eco. No entanto, como aponta Daniel Link em "O jogo dos cautos (sobre o policial)" (2002, p. 72): 
Falar do gênero policial é, portanto, falar de bem mais que literatura: de imediato, de filmes e de séries de TV, de crônicas policiais, de noticiários e de histórias em quadrinhos: o policial é uma categoria que atravessa todos os gêneros. Porém também é falar do Estado e de sua relação com o crime, da verdade e de seus regimes de aparição, da política e de sua relação com a moral, da Lei e seus regimes de coação.

Plata quemada transgride o gênero policial realizando um hibridismo entre o romance policial e outros gêneros. O relato jornalístico e certos tópicos da tragédia clássica são os campos pelos quais, em especial, a narrativa parece passar nessa operação de transgressão travessia, ida além das fronteiras estabelecidas. Os procedimentos narrativos da construção da novela, seus personagens e as inúmeras citações - diretas e indiretas; literárias, políticas e históricas -, tão marcantes na escrita de Piglia, oferecem ao leitor crítico, insistente, indagador, novos questionamentos que conduzem a novas travessias e novas leituras híbridas: será o romance, eminentemente, sobre o papel do dinheiro na sociedade e, neste sentido, há algo de análise sociológica no texto? Será a trama principal de roubo, fuga e violência pano de fundo alegórico para o momento histórico vivido pela Argentina às portas das terríveis ditaduras dos anos setenta? Ou para o apogeu das políticas neoliberais na América Latina nos anos noventa? Será o personagem do Gaúcho Rubio um ponto de diálogo com a tradição gauchesca, não do ponto de vista estético formal, claro, mas no sentido de discutir uma enorme - e polêmica - tradição cultural argentina, que de Sarmiento passa por Hernández, por Güiraldes, por Borges, por todos de alguma maneira?

Podem-se considerar todas estas perguntas válidas, mesmo que as respostas dadas após a reflexão as rejeite, mas há ainda outra transgressão possível do romance: a que remete Plata quemada à obra do próprio autor, tanto suas outras narrativas, como suas ideias críticas, expressas em artigos, ensaios, conferências e entrevistas. No artigo “De 'Pulp Fiction' a metaficción literaria: las transformaciones del personaje detectivesco en la narrativa policial brasileña”, Michele Dávila Gonçalves já aponta, ao falar sobre o gênero policial no Brasil que (2005, p. 85): 
en estas obras se requiere más esfuerzo del lector para seguir la historia y por ende, las pistas para resolver el enigma. Esto se debe a que las novelas policiales más recientes tienen en común una preocupación teórica con el género policíaco en sí y la literatura en general. Son textos llenos de alusiones, intertextualidad y erudición que los ejemplos clásicos del género no tienen. Las obras son metaficciones donde los autores proponen y discuten teorías sobre el arte de escribir y en especial la narrativa policial.

A metaficção vista por Gonçalves nos romances policiais brasileiros exige, como ela mesma afirma, "mais esforço do leitor". Por outro lado, me parece que as alusões, intertextualidades e erudição muitas vezes são relativamente claras em muitos exemplos do policial contemporâneo - seja ele brasileiro, hispano-americano, norte-americano ou europeu. A dificuldade que pode encontrar o leitor está em seguir as pistas, em interpretá-las, não necessariamente em encontrá-las no texto.

Com relação às ideias de Gonçalves, é possível aprofundar duas questões que parecem ser fundamentais na leitura de Plata quemada. Em primeiro lugar, ainda que tome como ponto de partida o gênero policial, o diálogo intertextual proposto por Piglia não se centra propriamente na discussão do gênero em si. Claro que, ao transgredi-lo, comete um ato que, como diz Foucault, concerne ao limite. A narrativa ajuda a desestabilizar o gênero ao desestabilizar seus limites e este ato é, de todo modo, uma discussão teórica sobre a escrita e a literatura em geral. Há, no entanto, um diálogo teórico mais central com a própria visão de literatura que nos apresenta Piglia em seus textos críticos e ficcionais, com teses como a ficção paranoica e a teoria do complô; como a forma do relato como investigação; como a do dinheiro como motor social, a modo do que ele analisa na obra de Roberto Arlt; como a da violência e opressão do Estado como criadoras de narrativas, de ficções sociais. Por este caminho, Plata quemada aprofunda mais do que tudo uma leitura da visão pigliana da literatura, dos seus temas recorrentes, suas obsessões, seus questionamentos. 
Em segundo lugar, está a maneira como se constrói a narrativa mesma. Não se discute literatura praticamente em nenhum momento do texto do romance, ao mesmo tempo em que o texto é em si a realização de muitas das discussões de Piglia ao longo dos anos sobre o que é hoje a literatura, a cultura, a sociedade, a política e a história. As referências, alusões e citações não se esgotam na erudição por si só - demonstrada pelo escritor e exigida do leitor. A leitura proposta aqui exige, talvez, ainda mais esforço do leitor ao forçá-lo a fazer parte do diálogo com Piglia sobre a literatura em seus termos, nos termos que ele propõe. Ao depararse com as pistas do texto, com os indícios do crime - real ou literário -, o leitor não encontra propriamente respostas, não decifra nada. A tarefa é descobrir o jogo escondido que desvelará não só uma visão de literatura, mas uma visão de mundo em termos literários.

Se em Plata quemada, enfim, Piglia parece ter buscado realizar a crítica através da ficção, em forma de relato policial, objetivo almejado em alguns de seus textos teóricos, o que resta ao leitor? Não transgredir junto com o texto é sempre uma opção: basta ler no romance só uma narrativa criminal. A outra, em tese mais rica e prazerosa, é jogar o jogo e expor-se, inclusive, ao erro, a sair do mapa, do texto, e perder-se. É imaginar uma tragédia de uma sociedade fraturada e aterrorizada, a reportagem sobre um sonho transformada em romance, um vozerio de fantasmas do passado e temores do futuro. Ou, simplesmente, fantasiar por um momento que Plata quemada não é, na verdade, um romance de Ricardo Piglia, mas o romance policial que escreveu Emilio Renzi, utilizando como pseudônimo o nome deste renomado professor nascido em Adrogué. 


\title{
Capítulo 3
}

\section{Literaturas em contato}

\author{
Também não faz parte de minha tese sustentar que a história \\ de detetive seja uma vital e significativa forma de arte. \\ Não existem vitais e significativas formas de arte; \\ existe apenas arte, e esta é rara. \\ “A simples arte de matar", Raymond Chandler
}

Feitas as primeiras análises de La pesquisa e Plata quemada, resta realizar a interpretação sobre como se dá a relação do gênero policial com as narrativas de Juan José Saer e Ricardo Piglia pela leitura dos romances. O primeiro passo para isto é buscar definir o que se busca com esta operação.

Um primeiro caminho seria o de identificar nos romances de Saer e Piglia marcas do gênero, que, por sua vez teria de ser definido de antemão. Entretanto, há, neste caso, as dificuldades já discutidas em se definir não somente o conceito de gênero de maneira inequívoca, como também quais seriam as marcas únicas e indistinguíveis do policial. Uma definição extremadamente rígida do policial parece, neste sentido, só ser possível se tomarmos o conceito do gênero como uma categoria da literatura de massas e da indústria cultural. Este não parece ser o melhor rumo a seguir, visto que por ele seriam desperdiçadas todas as sutilezas que se podem encontrar, por exemplo, quando se lê um texto como policial, independentemente dos rótulos editoriais que se atribuam a ele. Despreza-se, em suma, a consideração do gênero como uma categoria de leitura - ou até de "estratégia de escritura", como foi visto no caso de Piglia.

Uma segunda possibilidade seria a de inverter a lógica da análise e buscar ver como os escritores exercem suas práxis narrativas singulares trabalhando dentro do gênero policial. 
Este procedimento, entretanto, exige também uma definição prévia do gênero para que se identifiquem adequações e transgressões à sua norma e apresenta o mesmo problema do procedimento anterior: a virtual impossibilidade de uma definição rígida do que é o policial ou a inutilidade de se estabelecer uma. Além disto, o problema, na verdade, se duplica, dada a necessidade, também impossível ou infrutífera, de se conceber uma práxis narrativa estanque para cada um dos autores.

Em resumo, ambos os casos tendem a implicar um trabalho excessivo com categorias taxonômicas estanques e pressupõem certo desprezo à individualidade e particularidade dos textos, dos escritores e do próprio fazer literário. O caminho restante, portanto, parece ser o mais viável e interessante: o de se estabelecer como se dá uma dinâmica entre o gênero e as narrativas singulares. Busca-se, assim, chegar ao processo pelo qual as escritas de Saer e Piglia se relacionam com o gênero policial sem que se lhes atribua um rótulo editorial ou lhes enquadre em uma categoria estanque. Por outro lado, tenciona-se também observar como o gênero pode ganhar novas abordagens e ser visto sob novas perspectivas, reconfigurando-se a partir das escritas autorais, sem que se dissolva por completo.

\subsection{Limites e transgressões}

Para que este processo de "inter-participação" entre o gênero e os textos se realize, voltamos ao conceito de transgressão e ao "Prefacio a la transgresión", de Foucault. Neste texto, o filósofo francês afirma (1999, p. 167):

La transgresión es un gesto que concierne al límite [...] El límite y la transgresión se deben mutuamente la densidad de su ser: inexistencia de un límite que no podría absolutamente ser franqueado y vanidad a cambio de una transgresión que no franquearía más que un límite de ilusión o de sombra. Pero, ¿tiene el límite una verdadera existencia fuera del gesto que gloriosamente lo atraviesa y lo niega? 
O texto de Foucault, que se insere em uma discussão sobre o escritor Georges Bataille, discorre sobre a sexualidade, a morte de Deus e a linguagem, sem, no entanto tratar especificamente da questão do gênero na literatura. O diálogo que se propõe aqui entre o conceito formulado em um contexto filosófico e a forma literária não deixa de ser, por si, uma espécie de transgressão, que faz com que o "Prefacio a la transgresión" participe desta tese do mesmo modo que esta procura participar também das ideias do filósofo. De qualquer modo, há outros pontos de permeabilidade entre os romances analisados aqui e o "Prefacio a la transgresión": a sexualidade transgressora pela homossexualidade de Dorda e Nene ou a degeneração sexual do assassino de velhinhas parisienses; os ruídos de linguagem em ambos os romances; a ideia da morte de Deus no materialismo confuso e desesperado dos bandidos portenhos e no vazio existencial de Pichón e Tomatis no período pós-ditadura. Na relação dos textos, suas tramas e seus personagens, com o gênero policial, emerge também uma linguagem de transgressão que parece ser a única linguagem viável para o relato do crime, da investigação e da verdade, ecoando, de certa forma, outra afirmação de Foucault: "El siglo XX ha descubierto sin duda las categorías emparentadas del gasto, el exceso, el límite, la transgresión: la forma extraña e irreductible de esos gestos sin retorno que consumen y consuman.” (1999, p. 178)

É importante, ainda, ressaltar o caráter de movimento no gesto da transgressão: um movimento que não destrói o limite ou o que ele contém, como tampouco cria um novo campo contrário ao que foi transgredido. Voltando a Foucault (1999, p. 168):

La transgresión no es pues al límite como lo negro es a lo blanco, lo prohibido a lo permitido, lo exterior a lo interior, lo excluido al espacio protegido de la morada. Más bien está ligada a él según una relación en espiral con la que ninguna fractura simple puede acabar. [...] No hay nada negativo en la transgresión. Afirma el ser limitado, afirma ese ilimitado en el que salta abriendo-lo por primera vez a la existencia. Puede decirse sin embargo que esa afirmación no tiene nada de positivo: ningún contenido puede vincularla, ya que por 
definición ningún límite puede retenerla. Tal vez no es otra cosa sino la afirmación de la partición [partage]. Y aun habría que aligerar a esta palabra de todo lo que puede recordar el gesto del corte o el establecimiento de una separación o la medida de una distancia y dejarle solamente lo que en él puede designar el ser de la diferencia.

A transgressão, tal como o conceito é formulado por Foucault, se dá, portanto, em um movimento que impede a síntese dialética. Ou seja, a transgressão do gênero realizada pelo texto não resulta em um novo conceito estável de gênero, mas no movimento contínuo de desestabilização dos gêneros anteriormente estabelecidos. Será, portanto, nas transgressões entre os discursos - os romances, os gêneros, a crítica, esta própria tese - que se buscará um diálogo que possa revelar um pouco mais sobre a práxis narrativa de Juan José Saer e Ricardo Piglia na literatura contemporânea.

\section{Modelos e contextos}

Na longa e árdua discussão sobre a definição de gênero literário, uma das possibilidades é a de se tomar como um dos gêneros fundamentais a representação ficcional mimética - que pode se manifestar nas formas épica ou dramática (seguindo-se a concepção de Käte Hamburger (1986)). A partir disto, pode-se considerar a narrativa em prosa, portanto, já como um subgênero de um dos gêneros primordiais. O romance moderno, neste caso, seria um subgênero em um nível inferior e o romance policial representaria ainda uma subdivisão além da anterior. Entretanto, ainda que simplifiquemos as coisas ao falar simplesmente de gênero policial, o termo ainda está longe de designar uma representação coesa de um conceito. Como aponta Todorov (2003a), a narrativa dita policial pode ser dividida em ao menos duas vertentes: a surgida ainda no século XIX, que se desenvolveu primeiramente na Europa, e que pode ser definida como a "narrativa de enigma", e a surgida no século XX, nos Estados Unidos, chamada de "narrativa dura", romance negro ou hardboiled. Com uma série 
de características diferentes, ambas são tomadas vulgarmente como literatura policial, mas devem ser entendidas em suas especificidades em um estudo sobre o gênero.

Deixando de lado, por enquanto, o gênero tal qual entendido pela indústria cultural, passemos a analisar o policial como uma categoria de leitura e uma forma de manifestação histórica da narrativa. Sob este ponto, um virtual consenso aponta Edgar Allan Poe como o pioneiro e idealizador do gênero, ainda que vários críticos, como Elvio Gandolfo em El libro de los géneros (2007), mencionem antecedentes notáveis como Zadig, de Voltaire, ou as Memórias de Vidocq - especialmente pela presença de elementos da metodologia analítica na resolução de problemas na trama, ainda que esta não seja dominante nas narrativas. De qualquer modo, a consolidação de uma forma narrativa como gênero policial se dá, de fato, com Poe em seus contos com o detetive Dupin: "Os crimes da Rua Morgue" (1841), "O mistério de Marie Rogêt" (1842) e "A carta roubada” (1844).

A partir de Poe, seguem-se não somente outros contos policiais como surgem também romances policiais. Estas diferenças de formato dos textos - mais um problema na definição do gênero - parecem não invalidar, entretanto, a noção de uma narrativa policial, que se serve do conto e do romance como gêneros narrativos em seu apogeu no século XIX ${ }^{109}$. Além disto, como aponta Franco Moretti (2007, p. 174-5):

Uma história policial pode durar dez ou duzentas páginas e nada muda; a ficção policial tem sempre a estrutura do conto (segundo a definição dos formalistas russos, que parece ser a mais exata). Quando assume as dimensões e o nome de romance, só é romance no número de páginas que ocupa - ou seja, em termos físicos não estruturais.

\footnotetext{
${ }^{109}$ Esta característica da narrativa policial de se adaptar a formas distintas em diferentes contextos históricos terá outro exemplo no surgimento precoce do gênero policial no cinema - grande espaço da narrativa a partir do século XX. Histórias do criminoso Fantômas, clássico personagem do policial francês, já são adaptadas ao cinema em 1913 e filmes de gângsteres já são frequentes no cinema norte-americano desde a década de 1920.
} 
Este aspecto fundamental da estrutura da narrativa policial, apontado por Moretti, voltará a ser analisado mais adiante, mas, por agora, é necessário pensar que aspectos - além dos estruturais - configuram o policial enquanto gênero em um contexto histórico específico.

O método analítico apresentado por Poe já no início de "Os crimes da Rua Morgue” (1841) pode ser considerado como a primeira marca distinguível do gênero policial. É a partir dela que se constrói o personagem do detetive - Dupin, em primeiro lugar, e depois Sherlock Holmes, Rouletabille, Poirot, Maigret e infinitos outros - e a própria lógica da narrativa: contar o processo de solução de um crime pela investigação, observação e deduções de uma mente analítica. Se por um lado este procedimento remete fortemente a um ambiente cultural que se liga às descobertas técnico-científicas e à sensação de onipresença e onipotência da ciência $^{110}$, por outro está também indubitavelmente atrelado às modificações socioeconômicas pelas quais passava a sociedade na época. Nesse contexto, a ascensão definitiva da burguesia, o desenvolvimento das metrópoles, o estabelecimento do capitalismo industrial e o surgimento das massas operárias urbanas, o aumento da criminalidade com o consequente surgimento e desenvolvimento da criminologia, são todos elementos que contribuirão direta ou indiretamente para o surgimento do gênero policial ${ }^{111}$. Assim, o mesmo ambiente que permite a consagração do romance como o gênero literário burguês por excelência - pela universalização da educação nesta classe, pelo ainda isolamento das mulheres dos centros econômicos e de poder, etc. - e a grande difusão do conto - por sua crescente difusão na imprensa diária que florescia, por exemplo -, fornece também os elementos que conformarão não somente a temática, como também a estrutura, por consequência, do subgênero policial.

\footnotetext{
${ }^{110}$ É marcante a presença, no decorrer de todo o século XIX e mesmo depois, por exemplo, das ideias positivistas. A preponderância do pensamento e dos métodos científicos e da aspiração ao conhecimento unicamente através deles relaciona-se, então, naturalmente a várias características do surgimento do gênero policial. Carlo Ginzburg, em "Sinais: Raízes de um paradigma indiciário", afrima, por exemplo, que: "A metáfora da 'anatomia da sociedade', usada numa passagem crucial também por Marx, exprime a aspiração a um conhecimento sistemático numa época que vira enfim o desmoronamento do último sistema filosófico, o hegeliano." (2002, p. 170-1, grifo meu)

${ }^{111}$ Além de Guinzburg (2002), muitos outros analisam esses fenômenos de transformações na ordem social que contribuem para o surgimento e consolidação do gênero, como Bolle (1994), Storch (1985), Mandel (1988), Moretti (2007) e Pechman (1993).
} 
O policial, entretanto, pode ser lido não somente como surgido a partir de aspectos socioeconômicos e culturais do contexto histórico do século XIX, como também servindo ideologicamente como um suporte à classe dominante nesse mesmo contexto. Tanto Franco Moretti como Ernest Mandel notam essa relação:

E [Sherlock] Holmes é exatamente isso: o grande médico dos últimos vitorianos, que os convence de que a sociedade ainda é um grande organismo, um corpo unitário, que pode vir a ser conhecido. Sua "ciência" é simplesmente a ideologia deste organismo; louva o seu triunfo ligando instantaneamente trabalho e aparência externa (corpo, roupa), reafirmando a ideia da sociedade hierárquica que é externalizada, tradicionalista e fácil de controlar. (MORETTI, 2007, p. 173, grifos do autor)

Embora a criminalização das classes mais baixas seja uma característica particular dos romances anglo-saxões mais "triviais", não é raro se encontrarem assassinos da classe média e até das classes altas nos romances policiais clássicos das décadas de 20 e 30 (os romances de Agatha Christie, por exemplo). O ponto crucial não é a origem econômica do assassino, mas sua apresentação como um desajustado social, um "grosseirão" que infringe as normas da classe dominante e que por este motivo deve ser punido. (MANDEL, 1988, p. 77-8)

A partir daí vai se formando a imagem do gênero policial como alienante, ideologicamente conservador e culturalmente manipulador dentro da sociedade capitalista. Por outro lado, entretanto, se destacam as características de um gênero narrativo com um alto grau de maleabilidade - a despeito das características repetitivas e de fórmulas atribuídas ao policial tanto pelo senso comum como por parte da crítica. Um exemplo disto é a transformação radical por que passa o gênero indo da narrativa de enigma ao romance noir e ao hardboiled. A partir de um contexto histórico - e social, econômico e mesmo geográfico e cultural - distinto, o policial consegue manter-se como gênero a partir de algumas premissas básicas. A estreita relação das narrativas do gênero com esse próprio contexto histórico, por exemplo, se mantém: como as histórias de Sherlock Holmes - criadas pelo conservador e defensor do imperialismo britânico Conan Doyle - nascem da sociedade vitoriana e refletem 
muito de sua ideologia, as de Continental Op - detetive criado pelo comunista Dashiell Hammett - fazem o mesmo com o período da Depressão econômica e da tensão entre guerras nos Estados Unidos. Como cada escritor trabalhará o gênero também pode distorcer e remoldar seus parâmetros, bem como atrelar a ele ideias políticas e sociais em polos opostos. Assim, toda uma ideologia de conservação da ordem social e da legitimação da autoridade da força policial está nas narrativas de G. K. Chesterton do mesmo modo que em seus ensaios como “A Defence of Detective Stories”, de 1901 (1923, p. 229):

There is, however, another good work that is done by detective stories. While it is the constant tendency of the Old Adam to rebel against so universal and automatic a thing as civilization, to preach departure and rebellion, the romance of police activity keeps in some sense before the mind the fact that civilization itself is the most sensational of departures and the most romantic of rebellions. By dealing with the unsleeping sentinels who guard the outposts of society, it tends to remind us that we live in an armed camp, making war with a chaotic world, and that the criminals, the children of chaos, are nothing but the traitors within our gates. When the detective in a police romance stands alone, and somewhat fatuously fearless amid the knives and fists of a thieves' kitchen, it does certainly serve to make us remember that it is the agent of social justice who is the original and poetic figure, while the burglars and footpads are merely placid old cosmic conservatives, happy in the immemorial respectability of apes and wolves. The romance of the police force is thus the whole romance of man. It is based on the fact that morality is the most dark and daring of conspiracies. It reminds us that the whole noiseless and unnoticeable police management by which we are ruled and protected is only a successful knight-errantry.

Em contrapartida, existem escritores como o afro-americano Chester Himes, que aborda a questão do racismo tanto em textos não policiais como na série dos detetives do Harlem Ed "Caixão" e Jones "Coveiro". A autoridade da polícia como mantenedora da ordem e o uso da violência para a manutenção do status quo é questionada pelas narrativas policiais, como no trecho que fala sobre o jovem negro Marcus Mackenzie, personagem de $O$ harlem é escuro (Blind man with a pistol), de 1969 (2006, p. 28-9):

Sua lembrança mais antiga era dos distúrbios raciais em Detroit em 1943, no auge da luta feroz dos Estados Unidos contra outras formas de racismo em 
outros países. Mas ele era jovem demais para compreender essa ironia. Só se lembrava de seu pai entrando e saindo do apartamento deles no gueto, os gritos e tiros da rua que não podia ver, e sua irmã mais velha sentada na sala da frente do seu apartamento trancado e de venezianas fechadas, com um enorme revólver preto no colo, apontado para a porta. Ele tinha quatro anos, e ela, sete. Eles ficavam sozinhos sempre que o pai saía para tentar ajudar outros negros a escaparem da polícia. [...] Ele havia morado durante toda sua vida em uma favela negra, havia frequentado escolas negras e, depois de se formar no ensino médio, tinha conseguido o emprego costumeiro para sua raça em uma sociedade segregacionista, em uma fábrica. Depois tinha sido convocado e mandado para a Alemanha.

Assim, quando o contexto histórico em que nasce o gênero policial se modifica, a relação deste com aquele também sofre modificações, o que demonstra a maleabilidade do policial, mas obriga, por outro lado, que uma abordagem do gênero em relação a dois autores argentinos, como a que se faz aqui, o reconfigure, deixando de lado muitas pré-concepções trazidas dos modelos europeus e norte-americanos, do relato de enigma ou do hardboiled. Por isto, Elvio Gandolfo critica o grande número de casos na literatura argentina em que se tenta emular os modelos estrangeiros - especialmente o norte-americano - de narrativa policial, porque, desse modo (2007, p. 160):

se producía la fractura de verosimilitud: como crear un detective privado en una trama social en la que no existe la necesidad o posibilidad no sólo de existencia real y actuante sino también (lo que es más importante para la novela) de existencia mítica del detective privado. En el plano mítico se sabe que los detectives privados existen en Nueva York o Chicago, nunca en Corrientes o Caballito.

Para que o gênero se realize em literaturas excêntricas com relação aos centros europeus e norte-americanos, como é o caso das latino-americanas, ele deve, então, se modificar pela transgressão aos modelos prévios. Como aponta Ana María Amar Sánchez em "El crimen a veces paga. Policial latinoamericano en el fin de siglo" (2000), o gênero assume na América Latina - nos casos mais bem logrados - características particulares, vinculadas com o contexto político, social e cultural do subcontinente. Já Edgardo Berg (2008b) nota como as transgressões e reconfigurações podem ser, também, um caminho de mão dupla, ou 
seja, como a utilização do gênero de origem estrangeira também ajuda a pensar e redefinir a própria identidade cultural e literária de um país:

\begin{abstract}
Las formas desplazadas, la recuperación de ciertas estrategias narrativas o la lectura en clave afirman un modo de relación que traduce - lleva a otro lugar - un género transnacional y redefine las discusiones entre lo local y lo global, entre lo nacional y extranjero. [...] La identidad cultural muchas veces se define en el diálogo desplazado y lateral con las formas que asume una tradición extranjera. [...] Las formas de distanciamiento, traslado o "traducción" de una forma y un modelo extranjero será postulado, en su forma más extrema, como un imperativo de nacionalización. Los mejores intentos en nuestra literatura hacen que el uso de las convenciones narrativas del género y de las reglas del mismo no se reduzcan, simplemente, a la simple transposición de códigos, figuras y estereotipos.
\end{abstract}

A análise das relações de La pesquisa e Plata quemada com o gênero policial, então, passa pela observação não só das transgressões aos modelos estrangeiros, dos modos como se dão os traslados e as traduções desses modelos. É necessário também ver como Saer e Piglia formulam suas concepções de gênero a partir de suas práxis narrativas - já bem desenvolvidas quando da publicação dos romances - e de uma tradição cultural e literária em que se inserem. É preciso pensar como o movimento de interação entre o gênero e os textos é um processo dinâmico em que inúmeras transgressões reconfiguram limites para o próprio gênero, bem como para os projetos estéticos dos autores dos romances

\title{
Um contexto para o policial
}

A relação de Ricardo Piglia com o gênero não pode ser considerada propriamente sui generis, já que o escritor chegou a editar uma coleção de traduções de policiais norteamericanos na Argentina e características do policial são apontadas em outros de seus textos, além de Plata quemada. Já no caso de Juan José Saer, a presença do gênero policial certamente parece menos "natural", ao menos da maneira como aparece em La pesquisa. O 
próprio autor afirma, no ensaio sobre o romance incluído em La narración objeto: "Aunque en varias de mis narraciones introduje deliberadamente ciertos elementos de la novela negra, abordar de un modo directo el género policial implicaba muchos problemas" (1999, p. 159). Em contrapartida, Saer parece satisfeito com o fato de ter escrito o romance: "porque el hecho de haber escrito un relato policial me otorgó [...] una especie de equilibrio entre la tensión de un trabajo adulto y el placer del abandono a una imaginación infantil” (p. 160), enquanto Piglia afirma em uma entrevista dada a Guillermo Mayr (2009b): “...no soy un escritor de policiales [...] El género está presente en mi literatura sin que yo escriba directamente narrativa policial." A primeira questão, então, não é propriamente descobrir o gênero em Saer e Piglia, mas descobrir com que características o gênero é concebido de maneira específica e como este se insere em um projeto estético-literário mais amplo de cada autor.

Uma maneira de se conceber o gênero literário, como já foi visto, é tomá-lo como uma categoria de leitura: sob este ponto de vista, a expectativa do leitor diante do texto configura o gênero mais do que propriamente a "intenção" do escritor - será "policial" o que o leitor ler como "policial". ${ }^{112}$ Assim, nossa leitura pode indicar que o gênero policial com que dialoga Saer em La pesquisa é essencialmente o clássico, o do romance de enigma. Se Morvan não é propriamente um Dupin, um Sherlock Holmes ou um Maigret, há de qualquer modo a questão essencial da resolução do mistério: quem é o responsável pelos assassinatos de velhinhas em um bairro parisiense? Por outro lado, em Plata quemada, a narrativa remete claramente ao romance duro, ao hardboiled. Ainda que aqui não haja tampouco um detetive durão como Sam Spade ou Philip Marlowe, a narrativa privilegia sem dúvida a ação e a relação dos personagens entre si e com a sociedade e a solução de um mistério não se coloca nunca em

\footnotetext{
112 Jorge Luis Borges afirma, em "O conto policial” (1999a), que "os gêneros literários dependem, talvez, menos dos textos que do modo como estes são lidos” (p. 220-1) e que um leitor de policiais que hipoteticamente não tivesse nunca sequer ouvido falar da obra de Cervantes, ao começar a ler pela primeira vez o Quixote, adotaria uma postura desconfiada, esperando no texto uma série de crimes, intrigas e mistérios. Por outro lado, no mesmo texto Borges também atribui a origem desse leitor de policiais a um escritor: "Nós, ao lermos um romance policial, somos uma invenção de Edgar Allan Poe” (p. 227).
} 
primeiro plano. Entretanto, esta divisão estanque - La pesquisa / relato de enigma; Plata quemada / relato duro - empobrece a análise e contradiz a concepção do gênero maleável e indicado à transformação pela transgressão ao relacionar os romances a contextos que lhe são, literalmente, estrangeiros, em lugar de fazê-los dialogar com seu contexto próprio: o da literatura argentina no final do século XX.

A relação de Plata quemada, por exemplo, com o romance duro - o hardboiled - não é a mesma que o gênero estabelece com Red harvest (1929), de Dashiell Hammett, ou The long goodbye (1953), de Raymond Chandler, nos contextos norte-americanos dos períodos de entre guerras e pós-guerra, respectivamente. Na Argentina dos anos 1990, os elementos tradicionais do romance policial duro servem, no romance de Piglia, a uma narrativa que procura se constituir como um discurso de um momento histórico específico, em uma sociedade específica. Não se trata de "adaptar" o hardboiled à Argentina, onde não abundam detetives particulares idealistas, mas de servir-se de seu modelo narrativo para mostrar que no lugar do "tira durão" pode estar um torturador a serviço do estado, que a conspiração não está só no mundo do crime, mas na sociedade toda, que se, enfim, a narrativa policial dura norteamericana funciona como um discurso social dentro daquela sociedade, o gênero ganha forma própria como discurso social em outra sociedade, no caso a argentina. Para Edgardo Berg (2008b), inclusive, a narrativa de Piglia - não só em Plata quemada - se relaciona com o gênero policial de uma maneira que já suplanta o hardboiled e se diferencia dele:

En este sentido, en 1991, Piglia [...] esboza una nueva categoría narrativa asociada al registro policial: la ficción o relato paranoico. Trazando la historia del género a partir de la constitución de la figura del detective y entablando una relación, entre los modos ficcionales y las formas que la sociedad asume en tres momentos históricos bien diferenciados, y que, a su vez, corresponden a las tres modalidades del género policial - de enigma, negro o duro y el relato paranoico -, formula la hipótesis de un cambio en el registro, a partir de la constitución de la subjetividad en las sociedades actuales, regidas por los órganos de control estatal y el desarrollo de la seguridad privada. 
No romance policial duro, no hardboiled, ou no romance negro muitas vezes não há enigma ou este não se constitui como o aspecto central da narrativa. Plata quemada se insere neste cenário ao narrar os crimes do ponto de vista dos criminosos e não há mistério para o leitor sobre quem roubou o carro forte em San Fernando, que outros crimes os bandidos cometeram nem para onde fugiram, mas sim sobre a enorme rede de intrigas que se oculta por trás do roubo. A narrativa passa então a ser uma tentativa de reconstituição de uma história que, ao fim, não se deixa revelar por completo. O complô, que parece ser em certo ponto como uma parte ou uma amostra de toda uma sociedade fundada na conspiração, é ao mesmo tempo o objeto da narrativa e seu maior obstáculo. O contexto em que Plata quemada se insere no gênero policial, então, é o da sociedade argentina dos anos 1990, mas é também, a partir daí, o de uma tentativa de reconstituição desse contexto nos anos 1960, prévio às ditaduras militares no país. A literatura policial que se realiza pelo complô e pela paranoia reflete, então, o complô do estado em relação à violência dos regimes autoritários que se gestam no passado bem como o complô econômico que domina a sociedade no presente da publicação do livro (1997) sob a forma do estado neoliberal dos anos do governo Memem (1989-1999). A trama reconfigura, então, as imagens da violência, da lei, do dinheiro e da contravenção - tradicionais do gênero policial - no contexto argentino dos anos 1990. Além disso, as reconfigura no contexto de uma tradição cultural que tem Jorge Luis Borges, Roberto Arlt, Rodolfo Walsh e outros trabalhando com as mesmas imagens. Neste processo, também uma nova forma para o policial surge como necessária para essas reconfigurações, como se verá mais adiante.

La pesquisa, por sua vez, trabalha também com as relações entre passado e presente, apresenta uma referência ao gênero policial - na forma do relato de enigma - e, publicado em 1992, comparte com Plata quemada um contexto cultural bastante semelhante. O romance de Saer, entretanto, se insere em outra práxis narrativa e gera uma relação com o gênero muito 
distinta à de Piglia. Enquanto o presente da trama de La pesquisa deve se situar ${ }^{113}$ em algum momento na segunda metade da década de 1980 - anterior, portanto, ao período mais agudo das políticas neoliberais -, o passado a que estão ligados, especialmente, os personagens Pichón e Tomatis é o das ditaduras militares dos anos 1970, com seus sequestros e assassinatos. A relação com o relato de enigma, surgido ainda no século XIX, se problematiza, então, no contexto cultural distinto em que se apresenta, dadas as evidentes diferenças entre a Inglaterra Vitoriana de Sherlock Holmes, as propriedade rurais aristocráticas em que muitas vezes atua Poirot, ou mesmo a Paris urbana de Maigret, e a Argentina em fins do século XX. Novamente por uma adaptação - não somente à Argentina, mas também à poética de Saer - feita na forma como se constrói o relato, este surge pela boca de Pichón, o personagem argentino que narra aos amigos a história passada na França. A violência criminal e a barbárie ocorrida na Europa passam a contrastar, então, com o clima quase bucólico da Argentina, cenário de uma viagem de férias e de discussões intelectuais. O jogo de inversões com os espaços da civilização e da barbárie, tão caros à construção da identidade cultural argentina, não deixam de revelar, no entanto, as fissuras no aparentemente tranquilo - mas também angustiosamente vazio - presente de Pichón e Tomatis, causadas pela violência e os traumas do passado. Em La pesquisa, uma leitura por sua afiliação à tradição do relato de enigma - a bem da verdade, mais aparente do que presente, já que não há quase suspeitos do crime e o raciocínio analítico para sua resolução é, no mínimo, pobre - não redunda no mesmo efeito de apaziguamento social e exaltação da lei e da ordem tantas vezes presente nessa tradição.

\footnotetext{
${ }^{113}$ Pelo que podemos deduzir também por outras narrativas do autor em que os mesmos personagens aparecem, como o romance Glosa (1985) e vários contos, por exemplo.
} 


\section{Distorsões}

É possível assumir que La pesquisa e Plata quemada dialogam com o gênero policial desestabilizando-o. Um dos motivos para esta desestabilização é, como foi visto, que a relação que o gênero tinha com os contextos em que surgiram anteriormente - seja a Inglaterra vitoriana, seja o período da Lei Seca norte-americana - contrastam com o contexto em que Saer e Piglia desenvolvem suas narrativas - a Argentina de fins do século XX. Tal constatação, no entanto, é pobre e insuficiente para a análise que se propõe aqui por, pelo menos, dois motivos. Por um lado porque, se o policial se transfigura de acordo com os diferentes contextos em que surge, é igualmente verdade que tal característica pode ser constatada nos gêneros literários em geral: a poesia lírica de Castro Alves guarda relações com o contexto histórico em que surgiu e se diferenciará da também poesia lírica que podemos ler como gênero na poesia de Manuel Bandeira, surgida em outro contexto; é possível ler o romance enquanto gênero manifestado em Stendhal, Balzac, Joyce ou no nouveau-roman. Por outro lado, ainda que a constatação ajude a rechaçar - ou, ao menos, atenuar ou relativizar - certas leituras do policial como gênero estanque, atrelado a certas ideologias e fórmulas, ela nos força a buscar, então, a(s) marca(s) do policial que são mais ou menos perenes e impedem que o gênero se descaracterize por completo e impeça uma leitura pelo viés genérico. Dito de outro modo, se La pesquisa e Plata quemada se desvencilham das leituras que os relacionam a modelos prévios do policial - o que pode livrá-los do julgamento de pobreza literária de um gênero da literatura de massa, mas também afastá-los da relação com o policial -, o que garante a possibilidade de relacioná-los com o gênero? Se a história do assassinato das velhinhas é só um relato do personagem Pichón em La pesquisa e se a trama de Plata quemada não apresenta um detetive - ainda que apresente crime -, não tem a construção de um mistério - ainda que tenha suspense - e não mostra um processo de 
raciocínio analítico - só recorta vozes dispersas que mal dão conta de contar a história -, onde está o policial?

Um dos elementos comuns em muitos relatos policiais, sejam eles da vertente de enigma, dura, negra, hardboiled, ou como se queiram classificá-las, é o papel dos jornais nas narrativas do gênero. Desde os contos policiais pioneiros de Poe, a imprensa se coloca como figura frequente nos relatos, desempenhando diversos papéis, mas eminentemente pondo em relevo a questão da verdade em sua relação com o relato e se colocando como uma narrativa dentro da narrativa - esta, talvez, a característica mais marcante do gênero e de sua modernidade como manifestação literária. É a respeito dessa relação que Daniel Link afirma que, além de transbordar os limites da literatura, a "outra razão que torna interessante o policial é estrutural: o policial é um relato sobre o Crime e a Verdade.” (2002, p. 73)

Com relação aos jornais, o narrador da história policial em La pesquisa, Pichón, aparenta até uma ingenuidade na defesa da história que conta aos amigos: ela se sustenta, se legitima, pela proximidade do narrador dos fatos e pela autoridade dos jornais: a história é "boa" porque é "real" e é "real" porque saiu em todos os jornais. Já em Plata quemada o narrador também recorre aos jornais como base para os fatos narrados, mas de maneira mais neutra: a história narrada teve por base os jornais, eles são a "comprovação" dos fatos, mas não são defendidos como detentores de toda a verdade. Na verdade, o recurso à autoridade dos jornais é de certa forma transgredida em uma análise mais aprofundada. A instância narrativa primária de La pesquisa, aquela que narra a viagem de Pichón a Santa Fe, não recorre aos jornais, é o personagem que se transforma na instância narrativa secundária quem põe em questão o clichê do gênero dos jornais como fonte da verdade, é ele quem traz a ingenuidade que vai ser contestada por Tomatis. No caso de Plata quemada, uma chave para uma interpretação divergente está no "Epílogo": ali o narrador defende os jornais como base documental para o caso narrado, mas coloca como um dos responsáveis pelos textos 
jornalísticos um personagem, também uma instância narrativa secundária, Emilio Renzi. As estratégias, embora um pouco diferentes, ressaltam um elemento comum: a transgressão do gênero pela distorção de um de seus elementos marcantes, o uso dos jornais na narrativa ${ }^{114}$. Esta transgressão reside no fato da estratégia estar desnudada: Tomatis desdenha a posição de Pichón em amparar-se nos relatos da imprensa em La pesquisa; o narrador do Epílogo de Plata quemada cita, ironicamente, um personagem fictício do próprio romance como autor da narrativa jornalística. $\mathrm{O}$ efeito dos jornais nas narrativas policiais mais tradicionais $-\mathrm{o}$ de elemento verossímil dentro do espaço diegético da trama - desaparece quando se põe em evidência seu caráter de artifício narrativo em ambos os romances. Além disso, a distorção não ocorre simplesmente por causa de intenções paródicas, não leva unicamente a uma reflexão sobre os próprios mecanismos constitutivos do gênero.

A notícia de jornal, na verdade, é somente um dos elementos que caracteriza o gênero policial de maneira mais ampla: o fato de ser uma narrativa sobre outras narrativas. $\mathrm{Na}$ vertente clássica da narrativa de enigma isto é mais claro: seja pelos jornais, por depoimentos de testemunhas e suspeitos ou pela leitura de pistas, o que se narra é a reconstituição de uma narrativa anterior à que lemos, a narrativa do crime. Dito de outro modo, há neste tipo de policial uma trama, a do crime (que só se revela por completo no final da narrativa), há outra trama, que é a do raciocínio do detetive (muitas vezes com pouca ação de fato), e por fim, muitas vezes, a narrativa do amigo ou auxiliar do detetive que dá conta das outras duas. Um exemplo deste mecanismo surge quando lemos a narração do Dr. Watson sobre a investigação de Sherlock Holmes sobre um crime cometido anteriormente. Indo além, é possível, no gênero policial, extrapolar a literatura, como aponta Link (2002, p. 71):

\footnotetext{
${ }^{114}$ Que, em resumo, como já foi visto, são: os jornais como fonte segura da verdade dos fatos, como uma fonte falha ou ambígua dela, ou como manipuladores da verdade.
} 
Se o policial suscita a atenção de teóricos a princípio alheios à literatura, é porque se trata de um gênero que extrapola, desde a sua própria origem, os limites literários. Mais ainda, o material discursivo a partir do qual o gênero policial é possível (o caso policial) precede a literatura policial. Trata-se das crônicas: "O mistério de Marie Rogêt", um dos três contos de Edgar Allan Poe que codificam o modo de funcionamento do conto policial, não é senão uma leitura pormenorizada de crônicas policiais, a partir das quais, supõe-se, o narrador "descobre" a verdade dos fatos.

$\mathrm{O}$ caso e a crônica policial precedem o gênero policial, porém, o gênero policial não procede da crônica nem do caso e sim da dinâmica interna da série literária. Esta relação complicada talvez explique o fator expansivo do gênero policial (algo de si o precede, excedendo o marco do específico literário) e a rapidez com que conseguiu se impor em outros campos culturais (estéticos ou não).

Ou seja, desde sua concepção, o gênero policial é um discurso que se constrói sobre outros discursos, o que é provavelmente uma de suas características mais marcantes e, além disso, um traço de sua modernidade - se o tomarmos como um fator de autoconsciência do texto de seu caráter como construção artificial da linguagem. Franco Moretti, em "Pistas" (2007), parece acertar, então, ao considerar essencial Watson nas histórias de Sherlock Holmes como "função literária", mas se equivocar ao afirmar que: "Enquanto o criminoso inicia a ação e o detetive a encerra, Watson a prolonga. Sua função específica é puramente quantitativa. [...] Mas a função específica de Watson é quantitativa de uma forma mais profunda: ele acumula detalhes inúteis.” (p. 174, grifo do autor) Aqui, Moretti parece pensar não na literatura, mas só no crime e no raciocínio analítico, como o faz o próprio Holmes, que censura Watson frequentemente por suas crônicas cheias de detalhes inúteis. Ainda assim, mesmo o detetive parece se dar conta da especificidade da literatura como discurso construído em "O rosto lívido", um dos dois únicos contos do cânone sherlockiano não narrados por Watson (CONAN DOYLE: 2011a, p. 50):

Embora limitadas, as ideias do meu amigo Watson são extremamente pertinazes. Durante muito tempo ele me importunou, querendo que eu relatasse uma de minhas próprias experiências. Talvez eu mesmo tenha estimulado essa insistência, pois muitas vezes tive oportunidade de lhe mostrar como seus relatos são superficiais e de acusá-lo de agradar ao gosto popular em vez de se limitar rigorosamente aos fatos e números. "Tente 
fazer isso você mesmo, Holmes!" ele retrucava, e sou forçado a admitir que, agora que tenho a caneta na mão, começo de fato a perceber que o assunto precisa ser apresentado de uma maneira que possa interessar ao leitor.

A profusão de discursos nos romances de Saer e Piglia pode, então, dialogar com o gênero policial pela mesma característica que este apresenta: a de desnudar a artificialidade da literatura como discurso construído. Em La pesquisa, este tipo de narração em abismo se dá com o narrador contando a viagem de Pichón a sua cidade natal, onde este conta a história de uma investigação sobre crimes acontecidos anteriormente em Paris. Assim, é desta marca de artificialismo do gênero policial, o gênero que narra sobre outras narrativas, que se serve Saer para adequar uma história policial à sua "maneira", à sua práxis narrativa. A discussão sobre a impossibilidade de narrar, uma constante de sua obra, encontra um terreno fértil na história de detetives quando esta é questionada no interior do romance. Com a reivindicação de Tomatis de que "cada coisa deve ser perfeita em seu gênero", explicita-se, ironicamente, a impossibilidade de tal coisa: os fatos tais como foram, como "apareceu em todos os jornais", como os narra Pichón, são imperfeitos para a narrativa do gênero, ou para qualquer narrativa. Esta, sem ser menos "verdadeira", é obrigatoriamente uma ficção, uma construção artificial que obedece somente a regras internas e únicas em cada caso. O romance policial de Saer desnuda as imperfeições das convenções do gênero na busca pela perfeição do texto que é o exemplar único do romance policial saeriano.

Já em Plata quemada, Piglia faz também dos elementos do gênero elementos de sua própria práxis narrativa. A profusão de versões sobre o crime se converte no romance pensado como $^{\text {arquivo }}{ }^{115}$, na proposta de literatura como a voz do outro ${ }^{116}$, e a investigação no romance se transforma na própria forma da narrativa e em seu discurso crítico ${ }^{117}$. E, ainda

\footnotetext{
${ }^{115}$ Sobre Respiración artificial, Piglia já afirmara, em entrevista de 1989, publicada em Crítica y ficción: "Me tentaba la idea del archivo como forma". (2001a, p. 112)

${ }^{116}$ Uma das propostas de Piglia em "Tres propuestas para el próximo milenio (y cinco dificultades)" é a de que: "La literatura sería el lugar en el que siempre es otro el que habla." (2001a, p. 19)

117 "En más de un sentido el crítico es el investigador y el escritor es el criminal. [...] Me interesa mucho la estructura del relato como investigación.” (PIGLIA, 2001a, p. 15-6)
} 
assim, a transgressão ao gênero acontece quando, por exemplo, os múltiplos discursos em Plata quemada não se organizam de uma maneira hierárquica, ou seja, quando não é a voz do detetive - o que seria também dizer a voz da lei instituída pelo estado - a que se impõe a todas as outras e dá o sentido último do relato. A ideia da literatura como a voz do outro é levada a sério, especialmente quando se leva em conta que esse outro representa a contracara da sociedade, oposta ao discurso do Estado e da lei.

\subsection{O gênero e as formas da narrativa}

Se é possível fazer uma leitura de La pesquisa e Plata quemada como romances que dialogam com o gênero policial, outra questão que surge é como estes romances dialogam com outros textos dentro das poéticas narrativas desenvolvidas por Juan José Saer e Ricardo Piglia e com suas próprias concepções de narrativa e romance.

No caso de Piglia é o próprio escritor quem afirma que, em sua narrativa, "el género policial ha funcionado como una estrategia narrativa fundada, básicamente, en la idea del relato como investigación” (2009). Assim, é relativamente fácil ver como a estratégia relacionada ao policial, a da narrativa como investigação, aparece em Respiración artificial, La ciudad ausente ou Blanco nocturno. Curiosamente, ao contrário dos outros romances, é em Plata quemada que não há um dos personagens principais investigando algo. Quem o faz - ou pode fazê-lo - são os jornalistas, é o narrador, é o leitor. A peculiaridade de Plata quemada em relação às outras narrativas do autor passa, então, pelo uso do gênero policial ou pelo uso peculiar que se faz dos mecanismos do gênero policial?

Saer, por sua vez, aponta que, ao mesmo tempo em que elementos do gênero estão presentes em ao menos parte de sua obra, La pesquisa, como romance policial, guarda certas particularidades por ser uma abordagem mais direta do gênero (1999, p. 159). Por outro lado, 
são justamente estas peculiaridades as saídas que o escritor encontrou para adequar o romance à sua poética, a mesma que sempre procurou desenvolver com coerência em Nadie nada nunca, El entenado ou Glosa.

De qualquer maneira, o conceito de romance é uma questão problemática nas discussões teóricas de ambos os autores e o desenvolvimento de suas narrativas não poderiam ignorá-la ou contorná-la. A questão, então, é encontrar como se realizam, de acordo com as práxis de Saer e de Piglia, certos conceitos de narrativa e romance em La pesquisa e Plata quemada, mantendo ainda em vista as interações dessa discussão com a do conceito de gênero policial.

\section{Concepções de narrativa}

Muchos malentendidos pesan sobre la novela. El primero y tal vez el más grande, es el nombre mismo del género. Todavía se sigue llamando novela a un trabajo que, desde Flaubert, se ha transformado ya en otra cosa y que los malos hábitos de la crítica perezosa siguen confundiendo con la novela.

Quando Juan José Saer escreve isto, em 1981, no ensaio "La novela", publicado em El concepto de ficción (1997a, p. 128), reflete uma preocupação com a narrativa que perpassa muitos dos outros ensaios do livro ${ }^{118}$ e uma discussão que, hoje, se aproxima de completar, pelo menos, um século: o que é o romance enquanto gênero?

Mikhail Bakhtin (Estética da criação verbal, 2010; Questões de Literatura e de Estética, 2002), especialmente, serve de modelo para uma análise do romance como gênero contemporâneo e em desenvolvimento, atribuindo ao conceito, portanto, a essência de ser uma realização histórica ${ }^{119}$. Neste sentido, é possível pensar o romance como uma modalidade

\footnotetext{
118 Para ficar em alguns exemplos: "Narrathon" (p. 145-58), "Notas sobre el noveau roman" (p. 177-85), "La novela y la crítica sociológica" (p. 232-40) e "Borges novelista" (p. 282-90).

${ }^{119}$ A este respeito, ver, por exemplo, "O discurso no romance" - "O romance é um gênero literário. O discurso romancesco é um discurso poético, mas que, efetivamente, não cabe na concepção atual do discurso poético. Na
} 
narrativa, mas não como um sinônimo da épica, ou seja, como um gênero com características singulares vinculadas a um momento histórico específico. Por outro lado, o romance como uma manifestação moderna o situa em uma categoria de análise ainda aberta e suscetível a evoluções e transformações. Daí a relutância de Saer em atribuir o nome "romance" à produção narrativa pós-vanguardista - ou a parte dela, ao menos, o que revela, por outro lado, um Saer como leitor de Adorno ${ }^{120}$.

Mas se o romance surgido no século XIX é concebido como próprio e inextricavelmente ligado a um contexto social, político, econômico e cultural específico - "O romance foi a forma literária específica da era burguesa." (ADORNO, 2003, p. 55) -, também é possível associá-lo a um contexto também geográfico, o que leva a um outro tipo de reflexão feita por Ricardo Piglia no caso específico da argentina - “¿existe una forma nacional de usar la ficción?” (2001, p. 75) ${ }^{121}$. Adventos como as Vanguardas artísticas e literárias, as guerras mundiais, a Revolução Russa e o socialismo como forma de governo em escala global, a ascensão política e ideológica norte-americana, as descobertas técnicocientíficas e as consequentes transformações sociais devem configurar um novo contexto para o século XX. Entretanto, a forma como a percepção deste novo contexto vai se formando aos poucos e atua na concepção da narrativa romanesca a partir da formada em relação ao romance burguês do século XIX pode ser vista de diversos ângulos. É possível abordar a questão do gênero na narrativa tanto a partir de parâmetros mais amplos - suas

\footnotetext{
base desta concepção estão algumas premissas limitadoras. Esta mesma concepção no processo da sua formação histórica, de Aristóteles aos nossos dias, orientou-se para gêneros 'oficiais' definidos e esteve ligada a certas tendências históricas da vida verbal e ideológica. Por este motivo, toda uma série de fenômenos permaneceu fora de sua perspectiva." (2002, p. 80) - e "Epos e Romance (Sobre a metodologia do estudo do romance)" - "O estudo do romance enquanto gênero caracteriza-se por dificuldades particulares. Eles são condicionados pela singularidade do próprio objeto: o romance é o único gênero por se constituir, e ainda inacabado. As forças criadoras dos gêneros agem sob os nossos olhos: o nascimento e a formação do gênero romanesco realizam-se sob a plena luz da História." (2002, p. 397)

${ }^{120}$ Em 1958, ao comentar os romances de Kafka, Adorno já diz: "Seus romances, se é que de fato eles ainda cabem nesse conceito, são a resposta antecipada a uma constituição do mundo na qual a atitude contemplativa tornou-se um sarcasmo sangrento, porque a permanente ameaça da catástrofe não permite mais a observação imparcial, e nem mesmo a imitação estética dessa situação.” (2003, p. 61, grifo meu)

${ }_{121}$ A discussão sobre as apropriações do gênero no contexto nacional específico da Argentina aparece em vários outros textos de Piglia, como "Novela y utopía" (2001a, p. 87-100).
} 
transformações no seio da tradição cultural ocidental ao longo do século $\mathrm{XX}^{122}$-, como analisar suas particularidades em contextos mais específicos - por exemplo, a literatura argentina. De todo modo, as abordagens não são necessariamente excludentes, já que o caso particular se situa em relação ao quadro mais amplo. Dito de outro modo, a abordagem de Piglia sobre certas características peculiares do romance na tradição literária argentina surgidas a partir de inúmeros processos de $\operatorname{assimilação~}^{123}$ - parte da observação de características mais gerais da literatura ocidental em seus processos de transformação, que, por sua vez, parecem atrair mais a reflexão crítica de Saer, por exemplo.

O aprofundamento da discussão sobre o gênero seguirá por todo o século XX e tratará tanto de supostas características perenes da narrativa romanesca como das que dela se irão configurando nos novos contextos. Entre as primeiras, parece estar o caráter pluriestilístico, plurilíngue e plurivocal do romance, apontado por Bakhtin já na década de 1930 (2002, p. 73), mas já mencionado por Luckács quinze anos antes (2009, p. 85):

A composição do romance é uma fusão paradoxal de componentes heterogêneos e descontínuos numa organicidade constantemente revogada. As relações que mantêm a coesão dos componentes abstratos são, em pureza abstrata, formais: eis porque o princípio unificador último tem de ser a ética da subjetividade criadora que se torna nítida no conteúdo.

Entretanto, depois, especialmente, das vanguardas artísticas das décadas de 1910 e 1920, as diferenças na narrativa romanesca em relação aos modelos do século XIX se

\footnotetext{
${ }^{122}$ O problema da definição e das transformações da narrativa, que segue vigente no século XXI, está presente já desde o início do século XX. A percepção de Eikhembaum é, já em 1925, a de que o romance do século XX ainda não se havia constituído como uma nova forma, um novo gênero, em relação ao romance do século XIX, mas que uma nova tradição na narrativa romanesca já surgia, diferenciando-se e da anterior e problematizando a forma do romance: "O desenvolvimento desse romance chegou a seu apogeu durante a década de 70 do século XIX; desde então, não nos libertamos dessa impressão de definitivo, cremos que não existe forma ou gênero novo na prosa literária. Entretanto, o romance desse tipo desagrega-se à nossa frente e diferencia-se. De um lado, cultivam-se as pequenas formas próximas da simples narração, de outro, encontramos memórias, relatos de viagens, correspondências, estudos de costumes [...]. Esses fenômenos, escondidos pelo desenvolvimento do romance e a inércia que ele provocou, reaparecem agora como uma nova tradição; a prosa contemporânea atualizou o problema da forma e também o problema da narração." (1971, p. 161)

${ }^{123}$ A presença da tradução e das citações - incluídas as más traduções e as citações equivocadas - na origem de muitos textos e clave na formação de muitos escritores argentinos será abordado por Piglia em diversos artigos, vários deles presentes em Crítica y ficción (2001a).
} 
acentuam e valores como o "princípio unificador da ética da subjetividade criadora" são postos em cheque. Como já aponta Adorno (2003, p. 61-2):

\begin{abstract}
Quando em Proust o comentário está de tal modo entrelaçado na ação que a distinção entre ambos desaparece, o narrador está atacando um componente fundamental de sua relação com o leitor: a distância estética. No romance tradicional, essa distância era fixa. Agora ela varia como as posições da câmara no cinema [...].O sujeito literário, quando se declara livre das convenções da representação do objeto, reconhece ao mesmo tempo a própria impotência, a supremacia do mundo das coisas, que reaparece em meio ao monólogo.
\end{abstract}

Os problemas de representação no romance a partir das vanguardas, no entanto, não se resumem à posição subjetiva do artista manifestada na obra e se ligam a vários outros fatores do novo contexto cultural e artístico, com as dificuldades adicionais relativas à representação artística literária, já que, “em contraste com a pintura, a emancipação do romance em relação ao objeto foi limitada pela linguagem, já que esta ainda o constrange à ficção do relato" (ADORNO, 2003, p. 56). Para Saer, ao mesmo tempo escritor de ficção e pensador da literatura, o problema da adequação literária à modernidade artística e as possibilidades de superação do relato aparecem, então, como questão incontornável (2006a, p. 23):

En los años cincuenta y sesenta, los teóricos del Nouveau Roman afirmaban que la novela era el único arte que, en el siglo XX, no había llevado a cabo la revolución vanguardista, a diferencia de la plástica, la música y la poesía, que desde hacía ya casi tres cuartos de siglo venían cumpliendo la suya.

A difícil adequação da narrativa à revolução promovida em outros campos artísticos ${ }^{124}$ não é problemática para Saer pelo mero desejo de alcançar um suposto "gesto vanguardista" em sua obra. Ela é fundamental a partir da reflexão sobre a narrativa que conclui com o esgotamento do modelo de romance encerrado por Flaubert com Bouvard et Pécuchet, segundo Saer (1997, p. 282-3), e a necessidade da busca de novas formas de expressão

\footnotetext{
${ }^{124}$ Ver, a este respeito, também ROSENFELD (2006, p. 80) e MENDILOW (1972, p. 55).
} 
narrativas. Uma das saídas que se encontram, então, para a "revolução" da forma do romance vem pela distorção ou demolição da representação das unidades de tempo e espaço na narrativa, o que, em última consequência, significa a superação de todas as convenções de representação formuladas nas tradições narrativas anteriores. Com relação à superação do romance burguês do século XIX, vem à tona, por exemplo, a discussão do "realismo" da representação literária, uma questão ainda hoje não superada ${ }^{125}$.

Para Adorno, no entanto, tal superação é um imperativo na narrativa moderna, já a partir, pelo menos, de fins dos anos 1950 (o trecho abaixo é extraído de "Posição do narrador no romance contemporâneo", de 1958) (2003, p. 57 e 60):

Se o romance quiser permanecer fiel à sua herança realista e dizer como realmente as coisas são, então ele precisa renunciar a um realismo que, na medida em que reproduz a fachada, apenas a auxilia na produção do engodo. [...] $\mathrm{O}$ romance tradicional, cuja ideia talvez se encarne de modo mais autêntico em Flaubert, deve ser comparado ao palco italiano do teatro burguês. Essa técnica era uma técnica de ilusão. [...] A nova reflexão é uma tomada de partido contra a mentira da representação, e na verdade contra o próprio narrador, que busca, como um atento comentador dos acontecimentos, corrigir sua inevitável perspectiva. (grifo do autor)

Nota-se aqui, mais uma vez, a influência de Adorno em Saer, que em "Narrathon", de 1973, trata das mesmas questões que o autor alemão e chega até a usar as mesmas imagens: "La narración tradicional no construye, refecciona. Novelas que hablan de fachadas no podrán tener otra consistencia y otro espesor que el de la apariencia de que hablan." (1997a, p. 151, grifo meu). Daí que, da especificação de Adorno em seu texto ao falar de um realismo, cheguemos às discussões de Saer sobre o vazio implícito neste conceito: "Realismo, en esos textos [del Nouveau Roman], no es más que una etiqueta, como si hubiese un solo realismo y una sola realidad. Realismo es una categoría tan subjetiva como modernidad." (1997a, p. 179).

\footnotetext{
${ }^{125}$ Mas já apontada, por exemplo, por Wayne Booth em 1961 (1980, p. 55-6).
} 
Por outro lado, autores como A. A. Mendilow vêm que o "efeito realista" do romance se desfaz mais pela evolução das posturas críticas em relação ao gênero do que por uma qualidade intrínseca deste que teria sido superada ${ }^{126}$, no que também coincide Saer (1997a, p. 179):

\begin{abstract}
¿Realismo es el de Dostoievski o el de Melville? ¿El de Balzac, el de Cervantes o el de Proust? ¿El de Faulkner? ¿El de Svevo? ¿El de Musil? ¿El de Gadda? ¿El de Pavese? ¿El de Joyce? Lo de Kafka, ¿qué es? ¿Acaso estos escritores creían en la identidad absoluta del significado y del referente? ¿Creían de verdad que sus novelas eran una representación mecánica del mundo?
\end{abstract}

Neste sentido, a posição de Mendilow e Saer reflete a de Bakhtin, que vê o que ele chama de enunciados complexos ou secundários os formados por outros, simples ou primários. O discurso literário - não só o literário, nem só o do romance, ainda que este, me parece, se adapte, em especial à tese -, então, constitui-se como um enunciado secundário, que se forma retrabalhando os enunciados primários - "reais", ligados à "vida cotidiana" (2010, p. 263-4):

Esses gêneros primários, que integram os complexos [romances, dramas, pesquisas científicas de toda espécie, os grandes gêneros publicísticos, etc.], aí se transformam e adquirem um caráter especial: perdem o vínculo com a realidade concreta e os enunciados reais alheios: por exemplo, a réplica do diálogo cotidiano ou da carta no romance, ao manterem a sua forma e o significado cotidiano apenas no plano do conteúdo romanesco, integram a realidade concreta apenas através do conjunto do romance, ou seja, como acontecimento artístico-literário e não da vida cotidiana.

\footnotetext{
${ }^{126}$ Em outras palavras, mesmo um romance de Balzac ou de Flaubert, lido hoje, não deverá ser considerado "realista", no sentido de representar uma "verdade em relação à vida": "Mais do que as outras, [as convenções mediais] se desfazem de qualquer reivindicação, no romance, da 'verdade em relação à vida'. Podem permitir apenas a interpretação altamente seletiva e individual de uma 'verdade da vida'; pois a apresentação do romancista não é apenas colorida pela sua personalidade e pelo alcance e profundidade de suas experiências particulares, mas, mais ainda, é limitada pela sua capacidade de veicular esta verdade apenas em palavras; em verdade, ele pode conceber apenas o que dela existe para si no plano verbal. [...] $\mathrm{O}$ romance, então, pelas limitações de seu meio, nunca pode atingir a realidade, a vida, a verdade ou qualquer outra dessas 'abstrações muito carregadas'." (MENDILOW, 1972, p. 56-7)
} 
Por este caminho, ainda quando não aborda diretamente o problema da representação literária, Piglia também participa da discussão sobre a narrativa no século XX ao concebê-la como um ponto de entrecruzamento de relatos sociais, por exemplo, em "Los relatos sociales" (2001a, p. 100-8) e "Novela y utopía" - "Me interesa cada vez más estudiar el lugar de la ficción en la sociedad porque me parece ese es el contexto mayor de la literatura." (2001a, p. 87-100). Em todo caso, chega-se à constatação de artificialidade e de ilusão de "realismo" na ficção como um fenômeno a ser observado. Para Saer, é preciso ter cuidado com as representações de "fachadas da realidade" travestidas de realismo; para Piglia, é necessário pensar, de certo modo, em sentido contrário: em como na realidade se constroem ficções.

Chega-se, então, à conclusão de que a prática da narrativa, tanto de Saer como de Piglia, passa por uma operação de desmascaramento das ilusões realistas, pela consciência da artificialidade no ato de escrever e pela vontade de narrar além da vontade de representação do real. Para Piglia, a partir de Macedônio Fernández: "No se trata de ver la presencia de la realidad en la ficción (realismo), sino de ver la presencia de la ficción en la realidad (utopía). [...] Contra la resignación del compromiso realista, el anarquismo macedoniano y su ironía." (2001a, p. 123) Para Saer, é preciso falar (1997a, p. 148):

[...] en tanto que ciego, a los demás, para que vean, no la realidad, o una realidad, sino más bien la ceguera que sufren y de la que, en la mayoría de los casos, no son conscientes más que a medias. La estructura de la novela ha de ser, a mi parecer, y para mí, en mi praxis, la estructura de esa posición incómoda de la consciencia en que la ha puesto, o ha venido poniendo, durante siglos, la opresión.

Mais uma vez, ressoarão nos escritores argentinos suas influências teóricas. Walter Benjamin, em “A crise do romance”, de 1930, já vê no romance uma superação da narrativa tradicional - a épica em todas as suas manifestações -, em seu caráter solitário, uma 
separação do povo e do mundo ${ }^{127}$. O romance, assim, dissocia-se do contato com a realidade mediado por uma convenção da linguagem e esta passa a ser, ela mesma, matéria para a reflexão na narrativa, como também o aponta Adorno (2003, p. 56):

O romance precisaria se concentrar naquilo de que não é possível dar conta por meio do relato. Só que, em contraste com a pintura, a emancipação do romance em relação ao objeto foi limitada pela linguagem, já que esta ainda o constrange à ficção do relato: Joyce foi coerente ao vincular a rebelião do romance contra o realismo a uma revolta contra a linguagem discursiva.

\section{Representação e gênero em duas práxis narrativas}

Depois de Arlt, Borges e Cortázar (mortos em 1942, 1986 e 1984, respectivamente), os argentinos Juan José Saer - nascido em 1937 - e Ricardo Piglia - nascido em 1941 formam parte de uma geração de escritores com uma espécie de desafio intelectual: superar a onipresença da obra de Borges e livrar-se das amarras do boom da literatura latino-americana, com seus traços fantásticos e pitorescos, seu exoticismo ao gosto europeu. Escrevendo a partir de fins dos anos sessenta e participando ativamente da cena intelectual do país, chegam à consagração crítica nos anos oitenta, colocando-se no centro do cânone literário e intelectual argentino do fim do século XX. Influenciados em sua formação pelo estruturalismo e o pósestruturalismo, as ideias da Escola de Frankfurt, a literatura norte-americana (especialmente Faulkner) e o noveau roman francês, tanto Saer como Piglia se encontram imersos em uma discussão sobre gênero e narrativa que já dura quase um século ${ }^{128}$, quando da publicação de La pesquisa (1992) e Plata quemada (1997), nos anos noventa.

\footnotetext{
127 “A matriz do romance é o indivíduo em sua solidão, o homem que não pode mais falar exemplarmente sobre suas preocupações, a quem ninguém pode dar conselhos, e que não sabe dar conselhos a ninguém. [...] A tradição oral, patrimônio da epopeia, nada tem em comum com o que constitui a substância do romance. O que distingue o romance de todas as outras formas de prosa - contos de fadas, sagas, provérbios, farsas - é que ele nem provem da tradição oral nem a alimenta. Essa característica o distingue, sobretudo, da narrativa, que representa, na prosa, o espírito épico em toda a sua pureza.” (1994, p. 54-5)

${ }^{128}$ E que, evidentemente, está presente na narrativa de um sem número de autores. Segundo Roland Bourneuf e Réal Ouellet, para muitos escritores, como os do nouveau romam, dos grupos Tel Quel ou Change, por exemplo:
} 
Como escritores, mas também como pensadores da literatura - ambos são professores universitários e escrevem também ensaios críticos -, as questões da relação entre narrativa e verdade, ficção e realidade, as convenções da representação literária "realista", os problemas da autonomia literária, são incontornáveis. É dentro desta reflexão sobre a literatura que tanto Piglia como Saer enfrentam-se com as questões de gênero literário e com a forte presença do gênero policial, ainda que com projetos estéticos e práxis narrativas bastante distintas.

Ricardo Piglia, apesar de ter dirigido, a partir de 1968, e editado a "Serie Negra", coleção de romances policiais norte-americanos publicada pela editora Tiempo Contemporâneo, afirma, em entrevista dada a Guillermo Mayr (2009b):

Leí a Fitzgerald, a Hemingway y a Faulkner, y también leí a Chandler y Hammett como formando parte de la narrativa norteamericana. Después empecé a difundir estas obras en esta colección como una manera, bastante clásica en los Estados Unidos, de trabajar como editor, como director de una colección literaria, y durante muchos años me gané la vida leyendo policiales y seleccionando títulos para traducir. Por lo tanto, no soy un escritor de policiales; he escrito solamente un cuento policial, que se llama "La loca y el relato del crimen", para un concurso de cuentos policiales [...], y es el único cuento de género que yo he escrito. El género está presente en mi literatura sin que yo escriba directamente narrativa policial.

De qualquer forma, ainda que o autor afirme não ser um "escritor de policiais", é patente a presença da estética do policial em narrativas como o romance Plata quemada, e o uso que se faz do gênero como "modelo de leitura" e estratégia narrativa. O gênero policial e o gênero romance, assim, se mesclam no uso de determinadas imagens, de modos de narrar, de construções de histórias por pistas, citações e, traduções, da conformação do texto como arquivo, como eco das vozes alheias e perdidas, as vozes do meio social que circulam e se chocam com os discursos dominantes.

\footnotetext{
"Escrever um romance constitui [...] um modo de conhecimento da linguagem, por vezes um pretexto para a teoria. Mas poder-se-á ainda, a propósito de destes textos experimentais, falar de romance, isto é, de um gênero literário identificável? Solicitado pela realidade ambiente e pela que trazemos em nós, dividido entre a criação do fictício e a investigação do real, não cessando de reproduzir formas fixas e de inventar o possível, o gênero é à imagem da palavra que o designa: flutuante e em perpétua expansão". (1976, p. 8-9)
} 
O grande problema da representação do real na literatura contemporânea encontra na ficção de Piglia uma resposta - ou, mais adequadamente, um meio de discussão - nesse procedimento, no fazer da narrativa mesma um artifício que desnuda a impossibilidade da representação literária "realista", oferecendo como alternativa um jogo de deciframentos dos discursos do outro - discursos estes sociais, políticos, literários, científicos, etc. Para Idelber Avelar, em "Para un Glosario de Ricardo Piglia” (2007):

Lo que podríamos llamar el problema de la crítica no es, en la obra de Piglia, un dato accidental, sino que entra en el proceso de confección de la obra misma. [...] Se trata también de que los intrincados modelos narrativos de su ficción mimetizan, se apropian de los gestos constitutivos de la crítica: selección, rastreo de pistas, abstracción, comparación, producción de antagonismos, voluntad paranoica de verdad. Todo esto entra en la obra de Piglia no como temas (es decir no se trata simplemente de abrir un "espacio" en la ficción para que se discutan problemas críticos, como haría la novela de tesis), sino que entran como procedimiento, como modo de construcción de la ficción misma.

Na mesma linha de raciocínio, Edgardo Berg, em "El relato ausente (Sobre la poética de Ricardo Piglia)" (FORNET, 2000), aponta que Piglia "ha logrado transformar en anécdota los problemas actuales de la narración, las relaciones entre la política y la escritura, y ha condensado, de un modo eficaz, los núcleos básicos de las narraciones sociales circulantes." (p. 65-6).

A práxis narrativa de Piglia, em Plata quemada (1997), se mostrará, então, coerente com o que o autor já vinha desenvolvendo em seus romances anteriores, Respiración artificial (1980) e La ciudad ausente (1992), nos usos da voz do outro, no embaralhamento dos relatos sociais que é o único meio de apreender, de alguma forma, o real pelo discurso. Assim, as cartas extraviadas de Respiración artificial, os contos produzidos pela máquina em La ciudad ausente, as vozes que ouve o Gaucho Dorda - e o radiotelegrafista Roque Pérez - em Plata quemada são os discursos que circulam na sociedade, e à margem dela, confrontados sempre com o discurso do Estado, o discurso único e oficial. Em entrevista de 1985, Piglia afirma que 
"hay una red de ficciones que constituyen el fundamento mismo de la sociedad, la novela trabaja esos relatos sociales, los reconstruye, les da forma. La pregunta en realidad sería: ¿de qué modo la novela reproduce y transforma las ficciones que se traman y circulan en una sociedad?” (2001a, p. 93) Quando o autor se faz esta pergunta, formula, ao mesmo tempo, uma poética para sua narrativa, que não se faz só sobre a voz do outro nos relatos sociais, mas também nos relatos da própria literatura - no fim das contas, relatos também sociais. Narrar e perguntar-se sobre o quê e como narrar é uma operação única que aparece nas conversas entre Renzi e Tardewski (em Respiración artificial), na máquina de Macedonio Fernández (em La ciudad ausente), no dinheiro e nos personagens marginais arltianos (em Plata quemada). Extrapolando a ficção, é uma operação que se repete até mesmo nos ensaios de Piglia, em suas entrevistas, em sua figura de autor exposta na mídia, nas aulas, no debate intelectual. É fora da ficção - ou da ficção "oficial”, dos contos e romances - onde também aparecem o mítico diário, as recordações da infância, o simbólico Ratliff - amigo da juventude que apresenta e simboliza toda a literatura norte-americana que vai atuar no fazer literário de Piglia. Voltando a Avelar (2007):

Una vez más, se muestra cómo el papel de la gran ficción no es reflejar la realidad (algo que Piglia viene diciendo hace casi cuarenta años), sino captar su núcleo de verdad, anticipar la siempre repetida y reinventada barbarie, ahora convertida en instrumento permanente de la guerra librada por los autoasignados defensores de lo que todavía tienen el desparpajo de llamar la civilización de la libertad.

Parece ser, na verdade, que a escrita de Piglia não se contenta em captar o núcleo de verdade da realidade na ficção, mas em expor o tanto de ficção que existe nos discursos que circulam no "mundo da realidade". Os personagens e fatos históricos "reais" que aparecem nos romances são tão parte da ficção nos romances de Piglia, como Emilio Renzi ou o dinheiro queimado. São todos, no fundo, discursos, ao mesmo tempo reais e irreais, atuantes no mundo palpável e nas tramas das narrativas. O uso do gênero policial dentro destas 
narrativas é um meio de transitar por elas, é uma forma de se escrever, mas principalmente de se ler. Em ensaio de Formas breves, o próprio Piglia afirma (2004a, p. 57):

É o grande gênero moderno; inventado por Poe em 1843, inundou o mundo contemporâneo. Hoje encaramos o mundo com base nesse gênero, hoje vemos a realidade sob a forma do crime, como dizia Bertolt Brecht. A relação entre a lei e a verdade é constitutiva do gênero, que é bastante popular, como era a tragédia. A exemplo dos grandes gêneros literários, o policial foi capaz de discutir o mesmo que discute a sociedade, mas em outro registro. É isto o que faz a literatura: discute a mesma coisa de outra maneira. O que é um delito, o que é um criminoso, o que é a lei? Discute o mesmo que discute a sociedade, mas de outra maneira.

Juan José Saer, por sua vez, desenvolve em sua narrativa outras estratégias para abordar o problema da representação na ficção literária e outra relação com o gênero. Ainda que não ataque propriamente o gênero policial em si, mostra-se sempre crítico e preocupado com o fato das classificações genéricas poderem ser entendidas e tomadas, por exemplo, como um mecanismo de controle do mercado, como afirma no ensaio "La novela" (1997a, p. 129-30): "Desde un punto de vista industrial, el género, por ejemplo, denota el carácter del producto, y le asegura de antemano al lector, es decir al comprador, que ciertas convenciones de legibilidad y de representación serán respetadas". Em "Una literatura sin atributos", também presente em El concepto de ficción a ideia reaparece de maneira parecida (1997a, p. 274-5):

Es así como ciertas designaciones que deberían ser simplemente informativas y secundarias se convierten por el solo hecho de existir, en categorías estéticas. [...]. La mayoría de los autores - a sabiendas o no - cae en la trampa de esta sobredeterminación, actuando y escribiendo conforme a las expectativas del público (por no decir, más crudamente, del mercado). [...] [L]os grandes escritores latinoamericanos del siglo XX [...] poseen en sus escritos un elemento que no se encuentra más que en los textos mayores de la literatura moderna: la voluntad de construir una obra personal, un discurso único [...]. 
Ainda assim, Saer assume o risco, por assim dizer, de confrontar-se em La pesquisa com o gênero policial e tentar adapta-lo à "sua maneira", continuando a produzir sua literatura pessoal e única. Se o gênero, em Piglia, funciona como estratégia para a narrativa e a leitura dos relatos sociais que se cruzam na ficção, para Saer o gênero é mais uma estratégia na busca da confecção de um discurso único, do discurso do autor (SAER, 1997a, p. 252-3):

\begin{abstract}
Es necesario considerar la literatura policial desde dentro, no desde afuera, si se quiere entender la singularidad artística de algunos de sus autores y ver con claridad las modificaciones creadoras que introducen en el género. [...] La [objeción] fundamental sería que la novela de género, policial en este caso, trabaja con estructuras narrativas ya consolidadas y, por lo tanto, no creadoras. Esta opinión, que lleva implícita una actitud vanguardista ante la narración, es válida sólo a medias: admitida una serie de convenciones narrativas, el valor de una obra puede residir en la utilización de esas convenciones para aportar resultados poéticos desde su interior.
\end{abstract}

Para Saer, então, o gênero pode servir como ponto de partida para o desenvolvimento da poética individual do autor que sempre busca - em sua própria práxis narrativa e nas de outros escritores que valoriza e admira. Por isto, a preocupação de Saer em La pesquisa segundo o expresso em artigo de La narración-objeto - era que "el placer de escribir una novela policial debía adaptarse en primer lugar a mi propia 'manera' narrativa”. (1999, p. 159-160) Esta "maneira" narrativa - que Julio Premat (2009) também chama de "cadência" ou "ritmo" - é a própria práxis construída pelo autor e posta em funcionamento tanto em $L a$ pesquisa (1994), como em Nadie nada nunca (1980) ou Glosa (1985).

Esta práxis narrativa vem, ao longo dos anos, sendo estudada por inúmeros $\operatorname{críticos}^{129}$ e alguns de seus traços parecem ir se destacando pela frequência com que surgem na análise e

\footnotetext{
${ }^{129}$ Ver, por exemplo na bibliografia deste trabalho: de Julio Premat, Héroes sin atributos (2009) e La dicha de Saturno (2002); de Jorgelina Corbatta, Juan José Saer: arte poética y práctica literaria (2005); a edição especial de Crítica cultural = Cultural Critique, dedicada a Saer, organizada por Liliana Reales, Julio Premat e Juan Carlos Mondragón, com artigos de Sarlo, Gramuglio, Abatte, Scavino, Premat e Mondragón, entre outros; o artigo "El entenado: tiempo y representación", de Florencia Garramuño, em Genealogías culturales Argentina, Brasil y Uruguay en la novela contemporánea (1998); e os artigos de Florencia Abbate, "No existe el optimismo en la buena literatura' (entrevista a Juan José Saer)” e de Dardo Scavino, "El vacío, las nubes y la lengua. Una introducción a Glosa de Saer", ambos em De Alfonsín al menemato 1983-2001: literatura argentina siglo $X X$, compilação de artigos organizada por David Viñas (2010).
} 
leituras da obra de Saer, como as discussões sobre os gêneros na narrativa - e a validade da categoria "romance" na literatura do século $\mathrm{XX}-$, o caráter autorreferencial da literatura, ou os desafios da representação literária ${ }^{130}$. Os traços recorrentes na poética saeriana, por fim, são amarrados no que Premat chama de "cadência" ou "ritmo" e o próprio autor de "maneira narrativa". É desta unidade de elementos - simbolizada também pela noção de "lugar", da "zona" saeriana, outro conceito sempre presente na crítica e ressaltado pelo próprio escritor que Saer parte na busca de uma escritura original, como afirma em uma entrevista a Florencia Abbate: "Yo siempre intenté utilizar en cada novela una forma distinta, siempre he tratado de no repetirme. Creo que la forma novelística hay que renovarla para que siga existiendo." (2010, p. 91) O uso do gênero policial, portanto, é uma possibilidade dentro da práxis narrativa de Saer, tanto quanto o é na de Piglia, ainda que esse uso se dê de maneiras diversas respeitando as feições de cada poética, de cada concepção estética e literária. Para Julio Premat, a comparação ocorre nos seguintes termos (2009, p. 203-4):

\begin{abstract}
La posición de Piglia [...] es contraria, en alguna medida, a la de Saer. Saer intenta, como vimos, borrar las huellas, afirmar una autonomía, delimitar un espacio - un lugar - de singularidad plena. Píglía, al contrario, se sitúa exacerbadamente en una actitud de lector: lector de novela policial, de Borges, de Macedonio, de Walsh, de Arlt, intensificando algunos rasgos de esos textos y figuras como manera de llegar, por el camino de una repetición deformadora y hasta de una falsificación multiforme, a una versión personal, a una singularidad. [...] Piglia retoma la idea de la literatura o de la lectura como fuente de la creación, mientras Saer pone en el origen de la literatura la pulsión, lo secretamente íntimo, lo único que, en nuestra cultura, sería reacio a lo ya escrito (aunque lo pulsional pueda irrumpir, de la mano de la locura, en Piglia, y Saer lleve a cabo sofisticadas operaciones de lectura y reescritura).
\end{abstract}

\footnotetext{
${ }^{130}$ Um dos capítulos de Juan José Saer: arte poética y práctica literaria, de Corbatta, por exemplo, se intitula "Algunas notas sobre la 'praxis poética' de Juan José Saer" (2005, p. 33-45) e ressalta, em três apartados: (I) a questão de gênero (contrastes e distinções entre os conceitos de "novela" e "narrativa"); (II) o discurso sobre o texto dentro do texto (a literatura autorreferencial e autorreflexiva); e (III) o problema do realismo (ou, mais profundamente, o problema da representação do real na literatura). Um contraponto a isto aparece em "El lugar de Saer", de Gramuglio (REALES, L.; PREMAT, J.; MONDRAGÓN, J.C., 2006, p. 33-64), nos apartados (I) "Vueltas de tuerca sobre la narración" e "El relato amenazado"; (II) “Literatura sobre literatura?”; e (III) "La construcción del lugar" e "Bastaría entender un objeto".
} 
Os contrastes entre os dois escritores, ao mesmo tempo em que os diferencia em suas poéticas, os aproxima nos paradoxos gerados pelas propostas de escritura: a busca obsessiva e paranoica pela "verdade" na ficção de Piglia produz uma confusão de vozes, versões que nunca se configuram como a verdade buscada; o centro de que pulsa a ficção de $\operatorname{Saer}^{131}$ é um lugar em que a unidade tem que se formar a partir de diversas formas, sempre em movimento e em mutação. Quando Carlos Fuentes se pergunta no artigo “O romance morreu?” (2007, p. 9-33) "Que pode dizer o romance que não se pode dizer de outra maneira?", é possível, pela leitura de Juan José Saer e de Ricardo Piglia - e de La pesquisa e Plata quemada - encontrar, mais do que respostas, um exercício de reflexão sobre o gênero, a literatura e a arte. A partir das grandes questões modernas da representação da realidade, as relações entre arte, cultura, história e política, a circulação de discursos na sociedade e a individualidade e originalidade do artista e sua obra, tenta-se dizer o que não se pode dizer de nenhum outro modo. Assim, o romance como um meio de circulação dos discursos sociais, para Piglia, deixa escapar as vozes que se confrontam com os discursos oficiais. Para Saer, é a busca incessante pelas novas formas que transformam o discurso romanesco que pode "formalizar algo nuevo que pueda traer consigo, finalmente, un sentido.” (1997a, p. 146).

\subsection{Saer e Piglia em uma tradição literária}

Ainda que os romances policiais de Saer e Piglia se encontrem no escopo das práxis narrativas únicas e originais de seus autores, há contextos maiores em que estas se inserem, sejam eles o de uma literatura nacional e sua tradição, o da sociedade vista de um ponto de vista sociopolítico ou o de uma estética da época em que são produzidas. Faz-se necessário,

\footnotetext{
131 "Narrar no es una operación de la inteligencia sola: es el cuerpo entero el que la realiza. Y la inteligencia no ocupa, en el todo, más que un lugar reducido. El medio natural de la narración es la somnolencia. En ese río espeso, la inteligencia, la razón, se abren a duras penas un camino, siempre fragmentario, tortuoso, arduo, entre las olas confusas de lo que James llamó the strange irregular rhythm of life." (SAER, 1997a, p. 155, grifos do autor)
} 
portanto, encontrar a coerência estética dentro de um projeto literário desenvolvido por dois escritores desde a década de sessenta e que, já nos anos noventa, rende dois romances de gênero policial. Como La pesquisa e Plata quemada se inserem em uma literatura autoral e em um contexto contemporâneo? Como dialogam com a questão do valor e dos gêneros populares na perspectiva de seus autores? Como o desenvolvimento de duas poéticas narrativas que tanto destaque recebem em seu contexto literário nacional se manifesta por meio dos romances? Como se articulam neles as tensões atuantes na dinâmica da literatura argentina $?^{132}$ Da realização particular e única de um texto relacionado a um gênero, o que se deve buscar é o entendimento maior de uma concepção do fazer literário de seu autor, da qual o texto é, ao mesmo tempo, fruto e origem. Em palavras de Leonor Arfuch, "es por el discurso y no meramente a través del discurso, por lo que se lucha." (2008, p. 95)

\section{O policial: discussões de valor, mercado e autonomia literária}

Um dos contextos em que se inserem La pesquisa e Plata quemada é o da posição destes romances - relacionados a um gênero comumente associado à cultura de massa e à "baixa literatura" - no conjunto da obra de dois escritores já canônicos e associados à "alta literatura" - autoral, única, problematizada. Com tudo o que apresenta de complexidade as discussões destes conceitos, as discussões entre "alta" e "baixa" literatura, de qualquer maneira, não podem ficar à margem das reflexões sobre o gênero literário, especialmente ao se tratar, como neste trabalho, do gênero policial e de escritores como Saer e Piglia.

Para ambos os escritores a utilização dos gêneros no romance é uma questão a ser pensada com cuidado. Para Saer, é possível partir das convenções narrativas e chegar a

132 A respeito de algumas destas tensões - realismo/escritura "pura"; centro/periferia; nacionalismo/estrangeirismo - escreve, por exemplo Noé Jitrik "Entre el corte y la continuidad: hacia una escritura crítica" (2002), sobre El limonero real, de Saer; e “"En las manos de Borges el corazón de Arlt", sobre Nombre falso, de Piglia, artigo publicado no volumen dedicado a este organizado por Jorge Fornet (2000, p. 8791). 
resultados poéticos satisfatórios, transgredindo-as a partir de seu interior (SAER, 1997a, p. 252-3). O cuidado, porém, com as associações dos gêneros com a indústria cultural e com fórmulas imutáveis - problemáticas e potencialmente limitadoras de suas qualidades artísticas - está sempre presente: “[L]as reglas económicas y retóricas del género [...] son normas que exigen imperiosamente la transgresión" (SAER, 1997a, p. 131). Piglia tampouco deixa de manifestar suas preocupações com os fenômenos da cultura de massas e da indústria cultural $^{133}$, nem com as categorias estéticas estanques ${ }^{134}$, além de também coincidir com Saer em uma ideia de transgressão dentro do gênero - no caso de Piglia, ao usar o policial como modelo de relato. Talvez a diferença mais significativa entre os dois autores seja a associação menos incisiva que faz Piglia entre os gêneros e os problemas da literatura de massas, preferindo, no caso do policial, ou ao menos de parte da literatura considerada policial, ressaltar com mais naturalidade, sua inserção em um conceito de "grande literatura" - "Leí a Fitzgerald, a Hemingway y a Faulkner, y también leí a Chandler y Hammett como formando parte de la narrativa norteamericana." (PIGLIA, 2009b)

Considerando-se que se, em linhas gerais, na "literatura artística" não se pode ou, ao menos, parece pouco produtiva a tentativa de se enquadrar obras de arte em gêneros prédefinidos - ainda que as "grandes obras artísticas" também possam se relacionar com os gêneros pela sua transgressão -, na "literatura de massa" o gênero impera. Neste caso, a indústria editorial demanda dos produtores - escritores - sempre produtos - livros facilmente identificáveis e prontos para serem devorados pelos consumidores - leitores -, em uma lógica de mercado. Para Todorov, em “Tipologia do romance policial” (2003a, p. 65):

\footnotetext{
133 "Me parece que lo que hay es una manipulación de la literatura por la cultura de masas, que produce una serie de efectos nuevos, que los editores están haciendo transas con la cultura de masas y que los grandes multimedios, como se dice ahora, también compran editoriales. Entonces creo que, en verdad, estamos enfrentando el mismo problema que enfrentó la vanguardia desde su origen, qué hacemos con la cultura de masas, pero ahora en otra dimensión, en una dimensión macro [...] (PIGLIA, 1997a, p. 181)

134 "Pareciera que la categoría más segura es un cierto estándar estilístico que un sector acepta como 'buenas escrituras' y por tanto organiza el valor. El problema es que esos textos se parecen todos entre sí y son intercambiables." (PIGLIA, 1997a, p. 147)
} 
Geralmente, a obra-prima literária não se encaixa em nenhum gênero, a não ser em seu próprio; mas a obra-prima da literatura de massa é precisamente o livro que melhor se inscreve em seu gênero. $O$ romance policial tem suas normas; fazer "melhor" do que elas exigem é ao mesmo tempo fazer pior: quem quiser "embelezar" o romance policial, faz "literatura" e não romance policial. O romance policial por excelência não é aquele que transgride as regras do gênero, mas aquele que a elas se conforma. [...] Caso os gêneros da literatura popular fossem bem descritos, não se poderia mais falar de suas obras-primas: daria na mesma; o melhor romance será aquele sobre o qual nada se tem a dizer.

Esta análise, bastante rígida, de Todorov, apresenta alguns problemas quando vincula o gênero inexoravelmente à literatura de massas e presa a fórmulas incontornáveis, separando de maneira irreconciliável a literatura artística dos gêneros da literatura popular. Esta é, como vimos anteriormente, uma maneira de se conceber o gênero - como categoria da indústria cultural -, mas não é a única. Tomá-la como definitiva implica em um conceito de valor temerário - "a obra-prima literária não se encaixa em nenhum gênero" - e um pensamento tautológico - o policial será sempre literariamente "ruim"; se for bom, não será policial, mas "literatura". Curiosamente, em Formas breves, Piglia afirma: "Cumpre dizer que no romance, desde Joyce, a forma 'obra-prima', converteu-se num gênero que tem suas convenções, suas fórmulas e suas linhas temáticas tão definidas e estereotipadas como as que se encontram, por exemplo, no romance policial." (2004a, p. 82). Em outras palavras, um grande perigo na contraposição feita por Todorov entre "romance policial" e "obra-prima literária" é o de que, ao isolar o policial da "alta" literatura, atribuindo ao gênero convenções rígidas e intransponíveis, acaba por criar outras tão estanques quanto para a literatura considerada de alta qualidade artística. Por isto é preciso analisar o diálogo do gênero com as obras autorais de Saer e Piglia de maneira mais ampla e aberta.

Ana María Amar Sánchez, em "Vínculos, usos y traiciones. La cuestión teórica” (2000) faz uma interessante discussão sobre a conceituação de "alta literatura" ou "literatura artística" e "baixa literatura" ou "literatura de massa ou popular", ressaltando a ideia presente na citação de Chartier que abre o texto: "La cultura popular es una categoría académica". Em 
outras palavras, a autora aponta as dificuldades em se definir e estabelecer as relações entre culturas "alta" e "baixa", destacando também como são maioria os estudos em torno dos efeitos ideológicos das formulas narrativas da literatura popular ou de massa e raros os que se dedicam a estudar as relações desta com a denominada "alta cultura". Por outro lado, ressaltando o caráter contingente do conceito de valor, Idelber Avelar afirma que (2009, p. 138):

Carece de qualquer fundamentação filosófica a ideia de que a viabilidade do conceito de valor estético dependa da aceitação de uma diferença essencial, imanente entre o valor das obras agrupadas sob a rubrica da arte erudita e o valor daquelas que convencionamos chamar de populares ou massivas.

Em resumo, vê-se o quão externas à literatura em si podem ser as categorizações muitas vezes feitas sobre bases ideológicas - que elevam ou rebaixam determinadas obras, autores e gêneros em relação aos cânones da alta cultura ${ }^{135}$. Ainda assim, não se pode negligenciar, por exemplo, a preocupação de Saer com certo relativismo - que ele vê ideologicamente fomentado pelo conceito de pós-modernismo - que concebe que Juan Carlos Onetti e Isabel Allende são igualmente romancistas, não se estabelecendo as enormes diferenças entre ambos. ("Posmodernos y afines", 2005, p. 9-16) ${ }^{136}$. Ou a de Jorge Volpi, de que o "romance-praga", o best-seller que repete fórmulas à exaustão, esgote o romance como forma de expressão artística - fato pelo qual seria necessário “combatir por la novela compleja, aquella que no se rinde a la imitación, que desafía las convenciones, que busca superarse a sí misma.” (2008, p. 37). Como conciliar, então, o gênero e o romance complexo?

\footnotetext{
135 Amar Sánchez (2000) cita os casos de Roberto Arlt e Manuel Puig,,autores a princípio marginais e que passam a ocupar, com o tempo, um lugar nesse cânon. Avelar (2009), por sua vez, menciona o "rebaixamento" de valor que sofre Julio Cortázar no âmbito da literatura argentina contemporânea.

${ }^{136}$ Em sentido parecido, Piglia também faz uma crítica aos "pós-modernos" - conceito que o próprio autor põe entre aspas -, quando estes aplicam os conceitos da cultura de massas a outros campos da sociedade (1997a, p. 211).
} 
Uma saída é repensar o conceito de gênero, desvencilhando-o da lógica do mercado literário e pensando-o dentro de uma lógica da criação literária ${ }^{137}$. É possível - ainda que não seja a única alternativa - definir o gênero policial, por exemplo, a partir do que o torna maleável à criação artística tomando-se dois traços distintivos fundamentais: o de que o gênero é uma narrativa que articula socialmente na ficção os conceitos de crime, lei e verdade $^{138}$ e o de que é uma narrativa sobre a narrativa - não se narra o "fato/crime", narra-se o raciocínio que se desenvolve sobre ele. É a partir, justamente, desta concepção do policial que se pode fazer uma série de considerações sobre a utilização do gênero nas escrituras de Juan José Saer e Ricardo Piglia.

Para Ana María Amar Sánchez, é justamente a partir da flexibilidade e das possibilidades de se ir além das fórmulas que a história do gênero policial se desenvolve na América Latina (2000, p. 46):

Las versiones latinoamericanas del género contradicen a los detractores que lo acusan de ser una máquina de repetición de la fórmula empobrecedora y "alienante". [...] Una novela policial sería siempre una manifestación particular, con pocas variaciones, de la fórmula; ésta, a su vez, es el requisito indispensable de una literatura de masas destinada a la evasión de un lector adicto que solo desea reencontrarse con lo ya conocido y realimentar sus fantasías de un mundo más interesante.

Quando Saer se propõe a usar o gênero policial em La pesquisa, então, tem que matizar sua declaração de que os gêneros cumprem o mesmo papel que a embalagem invariável de uma marca de café: "su finalidad es permitirle al cliente identificar claramente el

\footnotetext{
${ }^{137}$ Já em 1925, Eikhembaum propõe que "as condições locais ou históricas criam diferentes variações, mas o próprio processo guarda esta ação enquanto lei evolutiva; a interpretação séria de uma efabulação feita cuidadosa e detalhadamente dá lugar à ironia, à brincadeira e ao pastiche; as ligações que servem para motivar a presença de uma cena tornam-se mais fracas e perceptíveis, puramente convencionais; o próprio autor vem ao primeiro plano e destrói frequentemente a ilusão de autenticidade e seriedade; a construção do tema torna-se um jogo com a fábula transformada em adivinhação ou anedota. Assim se produz a regeneração do gênero: ele encontra novas possibilidades e novas formas." (1971, p. 166)

${ }^{138}$ Como ressalta o já citado Daniel Link (2002, p. 73).
} 
producto que está buscando." (2006a, p. 12) E, na verdade, é o que ele faz no texto sobre o romance que aparece em La narración-objeto (1999, p. 160):

Yo creo que la práctica ingenua de un género, sin plantearse su carácter relativo, es siempre menos fecunda que su utilización consciente y renovadora. Esto, que es válido para la novela policial, lo es también para la epopeya o para cualquier otro género. Detrás de la aparente inmutabilidad de los géneros tradicionales, hay un mar de fondo en constante transformación.

No entanto, trabalhar com o gênero pela transgressão e pela renovação, apresenta também seus desafios. Jorge Volpi, que ataca a repetição e a fórmula do que chama romancepraga ${ }^{139}$, concede, por exemplo, que "la utilización de los recursos de las novelas de género significó una bocanada de aire fresco frente a la experimentación formal de los años sesenta" (2008, p. 35-6). Neste sentido, é possível acudir à ideia de Boris Groys de que a inovação na arte moderna ocorre antes nos deslocamentos de espaço do que no tempo. Assim, o deslocamento do gênero policial da literatura de massas para as escritas autorais constitui uma operação em direção do novo (GROYS, 2013, p. 28):

$\mathrm{El}$ arte tradicional funcionaba en el nivel de la forma. El arte contemporáneo funciona en el nivel del contexto, del marco de referencia, del fondo o de una nueva interpretación teórica. Pero el objetivo es siempre el mismo: crear un contraste entre forma y trasfondo histórico para hacer que la forma se vea diferente y nueva.

Ainda segundo Groys, repercutindo Kierkegaard, o novo só se constrói verdadeiramente pela identidade - uma "diferença sem diferença" ou uma "diferença além da diferença" -, e não pela alteridade - uma diferença reconhecida e que, portanto, não pode ser considerada realmente como o novo: "La obra de arte nueva se verá realmente nueva y viva sólo si se asemeja, en un cierto sentido, a cualquier otra cosa común o profana, o a cualquier

\footnotetext{
139 "A fuerza de repetir hasta el cansancio las mismas estructuras, de exacerbar artimañas y machacar temas, el género sentimental y policíaco, los novelistas destruyeron su forma de vida." (VOLPI: 2008, p. 15)
} 
otro producto ordinario de la cultura popular." (2013, p. 17). Voltando, então, a Volpi, é possível pensar melhor em sua advertência quanto ao uso indiscriminado do gênero, que "se ha convertido en una carga", com a criação de novas fórmulas, resultando em algo que ele denomina "el manierismo de lo policíaco, lo negro, lo fantástico y lo folletinesco" 140 , que tiram espaço das narrativas mais experimentais e ambiciosas (2008, p. 35-6). Essa repetição de procedimentos no trabalho com os gêneros populares, só ressaltando uma suposta diferença com relação aos exemplares mais tradicionais desses mesmos gêneros, se assemelharia, então, ao exemplo do carro novo comparado ao modelo mais antigo, dado por Groys. Tanto o carro como o gênero permanecem em suas funções já conhecidas, não há nenhum deslocamento do lugar que cada um ocupa, na sociedade ou na literatura, e não há, portanto, o novo de fato. Assim, é preciso ir além da operação de se incluir ideias ou discussões filosóficas - ou pseudofilosóficas - em tramas policiais, no mais, absolutamente convencionais. É preciso ir, por exemplo, à base da narrativa sobre a narrativa presente no gênero - traço profundamente moderno no sentido de apresentar a literatura desnudada em sua autonomia. Deste modo é possível aproximar a narrativa “[d]aquele caráter de brincadeira elevada que ela possuía antes de se meter a representar, com a ingenuidade da não-ingenuidade, a aparência como algo rigorosamente verdadeiro", nas palavras de Adorno (2003, p. 61).

Por fim, o gesto moderno do policial ao ressaltar a autonomia do texto literário não cai na alienação da arte e do artista em relação à sociedade por, ao menos, dois motivos que se complementam. Em primeiro lugar, pela superação da dicotomia estreita entre uma arte “engajada” e uma arte "autônoma”. Na visão de Marcos Siscar (2010, p. 10):

A reivindicação de uma perspectiva singular, traduzida como aspiração à "autonomia" dita estética, nesse sentido, designa muito menos o sintoma de um escapismo social do poeta, como normalmente é vista, do que uma

\footnotetext{
${ }^{140}$ No artigo sobre La pesquisa publicado em La narración-objeto, Saer também alerta para o convencional que ele buscou evitar - do que ele chama "policial metafísico", seu equivalente ao maneirismo do gênero de que fala Volpi. (SAER, 1999, p. 159)
} 
resultante discursiva na qual se explicita (ou se dramatiza, isto é, se dá a entender, pelos expedientes da retórica e do phatos) um certo saber sobre o real - um saber que frequentemente coloca em primeiro plano a violência de sua exclusão e o sentido de seus fins. Em outras palavras, a autonomia desejada pela poesia não é aquela que a isolaria da realidade intolerável, mas aquela que de fato lhe fornece os recursos para carregar ou suportar os paradoxos de sua inscrição na realidade, atribuindo-lhe a condição de discurso histórico que denuncia, inclusive, as ficções paradisíacas da cultura como identidade entre forma e experiência.

Assim, a defesa intransigente que faz Saer da autonomia literária - no sentido de propor, ao menos para si mesmo, uma literatura sem "ningún compromiso previo con nadie ni con nada y, sobre todo, con ninguna teoría" (1997a, p. 152-3) - não se confunde nunca com “alienação" ou falta de compromisso político, mesmo que tal autonomia possa conduzir a uma escrita “difícil” e até mesmo hermética (1997a, p. 157-8):

La crítica sociológica de la vanguardia pretende que el hermetismo es un modo de valorizar, por la rareza, en el mercado, el producto. Hay parte de verdad en eso: pero si admitiéramos ese argumento como una verdad absoluta estaríamos, contemporáneamente, admitiendo la alienación absoluta y borrando, de ese modo, la dialéctica histórica. La alienación, sin embargo, no está en la literatura que la refleja, sino en la que la escamotea, no está en la división vivida como división, sino en la división vivida como integridad. No está en Macedonio Fernández que teoriza, arduamente, la imposibilidad de narrar, sino en Vargas Llosa, que dedica trescientas páginas a describir la vida de un colegio militar, confundiendo la crítica liberal a un aspecto de la superestructura con una crítica de lo real. Es abriendo grietas en la falsa totalidad, la cual no pudiendo ser más que imaginaria no puede ser más que alienación e ideología, que la narración destruirá esa escarcha convencional que se pretende hacer pasar por una realidad unívoca.

Na mesma linha de raciocínio parece seguir Piglia, que crê que a ficção "tiene otra manera de trabajar la política que cuando se la escribe con una óptica 'realista' o ‘periodística'." (2001a, p. 113). De maneira análoga a que Saer toma o exemplo de Macedonio Fernández, Piglia usa a figura de Roberto Arlt para ilustrar sua ideia (2001a, p. 113-4): 
Si se piensa en Roberto Arlt, se ve que Arlt es la verdadera literatura política. Un tipo que nunca hablaba de Yrigoyen, que nunca hablaba de lo inmediato, que nunca hablaba de lo que estaba pasando. $\mathrm{Y}$ en su tiempo había, claro, muchos otros que estaban escribiendo novelas simultáneamente con él, que hablaban de las huelgas y de los conflictos y los contenidos inmediatos; pero fue Arlt el que captó el núcleo secreto de la política argentina, y escribió una novela que se lee hoy y parece que se escribió ayer. Eso es la literatura política. Eso es la ficción política. Capta el núcleo secreto de una sociedad. Funciona, digamos así, transformando esos elementos que son los núcleos verdaderos, los núcleos de interpretación.

Se, então, a autonomia da literatura é justamente a que a faz possível em uma realidade que, esta sim, é alienante e opressora, o uso do gênero policial fornece a oportunidade para discutir essa realidade apresentada nas formas do crime, da lei e da verdade. O discurso literário pode jogar luz nos discursos sociais e ideológicos que circulam na realidade. Abordando o caso específico de Rodolfo Walsh, por exemplo, Daniel Link, propõe que, apesar de uma marca de anti-intelectualismo presente nos escritores dos anos sessenta, o que ocorre é justamente o contrário: "es la propia dinámica de la literatura (en su autonomía) la que arroja a los intelectuales latinoamericanos en las tenebrosas aguas de la política.” (1998, p. 135)

O outro motivo pelo qual se pode pensar uma escritura dentro do gênero policial que não é, por obrigação, alienante, é justamente a permeabilidade do gênero aos discursos sociais. É possível, assim, inverter outro parâmetro: em lugar de fazer da fórmula do policial um instrumento de alienação, é possível fazer da transgressão do gênero uma ferramenta de reflexão, experimentação e complexidade. Voltando a Siscar (2010, p. 38-9):

Embora a literatura faça parte do mercado (antes mesmo da concorrência capitalista), de uma certa concorrência cultural e, por isso, não prescinda da formação de profissionais e de estratégias de divulgação (que hoje chamamos "publicidade", mas que inclui igualmente a chamada "crítica literária"), é preciso não perder de vista o que ela tem de heterogêneo a essa lógica, não por estar fora dela, mas pelo fato de dramatizar as suas contradições. Até por isso, ela se beneficia decisivamente da formação crítica de seus explicadores, da presença constante de um metadiscurso que seja capaz de levar adiante sua prática de pensamento. [...] Creio que não há como responder à injunção que nos é dirigida pela literatura sem levar em 
conta, como disse, aquilo que nela há de heterogêneo à setorização, aquilo que dramatiza o conflito entre sua especificidade e seu sentido geral, entre seu "lugar no mercado" e a dissimetria das trocas, entre a moral da equivalência geral entre os indivíduos e a possibilidade de dizer tudo (de dizer o impossível, de admitir o inadmissível). Responder à injunção da literatura significa, por isso, não exatamente contrapor-se ao "mercado", à interação e à troca, mas inserir-se nessas trocas de modo a denunciar seus efeitos de censura, mantendo no horizonte uma ideia de democracia por vir.

O uso do policial pode transgredir as convenções do gênero quando busca, pelo deslocamento de seus lugares tradicionais, a "diferença além da diferença" que constitui o verdadeiramente novo - na definição de Groys. Se isto vale em termos da lógica interna do texto, também vale na relação da literatura com a sociedade e mundo - se é que tal distinção é possível. É o que propõe Saer quando afirma que as regras econômicas e retóricas do gênero "exigen imperiosamente la transgresión" (SAER, 1997a, p. 131, grifo meu). A mesma necessidade de atuar na literatura, que é também um mercado, mantendo uma coerência ao mesmo tempo política e estética aparece também em Piglia (2001a, p. 181):

¿qué pasa hoy con un escritor que trabaja y quiere publicar sus libros en medio de un proceso de concentración, con editoriales multinacionales muy poderosas, y qué posibilidades de negociación existen? [...] los premios, obviamente, son una manifestación pura de la lógica del mercado, realizan directamente lo que el mercado insinúa, establecen una jerarquía fija, deciden que un libra es "mejor" que otro, y en ese sentido son la antítesis de la literatura, que es un espacio fluido, sin poder, donde los textos entran y salen de la lectura sin ningún sistema que los legisle, y a la vez son un modo de circulación específico, una forma particular de ampliar la circulación. Y eso sucede habitualmente cuando uno publica un libro, que el texto circula en un ámbito que obedece a otra lógica y el escritor tiene que entrar y salir, por lo menos yo tengo esa posición, la posición de una guerra de posiciones, digamos, moverse en distintos circuitos.

A posição relativa do autor que atua em um mercado sem submeter-se a ele pode ser, de maneira análoga, a mesma da narrativa policial que não se submete às regras do gênero, mas busca uma transgressão que resulte na escrita singular de seu autor. La pesquisa e Plata quemada, então, podem ser lidas como romances policiais que atuam dentro do gênero sem pertencer a ele e refletindo, antes que tudo, as poéticas de seus autores. 


\section{Formações e transformações}

As datas de publicação de La pesquisa (1994) e Plata quemada (1997) situam ambos os romances em um período em que seus autores já haviam alcançado um reconhecimento crítico depois de vários textos publicados e cerca de trinta anos de presença no cenário intelectual de seu país ${ }^{141}$. A origem, por assim dizer, da concepção de escritura de ambos se situa, entretanto, menos em um marco cronológico e mais em um ambiente cultural, como afirma Piglia em uma das entrevistas publicadas em Crítica y ficción (2001, p. 95):

Empezó a escribir en la década del 60. ¿Significa eso una marca de origen en su literatura?

Espero que sí. Porque creo que los 60, como se los suele llamar, no son una época sino una posición. La circulación de los estilos, el combate, la yuxtaposición, las variantes, cambiar de género y de tonos, manejar colocaciones múltiples. [...] Zafarse de los lugares fijos, mezclar el periodismo y la ficción, el radioteatro y la novela, la historieta con Roberto Arlr, la política con el arte. Frente a la uniformidad liberal de la voz propia, la proliferación y el cambio.

O gesto do combate, da inovação e transformação pela transgressão, será uma maneira de, ao mesmo tempo em que se constrói uma poética pessoal, relacioná-la com o meio social em que está inserida. No entanto, mais importante do que isto, é que esta postura não busca uma ligação direta com a história imediata e, por isso, não a confina ao contexto cultural dos anos sessenta em que surgiram. Saer, em "Literatura y crisis argentina", texto datado de 1982, reflete sobre este tema no contexto específico de seu país (1997a, p. 125):

A primera vista, la pesadilla de nuestra historia reciente parecería justificar el populismo y el miedo al aislamiento respecto de la tradición planetaria, la vanguardia. Sin embargo, esa actitud reaccional esconde, aunque parezca paradójico, un fondo voluntarista y pragmático que se sitúa en las antípodas

\footnotetext{
${ }^{141}$ O primeiro livro, de contos, de Saer se publica em 1960 (En la zona), enquanto o primeiro de Piglia, também uma compilação de narrativas breves, se publica em 1967 (Jaulario).
} 
de la praxis poética. La función de la literatura no es corregir las distorsiones a menudo brutales de la historia inmediata ni producir sistemas compensatorios sino, muy por el contrario, asumir la experiencia del mundo en toda su complejidad, con sus indeterminaciones y sus oscuridades, y tratar de forjar, a partir de esa complejidad, formas que la atestigüien y la representen.

Saer parece coincidir com a visão de Siscar (2010, p. 10) de que a literatura - não importando o contexto em que esteja inserida - não se esgota na dicotomia "vanguarda" versus "populismo", ou "arte autônoma" versus "arte engajada". Ao contrário, ela faz da autonomia estética, da experimentação e da busca por uma expressão singular uma ferramenta que não a aliena da sociedade, mas sim "fornece os recursos para carregar ou suportar os paradoxos de sua inscrição na realidade, atribuindo-lhe a condição de discurso histórico que denuncia, inclusive, as ficções paradisíacas da cultura como identidade entre forma e experiência." (SISCAR, 2010, p. 10, grifos do autor) É deste modo que Saer faz do problema da representação do real uma questão não só estética, mas também política ${ }^{142}$.

Quando Rodolfo Walsh, em uma entrevista dada a Ricardo Piglia em 1970, afirma que "Hoy es imposible en la Argentina hacer literatura desvinculada de la política", a frase não representa, por si, uma postura contrária a de Saer. Ela pode ser interpretada como a representação de um outro ângulo sobre a mesma concepção. Para Diego Alonso (2012, p. 34):

es importante aclarar, como lo hice antes con Walsh, que si bien Piglia sostiene en éste y otros escritos suyos la necesidad de erradicar la ficción cuando se busca "intervenir" en política o efectuar una "representación directa de la realidad", encuentra en la reunión de estos dos elementos el núcleo de una poética posible, en sus palabras, "otra manera de trabajar la política". En este sentido, creo que las lecciones de Walsh - la flexibilidad

\footnotetext{
${ }^{142}$ Como afirmam Carbone e Ojeda, em artigo sobre os escritores atuantes nos anos oitenta e noventa: "Los más extremos - Juan José Saer, por ejemplo - dan un paso más allá para, directamente, plantear una reflexión acerca de la naturaleza humana y su relación con la realidad del mundo [...]. Frente a aquellos escritores preocupados por representar la realidad sin caer en las mentiras del discurso hegemónico, Saer considera que el problema mismo es que la propia sociedad es un espectáculo, una representación. Su apreciación de la dimensión ficcional de cualquier presunta descripción objetiva denuncia en cualquier universalidad una fábula hegemónica." ( 2010, p. 21-2)
} 
de su estilo - dejan una huella en la escritura de Piglia que es interesante pensar. (grifo do autor)

Ou seja, se pensar a literatura - seus problemas de representação, suas concepções estéticas - é também uma reflexão sobre a realidade histórica, pode-se partir, do mesmo modo, da vontade de atuação política e chegar a ela por meio das várias maneiras que assume a ficção - e, não necessariamente pela representação direta da realidade imediata, no fundo só mais um discurso carregado de falsidade que tenta combater uma alienação que ele próprio representa $^{143}$.

Com o fim da ditadura nos anos oitenta na Argentina, cria-se uma certa ilusão ${ }^{144}$, especialmente no âmbito da literatura que ainda se ambiciona "realista", de que certos discursos - na literatura, mas não só nela - estariam livres para "mostrar-se à luz do dia". Entretanto, o que parece ocorrer, na verdade, são dois fatores essenciais: por um lado, a literatura, livre da opressão do autoritarismo político, não se vê automaticamente capaz de expressar a realidade de forma clara e transparente - mesmo sem ditaduras, a literatura não pode "refletir a realidade" -; por outro lado, percebe-se rapidamente que a ditadura política não é a única forma de opressão com a qual a literatura e a sociedade têm que lidar.

O primeiro fator traz à luz o caso das narrativas de e sobre a memória e percebem-se, então, as dificuldades, primeiro, em se formar uma memória depois de um período que tentou, a todo custo, apagá-las e, segundo, em encontrar uma forma para exprimi-la ${ }^{145}$. Os

\footnotetext{
${ }^{143}$ Para Piglia "la literatura trabaja la política como conspiración, como guerra; la política como gran máquina paranoica y ficcional." e "la literatura no refleja nada. Hace otra cosa. La novela mantiene una tensión secreta con las maquinaciones del poder. Las reproduce." (2001, p. 73 e 106)

${ }^{144}$ Aqui talvez fosse melhor, se possível, recorrer ao idioma espanhol, no qual "ilusión" também pode ter o sentido de "esperança".

${ }^{145}$ Mais de vinte anos depois do fim da ditadura, a narrativa ainda busca as formas possíveis (ou impossíveis) para a expressão da memória dos anos de terror da ditadura. Roberto Ferro, em artigo sobre Ciencias morales, de Martín Kohan, texto de 2007, afirma que: "La voz narradora de la novela [...] va diseminando un conjunto de indicios y de marcas que remiten veladamente al contexto histórico-político contemporáneo a los sucesos que va relatando. Su gestualidad parece replicar la circulación de los discursos sociales durante aquellos años, en los que los sobreentendidos desbordaban los silencios impuestos por la dictadura; aunque es preciso señalar que esos sobreentendidos no eran habitualmente una forma de resistencia, sino que, por lo general, eran señales de convalidación del discurso oficial. Asentada en ese registro, la narración se constituye en torno a un conjunto de episodios que exhiben la imposibilidad de producir la supresión irreversible de los acontecimientos en toda su
} 
procedimentos literários extremos, experimentais, singulares, continuam, então a serem requisitados. Além disso, não se pode conceber uma história do "depois", sedimentada na memória, pois, como aponta Avelar, não há propriamente um "depois", não há vitória e superação sucedendo os anos de terror (2003, p. 31):

\begin{abstract}
A irredutibilidade da derrota é para Piglia, Santiago, Eltit, Noll e Mercado [e outros como Saer, agregaria eu], o fundamento da escrita literária. Todos escrevem sob a conjunção de duas determinações fundamentais, o imperativo do luto e a decadência da arte de narrar. O luto e a narração, inclusive ao nível mais óbvio, seriam coextensivos: levar a cabo o trabalho de luto pressupõe, sobretudo, a capacidade de contar uma história sobre o passado. E, de maneira inversa, só ignorando a necessidade do luto, só reprimindo-a num esquecimento neurótico, é que poderíamos contentar-nos com narrar, armar um relato mais, sem confrontar a decadência epocal da arte de narrar, a crise da transmissibilidade da experiência.
\end{abstract}

O segundo fator, o da multiplicidade de faces da opressão pode ser vista no discurso do Estado - ainda que não ditatorial, continua a existir um Estado, que continua a exercer o poder pelo discurso, e vice-versa - e no funcionamento econômico deste submetido ao mercado globalizado dominado pela ideologia liberal. Piglia, por exemplo, aponta como a literatura que se volta para a memória acaba direcionada a um sentimento de culpa da nação como um todo com relação ao terror dos anos de ditadura (2001a, p. 106):

Con la transición de Bignone a Alfonsín. Ahí se cambia de género. Empieza a funcionar la novela psicológica, en el sentido fuerte del término. La sociedad tenía que hacerse un examen de conciencia. Se generaliza la técnica del monólogo interior. Se construye una suerte de autobiografía gótica en la que el centro era la culpa; las tendencias despóticas del hombre argentino; el enano fascista; el autoritarismo subjetivo. La discusión política se internaliza. Cada uno debía elaborar su relato autobiográfico para ver qué relaciones personales mantenía con el Estado autoritario y terrorista. Difícil encontrar una falacia mejor armada: se empezó por democratizar las responsabilidades. Resulta que no eran los sectores que tradicionalmente impulsan los golpes de Estado y sostienen el poder militar los responsables de la situación, sino ¡todo el pueblo argentino!

consistencia histórica, inevitablemente siempre quedan rastros de los que emergen una y otra vez los fantasmas de lo reprimido." (2011, p. 159) 
Rocco Carbone e Ana Ojeda, por sua vez, apontam como desde os anos pós-ditadura na década de oitenta (o governo Alfonsín), e em grande parte como consequência das políticas implementadas pelos governos militares, o Estado vai, cada vez mais se fragilizando e se tornando uma espécie de para-estrutura do poder real ${ }^{146}$, exercido pelas grandes empresas e outras entidades do capitalismo financeiro globalizado. Citando a Alfredo Pucciarelli - cujo livro tem por título uma pergunta que é ao mesmo tempo um excelente resumo da situação: Los años de Alfonsín. ¿El poder de la democracia o la democracia del poder? (2006) -, Carbone e Ojeda resumem assim a situação (2010, p. 17):

El Estado democrático perdió "autonomía y soberanía a manos del sector privado y sus instituciones, funcionarios y política se hallan cada vez más subordinadas a las estrategias de acumulación puestas en marcha por las grandes empresas líderes del nuevo modelo de acumulación "liberal corporativo' diseñado durante ese período".

Este projeto liberal-conservador, gestado desde o início dos regimes autoritários no país ainda nos anos sessenta e ao qual o governo de Raúl Alfonsín, a bem da verdade, não opõe - ou não consegue opor - muita resistência, encontrará um Estado que lhe será totalmente favorável e receptivo no governo de Carlos Memem (1989-1999) ${ }^{147}$ (CARBONE \& OJEDA, 2010, p. 37):

El gobierno menemista propuso un salto violento, audaz - pero sobre todo definitivo (por el tiempo que duró) - hacia el pensamiento único y fundamentalista del neoliberalismo. Articuló las ideas económicas del liberalismo con un proyecto político neoconservador, dotando a un proyecto liberal con una base de masas.

\footnotetext{
146 “También se advirtió en el ámbito de la economía, en el que el nuevo poder económico fortalecido durante la dictadura militar despojó al Estado democrático de su rol protagónico, de forma que éste ya no tuvo capacidad para dirigir, orientar ni poder en marcha sus tres grandes objetivos iniciales: la reindustrialización, el desarrollo y la modificación del esquema de distribución del ingreso." (CARBONE \& OJEDA, 2010, p. 17)

${ }^{147}$ Para mais detalhes sobre o período, ver o volume compilado por Carbone e Ojeda na coleção dirigida por David Viñas: De Alfonsín al menemato 1983-2001: literatura argentina siglo XX. Buenos Aires: Paradiso; Fundación Crónica General, 2010.
} 
Os reflexos do projeto liberal que se superpõe e depois sucede o período dos governos ditatoriais se espalham por toda a vida social, e não só na Argentina. Também no resto da América Latina e em grande parte do mundo vão se consolidando visões sobre a sociedade, a política, a cultura, a arte, que reproduzem, de uma ou outra maneira os ideais do liberalismo econômico. Assim, o gesto transgressor - vanguardista, se se queira - na literatura e na arte em geral é solapado por uma tentativa de pensamento unívoco que prega a facilidade e a repetição acomodadas ao consumo e a superação dos conflitos históricos e políticos - o contrário da "irredutibilidade da derrota" de que fala Idelber Avelar. É este nivelamento, que busca converter o objeto artístico em uma mercadoria mais e o fazer do artista em mais um trabalho alienado a serviço do capital, que nota e combate o mesmo Avelar, ao mesmo tempo em que percebe uma vinculação desta nova situação cultural com o conceito - ou, ao menos com uma "etiqueta" - de pós-modernismo (2003, p. 127):

Na pós-ditadura se observa o retorno generalizado ao "senso comum" e ao
"realismo" da acomodação aos limites do possível. Os progressistas
devemos ter "aprendido uma lição" sobre o "respeito à democracia e à vida".
A necessidade de autocrítica por parte da esquerda se confunde, demasiado
facilmente, com uma submissão tranquila à autoritária e limitada democracia
liberal das pós-ditaduras latino-americanas. Na esfera literária, este giro
antiutópico encontra sua expressão numa versão conservadora do pós-
modernismo, que responde à exaustão da assinatura modernista resignando-
se a um modelo de relato casual, "puramente literário", livre de
experimentação, conservador estética e politicamente.

Os movimentos transgressores que se podem atribuir à escritura de La pesquisa e Plata quemada podem ser lidos, então, também como uma forma de atuar criticamente dentro desta lógica liberal imposta à sociedade, que também percebem e combatem, já desde os anos oitenta, Saer - em "Literatura y crisis argentina", de 1982 - e Piglia - em resposta dada em uma entrevista realizada por Raquel Ángel, em 1987: 
[P]odemos hablar de una determinación externa, de orden planetario, cuya ausencia misma en el interior de una literatura concreta puede ser considerada como un síntoma y que presenta, también, dos aspectos: [...] [uno de ellos es] el de la implantación multinacional de la industria cultural que substituye la creación artística por una mercancía indiferenciada y opone al impulso antropológico del arte las leyes económicas de la oferta y la demanda." (SAER, 1997a, p. 99-100)

Según David Viñas, la propuesta de muchos intelectuales en este momento es: "Hay que aceitarlo todo, hay que tranquilizar conciencias" ¿Coincide usted?

A menudo lo fundamental reside en aceitar la propia conciencia. Pasar de la tradición de los vencidos a la tradición de los vencedores. Adaptarse al retro neoconservador, a la elegancia cínica, a la defensa del orden, a la muerte de las vanguardias. (PIGLIA, 2001a, p. 102)

Por fim, do mesmo modo que Avelar, também Saer e Piglia identificam no conceito de pós-modernismo uma reação aos movimentos de transgressão próprios da atitude modernista no século XX, que, no fim das contas, permitem a emergência de uma literatura ao mesmo tempo problematizada, singular e nova:

A pesar de su reivindicación de la libertad en arte, el posmodernismo está estrechamente ligado a la ideología oficial de los ultraliberales. Su democratismo - que no tiene nada que ver con la verdadera democracia, cuyas exigencias y responsabilidades éticas y sociales son irreconciliables con el liberalismo salvaje - se contenta con reivindicar las más blandas y vagas categorías del consenso, para el cual toda tentación de ruptura es inmediatamente excluida del debate. (SAER, 2006a, p. 11)

¿EI llamado posmodernismo sería el contexto actual de esta situación?

Bueno, por supuesto que es una etiqueta, o se ha convertido en una etiqueta que no quiere decir nada. Pero creo que hay un punto central, la máquina del posmodernismo viene a decir que la cultura moderna ha terminado por imponer y legitimar a los transgresores y a los revolucionarios [...] Por lo tanto, se vendría a decir, hay que construir una cultura nueva posmoderna, posterior a la cultura moderna, que esté de acuerdo con las necesidades de la sociedad. Una cultura que valore en todos los planos (en la literatura, en la vida cotidiana, en la política) lo que había sido negado por la vanguardia, por la transgresión, por la revolución. (PIGLIA, 2001a, p. 103-4) 


\section{A narrativa policial em uma tradição argentina}

Ao tratar das apropriações de um gênero no contexto de uma literatura nacional, voltamos à questão das concepções que se pode ter de gênero, mas também de "literatura nacional". ${ }^{148}$ Quanto ao primeiro conceito, voltamos às três propostas já apresentadas: o gênero como categoria da indústria cultural, como uma categoria de leitura e como uma forma de manifestação histórica do discurso. As relações do policial com a literatura argentina, com as poéticas narrativas de Juan José Saer e Ricardo Piglia e com La pesquisa e Plata quemada podem ser pensadas a partir de qualquer uma dessas abordagens. O que proponho aqui é, por um lado, entrelaçá-las, partindo do princípio que os diferentes conceitos de gênero, na verdade, se inter-relacionam, e, por outro, pensá-las tendo como objeto final da análise a realização concreta dos dois romances.

Pensar o gênero a partir de uma tradição literária, para começar, supõe pensá-lo enquanto manifestação histórica não só de um tempo específico, mas também de um contexto social que envolve a cultura, a política, a economia, a língua, etc. Neste sentido, segundo Bakhtin, em “Tipologia histórica do romance” (2010, p. 205):

Nenhuma modalidade histórica concreta mantém o princípio em forma pura mas se descaracteriza pela prevalência desse ou daquele princípio de enformação da personagem. Uma vez que todos os elementos se determinam mutuamente, um determinado princípio de enformação da personagem está vinculado a um determinado tipo de enredo, a uma concepção de mundo, a uma determinada composição do romance.

\footnotetext{
148 "Recortar un objeto, aislarlo para definirlo y finalmente imponerle un aparato teórico y crítico, parecen ser las instancias básicas de cualquier análisis académico que se jacte de un mínimo rigor metodológico. [...]¿Cómo se define(n) el (los) género(s)?¿Cómo especificar y relevar los modos de participación o pertenencia de un texto a su instancia genérica? ¿Cuáles son las variantes de esta categoría?” (RUD, 2001)
} 
Mesmo Saer, que, por diversos motivos, mantém consideráveis reservas com relação ao conceito de "literatura nacional" 149 , reconhece, por outro lado, o caráter do nacional como ponto de partida, especialmente através da leitura, para a formação de uma visão de mundo de um escritor, inclusive ele mesmo ${ }^{150}$. Assim, chegamos à percepção de que dificilmente o gênero policial será uma categoria contornável na formação de um escritor argentino, e que este estará ligado a uma tradição particular do gênero pela forma como este se desenvolveu no país.

Em trabalhos de maior ou menor extensão, maior ou menor profundidade ${ }^{151}$, muitos são os textos que fazem um recorrido da história do gênero na Argentina. Ainda que variando em suas descobertas ou valorizações de determinados escritores, todos coincidem em alguns pontos, a começar por um certo pioneirismo na utilização do gênero nas letras latinoamericanas, com escritores como Eduardo L. Holmberg, Luis V. Varela e Paul Groussac,, ainda em fins do século XIX e começo do XX. Os primeiros passos do policial no país começam com traduções de obras estrangeiras - inglesas e francesas, essencialmente - e se seguem com o uso do modelo europeu do gênero em "cópias" (com curiosas cores locais) feitas por escritores nacionais. Essas duas operações - a tradução e a cópia, ou o plágio - não só seguirão vigentes até a década de 1930, pelo menos, como vão configurar dois modos de apropriação que podem ser aplicados à formação da literatura argentina - a literatura de um país cultural e economicamente periférico - de uma maneira mais ampla, como veremos adiante. Por hora, é interessante notar a grande quantidade de escritores, de reconhecida qualidade estética e com poéticas inovadoras, que traduziram, até os dias de hoje, narrativas

\footnotetext{
${ }^{149}$ Ver a este respeito, por exemplo, os artigos "La selva espesa de lo real" ou "Una literatura sin atributos", publicados em El concepto de ficción (1997a, p. 267-71 e 272-6)

${ }_{150}$ Ver, por exemplo, "Libros argentinos", em Trabajos, texto no qual Saer fala de suas leituras da literatura argentina (e suas reações a elas) desde a infância, citando o Martín Fierro de José Hernández, Roberto Arlt, Jorge Luis Borges, Oliverio Girondo, Juan L. Ortiz, Antonio di Benedetto, Macedonio Fernández, entre vários outros escritores. (2006a, p. 189-96)

${ }^{151}$ Ver, por exemplo, LAFFORGUE \& RIVERA (1996); BARBOZA (2008); BERG (2008b); DELANEY (2006); e PICABEA (2012).
} 
policiais dos mais variados tipos, tanto na Argentina - Jorge Luis Borges ${ }^{152}$, Julio Cortázar ${ }^{153}$, César Aira ${ }^{154}$-, como, diga-se, também no vizinho Brasil - Monteiro Lobato ${ }^{155}$, Érico Veríssimo $^{156}$, Clarice Lispector ${ }^{157}$, Flávio Moreira da Costa ${ }^{158}$.

O movimento de tradução e cópia - que por outro lado é, eminentemente, um movimento de leitura - do gênero só se rompe a partir da década de 1930, primeiramente com Jorge Luis Borges. A partir de então, outros escritores, como Rodolfo Walsh, passam da apropriação do gênero simplesmente à produção de uma estética nova e própria a partir dele. O mesmo vai acontecer da década de sessenta em diante, com a repercussão na Argentina do policial negro - até então pouco divulgado no país. Muito devido à relação que esta vertente do policial faz entre a escrita, o crime e a sociedade, novas tentativas de produção de uma literatura policial nascida de um contexto específico argentino surgem em figuras como Juan Carlos Martini e Juan Sasturain (segundo BERG, 2008b, entre outros).

O modo com que essa literatura policial argentina com características próprias vai surgindo, entretanto, está intimamente relacionada com os modos como ocorreu a apropriação da literatura policial estrangeira no país, que, por outro lado, é a forma com que a literatura argentina em sentido mais amplo se formou por esses mecanismos de apropriação. Para Ana María Amar Sánchez (2000, p. 46):

la historia del género en América Latina es un ejemplo de su flexibilidad y de sus posibilidades más allá de la fórmula. [...] los policiales latinoamericanos, en especial desde Borges, han usado las formas canónicas libremente, parodiándolas e integrándolas con otras. La historia del género en la Argentina es ejemplar de este proceso: Borges parodia pero también

\footnotetext{
${ }^{152}$ Edgar Allan Poe (La carta robada, Madrid: Ed. Siruela, 1987); G. K. Chesterton.

${ }^{153}$ Chesterton (El hombre que sabía demasiado, Buenos Aires: Nova, 1946); Poe ( Obras en prosa, trad., intr. y notas de J. Cortázar; Río Piedras: Ediciones de la Universidad de Puerto Rico, en colaboración con Revista de Occidente, 1956, 2 vols.; Cuentos, La Habana: Editorial Nacional de Cuba, 1963)

${ }^{154}$ Raymond Chandler (Adiós, muñeca, Buenos Aires : Emecé Editor, 1988; La hermana menor, Buenos Aires : Emecé Editor, 1989)

${ }^{155}$ W.R. Burnett (O pequeno César. Rio de Janeiro: Civilização Brasileira, 1961).

${ }^{156}$ Horace McCoy (Mas não se mata cavalo? São Paulo: Abril Cultural, 1982).

${ }^{157}$ Agatha Christie (Cai o pano. Rio de Janeiro: Nova Fronteira, 2009).

${ }^{158}$ Raymond Chandler (O longo adeus. Porto Alegre: L\&PM, 2009).
} 
transforma el relato de enigma. Usa y cuestiona los elementos que lo constituyen. Desde entonces y hasta este fin de siglo, el policial en América Latina se define por su trabajo de "deformación" y explotación de las variables implícitas en las fórmulas.

A filosofia por trás do uso e do questionamento dos elementos do gênero que faz Borges, no entanto, não é a única que norteia a apropriação do modelo estrangeiro na Argentina e nem é a única que vai pautar a produção de todos os escritores que transitam pelo policial daí em diante. Como aponta Manuel Rud (2001), há ao menos dois modos de se ver a apropriação da cultura estrangeira, simbolicamente ligados a Borges e a Roberto Arlt. Borges (Rud baseia-se aqui modelarmente no artigo "El escritor argentino y la tradición" (1977)) propõe a literatura argentina como parte da tradição literária ocidental e a apropriação do policial, ainda que transgredido, como forma de renová-lo e torná-lo um instrumento de manutenção de uma ordem necessária no seio dessa tradição ${ }^{159}$. Já Arlt (representado simbolicamente pela cena de El juguete rabioso (2008) em que se roubam livros de uma biblioteca) conforma uma posição diferente: é a partir do roubo - do crime e da desordem, portanto - que se configura um espaço de apropriação da leitura ${ }^{160}$. Como os modos de apropriação e de leitura são os que configuram os modos de escritura que lhe seguem, a mera existência de concepções diferentes para esta apropriação gera, por consequência, diferentes concepções da escrita. Tratando especificamente do gênero policial e da Argentina, Rud (2001) conclui, então, que:

En la hipótesis de Piglia, el robo no es sólo posible sino necesario. Evidentemente, el propio Borges acordaría con esta afirmación ("El escritor

\footnotetext{
${ }^{159}$ Rud (2001) cita o artigo "O conto policial”, de Borges, em que este afirma: "Que poderíamos dizer como apologia ao gênero policial? Há algo por demais evidente e correto: nossa literatura tende ao caótico. Tende-se ao verso livre, por ser mais fácil que o verso regular; na verdade, é muito difícil. Tende-se a suprimir personagens, argumentos, tudo é muito vago. Nesta nossa época, tão caótica, há algo que, humildemente, tem mantido as virtudes clássicas: o conto policial. [...] Eu diria, em defesa do romance policial, que ele não precisa de defesa; lido, agora, com certo desdém, está, contudo, salvando a ordem em uma época de desordem. Esta é uma prova de que devemos ser-lhe gratos e de que tem méritos.” (BORGES, 1999a, p. 230)

${ }^{160}$ A mesma imagem, relacionada ao mesmo raciocínio que desenvolve Rud, é mencionada também por Roberto Ferro (2009, p. 246), que, de igual modo, trata da narrativa policial latino-americana.
} 
argentino y la tradición" es, como vimos, una vindicación de este concepto). Sin embargo, la apuesta por el asedio a las diferentes posibilidades genéricas implica aquí un componente de interpretación histórica además de una serie de pautas formales: leer en el crimen la ficción y la ficción en el crimen, leer en los géneros las formas de circulación de otras series, universos que intiman y se descomponen en su propio proceso.

Entre as diferentes possibilidades genéricas abordadas, entretanto, nem todas produzirão um literatura original, como aponta Elvio Gandolfo em "Perdónalos, Marlowe, porque no saben lo que hacen" (2007, p. 159-63). Isto se deve a dois fatores essenciais: a incapacidade - ligada ao talento de cada escritor em particular - de se passar da apropriação à escrita que não seja mera tradução, cópia ou adaptação, ou a falta de interesse em fazê-lo. Este último fator, por sua vez, pode se dever ao menosprezo ao gênero policial, que, como gênero “menor", não mereceria ou não ofereceria possibilidades de transformação. Por outro, lado, partindo-se da mesma concepção, há os que se contentam com a reprodução de fórmulas, com vistas a uma melhor aceitação do mercado literário. Por isto, me parece que Amar Sánchez comete duas imprecisões em seu artigo "El crimen a veces paga. Policial latinoamericano en el fin de siglo." (2000). A primeira está no ponto de chegada, ao generalizar o caráter transgressor das produções do gênero policial na América Latina - há, sim, repetição de fórmulas, mesmo consciente, no subcontinente, como o apontam, por exemplo, Martha Barboza $^{161}$ e Jorge Laforge (em entrevista a María Luján Picabea ${ }^{162}$ ). A segunda, no ponto de partida, ao, lembrando Umberto Eco, falar da "severidad de las estéticas modernas con los productos de la cultura de masas, precisamente por su condición serial y repetitiva." Mesmo ressaltando o caráter original e transgressor da produção latino-americana, Amar Sánchez

\footnotetext{
161 "En definitiva, puede decirse que la formación de una 'serie negra argentina' sigue, por una parte, el formato convencional y reproductivo de las pautas constructivas norteamericanas que responden a los requerimientos editoriales de mercado, ya que en estas producciones resulta difícil detectar una búsqueda de diferenciación con el modelo canónico. Por otra parte, se puede observar, casi simultáneamente, una apropiación del género efectuada por escritores que habitualmente se concentran en otras formas narrativas. Es precisamente en estas últimas producciones donde la nueva literatura policial argentina experimenta todo un proceso de desautomatización y transformación, producto de las condiciones sociales que la determinan." (2008)

162 "Yo distinguiría un par de cuestiones -explica Lafforgue- por un lado hay un grupo de narradores que se asumen como escritores de policiales, y en cuyas obras los signos del policial son claros, y otro sector de escritores que me interesan porque marcan un camino tal vez distinto." (PICABEA, 2012)
} 
parece partir da ideia de que esta se faz apropriando-se do gênero exclusivamente concebido como manifestação da cultura de massas.

A concepção do policial dentro do contexto da cultura de massas, da indústria cultural e da literatura popular e "menor" é compartilhada por muitos autores que, como Todorov (2003a), só vêem o gênero desta maneira, ou que o vêem, em algum momento, prioritariamente desta maneira (Barboza ${ }^{163} ; \operatorname{Berg}^{164}$, Rud ${ }^{165}$, Ferro ${ }^{166}$ ). Ainda que estes apontem, em seguida, como diversas estratégias de transgressão resultam em uma escrita pessoal e original, fica a impressão que esta é entendida, na verdade, sempre como uma forma de "pós-policial”, uma escrita que já não participa do gênero na tentativa de suplantá-lo. Se o policial é visto, antes de tudo, só como um produto da cultura de massas feito de fórmulas repetidas à exaustão, não haveria possibilidade de se fazer uma literatura singular, experimental e ousada a partir dele. O gesto de transgressão, aqui, não poderia reconfigura o limite, pois não há uma dinâmica possível. Como o próprio Juan José Saer afirma no ensaio "El largo adiós", sobre Raymond Chandler: "Es necesario considerar la literatura policial desde dentro, no desde afuera, si se quiere entender la singularidad artística de algunos de sus autores y ver con claridad las modificaciones creadoras que introducen en el género." (1997a, p. 252-3) Curiosamente, o próprio Chandler, em “A simples arte de matar”, já defendia esta

\footnotetext{
163 "En este trayecto histórico del género, la cultura de masas se constituye en el ámbito más apropiado para su difusión y circulación, y dentro de ella lo policial y sus diferentes manifestaciones discursivas se instalan en el espacio de la llamada "literatura menor", pensada sólo para ser consumida por las clases populares." (BARBOZA, 2008)

164 "La novela y el relato policial son unas de las manifestaciones típicas de los productos literarios de la cultura de masas y podríamos decir que, hasta no hace mucho tiempo, eran consideradas como productos culturales de poca monta" (BERG, 2008b)

165 "El problema se torna más complejo cuando se trata de indagar en textos que participan de géneros que tienden a constituirse con la 'firmeza de la repetición', es decir, producciones cuya estructura remite a una serie anterior y la reenvía, en sus modos de acoplamiento y constitución, a ciertos modelos o moldes de percepción definidos social e históricamente: estos géneros a los que nos referimos, nacidos a la luz de la cultura de masas y la producción industrial, parecen indefectiblemente ligados a su origen, y, por esto, ponen en escena más que ningún otro, la relación tensionada entre arte y consumo en la modernidad." (RUD, 2001)

166 "Los componentes distintivos del género están marcados por un alto grado de permanencia y estabilidad, que asegura el reconocimiento de los lectores, centrando la variación en el talento del escritor para producir una combinación sorprendente. De ello se desprende que el género policial pueda ser concebido en términos de modelo productivo." (FERRO, 2009, p. 231-2)
} 
mesma postura de Saer contra a apresentada anteriormente, que ele nota em Doroty Sayers, também, ironicamente, uma escritora de policiais (2001, p. 175-6):

\begin{abstract}
Em sua introdução ao primeiro Omnibus of Crime, Dorothy Sayers escreveu: "Ela [a história de detetive] não tem como, e por hipótese jamais terá como, alcançar o nível mais elevado de realização literária". Esta mesma autora também sugeriu, em outro texto seu, que isto se deve ao fato de ser a história de detetive uma "literatura de fuga da realidade" ("literature of escape") e não "uma literatura de caráter artístico" ("literature of expression"). Eu não sei o que seja o nível mais elevado de realização literária. Tampouco Esquilo ou Shakespeare o sabiam. E muito menos o sabe a Srta. Sayers. Todo o resto permanecendo igual, o que, por sinal, jamais aconteceu, um tema mais forte provocaria uma performance mais forte. Entretanto, alguns livros extremamente desinteressantes foram escritos sobre Deus, e outros, muito bons, sobre como ganhar a vida e continuar sendo um sujeito honesto dentro do possível. Sempre é uma questão de quem escreve o material e o que este autor tem dentro de si que o leva a escrever.
\end{abstract}

Partir da concepção do gênero policial entendido somente como produto da cultura de massas é, evidentemente, possível. Entretanto, limitar a análise dos efeitos da literatura de gênero - entendida deste prisma - no campo do mercado e da produção literária, por exemplo, me parece mais adequado a estudos de tipo sociológico. Além disto, seguir esta linha poderia desviar a pesquisa da leitura mais profunda dos textos em relação com a poética de seus autores e a literatura em geral, que é o que se busca aqui em última instância. Entre as maneiras de se considerar o policial a partir de uma de suas lógicas internas, há até a possibilidade de se utilizar, na escrita literária, "aquilo que dramatiza o conflito entre sua especificidade e seu sentido geral, entre seu 'lugar no mercado' e a dissimetria das trocas, entre a moral da equivalência geral entre os indivíduos e a possibilidade de dizer tudo (de dizer o impossível, de admitir o inadmissível)", como diz Marcos Siscar (2010, p. 39), mas este não é o único caminho. Quando Rodolfo Walsh, um dos formadores e participantes da tradição literária - e também do gênero policial - na Argentina publica o artigo "Dois mil e quinhentos anos de literatura policial" (2011, p. 221-5), fica claro que para ele, por exemplo, a 
concepção do gênero vai além das questões da modernidade e guarda uma lógica interna que, ao menos em alguns aspectos é perene.

Partindo da leitura para a definição do policial - como o faz o próprio Jorge Luis Borges, em "O conto policial” (1999a) - é possível, entre tantas alternativas, chegar à escritura de um novo exemplar do gênero pela paródia, por exemplo. Esta, no entanto, não pressupõe automaticamente o surgimento de uma poética nova ou original, e muitas das paródias feitas ao gênero se esgotam em si mesmas - remetendo ao "diferente" que, reconhecido pela associação com o anterior, não pode ser novo, de acordo com Groys (2013). Por isso Manuel Rud (2001) adverte que:

Ya desde lo paródico o el registro satírico, [...] Borges produce una relectura de la historia del género y una práctica que se apropia de esa relectura y que surge como novedosa y iniciática, superadora de las producciones más o menos ortodoxas del relato-problema que circulaban en la época (Peyrou, Castellani, e incluso de aquellas con una búsqueda "estilística" más consistente, como Pérez Zelaschi o el propio Walsh) rescatando los recursos para la consolidación, desde la plenitud de lo artificial, de un orden que supone perdido.

Por isto também, a respeito de La pesquisa, Saer afirma que "Me pareció que volver a los orígenes del género podía ser una solución interesante no para parodiarlos, sino para tomarlos otra vez como punto de partida y avanzar a partir de ellos en mi propia dirección" (apud TORRE, 2012). Assim, ler o policial como narrativa sobre uma narrativa e como narrativa que articula socialmente na ficção os conceitos de crime, lei e verdade, ainda que resulte em um conceito bastante aberto para a abordagem do gênero, parece ser um ponto de partida mais equilibrado, que não o toma como uma estrutura pétrea, só abordável por movimentos de apropriação que repliquem suas convenções ou a satirizem, geralmente com resultados pouco transgressores ${ }^{167}$.

\footnotetext{
${ }^{167}$ Insistir no conceito de "paródia" do policial na literatura argentina, como o fazem, por exemplo, Barboza (2008) e Pellicer (2007) parece um tanto superficial e arriscado. O conceito - cuja definição pode variar
} 
A maleabilidade que tal definição, ampla e aberta, cria para o gênero policial, pode gerar, entretanto, um paradoxo: o de que justamente pensar um ponto de partida flexível no gênero policial que abra caminho à experimentação e à originalidade, abre caminho também para a consolidação das fórmulas e suas adaptações a novos contextos - geográficos e temporais, como o nota Barboza ${ }^{168}$. No que tange ao original e experimental, no entanto, é possível pensar uma situação em que o policial "supera ampliamente el marco convencional del género y abre un espacio desde donde efectuar planteamientos e indagaciones más complejas sobre el problema de la ficción, la identidad del escritor y los códigos lingüísticos que participan de una escritura que quiere ser diferente" (BARBOZA, 2008). É o que propõe Chandler em relação a Dashiell Hammett, que, segundo ele, provocou um "desmascaramento verdadeiramente revolucionário tanto da linguagem quanto do material ficcional" e, ainda assim, "não aniquilou com a história formal de detetive", demonstrando "que a história de detetive pode resultar num texto importante.” (2001, p. 179-82) Assim, Hammett e o próprio Chandler passam a uma categoria de literatura mais ampla - e mais elevada - dentro do contexto norte-americano, que conta com figuras como Hemingway ou Faulkner - que, por sua vez, experimentaram também com o gênero policial. É desta perspectiva mais aberta que todos esses autores são lidos por muitos escritores latino-americanos - como aponta Mempo

radicalmente da concepção de Tynianov, em "Da evolução literária" (1971), à de Linda Hutcheon, em Poética do pós-modernismo (1991) - corre o risco de se transformar em um aparato vazio para tratar de qualquer trabalho feito com o gênero, trabalho do qual, às vezes, nem os escritores nem os críticos parecem ter consciência do significado e das consequências estéticas.

168 "Este modelo formal ideado por Poe se constituye, además, a partir de una mirada particular de la realidad y de un contexto social que responden al paradigma de la modernidad. [...] Es importante destacar también que la iniciativa de Poe, a fuerza de repeticiones y renovaciones, supera las fronteras del cuento, espacio narrativo para el cual había sido pensado, y abre un campo discursivo en el que confluyen múltiples y diversos discursos que, en cierto modo, se construyen sobre la base ideada por Poe. La diferencia no está dada por los elementos y rasgos tipificadores del género, sino por el modo de disponerlos, por el medio utilizado para conformarlos y por los matices añadidos para salvar la repetición. [...] El género policial (tanto el clásico como el negro) se configura, entonces, a partir de una cooperación textual que presenta su discurso como un artificio sintácticosemántico-pragmático, cuya interpretación, de algún modo, está prevista en su propia gestación.” (2008) 
Giardinelli (1991) - e é a partir dela que vários deles, como Manuel Puig, Juan José Saer e Ricardo Piglia, incorporam o gênero a suas poéticas ${ }^{169}$.

\section{O policial em poéticas singulares: La pesquisa e Plata quemada}

Pensar a relação entre o gênero e realizações particulares dentro de poéticas narrativas complexas e singulares pode ser uma tarefa complicada. Por um lado, é possível cair ainda em definições estanques do gênero que não lhe são próprias intrinsicamente, mas convenções dentro da série histórica. Por outro, há o risco de se superdimensionar o desvio dentro da poética de um determinado autor. María Helena Torre, por exemplo, em um artigo de fato pertinente e com várias colocações interessantes, peca, em meu entender, em duas colocações. Na primeira, quando sustenta que a inscrição no gênero de La pesquisa, de Saer, só é possível "por la presencia del detective Morvan, y la narración de una investigación, porque la ambigüedad de la resolución final (las dos versiones), representa la (irre)solución de un enigma que abre una nueva lectura de la novela y del género.” (2003) Na verdade, um dos contos fundadores do gênero - "O assassinato de Marie Roget”, de Poe - não apresenta uma solução fechada para o caso e mesmo uma história de Sherlock Holmes, como "O problema final", faz o mesmo. Ou seja, me parece que a definição do policial pela investigação é procedente, mas a falta de uma conclusão inequívoca para tal investigação não invalida a pertinência ou representa um desvio inédito nas práticas narrativas do gênero. Em uma segunda colocação sobre o romance, Torre afirma que, como na narrativa clássica de enigma, ele se constrói sobre duas histórias, mas que:

\footnotetext{
${ }^{169}$ Este procedimento é notado por Manuel Rud, Edgardo Berg e Clemens A. Franken, entre outros. María Elena Torre, falando de Respiración artificial e La pesquisa, por exemplo, afirma que "La lógica del policial se ha alterado, las convenciones del género han servido no para ajustarse a ellas sino más bien para experimentar con la forma narrativa de la novela, adaptando el género al sistema narrativo personal. Por otro lado, el manejo del enigma, categoría fundamental del relato policial, ha permitido en ambos relatos la exasperación de la forma." (2003)
} 
contradiciendo las reglas del género no se trata de la historia del crimen y la historia de la investigación, sino de dos historias que parecieran no tener puntos en común, ambas con sus enigmas, sólo vinculadas por la figura de un narrador, Pichón Garay, que aparece en la segunda parte del relato dándole presencia a una voz que venimos escuchando desde el comienzo. (2003, grifo da autora)

Entretanto, a concepção do policial como narrativa sobre uma narrativa não é contradita, mas aprofundada. Pichón conta duas histórias - a do crime e a da investigação como no modelo tradicional, mas é contado por uma primeira instância na narrativa do romance do qual ele é personagem. E há, além disto, as outras "narrativas que são narradas por narrativas": o texto de "En las tiendas griegas", os livros de mitologia de Morvan, os relatórios psiquiátricos, etc.

Outro caso que parece mais problemático é o do artigo "El cadáver vuelve a la biblioteca: El género policíaco en la Argentina a partir de 1990”, de Rosa Pellicer (2007). Tratando de vários escritores argentinos da década de noventa, o texto já parte, no caso da análise de La pesquisa, de um lapso, ao atribuir a narrativa policial a Tomatis e não a Pichón. Outros elementos, no entanto, são mais questionáveis, como ver a "estructura clásica" do policial alterada pelo fato do detetive ser o assassino. Ainda que não se saiba pelo texto exatamente o que se considera a estrutura clássica, um exemplo, ao menos, bastante canônico - e bastante antigo - no policial de enigma já apresenta um detetive assassino: $O$ mistério do quarto amarelo, de Gaston Leroux, publicado pela primeira vez em 1907. Volta-se a tomar uma característica contingencial da narrativa - uma que, em ao menos um dos "decálogos de regras" do gênero, estaria proibida - como característica essencial do policial sendo transgredida. Provavelmente, é a partir de outros raciocínios análogos que Pellicer chega a caracterizar La pesquisa como "novela policíaca metafísica”, termo que o próprio Saer rejeita 
ao tentar explicar seu desafio ao escrever o romance ${ }^{170}$. Talvez pela ânsia de abarcar toda uma década de produção de autores dentro de um gênero, algumas considerações parecem precipitadas e várias generalizações, apressadas, como a conclusão de que procedimentos metaliterários - que de fato existentes em muitas narrativas do período - indicam um possível filiação à "narrativa pós-moderna" - vista com tantas reservas tanto por Piglia como por Saer, por exemplo. Também a relação entre a ficção e a realidade analisada em Plata quemada - e outras obras - parece insistir demasiado no conceito de paródia do modelo norte-americano de policial transgredido quase unicamente pela "adaptação" deste à situação sociopolítica argentina. Daí a interpretação com uma ênfase desmedida nos "fatos reais" em que se basearia o romance de Piglia. Para Pellicer (2007):

A diferencia de las investigaciones anteriores ahora Piglia lleva a la ficción un hecho real y el narrador, como explica en el epílogo, se convirtió en detective. De algún modo esta novela se relacionaría con el modo de escritura de Walsh: un historiador del presente que en nombre de la verdad denuncia los hechos, pero que es capaz de unir la oposición entre ficción y poética por medio de la investigación.

Mas o que diferenciaria a narração de "fatos reais" de Plata quemada do que a própria autora chama de "la supuesta narración de hechos reales" presente em La pesquisa na narrativa de Pichón, ou mesmo do que é narrado em outros romances e contos de Piglia? E até que ponto os narradores de Plata quemada e de Operación masacre, por exemplo, falam de uma mesma posição narrativa?

Mais feliz em uma definição da poética de Piglia - que, no meu entender, também perpassa todas as suas narrativas, não excluindo, por exemplo, Plata quemada, como uma exceção - é Edgardo Berg, ao afirmar, em “Asesinos por naturaleza: sobre Plata quemada de Ricardo Piglia (segunda reflexión)" (2001, p. 96-7):

\footnotetext{
${ }^{170}$ Afirma Saer no artigo "La pesquisa", publicado no jornal Clarín, de Buenos Aires, à época do lançamento do romance: "El 'policial metafísico' que nos anuncian tantas previsibles contratapas es un género tan trasnochado como el soneto modernista." (1999, p. 159)
} 
Son textos, los de Piglia, que, en muchos casos, se desarrollan en las fronteras de la narración literaria y, muchas veces, incorporan problemáticas y ejecutan formas del relato que exceden el estrecho marco de los géneros. En ellos hay vibración de límites, ya que toda referencia es cambiante en la medida en que los términos no pueden considerarse fijos o estables. Este fenómeno puede ser visto ya sea desde la práctica de fusión o las señales de mixtura entre discursos heterogéneos -ficción e historia, crítica y relato o ficción y teoría como formas narrativas intercambiables y paralelas -, por los fenómenos de frontera - los desplazamientos o deslizamientos de un registro a otro, de un género a otro-; $y$, por último, en la discontinuidad o yuxtaposición de fragmentos narrativos que eliminan o socavan el estatuto tradicional de novela, provocando como efecto de lectura la deformación de la sintaxis narrativa tradicional.

Assim, na ficção de Piglia, são as formas de discurso que se mesclam e os gêneros que se superpõem. Além disto, nela a relação da literatura com a realidade é mais problemática ao lidar com questões de representação literária e com o discurso do Estado - grande gerador também de ficções.

Também acertada parecem ser as considerações de Myrna Solotorevsky, sobre La pesquisa de Saer, ao afirmar que (1998, p. 437-8):

este texto literario exhibe un principio teórico inherente a la literatura: el lector ha de dar crédito irrestringido a lo configurado por el texto [...]. De este modo, el final de la metadiégesis [la narrativa policial de Pichón] resulta ambiguo; la no resolución del enigma corresponde a la imposibilidad de captar lo "real" o "verdadero", imposibilidad que el texto preconiza y que es rasgo relevante en el código de Saer.

Roberto Ferro, generalizando suas considerações ainda mais do que Berg e Solotorevsky e estendendo-as a todo o âmbito latino-americano, consegue, ainda assim, uma boa observação da literatura policial que de fato transgride o gênero na elaboração de uma poética original e singular (2009, p. 232):

Por una parte, es un corpus privilegiado para investigar los desplazamientos del referente hacia la referencia, marca relevante de la literatura contemporánea. Desde una mirada genealógica la narrativa policial exhibe 
desplazamientos notables que implican cambios de percepción crítica y un incremento progresivo en el interés de una gran cantidad de escritores que forman parte del espacio literario por tramar sus textos en relación con los dispositivos del género. Esa variación de la percepción crítica está íntimamente ligada a las características específicas del policial, acaso uno de los géneros que más mortifica la verosimilitud realista del referente. La productividad del texto, la escritura como relectura, la disolución de los personajes y la identidad del narrador, el entramado indecidible entre el metatexto y la intriga ficcional, la exhibición desaforada de la ficción como procedimiento, el doble juego entre el discurso objeto y el metadiscurso, aparecen de un modo más nítido en las variaciones operadas a partir de la narrativa policial que en otras formaciones discursivas. Esa suma inestable de pasajes, entrecruzamientos, pliegues, intercambios, caracterizan al género como una inigualable esceno-grafía del sentido textual. Todos esos conceptos relacionados en un conjunto reunido por una insistencia sémica, que reitera una y otra vez la movilidad y la transacción, cuestionan y revisan las modalidades en las que los diferentes campos de la cultura desplazan y reelaboran estrategias y objetos que originariamente pertenecían a otros ámbitos.

É neste "entramado indecidible entre el metatexto y la intriga ficcional" que se constrói a escrita de Plata quemada no escopo da práxis narrativa de Piglia. É na "exhibición desaforada de la ficción como procedimiento" que se forma La pesquisa, reverberando a poética de Saer. O que nos faz voltar, mais uma vez, às marcas de uma aproximação ao gênero que não o define a partir de contingências da série histórica transformadas em dogmas, mas que o lê partindo de processos mais dinâmicos: as relações da ficção com a sociedade com o crime, a lei e a verdade - e a narrativa em segunda instância, ambas mescladas em procedimentos que se mesclam e se superpõem.

Quando Piglia afirma que, para ele, "el género policial ha funcionado como una estrategia narrativa fundada, básicamente, en la idea del relato como investigación” (2009b), fica clara a busca da verdade na prática da ficção - o que fica muitas vezes reiterado por outros ensaios, entrevistas e declarações do escritor. Saer, por sua vez, apresenta o problema de outra maneira, ao reivindicar a autonomia literária como portadora de sua própria verdade imanente: "la verdad no es necesariamente lo contrario de la ficción" (1997a, p. 11). O que une, de qualquer modo, as narrativas de Plata quemada e La pesquisa é a investigação do 
real $^{171}$, esteja ele onde estiver, caso ele de fato exista. A marca do gênero se manifesta como procedimento narrativo, mais do que como tema ${ }^{172}$.

Na investigação de La pesquisa, o narrador em segunda instância Pichón afirma que (LP, p. 17):

no ignoraban que una investigación difícil, que exigiese imaginación y perseverancia, tiempo y razonamiento, flexibilidad y obstinación, [...] que únicamente el comisario Morvan podía llevarla hasta el final y extraer de ella sean cuales fueran, las últimas consecuencias. Como en todo investigador auténtico, cualquiera fuese el campo al que la aplicara, la pulsión de verdad sobresalía en él. (grifos meus)

Realiza-se, então um jogo duplo na narrativa: a pulsão de verdade do detetive do gênero literário é extrapolada a qualquer campo e a investigação criminal prática ocorrida dentro da trama não prescinde da imaginação, própria da criação artística. Neste sentido, inclusive, aproxima-se o Morvan de Saer do Lönrot de Borges, em "La muerte y la brújula", que diz, em diálogo com o comissário Treviranus, durante a investigação de um crime (2000, p. 201):

- Posible, pero no interesante - respondió Lönnrot-. Usted replicará que la realidad no tiene la menor obligación de ser interesante. Yo le replicaré que la realidad puede prescindir de esa obligación, pero no las hipótesis.

A investigação da verdade, da verdade da ficção, da literatura, da história ou da sociedade perpassa todo o romance de Saer, nas histórias do Soldado Velho e do Soldado Jovem em "En las tiendas griegas", na história do próprio texto encontrado entre as coisas de Washington, na investigação do desaparecimento do Gato Garay, irmão de Pichón, nos tempos da ditadura - esta, ao fim, não realizada -, no questionamento das fontes na imprensa

\footnotetext{
171 Para Clemens Franken: "Además, había que considerar en la narrativa policial argentina la infaltable presencia de una búsqueda o pesquisa.” (2011, p. 99)

${ }^{172}$ Raymond Chandler já dizia, em "A simples arte de matar" que: "A história é a aventura deste homem [o detetive] na busca de uma verdade oculta" (2001, p. 86)
} 
do relato que Pichón narra aos amigos. A poética de Saer, representada no ato de fazer do questionamento da representação do real no literário o seu centro, se multiplica e reverbera, então, em toda a escrita de La pesquisa. Por isto, ao discutir o problema que se apresentava a ele na proposta de escrever um romance que participava do gênero policial - o que, com suas fórmulas e convenções, poderia transgredir sua própria práxis poética imperdoavelmente Saer acaba chegando à seguinte conclusão: "no solamente no transgredía nada, sino que más bien estaba operando por enésima vez el eterno retorno de lo idéntico. Sin darme cuenta, había cambiado caballos por viejecitas, y estaba escribiendo otra vez la misma novela de siempre" $" 173$ (1999, p. 158).

É possível notar, em procedimentos como este, o deslocamento do referente em direção à referência - marca da literatura moderna -, como aponta Roberto Ferro. Contudo, em suas observações, Ferro também ressalta no policial contemporâneo latino-americano a busca pela verdade no referente (2009, p. 232-3). A particularidade de cada prática poética se mostra, então, nos procedimentos narrativos que cada escritor emprega neste movimento. No caso de Piglia, por exemplo, é desenvolvida a ficção paranoica, a leitura do complô na sociedade e nos discursos que ela engendra (PIGLIA, 2009), uma forma singular de manifestação do gênero ${ }^{174}$. A profusão de vozes que circulam em Plata quemada é um emaranhado de verdades e simulações de verdade indistinguíveis e que acabam por se anular. A narrativa de Piglia, desta maneira, dá voz a alguns discursos marginais da sociedade, mas não lhes confere nenhum caráter de verdade inequívoca. Os discursos que se enfrentam com a ficção estatal são o cerne da narrativa no que representam de embate, de confrontação, e daí a ideia de ficção paranoica - “!También los paranoicos tienen enemigos!”, diz o pai do narrador de "En este país", conto que abre Prisión perpetua (PIGLIA, 1988, p. 11).

\footnotetext{
${ }^{173}$ Uma referencia a Nadie nada nunca, romance de 1980, clave na narrativa de Saer.

${ }^{174}$ Segundo Manuel Rud: "El género policial [...] agrega, en este sentido, un elemento singular; en su propia matriz constitutiva, como signo central e inevitable de participación genérica, la narrativa policial prevé un crimen, y las posibilidades de verosimilitud del relato están íntimamente ligadas a las preguntas que ese crimen despliega en el transcurso de los textos." (2001)
} 
Se para Piglia a ficção é uma maneira de atuar na realidade, ela se realiza enquanto uma ficção que denuncia outras ficções que circulam no meio social - em especial os discursos do Estado e do poder em geral ${ }^{175}$. Se para Saer a representação do real na fícção é uma virtual impossibilidade e a retórica da representação realista só uma retórica (PRIETO, 2006, p. 415), a ficção não tem, por outro lado, um estatuto de verdade menor que a realidade.

$\mathrm{Na}$ questão das representações dos tempos históricos e da memória, novamente procedimentos relacionados ao gênero policial ganham espaço nos romances. Saer, em artigo sobre Respiración artificial, de Piglia, afirma que (2006a, p. 145):

El punto de partida de toda novela es el presente de la escritura, y lo que transporta el texto narrativo son las pautas sensoriales, emocionales, intelectuales de ese presente y ninguna otra cosa, cualquiera sea la época pasada, presente o futura - que elija el relato para instalar su ficción.

Em outras palavras, a investigação no gênero e em La pesquisa e Plata quemada, sempre será uma investigação do que já ocorreu - mesmo que a trama se passe no futuro - a partir das repercussões no presente de uma experiência também já vivida. Os dois romances se passam em décadas anteriores - La pesquisa em meados dos anos oitenta e Plata quemada nos anos de 1965 e 66 -, mas são escritos e publicados nos anos noventa, a década do menemismo. O presente pulsa na visão de Saer do consumismo e da alienação reinante na descrição que faz Pichón das pessoas na rua (LP, p. 161):

Familias enteras, cargadas de criaturas y de paquetes, hacían cola frente a las cajas o, instalados alrededor de una mesa en bancos inamovibles atornillados al piso, comían menúes idénticos en platos y vasos de cartón, aprovechando el respiro de corta duración en medio de su fatigosa carrera entre la reproducción y el consumo. Previstos rigurosamente de antemano por cuatro o cinco instituciones petrificadas que se complementan mutuamente - la Banca, la Escuela, la Religión, la Justicia, la Televisión - como un autómata por el perfeccionismo obsesivo de su constructor, el más insignificante de

\footnotetext{
${ }^{175}$ E, neste ponto, a práxis poética de Piglia se aproxima da ideia de Siscar de que é necessário à literatura mesclar-se com os discursos do poder, "de modo a denunciar seus efeitos de censura, mantendo no horizonte uma ideia de democracia por vir". (2010, p. 39)
} 
sus actos y el más recóndito de sus pensamientos, a través de los que están convencidos de expresar su individualismo orgulloso, se repiten también, idénticos y previsibles, en cada uno de los desconocidos que cruzan por la calle $[\ldots]$

E o presente pulsa também na visão desencantada dos anos primeiros do pós-ditadura, nas culpas de Pichón y Tomatis, no apagamento da memória do Gato Garay e Elisa, desaparecidos durante os anos de terror e cuja lembrança parece não encontrar expressão em nenhum discurso possível, convertendo-se no indizível que a pesquisa não alcança ${ }^{176}$.

Já a trama de Plata quemada se passa antes dos regimes de exceção da Revolução Argentina (1966-73) e do Processo de Reorganização Nacional (1976-83), descontada a narrativa do epílogo. O presente menemista da escrita, entretanto, reverbera na história do dinheiro elevado a deidade, na violência gerada na desigualdade e nas perseguições políticas e sociais agravada cada vez mais com o passar dos anos. Do mesmo modo como em La pesquisa, também ecoa a denúncia do pensamento único imposto pelo discurso do poder (estatal e financeiro), mas disfarçado de lógica democrática e de livre mercado, porque "por primera vez en la historia era posible transmitir en vivo, sin censura, los visajes de los muertos en la batalla de la ley contra el crimen.” (PQ, p. 166, grifo meu). A referência brechtiana da epígrafe, neste contexto, soa como uma superconsciência irônica do romance, já que no campo diegético do texto, "surgió ahí [cuando se quema la plata] la idea de que el dinero es inocente, aunque haya sido resultante de la muerte y el crimen", a única fonte, para Brecht, do dinheiro justamente dos bancos. A investigação do passado, aqui, é o prólogo da derrocada do menemismo ultraliberal - arrastando consigo todo o país - nos anos que se seguiriam. O uso de uma vertente extremamente violenta do policial, então, parece coerente

\footnotetext{
176 "En el texto se alude a una tercera pesquisa, correspondiente a la diégesis, frustrada casi desde su origen, ella concierne al misterio relativo a la desaparición del Gato, hermano mellizo de Pichón, y Elisa. [...] En La pesquisa, a diferencia de lo que sucede con los otros dos enigmas, no se realizará intento alguno por dilucidar este misterio, el cual quedará, en contradicción con el código detectivesco, como un blanco y sólo se alude a 'los tiempos terribles de la desaparición del Gato y de Elisa', afirmación que sobrepasando el ámbito de primer plano, se proyecta valorativamente hacia el mundo mayor, denunciando lapidariamente la imposibilidad de acceder a la verdad. (SOLOTOREVSKY, 1998, p. 439)
} 
com a linguagem que o narrador do Epílogo atribui a Blanca Galeano: "lenguaje que sonaba hostil, como suele sonar el lenguaje cuando se lo usa para contar una derrota.” (PQ, p. 250).

De qualquer forma, hostil ou paradoxal, as linguagens de Plata quemada e La pesquisa configuram também as poéticas de Piglia e Saer, que, no fim das contas, apresentam até pontos de contato. Quando Saer dedica La pesquisa a Ricardo Piglia, a homenagem se estende também à conformação do texto, com suas vozes entrecruzadas, com suas vozes que remetem a outras narrativas que, por sua vez, remetem a outras em um movimento infinito. A voz do outro, central na poética de Piglia, é para Saer só mais uma impossibilidade de representar o real, ainda que não uma falsidade. Já no movimento contrário, é em Plata quemada que vemos momentos do desnudamento da farsa da representação - tão presente em Saer -, como na descrição de um gesto do comissário Silva - "algo demasiado rápido para ser simulado (según Renzi) y sin embargo demasiado consciente para ser enteramente natural" (PQ, p. 196) - ou na mescla da consciência deste com a de um dos bandidos (PQ, p. 199-200):

Por ejemplo, Mereles alias el Cuervo, le conocía el prontuario, se lo podía imaginar [...] Seguro que se pasaban la vida viendo películas de guerra y ahora actuaban como si fueran un comando suicida atrás de las líneas contrarias, en territorio extranjero, sorprendidos por los rusos en un departamento, en Berlín Oriental, del otro lado del Muro, rodeados, resistiendo hasta que llegaran a salvarlos, imaginaba, y se daba manija Mereles.

E mesmo no ato tão saeriano de por a nu a farsa da representação realista na literatura, Piglia não deixa de lado sua poética, na qual a ficção tem por obrigação denunciar as outras ficções geradas pelo poder político e econômico. Assim, quando é necessário sobrepor às narrativas oficias sobre um episódio da crônica policial ocorrido muitos anos antes uma nova narrativa outra - ou, melhor dizendo, narrativas outras -, Plata quemada o faz, mas, pela voz de Renzi, deixa entrever que a nova "versão dos fatos" não é a verdade ou a realidade, mas só mais uma das ficções que circulam nesta: "El cronista no sabe pero maneja varias hipótesis" 
(PQ, p. 136) - passagem na qual se explicita até o manejo que se faz das ficções sociais ou literárias.

Por fim, no reforço da autonomia literária que pode representar o gênero policial, no gesto explícito de narrar uma narrativa - e não uma ação que se pretende verdadeira, uma realidade simulada pela retórica - surge a figura do duplo. Nem tão evidente nos textos de Poe fundadores do gênero - ainda que mais em "A carta roubada" - o embate entre o detetive - e sua narrativa da investigação - e o criminoso - e sua narrativa do crime - se torna um elemento clave na concepção do gênero. Quando Borges faz com que se enfrentem Lönrot e o Dandy Scharlach, em "La muerte y la brújula", não subverte o gênero pelo triunfo do criminosos sobre o detetive, mas fazendo com que a narrativa da investigação não coincida com a narrativa do crime ao final, suplantando-a. É Dandy Scharlach que, ao revés, faz com que sua narrativa do crime coincida com a narrativa da investigação do detetive, derrotando-o.

Em La pesquisa e Plata quemada o duplo se aparta do embate clássico entre detetive e criminoso em movimentos diversos. Em um sentido, a figura do espelho nos dois romances pode servir a uma interpretação que corresponde à duplicação do real (ainda que ilusoriamente) pela ficção. Assim, a figura central de Plata quemada, o dinheiro - em si também uma ilusão - se vê duplicado pelo artifício, "la plata estaba amontonada en una especie de bargueño con un espejo que la duplicaba, una parva de guita sobre un hule blanco repetida, como una ilusión”. (PQ, p. 60-1). Em La pesquisa, Morvan, a quem vai tocar ser ao mesmo tempo detetive e criminoso, tampouco se reconhece no espelho - "Él sabía que él era él, Morvan, y sabía que estaba mirando la imagen de un hombre en el espejo, pero esa imagen era la de un desconocido" (LP, p. 174) - e isto porque a narrativa do detetive desconhece, à princípio, a do criminoso, o que é incontornável para que se configure o gênero.

Em outros sentidos, em La pesquisa o duplo detetive/criminoso clássico se desloca para um detetive (Morvan) que se desdobra em dois, assumindo os dois papeis e revelando 
uma realidade em que a lei e o crime se confundem; Soldi faz o papel de "espía doble" na casa de Julia na busca pela verdade do datilograma de Washington; Pichón tem medo de enfrentar "la comprobación directa de que el inconcebible ente repetido [...] se hubiese evaporado sin dejar rastro en el aire de este mundo" (LP, p. 137-8, grifo meu), como se uma duplicação do real que percebemos e que também é real - como a literatura - deixasse de existir. Em Plata quemada, são os dois bandidos (Dorda e Brignone) que agem como um em ambos os lados do Río de la Plata, e em ambos os lados são perseguidos.

Como última imagem a ser analisada aqui, fica a associação do duplo à cultura argentina pela dicotomia entre civilização e barbárie. Ainda que imprecisa, falsa ou manipuladora, sua presença, mesmo desfigurada ou reconfigurada, ainda se deixa ver nos debates sobre a identidade cultural do país. Assim, é notável perceber como a dicotomia "mocinho"/"bandido" mais cara aos exemplares mais maniqueístas, conservadores e esquemáticos do gênero policial é transgredida por Saer e Piglia. Em La pesquisa, além do que aponta Edgardo Dobry (2012), não só “Saer consiguió hacer de París la periferia y poner el centro en esa zona santafecina en que suceden o a la que tienden todas sus ficciones", como a narrativa coloca a barbárie dos crimes na Europa e a discussão intelectual sobre a autoria de um manuscrito no interior da Argentina - um jogo que não encobre o local do verdadeiro terror que sofreram os personagens. Já em Plata quemada, o pequeno burguês cosmopolita e o gaucho do interior estão ambos fora da lei, deslocados de sua própria nação, sobrevivendo da barbárie, enquanto a civilização é dominada pelo dinheiro, esse "inocente" dinheiro que não tem cheiro, não tem alma e não tem pátria. 


\section{Considerações finais}

Raymond Chandler, em “A simples arte de matar” (2001, p. 160-86), defende a ideia de que escrever uma boa história policial é tão difícil quanto escrever uma boa história de qualquer tipo. Entretanto, na feroz competição entre os romances na busca pela sobrevivência - de que fala Jorge Volpi, em "De parásitos, mutaciones y plagas" (2008, p. 23-37) -, o romance policial tem que arcar com a desvantagem do menosprezo de parte da crítica que vê no gênero só repetições, fórmulas e falta de criatividade. Para Chandler, no entanto, além do bom romance policial ser tão bom quanto qualquer outro romance, o que acontece, é que "as histórias de detetive, na média, provavelmente não são piores do que a média dos romances, mas não se vê, nunca, o romance médio. Porque ele não é publicado. A história de detetive média (ou pouca coisa acima da média) é publicada." (2001, p. 164) É claro que, em 1944 data da primeira aparição de "A simples arte de matar" -, Chandler provavelmente ainda não previa a proliferação do que Volpi chama de "romances praga", com sua qualidade literária bastante questionável, e uma estética "média" dos romances publicados tão pouco audaciosa e inovadora.

De qualquer maneira, o desafio permanece: escrever uma literatura policial em que os dois termos - "literatura" e "policial" - sejam levados a sério, pensados e problematizados, no escopo de uma escrita original. Entretanto, levar a sério o policial não significa abandonar os prazeres da escrita e da leitura. Muito ao contrário: se a escrita de La pesquisa pôde outorgar a Juan José Saer "el placer del abandono a una imaginación infantil” (SAER, 1999, p. 160), sobre "Recepción en Baker Street" - conto que é um prolongamento do romance, nas palavras do próprio autor - Saer afirma que: "Ese relato, en realidad, lo escribí porque, bueno, es un poco, un divertimento en cierto sentido." (SAER, 2004) A diversão do escritor se reflete na 
dos personagens que discutem a literatura e o gênero, partindo do relato policial de Pichón no romance, com a seriedade travestida de burla e descontração. Depois de contestar com ironia o relato do amigo Pichón em La pesquisa, querendo toda coisa "perfeita em seu gênero" (LP, p. 135), em "Recepción en Baker Street", Tomatis revela aos amigos como seria a história policial do último caso de Sherlock Holmes, se algum dia ele a escrevesse (SAER, 2006b, p. 88):

Si me decidiese a hacerlo, no lo escribiría en prosa: sería un largo poema narrativo en verso libre, con algunos pasajes rítmicos y ciertos finales de estrofa en versos regulares, alejandrinos probablemente, y rimas consonantes. De esa manera ocuparía en la historia de la literatura un lugar junto a Edipo rey, ya que Sófocles y yo seríamos los únicos dos autores que hubiésemos tratado en verso un enigma policial.

O debochado Tomatis parece, aqui, ignorar o relato "Três portugueses embaixo de um guarda-chuva (sem contar o morto)", de Rodolfo Walsh (2011, p. 213-8) - uma narrativa policial escrita em verso. Saer, no entanto, talvez tenha escrito, por sua vez, o primeiro relato do gênero a partir do condicional: a história contada por Tomatis - que está dentro do conto como a de Pichón está dentro do romance La pesquisa - leva, então, a "narrativa sobre a narrativa do crime", típica do policial, a conhecer uma nova vertente: a "narrativa sobre $o$ que seria a narrativa do crime”. Assim, é possível conjecturar que é na práxis narrativa de escritores como Saer - e também como Piglia - que parece se realizar certa observação de Bakhtin (2010, p. 364):

Os gêneros têm um significado particularmente importante. Ao longo de séculos de sua vida, os gêneros (da literatura e do discurso) acumulam formas de visão e assimilação de determinados aspectos do mundo. Para o escritor-artesão, os gêneros servem como chavão externo, já o grande artista desperta nele as potencialidades de sentido jacente. 
Ainda que esta tese não tenha tido a intenção de entrar no mérito do valor de Juan José Saer e Ricardo Piglia como "grandes artistas", ela buscou, sim, encontrar, em La pesquisa e Plata quemada, ao menos algumas "potencialidades de sentido jacente". A intenção de ler uma pluralidade de sentidos desejada na literatura de qualidade lembra a anedota que conta Peter Haining na Introdução da compilação Noir americano. Ao se encontrar com um fã de Raymond Chandler, este lhe diz: “- Não leio Chandler pela história - disse com um sorriso que falava de horas de prazer. - Leio pelas piadas!” (1998, p. 11) Acredito, então, que é possível, também, ler o policial não pelos crimes ou pelos óbvios truques de dedução, mas sim pela originalidade literária que, nos melhores exemplares do gênero, por ele pode se realizar. 


\section{Referências $^{177}$}

\section{Bibliografia de e sobre Juan José Saer}

SAER, Juan José. La buena literatura, en todo tiempo y lugar, es capaz de superar sus crisis a través de sus textos. Entrevista a Guillermo Mayr. Blog El jinete insomne, 08 de outubro de 2012. Disponível em: <http://eljineteinsomne2.blogspot.com.br/2012/10/juan-jose-saer-labuena-literatura-en_11.html>. Acesso em: 08 ago. 2014.

. La pesquisa. 3. ed. Buenos Aires: Seix Barral, 2008a. 208 p.

El entenado. 5. ed. Buenos Aires: Seix Barral, 2008b. 224 p.

Trabajos. Buenos Aires: Seix Barral, 2006a. 256 p.

Cuentos completos. 5. ed. Buenos Aires: Seix Barral, 2006b. 544 p.

Glosa. 2. ed. Buenos Aires: Seix Barral, 2006c. 240 p.

Entrevista a Margarita Merbilhaá. Orbis Tertius, La Plata: Centro de Estudios de Teoría y Crítica Literaria - UNLP, año IX, nº 10, 2004.

La ocasión. 2. ed. Buenos Aires: Seix Barral, 2003. 224 p.

El limonero real. Buenos Aires: Seix Barral, 2002. 176 p.

Nadie nada nunca. 2. ed. Buenos Aires: Seix Barral Biblioteca Breve, 2000a. 222 p.

. Sobre Literatura. Cuadernos de Recienvenido, São Paulo, Humanitas / FFLCH / USP, $n^{\mathrm{o}} 14$, p. 5-27, setembro, 2000 b.

. La narración-objeto. Buenos Aires: Seix Barral, 1999. 208 p.

. El concepto de ficción. Buenos Aires: Ariel, 1997a. 302 p.

. Las nubes. Buenos Aires: Seix Barral, 1997b. 240 p.

. Lo imborrable. Buenos Aires: Alianza, 1993. 100 p.

La mayor. Buenos Aires: Centro Editor de América Latina. 1982.

A literatura e as novas linguagens. In: FERNÁNDEZ MORENO, César (coordenação e introdução). América Latina em sua literatura. São Paulo: Perspectiva, 1979. p. 307-23.

\footnotetext{
${ }^{177}$ De acordo com Associação Brasileira de Normas Técnicas (ABNT) - NBR 6023.
} 
ABBATE, Florencia. "No existe el optimismo en la buena literatura" (entrevista a Juan José Saer). In: VIÑAS, David (dir.), CARBONE, Rocco \& OJEDA, Ana (comp.). De Alfonsín al menemato 1983-2001: literatura argentina siglo XX. Buenos Aires: Paradiso; Fundación Crónica General, 2010. p. 91-3.

AGUILLÓN-MATA, Sergio Alejandro. Notas a un Diálogo entre Juan José Saer y Ricardo Piglia. La Cabeza del Moro, Zacatecas, México, año 2, nº 6, p. 22-25, octubre de 2006. Disponível em: < http://aguillon-mata.com/2012/02/08/notas-a-un-dialogo-entre-juan-josesaer-y-ricardo-piglia/>. Acesso em: 12/05/2014.

BLAUSTEIN, Daniel. Estrategias narrativas en La pesquisa de Juan José Saer. Lengua y Literatura / Língua e Literatura / Language \& Literature, The Graduate Center, The City University of New York, v. 2, $\mathrm{n}^{\mathrm{o}} 2$ 2, 2007. Disponível em: < http://ojs.gc.cuny.edu/index.php/lljournal/article/view/174/249>. Acesso em: 05/05/2014.

CORBATTA, Jorgelina. Juan José Saer: arte poética y práctica literaria. Buenos Aires: Corregidor, 2005. $190 \mathrm{p}$.

CORRAL, Rosa (ed.). Entre Ficción y Reflexión: Juan José Saer y Ricardo Piglia. México D.F.: El Colegio de México, Centro de Estudios Lingüísticos y Literarios, 2007. 312 p.

DOBRY, Edgardo. Galaxia Saer. El País, Madrid, 17 de março de 2012. Suplemento Cultura. Disponível em: < http://cultura.elpais.com/cultura/2012/03/14/actualidad/1331725175_369605.html>. Acesso em: 10/05/2014.

GARRAMUÑO, Florencia. El entenado: tiempo y representación. In: Genealogías culturales - Argentina, Brasil y Uruguay en la novela contemporánea (1981-1991). Buenos Aires: Beatriz Viterbo, 1998. p. 104-12.

GRAMUGLIO, María Teresa. Lugar. La expansión de los límites. Actas del II Congreso Internacional "Cuestiones Críticas". Rosario: Centro de Estudios de Teoría y Crítica Literaria - FH y A-UNIR, 2009.

GUIÑAZÚ, Cristina. Los múltiples laberintos en La pesquisa de Juan José Saer. Ciberletras: Revista de crítica literaria y de cultura, Yale University, nº 21, 2009. Disponível em: < http://www.lehman.edu/faculty/guinazu/ciberletras/v21/guinazu.htm>. Acesso em: 05/05/2014.

INZAURRALDE, Gabriel. La ciudad violenta y su memoria: Novelas de violencia en el fin de siglo. 2007. 286 p. Tese de Doutorado. Proefschrift Universiteit Leiden, Leiden (Holanda), 2007.

JITRIK, Noé. Entre el corte y la continuidad: hacia una escritura crítica. Revista Iberoamericana, vol. LXVIII, nº 200, p. 729-736, Julio-Septiembre 2002.

LARSON, Erik. Politics, Epistemology and the Problems of Rationalism in La pesquisa. Letras Hispanas, Texas State University-San Marcos, v. 8, nº 1, p. 63-72, Spring 2012. 
LAURENT, Pénélope. Soldi, ¿un autor de ficción? - IN: EZQUERRO, Milagros; RAMOS IZQUIERDO, Eduardo (dir.); ROGER, Julien (éd.), Les Ateliers du Séminaire d'Amérique Latine, Université Paris-Sorbonne-Paris IV, n 4, Réécritures I, 2010. Disponível em: < http://www.crimic.paris-sorbonne.fr/actes/sal4/laurent.pdf>. Acesso em: 05/05/2014.

PEREIRA, Antonio Marcos. As três vidas de Juan José Saer. Trabalho apresentado no VII Congresso Brasileiro de Hispanistas, em Salvador-BA, em setembro de 2012.

PREMAT, Julio. Héroes sin atributos. Buenos Aires: Fondo de Cultura Económica, 2009. $277 \mathrm{p}$.

La dicha de Saturno: escritura y melancolía en la obra de Juan José Saer. Rosario: Beatriz Viterbo, 2002. 480 p.

QUEIROZ, Juliana Maia de. Enigma e duplicidade em La Pesquisa, de Juan José Saer. 2004. 142 p. Dissertação de Mestrado. UNICAMP, Campinas, 2004.

REALES, L.; PREMAT, J.; MONDRAGÓN, J.C. Crítica Cultural = Cultural Critique (Edição especial - Dossiê Juan José Saer), Palhoça: Ed. Unisul / Universidade do Sul de Santa Catarina, v.5, $\mathrm{n}^{\mathrm{o}} 2$, dezembro, 2010.

RIERA Gabriel. “Regia Victoria” o más acá del fantasma (Encuentros con lo real en La pesquisa). Revista Iberoamericana, University of Pittsburgh, v. LXXII, $\mathrm{n}^{\mathrm{o}} 215-216$, p. 41531, abril/septiembre 2006.

SOLOTOREVSKY, Myrna. La subversión del modelo policial: La pesquisa de Juan José Saer. Actas XIII Congreso AIH, Madrid, tomo 3, p. 435-40, julio de 1998.

SPERANZA, Graciela. Autobiografía, crítica y ficción: Juan José Saer y Ricardo Piglia. Boletín del Centro de Estudios de Teoría y Crítica Literaria, Rosario, nº 9, p. 90-103, diciembre, 2001.

TORRE, María Elena. En las huellas de Piglia y Saer: el policial entre la historia y el mito. Cuadernos del Sur. Letras, Bahía Blanca, $n^{\circ}$ 32-33, 2003. Disponível em: <http://bibliotecadigital.uns.edu.ar/scielo.php?script=sci_arttext\&pid=S166874262003000100016>. Acesso em: 28 jan. 2012.

Bibliografia de e sobre Ricardo Piglia

PIGLIA, Ricardo. Blanco nocturno. México D.F.: Anagrama, 2010.302 p.

Teoria do complô. Revista Serrote, São Paulo, Instituto Moreira Salles, nº 2, p. 97 111, julho, 2009a.

El género policial ha funcionado como una estrategia narrativa fundada en la idea del relato como investigación. Entrevista a Guillermo Mayr. Blog El jinete insomne. 12 de 
novembro de 2009(b). Disponível em: <http://eljineteinsomne2.

blogspot.com/2009/11/ricardo-piglia-genero-policial-ha.html>. Acesso em: 31 out. 2011.

La lengua de los desposeídos. La Nación, Buenos Aires, 19 de abril de 2008.

Suplemento Cultura.

El último lector. Barcelona: Anagrama, 2005. 192 p.

Formas breves. São Paulo: Companhia das Letras, 2004a. 120 p.

Roberto Arlt, una crítica de la economía literaria. In: Grupo de investigación de literatura argentina de la UBA (comp.). Ficciones Argentinas. Antología de lecturas críticas. Buenos Aires: Norma, 2004b. p. 55-71.

Respiración artificial. 2. ed. Buenos Aires: Seix Barral, 2003. 220 p.

. Crítica y ficción. Barcelona: Anagrama, 2001a. 228 p.

. Tres propuestas para el próximo milenio (y cinco dificultades). Revista Casa de las Américas, La Habana, $n^{\circ} 222$, p. 11-21, enero-marzo $2001 b$.

La memória ajena. PAYERAS GRAU, María \& FERNÁNDEZ RIPOLL, Luís

Miguel (coord.). Fin(es) de siglo y modernismo: Congreso Internacional Buenos Aires - La Plata - agosto 1996, 2 vol. Palma: Universitat de les Isles Balears, 2001c. p. 701-3.

Plata quemada. 8. ed. Buenos Aires: Planeta, 1998a. 254 p.

Cuentos morales. 2. ed. Buenos Aires: Planeta, 1998b. 186 p.

La ciudad ausente. 3. ed. Buenos Aires: Seix Barral, 1997. 170 p.

$5,1987$.

Borges y Gombrowicz. Espacios de crítica y producción, Buenos Aires, n ${ }^{\circ}$ 6. p. 13 -

Ideología y ficción en Borges. Punto de Vista, Buenos Aires, año 2, nº 5, p. 3-6, 1979.

La prolijidad de lo real. Punto de vista, Buenos Aires, año I, no 3, p. 26-28, 1978.

Clase media cuerpo y destino. Actual - Revista de la Universidad de Los Andes, Mérida (Venezuela), nº 6, p. 27-37, enero-abril, 1970.

AGUILLÓN-MATA, Sergio Alejandro. Notas a un Diálogo entre Juan José Saer y Ricardo Piglia. La Cabeza del Moro, Zacatecas, México, año 2, nº 6, p. 22-25, octubre de 2006.

Disponível em: < http://aguillon-mata.com/2012/02/08/notas-a-un-dialogo-entre-juan-josesaer-y-ricardo-piglia/>. Acesso em: 12/05/2014.

ALONSO, Diego. Las formas de la política y el estatuto de la verdad en las obras de Rodolfo Walsh y Ricardo Piglia. In: ORECHIA HAVAS, Teresa (Ed.). Homenaje a Ricardo Piglia. Buenos Aires: Catálogos, 2012. 
ARTEAGA, Alejandro. Una ficción paranoica: notas sobre Blanco Nocturno, de Ricardo Piglia. Casa del tiempo, Xochimilco (México), Universidad Autónoma Metropolitana, Vol. IV, época IV, nº 44, p. 63-6, Junio, 2011.

AVELAR, Idelber. Para un Glosario de Ricardo Piglia. Revista Crítica Cultural, Palhoça, Santa Catarina, vol. 2, $\mathrm{n}^{\mathrm{o}}$ 1, jul./dez. 2007. Disponível em:

<http://www3.unisul.br/paginas/ensino/pos/linguagem/critica/0201/04.htm>. Acesso em: 28 jan. 2012.

BERG, Edgardo. El gabinete del doctor Caligari: Ricardo Piglia y Sergio Chejfec como críticos. Revista Grumo, Buenos Aires - Río de Janeiro, nº 7/8, p. 30-35, diciembre de 2008a.

Asesinos por naturaleza: sobre Plata quemada de Ricardo Piglia (segunda reflexión). CELEHIS - Revista del Centro de Letras Hispanoamericanas, Mar del Plata, Argentina, año 10, $n^{\mathrm{o}} 13$, p. 95-109, 2001.

CORRAL, Rosa (ed.). Entre Ficción y Reflexión: Juan José Saer y Ricardo Piglia. México D.F.: El Colegio de México, Centro de Estudios Lingüísticos y Literarios, 2007. 312 p.

FORNET, Jorge. (org.) Ricardo Piglia. Bogotá: Fondo Editorial Casa de las Américas / Instituto Caro y Cuervo, 2000. 318 p.

GARCÍA, Germán. Plata quemada o los nombres impropios. Virtualia: Revista digital de la Escuela de Orientación Lacaniana, Buenos Aires, $\mathrm{n}^{\circ}$ 1, abril, 2001. Disponível em: < http://www.eol.org.ar/virtualia/001/notas/index-001.html >. Acesso em: 25 jan. 2011.

GARIBOTTO Verónica y GÓMEZ, Antonio. Respiración artificial y el programa de refundación del campo cultural argentino. Revista Iberoamericana, vol. LXXV, ${ }^{\circ}$ 226, p. 229-242, Enero-Marzo 2009.

GARZÓN, Raquel. Ricardo Piglia: La épica de la novela policial. Clarín, Buenos Aires, 07 de agosto de 2010. $\tilde{N}$ - Revista de Cultura. Disponível em: <

http://edant.revistaenie.clarin.com/notas/2010/08/07/_-02206991.htm>. Acesso em: 10/05/2014.

GONZÁLEZ SAWCZUK, Susana. Ficción y crítica en la obra de Ricardo Piglia. Medellín: La Carreta Editores, 2008. 204 p.

HENRÍQUEZ, Pablo Unda. La falsa autobiografía como recurso para la reconstrucción de la experiencia en Plata quemada de Ricardo Piglia. Taller de Letras, Santiago de Chile, Pontificia Universidad Católica de Chile, n 42, p. 107-115, 2008.

INZAURRALDE, Gabriel. La ciudad violenta y su memoria: Novelas de violencia en el fin de siglo. 2007. 286 p. Tese de Doutorado. Proefschrift Universiteit Leiden, Leiden (Holanda), 2007.

MILREU, Isis. O que é roubar um banco comparado com fundá-lo? - De Brecht a Piglia. Revista Rascunhos Culturais, Coxim/MS, v.1, nº 1, p. 181-90, jan./jun.2010.

PEREIRA, Maria Antonieta. Ricardo Piglia y sus precursores. Buenos Aires: Corregidor, 2001. 270 p. 
PÉRSICO, Adriana Rodríguez. Las huellas del género: sobre Blanco nocturno de Ricardo Piglia. In: ANTELO, Raúl \& REALES, Liliana (org.) Argentina: texto tempo movimento. Ilha de Santa Catarina: Letras Contemporâneas, 2011. p. 80-91.

. (org.). Ricardo Piglia: una poética sin límites. Pittsburg: Instituto Internacional de Literatura Iberoamericana / Universidad de Pittsburg, 2004. 340 p.

PREMAT, Julio. Héroes sin atributos. Buenos Aires: Fondo de Cultura Económica, 2009. $277 \mathrm{p}$.

SCHOO, Ernesto. Calidoscopio narrativo. La Nación, Buenos Aires, 1 de agosto de 1997. Suplemento Cultura. Disponível em: < http://www.lanacion.com.ar/213922-calidoscopionarrativo>. Acesso em: 05/05/2014.

SELNES, Gisle. Parallel Lives: Heterotopia and Delinquency in Piglia's Plata Quemada. Ciberletras: Revista de crítica literaria y de cultura, New York City, University of New York, $\mathrm{n}^{\mathrm{o}}$ 15, julio, 2006. Disponível em:

<http://www.lehman.cuny.edu/ciberletras/v15/selnes.html>. Acesso em: 20 jan. 2011.

SPERANZA, Graciela. Autobiografía, crítica y ficción: Juan José Saer y Ricardo Piglia. Boletín del Centro de Estudios de Teoría y Crítica Literaria, Rosario, nº 9, p. 90-103, diciembre, 2001.

TORRE, María Elena. En las huellas de Piglia y Saer: el policial entre la historia y el mito. Cuadernos del Sur. Letras, Bahía Blanca, $n^{0}$ 32-33, 2003. Disponível em: $<$ http://bibliotecadigital.uns.edu.ar/scielo.php?script=sci_arttext\&pid=S166874262003000100016>. Acesso em: 28 jan. 2012.

Bibliografia de narrativa policial

ARLT, Roberto. Armadilha mortal. Trad. Sergio Faraco. Porto Alegre: L\&PM, 1997. 90 p.

BLOCK, Lawrence. O pecado dos pais. Trad. José Almino. São Paulo: Companhia das Letras, 2002. $168 \mathrm{p}$.

BOILEAU, Pierre \& NARCEJAC, Thomas. As diabólicas. Trad. Pedro Cavalcanti. Rio de Janeiro: Globo, 1987a. 168 p.

Um retiro macabro. Trad. Wagner Cardoso. Rio de Janeiro: Globo, 1987b. 164 p.

BORGES, Jorge Luis. La muerte y la brújula. In: Ficciones. Buenos Aires: Emecé, 2000. p. 197-220.

BORGES, Jorge Luis e BIOY CASARES, Adolfo. Seis problemas para dom Isidro Parodi. Duas fantasias memoráveis. Trad. Maria Paula Gurgel Ribeiro. São Paulo: Globo, 2008. 
BURNETT, W.R. O pequeno César. 2 ed. Trad. Monteiro Lobato. Rio de Janeiro: Civilização Brasileira, 1961. 214 p.

CAIM, James M. Indenização em dobro. Trad. Sérgio Flaksman. São Paulo: Companhia das Letras, 2007. 136 p.

O destino bate a sua porta. Trad. Celso Nogueira. São Paulo: Companhia das Letras, $1998.132 \mathrm{p}$. $240 \mathrm{p}$.

A mulher do mágico. Trad. José Romero Antonialli. São Paulo: Brasiliense, 1987.

CAMILLERI, Andrea. A paciência da aranha. Trad. Joana Angélica d'Ávila Melo. Rio de Janeiro: Record, 2011a. 237 p. 2011b. 220 p.

A lua de papel. 2 ed. Trad. Joana Angélica d’Ávila Melo. Rio de Janeiro: Record, . O ano-novo de Montalbano. Trad. Joana Angélica d'Ávila Melo. Rio de Janeiro: Record, 2009a. 285 p.

. O medo de Montalbano. Trad. Joana Angélica d'Ávila Melo. Rio de Janeiro: Record, 2009b. 300 p. 2008. 277 p.

O cão de terracota. Trad. Joana Angélica d’Ávila Melo. Rio de Janeiro: BestBolso, 2007. $142 \mathrm{p}$.

A forma da água. 3 ed. Trad. Joana Angélica d’Ávila Melo. Rio de Janeiro: Record, $222 \mathrm{p}$.

. Guinada na vida. Trad. Joana Angélica d'Ávila Melo. Rio de Janeiro: Record, 2005.

Um mês com Montalbano. Trad. Joana Angélica d'Ávila Melo. Rio de Janeiro: Record, 2002. 336 p. 2000. 224 p.

O ladrão de merendas. Trad. Joana Angélica d'Ávila Melo. Rio de Janeiro: Record,

CAMMILERI, Andrea \& LUCARELLI, Carlo. Água na boca. Trad. Joana Angélica d'Ávila Melo. Rio de Janeiro: Bertrand Brasil, 2013. 108 p.

CHANDLER, Raymond. O longo adeus. Trad. Flávio Moreira da Costa. Porto Alegre: L\&PM, 2007. 384 p.

Armas no Cyrano’s e outras histórias. Trad. Beatriz Viégas-Faria. Porto Alegre: L\&PM, 2001. 188 p.

. Adeus, minha adorada. Trad. Newton Goldman. São Paulo: Brasiliense, 1986a. 250

p. 
. O assassino à chuva e outras histórias. Trad. Carlos Leite. Porto: Edições

Afrontamento, 1986b. 202 p.

CHASE, James Hadley. Um trunfo a mais. Trad. A. B. Pinheiro Lemos. Rio de Janeiro: Record, 1971. 176 p.

CHesterton, G. K. A inocência do Padre Brown. Vários tradutores (org. Beatriz ViégasFaria). Porto Alegre: L\&PM, 2011. 256 p.

A sabedoria do Padre Brown. Trad. Edílson Alkmin Cunha. Rio de Janeiro: Graal, 1986. $256 \mathrm{p}$.

CHRISTIE, Agatha. Cai o pano. Trad. Clarice Lispector. Rio de Janeiro: Nova Fronteira, 2009. 217 p. 2003. $202 \mathrm{p}$.

O misterioso caso de Styles. Trad. A. B. Pinheiro Lemos. Rio de Janeiro: Record,

COLLINS, Wilkie. A pedra da lua. Trad. F. Rangel. Rio de Janeiro: Record, 2001. 688 p.

CONAN DOYLE, Arthur. Sherlock Holmes, v.5: Histórias de Sherlock Holmes. Edição definitiva e comentada (edição e notas de Leslie Klinger). Volume 5. Trad. Maria Luiza X. de A. Borges. Rio de Janeiro: Zahar, 2011a. 440 p.

Sherlock Holmes, v.4: $O$ último adeus de Sherlock Holmes. Edição definitiva e comentada (edição e notas de Leslie Klinger). Volume 4. Trad. Maria Luiza X. de A. Borges. Rio de Janeiro: Zahar, 2011b. 278 p.

. Sherlock Holmes, v.3: A volta de Sherlock Holmes. Edição definitiva e comentada (edição e notas de Leslie Klinger). Volume 3. Trad. Maria Luiza X. de A. Borges. Rio de Janeiro: Zahar, 2011c. 452 p.

Sherlock Holmes, v.2:.As memórias de Sherlock Holmes. Edição definitiva e comentada (edição e notas de Leslie Klinger). Volume 2. Trad. Maria Luiza X. de A. Borges. Rio de Janeiro: Zahar, 2010a. 406 p.

Sherlock Holmes, v.1: As aventuras de Sherlock Holmes. Edição definitiva e comentada (edição e notas de Leslie Klinger). Volume 1. Trad. Maria Luiza X. de A. Borges. Rio de Janeiro: Zahar, 2010b. 484 p. $192 \mathrm{p}$.

Um estudo em vermelho. Trad. Rosaura Eichenberg. Porto Alegre: L\&PM, 2010c,

COSTA, Flávio Moreira da. Modelo para morrer. Rio de Janeiro: Record, 1999. 192 p.

ELLROY, James. Los Angeles cidade proibida. Trad. Alves Calado. Rio de Janeiro: BestBolso, 2011. 496 p.

FAULKNER, William. Lance mortal. Trad. Wladir Dupont. São Paulo: Saraiva/Benvirá, 2012. $256 \mathrm{p}$.

FIGUEIREDO, Rubens. Essa maldita farinha. 2 ed. Rio de Janeiro: Record, 1999. 252 p. 
FONSECA, Rubem. Romance negro e outras histórias. 9 ed. Rio de Janeiro: Nova Fronteira, 2011. 248 p.

O caso Morel. 6 ed. Rio de Janeiro: Agir, 2010. 232 p.

GARCIA-ROZA, Luiz Alfredo. O silêncio da chuva. 2 ed. São Paulo: Companhia das Letras, 2002. $264 \mathrm{p}$.

GOODIS, David. Sexta-feira negra. 2 ed. Trad. Eduardo Bueno. Porto Alegre: L\&PM, 2007.200 p.

Atire no pianista. Trad. Ubirajara Forte. São Paulo: Brasiliense, 1985. 216 p.

A lua na sarjeta. Trad. Aldo Bocchini Neto. São Paulo: Brasiliense, 1984. 172 p.

HAINING, Meter (comp.). Noir americano: uma antologia do crime de Chandler a

Tarantino. Trad. Ronaldo Sergio de Biasi. 2 ed. Rio de Janeiro: Record, 1998. 416 p.

HAMMETT, Dashiell. O falcão maltês. Trad. Rubens Figueiredo. São Paulo: Companhia das Letras, 2001a. 294 p.

Cidade pesadelo (trad. Heloísa Seixas); Detetive de plantão (trad. Heloísa Seixas); Um homem chamado Spade (trad. Luiz Antonio Aguiar). In: Janeiro / São Paulo: Record, 2001b. p. 21-70; 71-87; 375-414. Tiros na noite. Rio de

. Continental Op. Trad. Ruy Jungmann. São Paulo: Companhia das Letras, 1988. 294

p.

Safra vermelha. 2 ed. Trad. Marcos A. P. Ribeiro. São Paulo: Brasiliense, 1987. 280

p.

A chave de vidro. Trad. Sílvia Mendes Cajada. Lisboa: Livros do Brasil, [s/d]. 230

p.

HEMINGWAY, Ernest. Os pistoleiros. In: ___ Contos. vol, 2. Tradução de José J. Veiga. Rio de Janeiro: Bertrand Brasil, 2006. p. 182-194.

HIGHSMITH, Patrícia. O sol por testemunha. Trad. Aulyde Soares Rodrigues. Rio de Janeiro: Nova Fronteira, 1981.254 p.

HIMES, Chester. Um jeito tranqüilo de matar. Trad. Celina Falk Cavalcante. Porto Alegre: L\&PM, 2008. 200 p.

A maldição do dinheiro. Trad. Edmundo Barreiros. Porto Alegre: L\&PM, 2007. 206

p.

O Harlem é escuro. Trad. Celina Falk Cavalcante. Porto Alegre: L\&PM, 2006. 255

p. 1986. $220 \mathrm{p}$.

A travessura de Casper Holmes. Trad. Álvaro Hattnher. São Paulo: Brasiliense, 
LEROUX, Gaston. O mistério do quarto amarelo. Trad. Duda Machado. São Paulo: Ática, 2004. 208 p.

MACDONALD, Ross. Cidade corrompida. Trad. Sylvio Gonçalves. Rio de Janeiro: Record, 2000. 224 p. $262 \mathrm{p}$.

Dinheiro sujo. Trad. Cecília C. Bartalotti. São Paulo: Companhia das Letras, 1989.

McBAIN, Ed. A última dança: um romance no $87^{\circ}$ DP. Trad. Luiz Antonio Aguiar. Rio de Janeiro: Record, 2003. 288 p.

Sangue e gelo: o mistério da dançarina loura. Trad. Marcos Santarrita. Rio de Janeiro: Edições Graal, 1986. 392 p.

McCOY, Horace. Mas não se mata cavalo? Trad. Érico Veríssimo. São Paulo: Abril Cultural, 1982. $156 \mathrm{p}$.

NOGUEIRA, Joaquim. Vida pregressa. São Paulo: Companhia das Letras, 2003. 374 p.

ONETTI, Juan Carlos. A longa história; A face da desgraça; Presencia. In: .47

Contos de Juan Carlos Onetti. Trad. Josely Vianna Baptista. São Paulo: Companhia das Letras, 2006. p. 116-125; 198-223; 373-379.

PADURA, Leonardo. La neblina del ayer. Barcelona: Tusquets, 2009. 358 p.

POE, Edgar Allan. A carta roubada; O homem da multidão. In: Contos. Trad. José

Paulo Paes. São Paulo: Cultrix, 1986. p. 23-40; 131-139. $1028 \mathrm{p}$.

Complete tales and poems of Edgar Allan Poe. Londres: Penguin Books, 1982.

Os crimes da Rua Morgue; O mistério de Marie Rogêt. In: Os crimes da Rua Morgue. Trad. Aldo Della Nina. São Paulo: Saraiva, 1961. p. 1-37; 38-90;

PUIG, Manuel. The Buenos Aires Affair. 3 ed. Trad. Glória Rodríguez. Rio de Janeiro: José Olympio, 2005. 256 p.

SANTIS, Pablo de. O enigma de Paris. Trad. Maria Alzira Brum Lemos. São Paulo: Planeta, 2007. $256 \mathrm{p}$.

SCIASCIA, Leonardo. O mar cor de vinho; Filologia; Bangue-bangue de máfia. In:

O mar cor de vinho. Trad. Silvia La Regina. São Paulo: Berlendis \& Vertecchia, 2001. p. 4069; 100-107; 143-147.

O dia da coruja. Trad. Mario Fondelli. Rio de Janeiro: Rocco, 1995. 114 p.

SIMENON, Georges. O cachorro amarelo. Trad. Eduardo Brandão. São Paulo: Companhia das Letras, 2014. 136 p. 1983. 192 p.

Maigret e seu morto. Trad. Áurea Weissenberg. Rio de Janeiro: Nova Fronteira, 
1979. $122 \mathrm{p}$.

A noite da encruzilhada. Trad. Raul de Sá Barbosa. Rio de Janeiro: Nova Fronteira,

STOUT, Rex. Milionários demais. Trad. Álvaro Hattnher. São Paulo: Companhia das Letras, 1999. $308 \mathrm{p}$.

$230 \mathrm{p}$.

Mulheres demais. Trad. Celso Nogueira. São Paulo: Companhia das Letras, 1993.

$224 \mathrm{p}$.

Cozinheiros demais. Trad. Celso Nogueira. São Paulo: Companhia das Letras, 1991.

THOMPSON, Jim. O assassino em mim. Trad. Luana Freitas. São Paulo: Planeta, 2005. 238 p.

VÁZQUEZ MONTALBÁN, Manuel. O labirinto grego. Trad. Bernardo Joffily. Companhia das Letras, 1992. 158 p.

VERÍSSIMO, Luis Fernando. Borges e os orangotangos eternos. São Paulo: Companhia das Letras, 2000. $134 \mathrm{p}$.

O clube dos anjos. Rio de Janeiro: Objetiva, 1998. 132 p.

WALSH, Rodolfo. A máquina do bem e do mal e outros contos. Trad. Sérgio Molina e Rubia Prates Goldoni. São Paulo: Editora 34, 2013. 240 p.

Variações em vermelho e outros casos de Daniel Hernández. Trad. e posfácio

Sérgio Molina e Rubia Prates Goldoni. São Paulo: Editora 34, 2012. 240 p.

\section{Bibliografia geral}

ADORNO, Theodor W. Posição do narrador no romance contemporâneo. In: Notas de Literatura I. Trad. Jorge de Almeida. São Paulo: Duas Cidades / Ed. 34, 2003. p. 55-63.

Engagement. In: Notas de Literatura. Trad. Celeste Aida Galeao e Idalina Azevedo da Silva. Rio de Janeiro: Tempo brasileiro, 1973.p. 51-71.

ARFUCH, Leonor. Semiótica y política. In: Crítica cultural entre política y poética. Buenos Aires: Fondo de Cultura Económica, 2008. p. 91-103.

ALBUQUERQUE, Paulo de Medeiros e. O mundo emocionante do romance policial. Rio de Janeiro: Francisco Alves, 1979. 510 p.

AMAR SÁNCHEZ, Ana María. Ley y canon en el género. El policial de fin de siglo. In: PAYERAS GRAU, María \& FERNÁNDEZ RIPOLL, Luís Miguel (coord.). Fin(es) de siglo y modernismo: Congreso Internacional Buenos Aires - La Plata - agosto 1996. 2 vol. Palma: Universitat de les Isles Balears, 2001. p. 729-32. 
Vínculos, usos y traiciones. La cuestión teórica; El crimen a veces paga. Policial latinoamericano en el fin de siglo. In: . Juegos de seducción y traición. Literatura y cultura de masas. Rosario: Beatriz Viterbo, 2000. p. 11-44; 45-83.

ANTELO, Raúl. Crítica e ficção: uma perspectiva hispano-brasileira. In: (ed.). Crítica e ficção. Florianópolis: Núcleo de Estudos Literários e Culturais. Universidade Federal de Santa Catarina, 2005. P. 9-50.

ARISTÓTELES. Arte poética. Trad. Pietro Nassetti. São Paulo: Martin Claret, 2003. 150 p. [s/d]. $358 \mathrm{p}$.

Arte retórica. Trad. Antônio Pinto de Carvalho. Rio de Janeiro: Edições de Ouro,

ARLT, Roberto. El juguete rabioso. . Gualeguaychú: Colemia, 2008. 156 p.

Los siete locos. Gualeguaychú: Colemia, 2007. 206 p.

Aguafuertes porteñas. 11. ed. Buenos Aires: Losada, 2002a. 190 p.

El jorobadito. 8. ed. Buenos Aires: Losada, 2002b. 186 p.

AVELAR, Idelber. Cânone Literário e Valor Estético: notas sobre um debate de nosso tempo. Revista Brasileira de Literatura Comparada, São Paulo, nº15, p. 113-50, 2009.

Alegorias da derrota: A ficcção pós-ditatorial e o trabalho do luto na América Latina. Belo Horizonte: Ed. UFMG, 2003.303 p.

BAKHTIN, Mikhail. Estética da criação verbal. 5.ed. Trad. Paulo Bezerra. São Paulo: WMF Martins Fontes, 2010. 476 p.

Questões de Literatura e de Estética (A Teoria do Romance). 5.ed. Trad. Aurora Fornoni Bernardini e outros. São Paulo: Annablume / Hucitec, 2002. 440 p.

BARBOZA, Martha. Novelas negras argentinas: entre lo propio y lo ajeno. Espéculo. Revista de estudios literarios. Madrid, Universidad Complutense de Madrid, año XIII, $\mathrm{n}^{\circ}$ 38, marzo / junio, 2008. Disponível em: <

http://pendientedemigracion.ucm.es/info/especulo/numero38/negarge.html>. Acesso em: 10 mai. 2014.

BARTHES, Roland. Una problemática del sentido.In: Variaciones sobre la escritura. Trad. Enrique Folch González. Buenos Aires: Paidós. 2007. p. 43-55.

O grau zero da escrita. 2. ed. Trad. Mario Laranjeira. São Paulo: Martins Fontes, 2004a. 225 p.

O rumor da língua. 2. ed. Trad. Mario Laranjeira. São Paulo: Martins Fontes, 2004b. 462 p.

BENJAMIN, Walter. A crise do romance; Que é o teatro épico? In: Magia e técnica, arte e política: ensayos sobre literatura e história da cultura. 7 ed. Trad. Serio Paulo Rouanet. São Paulo: Brasiliense, 1994. p. 54-60; 78-90.. 
BERG, Edgardo. La escuela del crimen. Espéculo. Revista de estudios literarios, Madrid, Universidad Complutense de Madrid. n ${ }^{\circ}$ 38, mar/jun. 2008b. Disponível em:

<http://www.ucm.es/ info/especulo/numero38/escrimen.html>. Acesso em 16/08/2011.

BERRUTTI, María Helena \& DiMARCO, José. Novelas que abordan el pasado: una lectura transversal de la narrativa argentina entre 1969 y 1995. Córdoba: Universidad Nacional de Río Cuarto, 2006. 140 p.

Bíblia de Jerusalém. São Paulo: Paulinas, 1980.

BOLAÑO, Roberto. Los detectives salvajes. 20 ed. Barcelona: Anagrama, 2011. 616 p.

BOLLE, Willi. A metrópole: palco do flâneur. In: Fisiognomia da metrópole moderna. São Paulo: Edusp, 1994. p. 366-400.

BOOTH, Wayne C. A retórica da ficção. Trad. Maria Teresa H. Guerreiro. Lisboa: Arcadia, 1980. $443 \mathrm{p}$.

BORGES, Jorge Luis. Historia universal de la infamia. Buenos Aires: Emecé, 2005. 160 p.

Leyes de la narración policial; Edgar Allan Poe. In: Textos recobrados.

1931-1955. Buenos Aires: Emecé, 2001. p. 36-9; 263-5.

Ficciones. Buenos Aires: Emecé, 2000. 284 p.

O conto policial. Trad. Maria Rosinda Ramos da Silva. In:

Obras completas. vol. IV. 1975-1988. São Paulo: Globo, 1999a. p. 220-230.

Los laberintos policiales y Chesterton. In: Borges en Sur. 1931-1980.

Buenos Aires: Emecé, 1999b. p. 126-129.

El Aleph. Madrid: Alianza, 1997a. 204 p.

Chesterton, narrador policial; Roger Caillois: 'le roman policier'. In:

Ficcionario: una antología de sus textos. México D.F.: Fondo de Cultura Económica, 1997b. p. 119-20; 191-2.

El escritor argentino y la tradición. In: Obras completas. Buenos Aires: Emecé, 1977. p. 128-37.

BOURNEUF, Roland \& OUELLET, Réal. O universo do romance. Trad. José Carlos Seabra Pereira. Coimbra: Livraria Almedina, 1976. 336 p.

CABELLO, Ángel Gregorio. Realismo crítico y novela negra. Revista Latinoamericana de Ensayo, Santiago de Chile, año XV, noviembre, 2007. Disponível em: < http://critica.cl/literatura/realismo-critico-y-novela-negra>. Acesso em 10 mai. 2014.

CAMPOS, Haroldo de. Ruptura dos gêneros na literatura latino-americana. In: FERNÁNDEZ MORENO, César (coord. e introd.). América Latina em sua literatura. São Paulo: Perspectiva, 1979. p. 281-305. 
CARBONE, Rocco \& OJEDA, Ana. Estallidos: De la democracia a la depresión. In: VIÑAS, David (dir.), CARBONE, Rocco \& OJEDA, Ana (comp.). De Alfonsín al menemato 19832001: literatura argentina siglo XX. Buenos Aires: Paradiso; Fundación Crónica General, 2010. p. 11-56.

CARDOZO, Mauricio Mendonça. Tradução e o trabalho de relação: uma poiética da tradução. In: PIETROLUONGO, Márcia A. (org.) O trabalho da tradução. Rio de Janeiro: Contracapa, 2009. p. 181-8.

CHANDLER, Raymond. A simples arte de matar. In: . Armas no Cyrano's e outras histórias. Porto Alegre: L\&PM, 2001. p. 160-86.

CHESTERTON, G. K. Como escrever uma história de detetive. In: . A inocência do Padre Brown. Trad. Carlos Ancêde Nougué. Rio de Janeiro: Sétimo Selo, 2006. p. 297-303.

A Defence of Detective Stories (from The defendant). In: VV.AA. Essays of Today. London: George G. Harrap \& Co., 1923. p. 226-9. Disponível em: < https://archive.org/stream/essaysoftoday00prituoft\#page/226/mode/2up>. Acesso em 12/05/ 2014.

CHKLOVSKI, Viktor. A construção da novela e do romance. In: EIKHENBAUM, Boris et alii. Teoria da literatura: formalistas russos. Trad. Ana Mariza Ribeiro e outros. Porto Alegre: Ed. Globo, 1971. p. 205-26.

COBAS, Alberto Costas. Una crónica del caso Liberaij. Entrevista a Fernando Tetes. Espectador. 01 de junho de 2000. Disponível em: <http://www.espectador.com/text/rompe/rpc06012.htm>. Acesso em: 24 mar. 2014.

COMPAGNON, Antoine. O demônio da teoria: Literatura e senso comum. 2 ed. Trad. Cleonice Paes Barreto Mourão; Consuelo Fortes Santiago. Belo Horizonte: Ed. UFMG, 2010. 292. p.

O trabalho da citação. Trad. Cleonice Paes Barreto Mourão. Belo Horizonte: Ed. UFMG, 1996. 176. p.

CORTÁZAR, Julio. América Latina: exilio y literatura. In: Obra Crítica/3, Saúl Sosnowski (org.). Madrid, Alfaguara, 1994. p. 163-80.

CROCE, Benedetto. Os gêneros literários e artísticos e as categorias estéticas. In:

Breviário de Estética / Aesthetica in nuce. Trad. Rodolfo Ilari Jr. São Paulo: Ática, 2001. p. 175-7.

DANTE ALIGHIERI. A divina comédia. Trad. J. P. Xavier Pinheiro. São Paulo: Editor Folco Masucci, 1965. 416 p.

DE QUINCEY, Thomas. Do assassinato como uma das belas artes. Trad. Henrique de Araújo Mesquita. Porto Alegre: L\&PM, 1985.

DELANEY, Juan José. Sobre los orígenes de la literatura fantástica, policial e de ficción científica en la Argentina. In: JITRIK, Noé (dir.). Historia crítica de la literatura argentina V. Buenos Aires: Emecé, 2006. p. 607-34. 
DERRIDA, Jacques. La ley del género. Trad. Gonzalo Jíménez M. y Bruno Mazzoldi. In: . La ley del género / Retóricas de la droga. Cali / Pasto (Colombia): Elipsis ocasionales: 1990. p. 3-41.

ECHEVERRÍA, Esteban. La cautiva / El matadero - Prólogo y notas de Carlos Dámaso Martínez. 31. ed. Buenos Aires: Losada, 2000. 150 p.

ECO, Umberto. Ironia intertextual e níveis de leitura. In: Sobre a literatura. Trad. Eliana Aguiar. Rio de Janeiro: Record, 2003. p. 199-218.

A mensagem estética. In: A estrutura ausente. Trad. Pérola de Carvalho. 7 ed. São Paulo: Perspectiva, 1991. p. 51-71.

EIKHENBAUM, Boris. Sobre a teoria da prosa. In: et alii. Teoria da literatura: formalistas russos. Trad. Ana Mariza Ribeiro e outros. Porto Alegre: Ed. Globo, 1971. p. 15768 .

FABRY, Geneviève. Presentación. In: FABRY, Geneviève \& LOGIE, Ilse (dir.). La literatura argentina de los años 90. Amsterdam/New York: Rodopi, 2003. p. 7-14.

FAUSTO, Boris \& DEVOTO, Fernando J. Brasil e Argentina: Um ensaio de história comparada (1850-2002). 576 p. São Paulo: Ed. 34, 2004. 576 p.

FERNÁNDEZ, Macedonio. Museo de la novela de la eterna (Primera novela buena). 2. ed. Buenos Aires: Corregidor, 2010. 272 p.

FERNÁNDEZ, Nancy. Cuerpo y violencia en la literatura argentina. In: BERG, Edgardo (comp.). Papeles en progreso. Mar del Plata: UNMDP / Digital Print, 2010. p. 37-58.

FERRO, Roberto. Ciencias morales de Martín Kohan: una pedagogía de la vigilância mal e escrita literária. Contracorrente: revista de estudos literários, Manaus, Universidade do Estado do Amazonas, v. 2, n 2, "Narrativas da Violência", p. 159-71, 2011.

La narrativa policial latinoamericana: una encrucijada de senderos que se bifurcan y se intersectan. In: De la literatura y los restos. Buenos Aires: Liber, 2009. p. 23046.

FORNET, Jorge. Nuevos paradigmas en la narrativa latinoamericana. College Park Working Series, Latin American Studies Center, University of Maryland, n 13, 2005.

FOUCAULT, Michel. Prefacio a la transgresión. In: Entre filosofía y literatura Obras esenciales: volumen 1. Trad. Miguel Morey. Barcelona: Paidós, 1999. p. 163-80.

Lenguaje y Literatura. In: Baquero. Barcelona: Paidós, 1996. p. 63-103.

De lenguaje y literatura. Trad. Isidro Herrera

FRANKEN K., Clemens A. La novela negra argentina y chilena de (pos-)dictadura. Taller de Letras, Santiago de Chile, Pontificia Universidad Católica de Chile, n 49, p. 97-107, 2011.

FUENTES, Carlos. O romance morreu? In: Geografia do romance. Trad. Carlos

Nougué. Rio de Janeiro: Rocco, 2007. p. 9-33. 
FURTADO, Marli Terezinha. Bertolt Brecht e o teatro épico. Revista Fragmentos, Florianópolis, Universidade Federal de Santa Catarina, vol. 5, ${ }^{\circ} 1$ 1, 1995. Disponível em: <https://periodicos.ufsc.br/index.php/fragmentos/article/view/4826>. Acesso em: $11 \mathrm{abr}$. 2014.

GANDOLFO, Elvio E. El libro de los géneros. Buenos Aires: Norma, 2007. 328 p.

GARCÍA BERRÍO, Antonio y HERNÁNDEZ FERNÁNDEZ, Teresa. La poética: tradición y modernidad. Madrid: Síntesis, 1994. 174 p.

GIARDINELLI, Mempo. La novela policial y detectivesca en América Latina: coincidencias, divergencias e influencias de esta literatura norteamericana del siglo veinte con la literatura latinoamericana. In: KLAHN, Norma \& CORRAL, Wilfredo H. Los novelistas como críticos. Tomo II. México: Ediciones del Norte / Fondo de Cultura Económica, 1991. p. 58593.

GINZBURG, Carlo. Sinais: Raízes de um paradigma indiciário. In: Mitos, emblemas, sinais: morfologia e história. 2 ed. Trad. Federico Carotti. São Paulo: Companhia das Letras, 2011. p. 143-79.

Estranhamento: Pré-história de um procedimento literário. In: Olhos de madeira. Nove reflexões sobre a distância. Trad. Eduardo Brandão. São Paulo: Companhia das Letras, 2001. p. 15-41.

GOLDMANN, Lucien. A Criação Cultural na Sociedade Moderna. Trad. João Assis Gomes \& Margarida Sabino Morgado. Lisboa: Presença, 1972. 192 p.

GONÇALVES, Michele C. Dávila. De "Pulp Fiction” a metaficción literaria: las transformaciones del personaje detectivesco en la narrativa policial brasileña. Chasqui, $\mathrm{n}^{\mathrm{o}}$ 34.2, p. 78-91, 2005.

GÓNGORA, Luis de. Soledades. Ed. de John Beverley. 6 ed. Madrid: Cátedra, 1998. 176 p.

GROYS, Boris. Sobre lo nuevo. In: Antología. Trad, Saúl Villa. México: COCOM Press, 2013. p. 9-31.

GUTIÉRREZ GIRALDO, Rafael. Adiós a Macondo: anotaciones sobre narrativa latinoamericana contemporánea. Revista Cuadernos de Literatura, Bogotá, $n^{0} 26$, julio diciembre, 2009.

HABERKORN, Leonardo. De qué hablamos cuando hablamos del Liberaij. Revista Tres, Montevideo, 6 de febrero de 1998. Disponível em: <http://letrasuruguay.espaciolatino.com/haberkorn/liberaij.htm>. Acesso em: 24 mar. 2014.

HAINING, Meter (comp.). Introdução. In: Noir americano: uma antologia do crime de Chandler a Tarantino. Trad. Ronaldo Sergio de Biasi. 2 ed. Rio de Janeiro: Record, 1998. p. 7-11.

HAMBURGER, Käte. Lógica da criação literária. 2.ed. Trad. Margot P. Malnic. São Paulo: Perspectiva, 1986. 260 p.

HERNÁNDEZ, José. Martín Fierro. 2. ed. Buenos Aires: Losada, 2002. 350 p. 
HOMERO. A odisseia (em forma de narrativa). 14 ed. Trad e adapt. Fernando C. de Araújo Gomes. Rio de Janeiro: Ediouro, 1996. 270 p.

HUTCHEON, Linda. Poética do pós-modernismo: história, teoría, ficção. Trad. Ricardo Cruz. Rio de Janeiro: Imago, 1991. 330 p.

JAKOBSON, Roman. Do realismo artístico. In: EIKHENBAUM, Boris et alii. Teoria da literatura: formalistas russos. Trad. Ana Mariza Ribeiro e outros. Porto Alegre: Ed. Globo, 1971. p. 119-27.

JEHA, Julio. Literatura criminal: uma narrativa da violência urbana. Contracorrente: revista de estudos literários, Manaus: Universidade do Estado do Amazonas, v. 2, n 2, "Narrativas da Violência", p. 89-101, 2011.

JUMA (Julio César Martínez). El fin de los hampones, acribillados y maldecidos por la multitud enardecida. La red 21. Montevideo, 12 de diciembre de 2004a. Disponível em: $<$ http://www.lr21.com.uy/justicia/162410-el-fin-de-los-hampones-acribillados-y-maldecidospor-la-multitud-enardecida>. Acesso em: 24 mar. 2014.

Unas 100 mil personas rodeaban el escenario del bestial enfrentamiento. La red 21. Montevideo, 05 de diciembre de 2004b. Disponível em:

$<$ http://www.lr21.com.uy/justicia/161741-unas-100-mil-personas-rodeaban-el-escenario-delbestial-enfrentamiento>. Acesso em: 24 mar. 2014.

En medio de un infierno de sangre y pólvora, cayeron en su ley: el gatillo. La red 21. Montevideo, 28 de noviembre de 2004c. Disponível em:

$<$ http://www.lr21.com.uy/justicia/161064-en-medio-de-un-infierno-de-sangre-y-polvoracayeron-en-su-ley-el-gatillo>. Acesso em: 24 mar. 2014.

KLINGER, Diana. A arte murmurada ao redor do fogo (Um mapa possível da narrativa latino-americana presente). Revista Grumo, Buenos Aires / Rio de Janeiro, $n^{\circ}$ 7, p. 12-9, diciembre, 2008.

LADDAGA, Reinaldo. Espectáculos de realidad: ensayo sobre la narrativa latinoamericana de las últimas dos décadas. Rosario: Beatriz Viterbo, 2007.

LAFFORGUE,Jorge \& RIVERA, Jorge B. Asesinos de papel: ensayos sobre narrativa policial. Buenos Aires: Ediciones Colihue, 1996.

LINK, Daniel (comp.). El juego de los cautos. Literatura policial: de Edgar A. Poe a P.D. James. Colección cuadernillos de géneros. Buenos Aires: La Marca, 2003. 184 p. 2002. 269 p.

Como se lê e outras intervenções críticas. Trad. Jorge Wolf. Chapecó: Argos,

Rodolfo Walsh y la crisis de la literatura. In: ANTELO, Raúl et alii (org.). Declínio da arte / Ascensão da cultura. Florianópolis: Letras Contemporâneas / ABRALIC, 1998. p. 135-44.

LUDMER, Josefina. Literaturas postautónomas 2.0. Revista Z Cultural, Rio de Janeiro, UFRJ, ano IV, $\mathrm{n}^{\circ} 1,2011$. 
1988. $321 \mathrm{p}$.

El género gauchesco: un tratado sobre la patria. Buenos Aires: Sudamericana,

LUKÁCS, Georg. A teoria do romance. 2. ed. Trad. José Marcos Mariani de Macedo. São Paulo: Duas Cidades / Ed. 34, 2009. 174 p.

LUNA, Félix. Breve historia de los argentinos. 11. ed. Buenos Aires: Planeta, 2003. 280 p.

MANDEL, Ernest. Delícias do crime: história social do romance policial. Trad. Nilton

Goldmann. São Paulo: Busca Vida, 1988. 222 p.

MARÍAS, Javier. Corazón tan blanco. Barcelona: Debolsillo, 2010. 318 p.

MASSI, Fernanda. O romance policial do século XXI: manutenção, transgressão e inovação do gênero. São Paulo: Cultura Acadêmica, 2011. 169 p.

MENDILOW, Adam Abraham. Convenções formais; Convenções mediais. In: $\mathbf{O}$ tempo e o romance. Trad. Flávio Wolf. Porto Alegre: Globo, 1972. p. 51-6; 56-8

MILLER, Arthur. Tragedy and the Common Man. In: Arthur Miller. New York: Viking Press, 1978. p. 3-7. The Theater Essays of

MINELLI, María Alejandra. Ficciones literarias y subjetividad. In: (comp.) Cultura y subjetividad en la Argentina finisecular. Córdoba: Alción, 2008. p. 139-53.

MONTEIRO, Paulo Filipe. As artes: várias vidas, várias mortes. In: ANTELO, Raúl et alii (org.). Declínio da arte / Ascensão da cultura. Florianópolis: Letras Contemporâneas / ABRALIC, 1998. p. 135-44.

MORETTI, Franco. Pistas. In: . Signos e estilos da modernidade: ensaios sobre a sociologia das formas literárias. Trad. Maria Beatriz de Medina. Rio de Janeiro: Civilização Brasileira, 2007. p. 155-84.

PECHMAN, Robert Moses. Os excluídos da rua: ordem urbana e cultura popular. In: BRESCIANI, Maria Stella (org.). Imagens da cidade. Séculos XIX e XX. São Paulo: Anpuh/Marco Zero, 1993. p. 29-34.

PELLICER, Rosa. El cadáver vuelve a la biblioteca: El género policíaco en la Argentina a partir de 1990. Aleph, n ${ }^{\circ} 22$, p. 7-23, diciembre de 2007.

PERRONE-MOISÉS, Leyla. A literatura exigente. Folha de São Paulo, São Paulo, 25 de março de 2012, Ilustríssima. Disponível em: <

http://www1.folha.uol.com.br/fsp/ilustrissima/33216-a-literatura-exigente.shtml>. Acesso em: $10 / 05 / 2014$.

PICABEA, María Luján. ¿Qué define al policial argentino? Clarín, Buenos Aires, 15 de junho de 2012. $\tilde{N}$ - Revista de Cultura. Disponível em: < http://www.revistaenie.clarin.com/literatura/Policial-argentino-De-Santis-MartinezLafforgue-Battista_0_719328263.html>. Acesso em: 13/05/2014.

PINTO, Júlio Pimentel. A leitura e seus lugares. São Paulo: Estação Liberdade, 2004. 184 p. 
PITOL, Sergio. El mago de Viena. In: El arte de la fuga. Barcelona: Anagrama. 2007. p. 451-81.

PRIETO, Martín. Breve historia de la literatura argentina. Buenos Aires: Taurus, 2006. $552 \mathrm{p}$.

RIVERS, Elías L. (ed). Poesía lírica del Siglo de Oro. Madrid: Cátedra, 1997. 368 p.

ROBBE-GRILLET, Alain. Projeto para uma revolução em Nova Iorque. Trad. Lausimar Laus. Introd. Affonso Romano de Sant'Anna. Rio de Janeiro: Editora Americana, 1974. 144 p.

ROMERO, Luis Alberto. História contemporânea da Argentina. Trad. Edmundo Barreiros. Rio de Janeiro: Jorge Zahar Ed, 2006. 310 p.

ROSENFELD, Anatol. Reflexões sobre o romance moderno. In: Texto / Contexto I. 5 ed. São Paulo: Perspectiva, 2006. p. 75-97.

RUD, Manuel. Breve historia de una apropiación: apuntes para una aproximación al género policial en la Argentina. Espéculo. Revista de estudios literarios, Madrid, Universidad Complutense, año VII, no 17, marzo-junio 2001. Disponível em: < http://pendientedemigracion.ucm.es/info/especulo/numero17/apropia.html >. Acesso em: 13/05/2014.

SANTIAGO, Silviano. O entre-lugar do discurso latino-americano. In: Uma literatura nos trópicos: ensaios sobre dependência cultural. 2. ed. Rio de Janeiro: Rocco, 2000. p. 9-26. 89-98, março, 1994.

. Literatura e cultura de massa. Novos Estudos, CEBRAP, São Paulo, nº 38, p.

SANTIS, Pablo de. El crimen como enigma de la razón. Clarín, Buenos Aires, 24 de abril de 2010. N - Revista de Cultura. Disponível em: < http://edant.revistaenie.clarin.com/notas/2010/04/24/_-02186615.htm>. Acesso em: $10 / 05 / 2014$.

SARLO, Beatriz. Borges, un escritor en las orillas. Buenos Aires: Ariel, 1995. Disponível em: Borges Studies Online. J. L. Borges Center for Studies \& Documentation. <http://www.borges.pitt.edu/bsol/bse0.htm>. Acesso em: 21 jul. 2014.

Política, ideología y figuración literaria. In: BALDERSTON, Daniel et al. Ficción y política: La narrativa argentina durante el proceso militar. Buenos Aires: Alianza Editorial / Minneapolis: Institute for the Study of Ideologies \& Literature, University of Minnesota, 1987. p. 30-59.

SARLO, Beatriz \& SCHWARZ, Roberto. Literatura y valor. In: ANTELO, Raúl et alii (org.). Leituras do Ciclo. Florianópolis: ABRALIC; Chapecó: Grifos, 1999. p. 287-306.

SARMIENTO, Domingo F. Facundo - Civilización y barbarie. 12. ed. Buenos Aires: Losada, 2002. 306 p. 
SCHWARTZ, Adriano. A estratégia do crime. Folha de São Paulo, São Paulo, 08 fev. 2004. Caderno Mais!, p. 7-9.

SEMILLA DURÁN, María A. Variaciones y recurrencias: El eterno retorno del mito de la cautiva en la literatura argentina. In: FLETCHER, Lea (comp.). Mujeres y cultura en la Argentina del siglo XIX. Buenos Aires: Feminaria, 1994.

SISCAR, Marcos. Apresentação; O discurso da crise e a democracia por vir. In:

Poesia e crise: ensaios sobre a "crise da poesia" como topos da modernidade. Campinas: Editora da Unicamp, 2010. p. 9-13; 17-40.

SPERANZA, Graciela. Autobiografía, crítica y ficción: Juan José Saer y Ricardo Piglia. Boletín del Centro de Estudios de Teoría y Crítica Literaria, Rosario, nº 9, p. 90-103, diciembre, 2001.

STORCH, Robert D. O policiamento do cotidiano na cidade vitoriana. Cultura \& Cidades. Revista Brasileira de História, São Paulo, Anpuh/Marco Zero, v. 5, n 8-9. p. 7-33, 1985.

SZONDI. Peter. Ensaio sobre o trágico. Trad. Pedro Süssekind. Rio de Janeiro: Zahar, 2004. $154 \mathrm{p}$.

TODOROV, Tzvetan. Tipologia do romance policial. In: Poética da prosa. Trad. Claudia Berliner. São Paulo: Martins Fontes, 2003a. p. 63-77.

As estruturas narrativas. 4. ed. Trad. Leyla Perrone-Moisés. São Paulo:

Perspectiva, 2003b. 202 p.

El origen de los géneros. Trad. Antonio Fernández Ferrer. In: GARRIDO

GALLARDO, Miguel Ángel. Teoría de los géneros literários. Madrid: Arco Libros, 1998.

Os géneros do discurso. Lisboa: Edições 70, 1981.

$122 \mathrm{p}$.

Estruturalismo e poética. 2. ed. Trad. José Paulo Paes. São Paulo: Cultrix, 1971.

TOMACHEVSKI, Boris. Temática. In: EIKHENBAUM, Boris et alii. Teoria da literatura: formalistas russos. Trad. Ana Mariza Ribeiro e outros. Porto Alegre: Ed. Globo, 1971. p. 169204.

TYNIANOV, Yuri. Da evolução literária. In: EIKHENBAUM, Boris et alii. Teoria da literatura: formalistas russos. Trad. Ana Mariza Ribeiro e outros. Porto Alegre: Ed. Globo, 1971. p. 105-18.

VECCHI, Roberto. Restos indissolúveis da crueldade: considerações sobre violência, mal e escrita literária. Contracorrente: revista de estudos literários, Manaus, Universidade do Estado do Amazonas, v. 2, n 2, "Narrativas da Violência", p. 173-86, 2011.

VILA-MATAS, Enrique. Historia abreviada de la literatura portátil. 6 ed. Barcelona: Anagrama, 2011. $126 \mathrm{p}$.

VIÑAS, David. El escritor liberal romántico. In: De Sarmiento a Cortázar: literatura argentina y realidad política. Buenos Aires: Ed. Siglo Veinte, 1974. p. 13-20. 
VOLPI, Jorge. Mentiras contagiosas. Madrid: Páginas de Espuma, 2008. 255 p.

WALSH, Rodolfo. Dois mil e quinhentos anos de literatura policial. In: . Variaciões em vermelho e outros casos de Daniel Hernández. Trad. e posfácio Sérgio Molina e Rubia Prates Goldoni. São Paulo: Editora 34, 2011. p. 221-5.

Esa mujer. In: Esa mujer. Los oficios terrestres. Buenos Aires: Ediciones de la Flor, 2001. p. 9-19.

WEINHARDT, Marilene. Quando a história literária vira ficção. In: ANTELO, Raúl et alii (org.). Declínio da arte / Ascensão da cultura. Florianópolis: Letras Contemporâneas / ABRALIC, 1998. p. 103-9.

WILSON, Edmund. Why do people reads detective stories?; Who cares who killed Roger Ackroyd?; Mr. Holmes, They Were the Footprints of a Gigantic Hound!. In: Classics and Comerciais. A Uterary Chronicle of the Forties. Nova York: Farrar, Strauss and Company, 1950. p. 231-237; 257-274.

\section{Sites consultados}

http://houaiss.uol.com.br/

http://www.rae.es/recursos/diccionarios/drae

http://www.bcra.gov.ar/ 